MANUELA DA PALMA COELHO GERMANO LOURENÇÃO

\title{
O PRINCÍPIO DA CONGRUÊNCIA NO PROCESSO INDIVIDUAL DO TRABALHO
}

\author{
DISSERTAÇÃO DE MESTRADO
}

Orientador: Professor Aposentado Cássio de Mesquita Barros Junior

FACULDADE DE DIREITO DA UNIVERSIDADE DE SÃO PAULO SÃO PAULO 


\title{
O PRINCÍPIO DA CONGRUÊNCIA NO PROCESSO INDIVIDUAL DO TRABALHO
}

\author{
Dissertação apresentada à Faculdade de Direito \\ da Universidade de São Paulo para obtenção do \\ título de Mestre em Direito. \\ Área de Concentração: Direito do Trabalho e \\ Seguridade Social \\ Orientador: Professor Aposentado Cássio de \\ Mesquita Barros Junior
}

FACULDADE DE DIREITO DA UNIVERSIDADE DE SÃO PAULO

SÃO PAULO 


\section{O PRINCÍPIO DA CONGRUÊNCIA NO PROCESSO INDIVIDUAL DO TRABALHO}

Dissertação apresentada à Faculdade de Direito da Universidade de São Paulo para obtenção do título de Mestre em Direito.

Área de Concentração: Direito do Trabalho e Seguridade Social

Orientador: Professor Aposentado Cássio de Mesquita Barros Junior

Aprovada em:

BANCA EXAMINADORA

Prof.

Instituição:

Julgamento: Assinatura:

Prof.

Instituição:

Julgamento: Assinatura:

Prof.

Instituição:

Julgamento: Assinatura: 
Aos meus amigos da

Liga Trabalhista do DJ XI de Agosto. 


\section{AGRADECIMENTOS}

À minha amada família, Papi, Mami e Xuxuca;

A meus queridíssimos amigos de Mestrado e de dúvidas trabalhistas, Aninha e Luís, pela troca de experiências e conselhos nestes últimos três anos de estudos;

A Evorah e um jantar no Palermo Soho que rendeu o Capítulo 4 desta dissertação;

A Paola Poma, minha eterna professora;

Ao Thiago, pela paciência com a sócia por vezes ausente; e

Ao Calouro, cuja ajuda foi grande demais para ser descrita nestas poucas linhas.

Agradeço ainda ao meu orientador, Professor Cássio de Mesquita Barros, e aos membros da minha banca de qualificação, Professores Paulo Eduardo Vieira de Oliveira e Homero Batista Mateus da Silva, pelas preciosas observações e sugestões. 
Como pois interpretar, o que os heróis não contam?

Como vencer o oceano, se é livre a navegação, mas proibido fazer barcos?

Carlos Drummond de Andrade 


\section{RESUMO}

A presente dissertação tem por objetivo o estudo da aplicação do princípio da congruência no Processo Individual do Trabalho. Tal princípio caracteriza-se pelo caráter restritivo da atuação judicial, vinculando a prolação de sentença aos limites da lide. A problemática centra-se no entendimento do conceito de lide, ora entendido simplesmente como pedido, ora como a matéria fática e jurídica levada aos autos, permitindo-se ao magistrado conhecer de pedidos não formulados expressamente, desde que os fatos a eles pertinentes tenham sido discutidos nos autos. A partir da Teoria Instrumentalista do Processo, que admite este modo de resolução de conflitos como um meio para a efetividade do Direito Material, buscou-se identificar a possibilidade de flexibilização do princípio da congruência no Processo Individual do Trabalho, tendo em vista que o estudo deste princípio revelou que a doutrina e a jurisprudência civil e trabalhista já permitem sua relativização ou mitigação em determinados casos, em especial quando se trata da aplicação de norma de ordem pública, uma das características do Direito Material do Trabalho. Ademais, considerando as questões linguísticas implicadas na formulação da pretensão da parte e da sentença, foi feita pesquisa jurisprudencial no sítio eletrônico do Tribunal Superior do Trabalho, de modo a identificar as relações hermenêuticas estabelecidas entre o pedido e a decisão final neste tribunal. Para tanto, foram selecionadas 149 decisões em que se discute a existência ou não de julgamento além dos limites da lide, destacando-se os casos em que o tribunal considerou desnecessária a formulação de pedido expresso para a concessão de direito trabalhista.

Palavras-chave: Direito do Trabalho, Processo do Trabalho, Princípios, Congruência, Vinculação, Sentença, Petição Inicial, Contestação, Pedido, Lide, Limites, Poder do Juiz, Jurisprudência. 


\begin{abstract}
The purpose of this dissertation is to study the use of the Principle of Ne Ultra et Extra Petita in individual labor process. This principle is defined by the restrictive aspect of the acts of the judge, binding the sentence to the matters under dispute. The core discussion lies on the identification of such matters, which can be seen as simply the pleadings expressed by the parties or as all the matters in connection with the facts merely mentioned by them. The latter position would allow the judicial authority to pronounce a sentence addressing additional matters that were not expressly pleaded by the parties. Based on the idea that the due process of law is an instrument to achieve effectiveness of legal commands, on the already accepted exception of this principle when it comes to public order rules, and also on the assumption that labor law is of public order, this dissertation analyzed the possibility of disregarding the Principle of Ne Ultra et Extra Petita in individual labor process in order to enhance the legal award. In addition to the theoretical analysis, a wide research on the website of the superior labor court (Tribunal Superior do Trabalho) was carried out in order to verify the hermeneutical relations between the pleadings and the dispositions of the judicial decision. Bearing such an objective in mind, 149 decisions on the alleged violation of the Principle of Ne Ultra et Extra Petita were selected and analyzed, focusing on those awards in which the court considered irrelevant the existence of an express pleading in order to grant or deny a specific labor right.
\end{abstract}

Keywords: Labour Law, Labour Legal Proceedings, Principles of Law, Principle of Ne Ultra et Extra Petita, Entailment, Judgement, Plaintiff's Complaint, Defendant's Answer, Plea, Suit, Limit, Power of the Judge, Case Law. 


\section{LISTA DE SIGLAS}

CF - Constituição Federal

CIPA - Comissão Interna de Prevenção de Acidentes

CLT - Consolidação das Leis do Trabalho

CNJ - Conselho Nacional de Justiça

CPC - Código de Processo Civil

CTPS - Carteira de Trabalho e Previdência Social

FGTS - Fundo de Garantia do Tempo de Serviço

LICC - Lei de Introdução ao Código Civil

OIT - Organização Internacional do Trabalho

PDV - Programa de Demissão Voluntária

RR - Recurso de Revista

SDI - Seção Especializada em Dissídios Individuais

TRCT - Termo de Rescisão de Contrato de Trabalho

TRT - Tribunal Regional do Trabalho

TST - Tribunal Superior do Trabalho 


\section{LISTA DE GRÁFICOS}

Gráfico 1 - Decisões da SDI - 1: Decisões Ultra e Extra Petita .................................... 104

Gráfico 2 - Decisões da SDI - 2: Decisões Ultra e Extra Petita .................................... 104

Gráfico 3 - Assunto: Direito Material x Direito Processual ......................................... 105

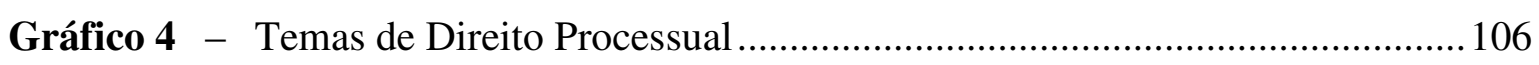

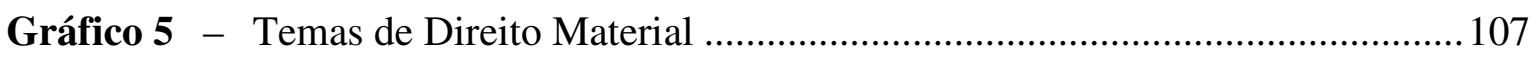

Gráfico 6 - Existência de pedido e causa de pedir ........................................................ 108

Gráfico 7 - Posição do TST quando não há pedido expresso ou o pedido é irrelevante ... 108

Gráfico 8 - Posição do TST quando há pedido, mas não há o fundamento adotado .... 109

Gráfico 9 - Fundamentos para manutenção da decisão (pedido).................................. 110

Gráfico 10 - Fundamentos para reforma da decisão (pedido) ....................................... 110

Gráfico 11 - Fundamentos para manutenção da decisão (causa de pedir) .......................111

Gráfico 12 - Fundamentos para reforma da decisão (causa de pedir) .............................111 


\section{SUMÁRIO}

1 CONSIDERAÇÕES HISTÓRICAS SOBRE O DIREITO MATERIAL E

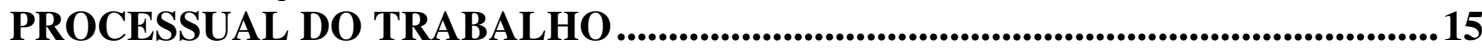

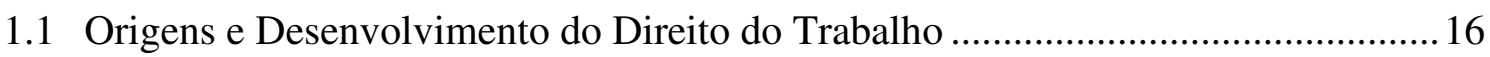

1.2 Direito Material e Processual do Trabalho no Brasil .................................................. 18

2 PROCESSO E RESOLUÇÃO DO CONFLITO_..................................................25

2.1 Conflito Social e Conflito Jurídico: o Papel do Pedido no Processo .........................25

2.2 Resolução do Conflito Jurídico: Escopos do Processo e Efetividade da Norma .....29

2.3 O Problema Atual da Efetividade dos Direitos Trabalhistas ...................................32

2.3.1 Efetividade e Irrenunciabilidade da Norma Trabalhista ...................................32

2.3.2 O Papel do Estado no Cumprimento das Normas Trabalhistas ..........................34

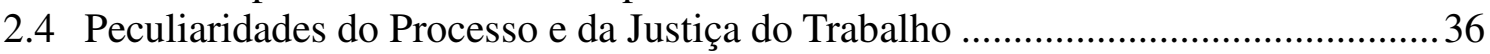

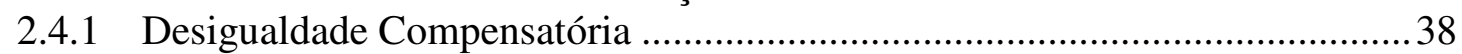

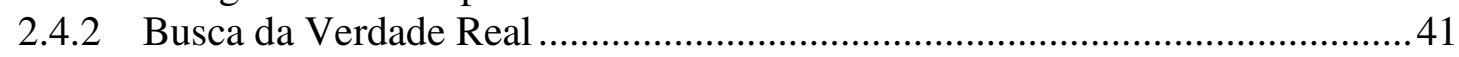

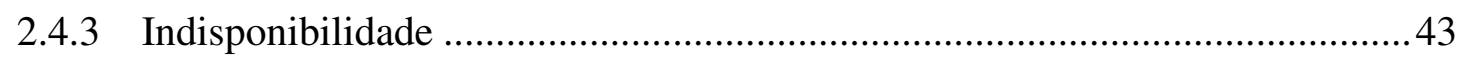

3 PRINCÍPIO DA CONGRUÊNCIA .......................................................................46

3.1 Questões Preliminares....................................................................................... 46

3.2 O Princípio da Congruência e sua Relação com Outros Princípios.........................51

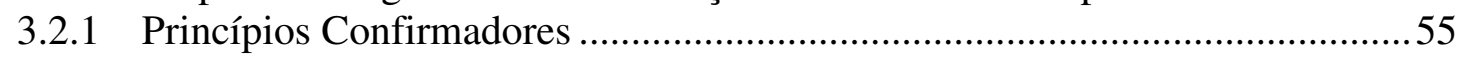

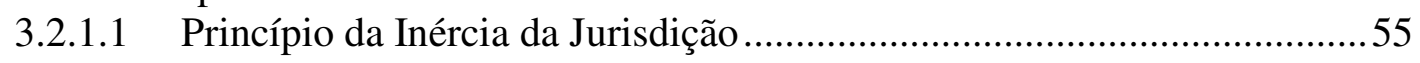

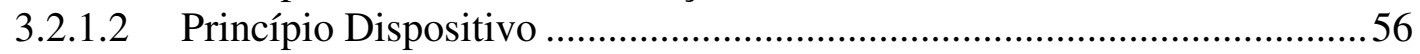

3.2.1.3 Princípio do Contraditório .................................................................5 57

3.2.1.4 Princípio da Isonomia e Princípio da Imparcialidade do Juiz .................58

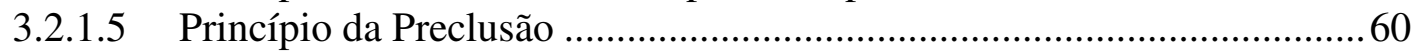

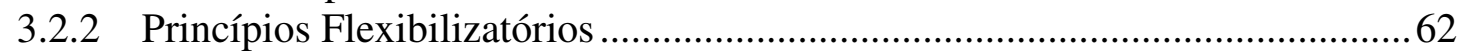

3.2.2.1 Princípio do Iura Novit Curia e do Da Mihi Factum, Dabo Tibi Ius .......62

3.2.2.2 Princípio do Indeclinabilidade do Julgamento..........................................6 64

3.2.2.3 Princípio da Economia Processual.........................................................65

3.2.2.4 Princípio do Livre Convencimento do Juiz ..............................................66 66

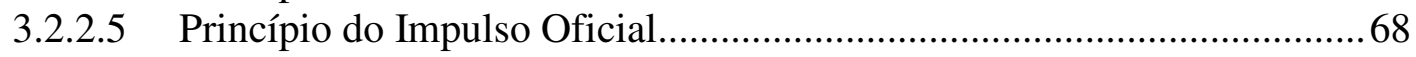

3.3 Petição Inicial e Respostas do Réu: seus Papéis na Delimitação da Lide ...............69

3.3.1 Requisitos da Petição Inicial e a Congruência ................................................ 70

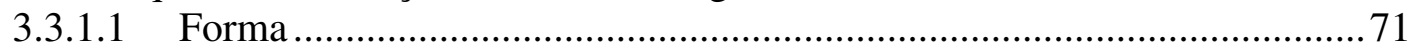

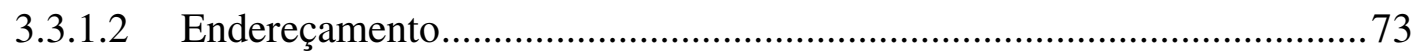

3.3.1.3 Qualificação das Partes ...................................................................... 73

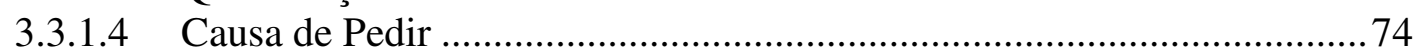

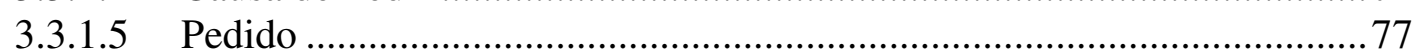

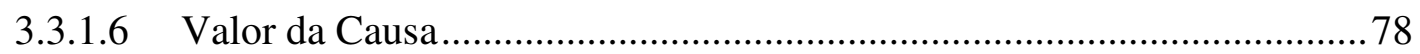

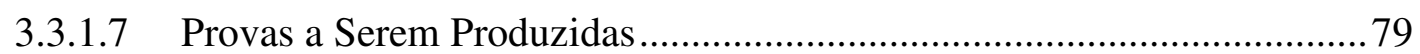

3.3.1.8 Requerimento de Citação do Réu .......................................................... 80

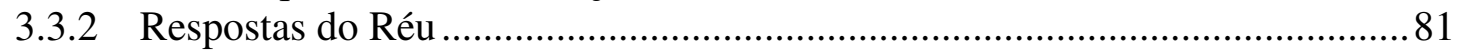

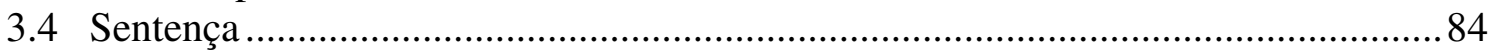

3.4.1 Das Sentenças Citra, Ultra e Extra Petita .................................................... 86 


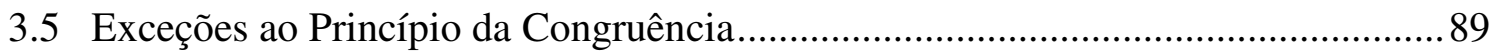

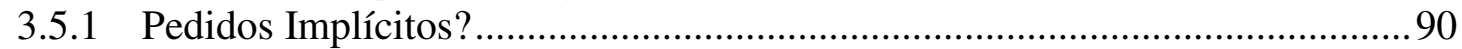

3.5.2 Exceções Legais e Jurisprudenciais ao Princípio da Congruência .................. 92

3.5.2.1 Medidas Cautelares ............................................................................. 92

3.5.2.2 Prestações Vencidas no Curso do Processo ............................................. 93

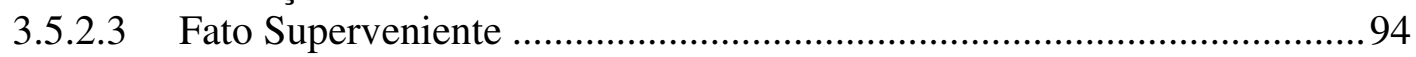

3.5.2.5 Correção Monetária e Juros ................................................................ 95

3.5.2.6 Custas Processuais e Tutela das Obrigações de Fazer/Não Fazer ............96

3.5.2.7 Multa por Litigância de Má-Fé Processual .............................................. 96

3.5.2.8 Anotação em Carteira de Trabalho e Previdência Social e Declaração de Vínculo Empregatício....................................................................... 98

3.5.2.9 Indenização do Empregado Estável ......................................................99

3.5.2.10 Contribuições Previdenciárias ................................................................. 100

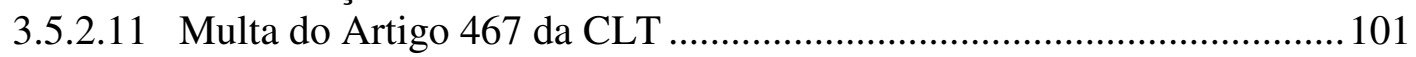

4 APLICAÇÃO DO PRINCÍPIO DA CONGRUÊNCIA NO TRIBUNAL SUPERIOR DO TRABALHO: UMA ANÁLISE JURISPRUDENCIAL ...........102

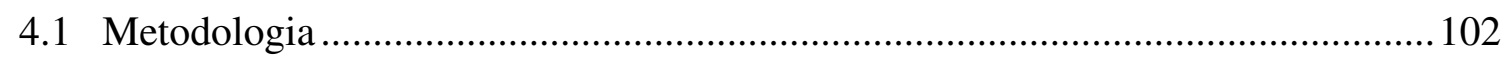

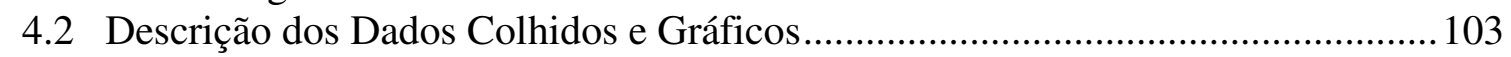

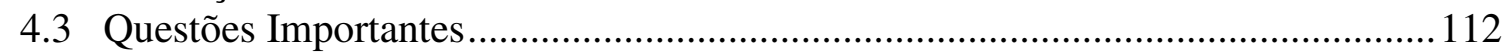

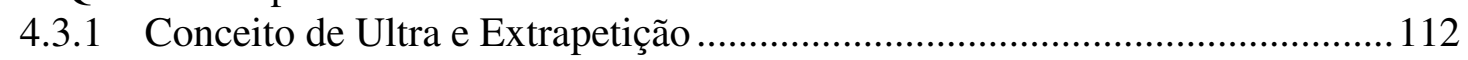

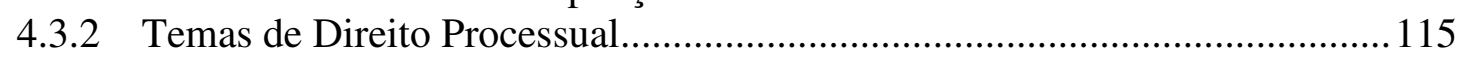

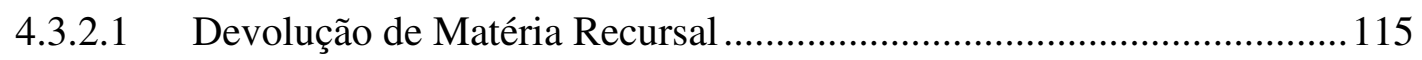

4.3.2.2 Liquidação da Sentença ....................................................................... 116

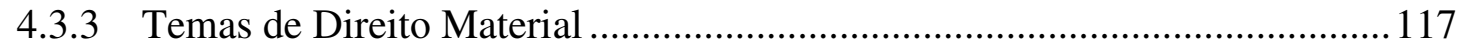

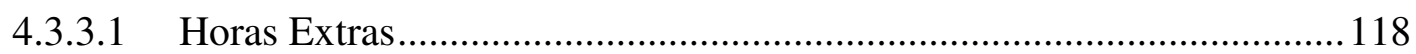

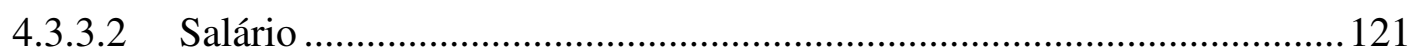

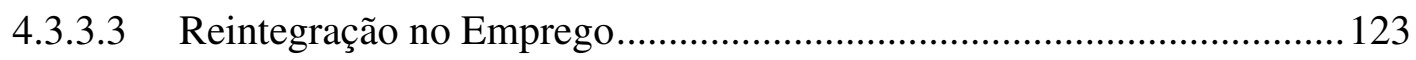

4.3.3.4 Responsabilidade Solidária e Subsidiária ............................................. 125

4.3.3.5 Contrato de Trabalho com a Administração Pública ............................. 127

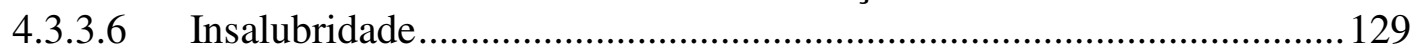

4.3.3.7 Reconhecimento de Vínculo Empregatício e Anotação em CTPS ........ 131

4.3.4 Flexibilização do Princípio da Congruência em Relação ao Pedido e à Causa

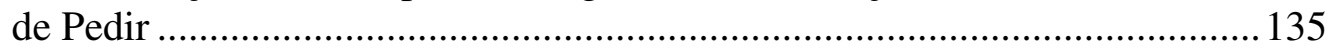

4.3.4.1 Iura Novit Curia ou Da Mihi Factum, Dabo Tibi Ius........................... 135

4.3.4.2 Decorrência Lógica do Pedido................................................................. 137

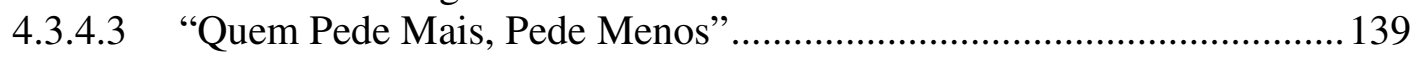

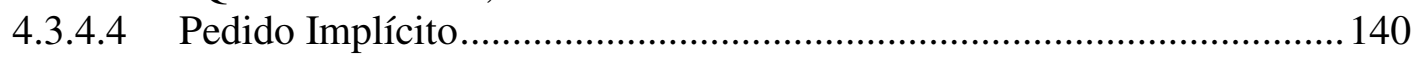

4.3.4.5 Livre Convencimento do Juiz .............................................................. 140

4.3.4.6 Simplicidade do Processo do Trabalho................................................... 141

4.3.4.7 Norma de Ordem Pública .................................................................. 143

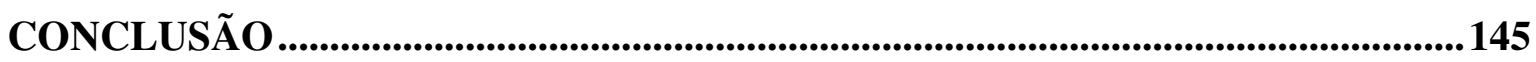

REFERÊNCIAS BIBLIOGRÁFICAS.........................................................................148

ANEXO 1 - MODELO DE FICHAMENTO .......................................................157

ANEXO 2 - LISTA DE PROCESSOS..................................................................159 


\section{INTRODUÇÃO}

O tema desta dissertação é a utilização do princípio da congruência - ou princípio da adstrição ao pedido - no Processo do Trabalho. Tal princípio, em linhas gerais, é uma limitação ao poder do juiz, que deve ficar adstrito ao pleiteado na petição inicial quando do proferimento da sentença: não pode conceder nada que vá além ou que seja diferente do pedido. Trata-se de preceito ligado ao princípio dispositivo e ao respeito ao contraditório, como garantia de previsibilidade do resultado. Não obstante, a legislação contém previsões expressas do afastamento dessa limitação e a jurisprudência vem admitindo a existência de pedidos implícitos, a possibilidade de interpretação do pedido, e, principalmente, o conhecimento, de ofício pelo juiz, de matéria de ordem pública, de modo a tornar efetiva a tutela judicial.

A escolha deste tema deu-se com base na experiência adquirida no Departamento Jurídico XI de Agosto, com a criação da Liga Trabalhista, um grupo de alunos da Faculdade de Direito da Universidade de São Paulo que pretendia atender parte da demanda trabalhista da população carente de São Paulo. A ineficiência da Defensoria Pública da União e a crise de representatividade dos sindicatos foram identificadas como os motivos que levaram a Delegacia Regional do Trabalho a fornecer o endereço do DJ XI de Agosto, com referência expressa aos dias de atendimento da Liga Trabalhista, aos trabalhadores que os procuravam. Ou seja, durante sua existência, a Liga Trabalhista passou a ser considerada referência desse tipo de atendimento, o que a levava a atender até 15 casos por dia. Não havia, decerto, estrutura física, pessoal e profissional para dar conta de todos os casos que chegavam ao DJ XI de Agosto e por isso os clientes, após uma detalhada orientação, passaram a ser encaminhados ao setor de Reclamação Verbal da Justiça do Trabalho para que, posteriormente, retornassem com a data da audiência já definida, de modo que nessa ocasião fossem acompanhados por advogado. Apesar dos esforços para a prestação de um serviço de qualidade, era inevitável que houvesse falhas na elaboração da petição inicial e a relação entre a indisponibilidade dos direitos trabalhistas, o efetivo acesso à justiça e os limites da sentença se apresentaram como uma questão intrigante. 
Ao mesmo tempo, um breve estudo da jurisprudência cível e trabalhista revelava a existência de decisões que rejeitavam uma interpretação literal do pedido, permitindo ao juiz inferir pedidos implícitos e logicamente decorrentes dos explicitamente formulados na inicial, de modo a quebrar com a concepção silogística da elaboração da sentença e a flexibilizar a regra de vinculação do juiz ao pedido.

Assim, considerando-se que este trabalho versa sobre um poder do juiz, que é, em última instância, uma modalidade de intervenção estatal, a questão analisada no primeiro capítulo é a pertinência dessa intervenção (de sua continuidade e até mesmo de sua ampliação) em face das peculiaridades históricas das relações de trabalho no Brasil: de um lado, a necessidade de proteção nas relações individuais; de outro, o almejo pela efetiva mobilização laboral por meio dos sindicatos e também pela prevalência da autonomia da vontade coletiva.

O segundo capítulo aborda o papel do processo na resolução dos conflitos, em geral; em seguida, focando no Processo Trabalhista, registra-se como seus princípios específicos contribuem para dar maior efetividade aos direitos trabalhistas, os quais, embora constitucionalmente indisponíveis, têm um índice de descumprimento característico.

No terceiro capítulo, trata-se especificamente do princípio da congruência, com ênfase ao seu conceito, à sua justificativa no ordenamento atual, às suas exceções legais, doutrinárias e jurisprudenciais e à pertinência de seu afastamento para um Processo Trabalhista efetivo, tanto na fase de conhecimento quanto na fase de execução. Como se verá, a ausência de tratamento do referido princípio na legislação processual trabalhista somada à consequente escassa doutrina sobre o assunto - acarreta a referência constante à doutrina civilista, com as devidas ressalvas. Adicionalmente, é feita uma breve abordagem da questão linguística que envolve a ideia de princípios implícitos, decorrência lógica do pedido e julgamento ultra e extra petita, de modo a determinar se realmente se trata de situações diferentes. Esclarece-se, desde já, que o julgamento citra petita foi abordado apenas incidentalmente neste trabalho, não tendo sido sequer objeto da pesquisa jurisprudencial, tendo em vista que a problemática da citra petição relaciona-se com a omissão do juiz, enquanto a da ultra e extrapetição, a uma ação judicial "excessiva". Assim, da perspectiva do cumprimento integral da norma material e do processo efetivo, o julgamento citra petita é indefensável, posto que viola o princípio do acesso ao Judiciário e da indeclinabilidade de jurisdição, enquanto que os julgamentos ultra e extra petita, em determinados casos, pode ter um efeito social e jurídico positivo. 
Por fim, o levantamento e a análise das decisões sobre o princípio da congruência no TST em relação ao uso do princípio da congruência no Judiciário Trabalhista permitiu a elaboração de sugestão - não apenas doutrinariamente embasada, mas também jurisprudencialmente - relativa à manutenção ou repúdio desse princípio. O uso da jurisprudência como fonte de pesquisa justifica-se perante o fortalecimento do Judiciário; vide súmulas vinculantes. Além disso, a regulação jurisprudencial do Direito Material e Processual do Trabalho é fato inegável para o operador do Direito: além das súmulas, o TST também edita orientações jurisprudenciais, que são utilizadas como parâmetro para conhecimento de recursos em seu próprio âmbito de atuação. Exemplo último da força da jurisprudência trabalhista é a súmula 331 do TST, o mais conhecido texto "normativo" sobre a terceirização de mão de obra, um fenômeno socioeconômico que transformou as relações de trabalho no Brasil nos últimos vinte anos.

Ademais, uma pesquisa meramente doutrinária levaria à produção de uma dissertação em que seria enorme a distância entre o ser e o dever ser, simplesmente analisando a possibilidade de proferimento de um determinado tipo de decisão judicial (ultra ou extra petita) frente aos consagrados princípios do processo, como a consolidação da instrumentalidade das formas, do direito ao acesso à justiça, do papel atuante do juiz, sem ao menos vislumbrar os problemas práticos que tal possibilidade poderia oferecer. $\mathrm{O}$ tema aqui analisado, como se verá mais adiante, tem natureza inegavelmente prática, pois envolve a interpretação dos pedidos formulados pelas partes e o ser humano é tão criativo que não é possível prever todas as mirabolâncias que um advogado trabalhista pode colocar em uma petição. Apenas a leitura das decisões sobre esse assunto é que pode revelar não apenas como o TST lida com tais questões, mas também como elas são postas pelas partes. Assim, além do sentido acadêmico, pretende-se que esta dissertação tenha também uma função orientadora, no tocante à elaboração das peças processuais, para os que militam perante a Justiça do Trabalho. 


\section{CONSIDERAÇÕES HISTÓRICAS SOBRE}

\section{O DIREITO MATERIAL E PROCESSUAL DO TRABALHO}

Não obstante a doutrina concordar acerca do caráter da formação do Direito, admitindo, inclusive, como modo de interpretação das normas jurídicas o critério histórico ${ }^{1}$, a investigação do Direito segundo essa perspectiva é tratada muitas vezes como mera curiosidade. Não é este o entendimento que se adota nesta dissertação, afinal é especialmente notável a possibilidade de identificar o momento do nascimento do Direito do Trabalho e a sua formação ao longo dos anos, relacionando-os com as transformações no mundo do trabalho.

Ademais, o Direito do Trabalho brasileiro conta com uma peculiaridade, que é a discussão sobre se a nossa legislação trabalhista foi produto de conquista dos trabalhadores ou se foi mera outorga de direitos, como uma benesse estatal, com intenções autoritárias e inspiração mussoliana. Embora tal discussão, numa perspectiva estritamente técnica, não tenha relevância para a aplicação da norma, é inegável que tem impacto sobre a sua legitimidade e, em última instância, sobre o seu caráter disponível ou não, questão crucial na determinação dos instrumentos de Direito Processual a serem utilizados para a resolução de um conflito. Também será dado especial destaque à legislação sindical e à situação dos sindicatos no Brasil, de modo a colher elementos para, levando-se em conta o grau de representatividade e a atuação dos sindicatos no Brasil, avaliar a pertinência do aumento dos poderes dos juízes.

Dessa maneira, buscou-se fazer uma investigação histórica não apenas das origens e do desenvolvimento do Direito Material e Processual do Trabalho, mas também, brevemente, acerca dos movimentos sociais de trabalhadores no Brasil, do seu papel na formação do Direito do Trabalho e da sua relação com a legislação trabalhista pátria, em especial a Consolidação das Leis do Trabalho e a Constituição Federal de 1988, focando, principalmente, nos estudos de John D. French e Maria Celina D'Araújo.

\footnotetext{
${ }^{1}$ Ver SAVIGNY, Friedrich Carl von. Sistema del diritto romano attuale. v. 1. Turim: Unione, 1886. p. 222. $\mathrm{E}$, nos dias de hoje, BARROSO, Luis Roberto. Interpretação e aplicação da Constituição. São Paulo: Saraiva, 2008. p. 132 e ss.
} 


\subsection{Origens e Desenvolvimento do Direito do Trabalho}

O nascimento do Direito do Trabalho é situado, costumeiramente, a partir da Revolução Industrial. Correntes minoritárias, contudo, insistem em observá-lo já nos institutos do Direito Romano, como a locatio de mão de obra, por sua natureza contratual. Ainda que não se possa negar a influência do Direito Romano na formulação da Teoria Geral dos Contratos do Direito Moderno, é um erro situar o nascimento do Direito do Trabalho nessa época, posto que este ramo do Direito é um produto da legislação liberal aliada às reivindicações decorrentes das péssimas condições de vida do proletariado no início da industrialização.

Pode-se identificar uma origem remota do Direito do Trabalho nas corporações, surgidas no século XII, sendo que as subsequentes regulamentações das relações de trabalho diziam respeito à liberdade de contratar: o Código Civil de Napoleão previa a locação de serviços, uma espécie de contrato em que o trabalhador e o empregador estipulavam livremente (em termos formais) as condições de trabalho, o preço e a duração do serviço. Não se tratava propriamente de uma norma trabalhista, tal qual entendida hoje, porém tal disposição legal reflete um aspecto fundamental da relação de trabalho: ser fundada em um contrato, em oposição a outras formas de prestação de serviços, como a escravidão e a servidão.

Embora apenas em 1884 tenha sido reconhecida a personalidade civil aos sindicatos - o que ocorreu na França, muito provavelmente por influência do movimento tradeunionista que se consolidava na Inglaterra desde o começo do século XIX -, a classe operária já se organizava secretamente, organizando operações de sabotagem e, posteriormente, ações grevistas. Para Orlando Gomes, tais movimentos

são a prova evidente de que o impulso inicial dado para o aparecimento do
Direito do Trabalho foi obra do próprio operário, e, não, benevolência de
filantropos, da classe patronal, ou do Estado. Somente a coesão dos integrantes
de uma classe ou categoria profissional ou econômica pode impor reivindicações
ou direitos. A ação direta do proletariado no quadro das condições adversas que
lhe criou a Revolução Industrial foi, pois, o fator principal para a formação
histórica do Direito do Trabalho ${ }^{2}$.

É interessante observar que, enquanto no plano nacional a legislação trabalhista lentamente deixava o campo penal para integrar o patrimônio jurídico dos trabalhadores, no plano internacional os trabalhadores se mobilizavam em movimentos organizados,

\footnotetext{
${ }^{2}$ GOMES, Orlando. Curso elementar de direito do trabalho. São Paulo: Forense, 1963. p. 14.
} 
como a Primeira Internacional, criada em Londres em 1864 com o Manifesto Inaugural de Karl Marx e Friedrich Engels, o Congresso Internacional Operário em 1884, a Conferência de Berlim em 1890, as Conferências de Berna nos anos de 1905, 1906, e 1913 e a Conferência da Paz, que foi instalada no Palácio de Versailles em 1919, após o fim da Primeira Guerra Mundial, e fundou a Organização Internacional do Trabalho (OIT).

Apesar de seu caráter internacionalizante, tais iniciativas tinham por objetivo o incentivo da adoção de legislação social por parte das nações. O principal fruto desses esforços foi, juridicamente, o surgimento do Constitucionalismo Social e, politicamente, a consagração do chamado Estado Social $^{3}$, marcado por sua postura promocional e intervencionista nos campos da economia e da organização do trabalho, em detrimento do modelo anterior de Estado, o qual preconizava a proteção à liberdade individual e à propriedade. Mario Eduardo Martinelli aponta que, na Constituição de Weimar, "o princípio burguês-liberal da plena liberdade de contrato é substituído pelo princípio da intervenção social e estatal no processo econômico, de acordo com os ditames da constituição da economia e do trabalho"4.

A partir das experiências da Segunda Guerra Mundial, em especial a constatação de "que o desconhecimento e o desprezo dos direitos do Homem conduziram a actos de barbárie que revoltam a consciência da Humanidade" ${ }^{\circ}$, foi elaborada a Declaração Universal dos Direitos Humanos da Organização das Nações Unidas. Tal declaração, considerada ainda hoje o principal documento relativo a direitos humanos já produzido, prevê, a partir de seu artigo XXII, os chamados direitos econômicos, sociais e culturais, dispondo explicitamente que todos têm direito ao trabalho em condições justas e favoráveis.

É possível dizer, portanto, que a partir de então, passou a existir uma convergência no tratamento dos direitos sociais nos planos nacional e internacional, tendo sido tais direitos alçados à categoria de direitos fundamentais, implicando uma série de restrições quanto a sua disponibilidade e alienabilidade.

\footnotetext{
${ }^{3}$ Sobre a polêmica instaurada por Carl Schimtt, que nega a existência de um "Estado Social", sustentando que o constituinte de Weimar teria decidido pela manutenção de um modelo burguês de Estado, ver MARTINELLI, Mario Eduardo. A deterioração dos direitos de igualdade material no neoliberalismo. Campinas: Milennium, 2000. p. 97 e ss.

${ }^{4}$ Ibidem, p. 100.

${ }^{5}$ DECLARAÇÃO UNIVERSAL DOS DIREITOS HUMANOS DA ORGANIZAÇÃO DAS NAÇÕES UNIDAS. Preâmbulo. Versão em português disponível em: <http://www.ohchr.org/EN/UDHR/Pages/Language. aspx?LangID=por>. Acesso em: 17 dez. 2010.
} 
Contudo, tal convergência foi momentânea. A partir dos anos 1990, principalmente, houve uma retomada dos ideais do liberalismo, tomando força a tendência para um novo descompasso entre a proteção dos direitos sociais em nível internacional e a verificada em âmbito nacional: enquanto, nos dizeres de Amauri Mascaro Nascimento ${ }^{6}$, a OIT entrou em uma disputa discreta com a Organização Mundial do Comércio - a qual pretende que as questões laborais sejam discutidas sob um viés preponderantemente econômico -, no plano nacional, a legislação trabalhista sofreu severas e rápidas mutações, com o surgimento de novas figuras jurídicas, notadamente flexibilizatórias ${ }^{7}$.

Atualmente, então, o Direito do Trabalho vive um momento de conflito, alternando entre uma concepção protecionista, fortemente marcada pela atuação estatal, e uma tendência reformista, tendente à valorização da autonomia privada coletiva, por meio da ação sindical. Há que se ressaltar, contudo, que a manutenção do Direito do Trabalho como instrumento de proteção social, aliada à concepção flexibilizatória, excluindo, assim, a intervenção estatal nas relações de trabalho, depende de uma criteriosa análise da efetiva capacidade da estrutura sindical para resguardar os interesses dos trabalhadores, sob pena de um verdadeiro retrocesso social e ineficácia de qualquer norma de proteção ao trabalhador.

\subsection{Direito Material e Processual do Trabalho no Brasil}

É vasta a doutrina que estuda o desenvolvimento do Direito Material e Processual do Trabalho no Brasil, não havendo, porém, consenso quanto à sua divisão em etapas históricas. Walküre Lopes Ribeiro da Silva, partindo da classificação de alguns dos principais estudiosos do Direito do Trabalho $^{8}$ e considerando que as divisões por eles propostas tinham em comum "o peso das diretrizes dadas pelas Constituições e a influência das ideologias nos regimes políticos", Direito do Trabalho, que serão adotadas neste estudo.

\footnotetext{
${ }^{6}$ NASCIMENTO, Amauri Mascaro. Curso de Direito do Trabalho. São Paulo: Saraiva, 2006. p. 53.

${ }^{7}$ Ver ANTUNES, Ricardo. Construção e desconstrução da legislação social no Brasil. In: (Org.). Riqueza e miséria do trabalho no Brasil. São Paulo: Boitempo, 2006. p. 14.

${ }^{8}$ Quais sejam: Antonio Ferreira Cesarino Junior, Mozart Victor Russomano, Orlando Gomes, Elson Gottschalk, José Martins Catharino, Evaristo de Moraes Filho, Amauri Mascaro Nascimento e Octavio Bueno Magano. Ver SILVA, Walküre Lopes Ribeiro da. Direito do Trabalho Brasileiro: principais aspectos de sua evolução histórica e as propostas de modernização. Revista do Tribunal Superior do Trabalho, Brasília, v. 69, n. 2, p. 120-138, jul./dez. 2006.

${ }^{9}$ Ibidem, p. 121.
} 
Como já foi visto, o Direito do Trabalho é fruto do liberalismo e liga-se diretamente à liberdade de contratar. Por isso, tem razão José Martins Catharino ${ }^{10}$ ao chamar o período que antecedeu a libertação dos escravos de fase proto-histórica do Direito do Trabalho, sendo que a fase histórica inicia-se apenas quando presentes as condições para o seu surgimento.

Apenas com o advento da Constituição de 1824 é que o trabalho passou a ser objeto de alguma regulamentação, sendo que a principal delas foi o reconhecimento do trabalho livre, a extinção das corporações de ofícios e a garantia dos "socorros públicos".

Porém, a predominância do trabalho escravo tornava a liberdade de contratar inócua: estima-se que, nessa época, havia uma massa escrava no Rio de Janeiro superior a $40 \%$ da população ${ }^{11}$. Não obstante, José Martins Catharino ${ }^{12}$ aponta a promulgação de leis e decretos de cunho trabalhista nesse período, entre os quais merece destaque a Lei $\mathrm{n}^{\mathrm{o}} 108$ de 11 de outubro de $1937^{13}$, que estabeleceu uma regra processual: os conflitos derivados da aplicação dessa lei eram de competência privativa dos Juízes de Paz do foro do tomador de serviços e deveriam ser decididos "summariamente em audiencia geral, sem outra forma regular de processo, que não seja a indispensavelmente necessaria para que as partes possão allegar, e provar em termo breve seu direito" (artigo 14), cabendo recurso para um juiz de Direito.

Por fim, em 13 de maio de 1888, foi promulgada a Lei Áurea, abolindo a escravidão e consagrando o trabalho livre.

Os primeiros proletários brasileiros originavam-se das camadas mais pobres da população urbana e eram, em grande parte, mulheres e crianças. Apesar de já haver, antes da abolição da escravatura, trabalhadores estrangeiros no país (como operários especializados vindos da Inglaterra), o número de imigrantes aumentou consideravelmente a partir de 1888, quando surgiu a necessidade de suprir a mão de obra agrícola, predominantemente escrava até a abolição.

Nota-se, portanto, que a maioria dos imigrantes que chegou a São Paulo até o início do século XX era formada por trabalhadores do campo, vindos, primordialmente, do norte da Itália, com destino às fazendas cafeeiras. Também se pode destacar a vinda em

\footnotetext{
${ }^{10}$ Ver CATHARINO, José Martins. Compêndio de Direito do Trabalho. v. 1. São Paulo: Saraiva, 1981. p. 15.

${ }^{11}$ Ibidem, p. 194.

${ }^{12}$ Ibidem, p. 18 e 19.

${ }^{13}$ BRASIL. Lei $\mathrm{n}^{\circ} 108$ de 11 de outubro de 1837. Dando varias providencias sobre os Contractos de locação de serviços dos Colonos. Coleção das Leis do Império do Brasil. Atos do Poder Legislativo (CLIB-APL). Parte Segunda. Rio de Janeiro: Tipografia Nacional, 1861. p. 39 e 40. Disponível em: $<$ http://www.camara.gov.br/Internet/InfDoc/conteudo/colecoes/Legislacao/Legimp-23/Legimp-23._9.pdf >. Acesso em: 17 dez. 2010.
} 
massa de portugueses, espanhóis e japoneses no período que vai de 1887 a 1930. Boris Fausto aponta justamente a presença dessa mão de obra estrangeira agrícola como um dos fatores de impulso à urbanização da capital do Estado de São Paulo:

a razão principal desse salto [de urbanização] se encontra no afluxo de imigrantes espontâneos e de outros que trataram de sair das atividades agrícolas. A cidade oferecia um campo aberto ao artesanato, ao comércio de rua, às fabriquetas de fundo de quintal, aos construtores denominados 'mestres italianos', aos profissionais liberais ${ }^{14}$.

O mesmo autor sustenta que a liberdade usufruída nos centros urbanos - em oposição à rigidez social do campo -, ao permitir a livre circulação de ideias, criou o terreno adequado para que surgissem movimentos sociais urbanos organizados pelos operários.

Não obstante as agitações da classe operária, como a Greve Geral de 1917, os trabalhadores permaneceram durante toda a década de 1920 com pouquíssima proteção legal, situação que permitiu, de acordo com o autor supracitado, a "ação do Estado através da política trabalhista de Getúlio Vargas"15, como se verá mais adiante.

O período que vai do início da República Velha à Revolução de 1930 é ainda marcado pelo liberalismo: embora a Constituição de 1891 assegurasse a liberdade de trabalho e o direito de associação, não mencionou expressamente o direito de sindicalização e deixou de lado aspectos específicos do trabalho que poderiam ser objeto de regulação.

Em relação ao Direito Processual, Octacílio Paula Silva ${ }^{16}$ considera que, até 1930, viveu-se uma fase de tentativas de implementação da jurisdição trabalhista. Entre tais tentativas, destacam-se as seguintes:

i) Lei $\mathrm{n}^{\mathrm{o}} 1.637$ de 5 de novembro de $1907^{17}$ : criou sindicatos profissionais e cooperativos e, em seu artigo $8^{\circ}$ previa a estruturação de Conselhos Permanentes de Conciliação e Arbitragem. Tratava-se de órgãos de composição paritária, destinados a dirimir as divergências e contestações entre capital e trabalho;

ii) Criação do Patronato Agrícola, órgão consultivo, destinado a resolver as dúvidas de empregadores e empregados rurais; e

\footnotetext{
${ }^{14}$ FAUSTO, Boris. História do Brasil. São Paulo: Edusp, 1997. p. 290.

15 Ibidem, p. 305.

${ }^{16}$ Ver SILVA, Octacílio Paula. Evolução histórica do direito processual do trabalho. In: BARROS, Alice Monteiro (Coord.). Compêndio de Direito Processual do Trabalho. São Paulo: LTr , 1998. p. 33.

${ }^{17}$ BRASIL. Lei no 11.637 de 5 de novembro de 1907. Cria sindicatos profissionais e cooperativas. Coleção das Leis de 1907. Atos do Poder Legislativo. Rio de Janeiro: Imprensa Nacional, 1941. p. 38 e 39. Disponível em: <http://www.camara.gov.br/Internet/InfDoc/novoconteudo/Legislacao/Republica/leisocerizadas/Leis 1907vIleg.pdf>. Acesso em: 20 jan. 2010.
} 
iii) Lei $\mathrm{n}^{\mathrm{o}} 1.869$, de 10 de outubro de 1922: criou os Tribunais Rurais de São Paulo que, destinados à resolução dos conflitos decorrentes da interpretação dos contratos de trabalho, tinham por características a ausência de custas, a adoção de uma forma processual simples e direta, um valor máximo de alçada e a composição paritária, sendo cada tribunal composto por um representante dos fazendeiros e um dos colonos.

Porém, como já afirmado, tratou-se de meras tentativas de implementação de uma jurisdição trabalhista: a mentalidade predominantemente liberal da época impedia que se concebesse um modelo de Judiciário Trabalhista tal qual veio a seguir, marcado pelo intervencionismo estatal.

O período que se seguiu à ascensão de Getúlio Vargas ao poder, em 3 de novembro de 1930, é caracterizado por uma mudança na postura do Estado perante a política econômica, em geral, e às relações de trabalho, especificamente. Tal mudança deuse em direção a uma ideologia corporativista, que pregava a necessidade de intervenção estatal em todos os campos da vida social, de modo a garantir a paz e o desenvolvimento econômico e social do país. Contrapunha-se ao liberalismo justamente no tocante à regulação do mercado e das relações de trabalho pelo Estado, embora continuasse a ser, essencialmente, capitalista. Também foi um contraponto ao comunismo - que ganhava força no cenário internacional -, por rejeitar a organização classista da sociedade, procurando garantir alguns direitos sociais. O corporativismo rejeitava também toda ação que visasse ao atendimento de interesses individuais: a ação deveria ser direcionada ao bem comum, ao fortalecimento do Estado. Os indivíduos eram concebidos como parcelas orgânicas do Estado, em uma relação vertical.

Durante o Governo Provisório, em 1932, fase considerada por Octacílio Paula Silva como de implantação da jurisdição trabalhista ${ }^{18}$, foram criados os primeiros órgãos de resolução de conflitos trabalhistas, de natureza administrativa, ligados ao Ministério do Trabalho, Indústria e Comércio:

i) Decreto $\mathrm{n}^{\mathrm{o}} 21.396$ de 12 de maio de $1932^{19}$ : instituiu as Comissões Mistas de Conciliação que, destinadas à composição dos conflitos coletivos de trabalho,

\footnotetext{
${ }^{18}$ SILVA, Octacílio Paula. Evolução histórica do direito processual do trabalho, p. 36.

${ }^{19}$ BRASIL. Decreto $\mathrm{n}^{\circ} 21.396$ de 12 de maio de 1932. Institui comissões mistas de conciliação e dá outras providências. Coleção das Leis da República dos Estados Unidos do Brasil de 1932. Atos do Governo Provisório. Rio de Janeiro: Imprensa Nacional, 1943. p. 235 e ss. Disponível em: <http://www.camara.gov.br/internet/InfDoc/novoconteudo/legislacao/republica/Leis1932vII624p/pdf29.pdf>. Acesso em: 17 dez. 2010.
} 
tinham natureza conciliatória e arbitral, sendo que as decisões jurisdicionais ficavam a cargo do Ministro do Trabalho;

ii) Decreto $\mathrm{n}^{\mathrm{o}} 22.132$ de 25 de novembro de 1932: instituiu as Juntas de Conciliação e Arbitragem, com a função de resolução dos conflitos individuais de trabalho entre empregadores e empregados sindicalizados. Embora as decisões fossem proferidas pelos vogais - representantes das classes patronal e laboral - e fossem irrecorríveis, o Ministro do Trabalho tinha o poder de avocar para si os processos, em casos de parcialidade dos julgados ou de violação de direito, o que, incluía até a possibilidade de anulação da decisão da Junta.

Em $1^{\circ}$ de maio 1943 foi promulgado o Decreto-Lei $\mathrm{n}^{\circ} 5.452$, aprovando a Consolidação das Leis do Trabalho. Tal consolidação traz as regras de organização da Justiça do Trabalho, tratando das juntas e tribunais em todos os níveis, e as normas processuais do Processo Trabalhista em geral. A partir de então, inicia-se a fase de consolidação da jurisdição trabalhista, sendo que apenas com a promulgação da Constituição de 1946 é que a Justiça do Trabalho foi integrada ao Poder Judiciário; em seu artigo 22, estavam previstos os órgãos que a comporiam: Tribunal Superior do Trabalho, Tribunais Regionais do Trabalho e Juntas e Juízes de Conciliação e Julgamento.

A criação da Justiça do Trabalho foi cercada por uma concepção conciliatória, evitando-se que os conflitos das relações de trabalho fossem resolvidos diretamente entre as partes e concedendo-se ao Estado, por meio do juiz, a competência para dirimir as tensões. É certo que, do ponto de vista dos direitos individuais, a criação da Justiça do Trabalho realmente significou um avanço na proteção do trabalhador, que passou a contar com um local oficial e adequado de proteção de seus direitos. Porém, segundo a perspectiva das relações coletivas, à Justiça do Trabalho foi concedido um papel além do meramente protetor, dispondo tal órgão do chamado "poder normativo", utilizado na resolução de dissídios coletivos entre sindicatos obreiros e sindicatos patronais ou empresas. Ora, essa função do Judiciário suprime a vontade privada dos acordos e convenções coletivos, impedindo que se forme "uma classe trabalhadora mais energética no enfrentamento das pressões e das imposições patronais" 20 .

John D. French, ao demonstrar que a CLT existia em meio a uma tensão entre realidade e ideal, aponta os dois posicionamentos principais dos militantes da classe

\footnotetext{
${ }^{20}$ BRASIL. Decreto $\mathrm{n}^{\circ} 21.396$ de 12 de maio de 1932. Institui comissões mistas de conciliação e dá outras providências, p. 232.
} 
trabalhadora em relação à legislação trabalhista: por alguns, era vista como um ideal a ser atingido e uma esperança; por outros, era apresentada como uma fraude. Contudo, tal autor aponta que o que prevaleceu na cultura popular foi justamente a primeira posição. As militâncias operárias utilizavam-se, inclusive, de um discurso legalista para fazer valer os direitos previstos na CLT. De qualquer maneira, não era raro encontrarem obstáculos extrajurídicos à suas pretensões, como foram repetidas decisões de cunho político proferidas pelo Tribunal Superior do Trabalho. O referido autor, então, ressalta que não se pode concluir que estes posicionamentos eram excludentes, nem que os que tratavam a CLT como uma conquista dos trabalhadores não partilhassem da visão crítica do outro segmento. Tratava-se, ainda de acordo com John D. French, de um cálculo pragmático dos fracos:

para qualquer grupo social, é sempre melhor se você pode ter a lei e o poder ao seu lado. Se você só puder ter um dos dois, o poder é evidentemente preferível à lei. Se você não tem o poder, entretanto, não se discute que lei ainda é inquestionavelmente melhor do que nada ${ }^{21}$.

A partir de então e até o fím do regime militar, não se observaram mudanças relevantes no tocante ao Direito Processual do Trabalho.

A Constituição Federal de 1988 talvez seja o único documento legal comparável à CLT no que diz respeito à extensão dos direitos trabalhistas e sociais. De fato, não apenas no aspecto trabalhista, a Constituição de 1988 é um documento extenso e minucioso, não fugindo à regra quando se trata dos direitos dos trabalhadores. A eles é dedicado todo um capítulo, que prevê desde o direito de greve até a licença-paternidade. Contudo, do mesmo modo que a CLT, o texto constitucional é eivado de contradições e ambiguidades: prevê a liberdade e autonomia sindicais, mas mantém a unicidade e o imposto sindicais; garante o direito de greve ao setor público, mas o condiciona a uma lei até hoje não redigida. Walküre Lopes Ribeiro Silva ${ }^{22}$ afirma que, a partir da promulgação da Constituição de 1988, iniciou-se um período "marcado pela permanência de uma herança corporativista e de tentativas de reforma, com debates sobre a flexibilização".

Em relação ao Direito Processual do Trabalho e à organização da Justiça do Trabalho, foram feitas mudanças substanciais, das quais se destacam:

i) a Emenda Constitucional $n^{\circ} 24$ de 9 de dezembro de 1999: extinguiu as Juntas de Conciliação e Julgamento, acabando com a representação classista na Justiça do

\footnotetext{
${ }^{21}$ FRENCH, John D. Afogados em leis: a CLT e a cultura política dos trabalhadores brasileiros. São Paulo: Fundação Perseu Abramo, 2001. p. 67.

${ }^{22}$ SILVA, Walküre Lopes Ribeiro. Direito do Trabalho Brasileiro, p. 133.
} 
Trabalho, que passou a ser composta apenas por juízes singulares, nomeados mediante aprovação em concurso público;

ii) a Lei $\mathrm{n}^{\circ} 9.957$ de 12 de janeiro de 2000: instituiu o procedimento sumaríssimo no Processo Trabalhista, de rito mais célere, limitado a um valor de alçada e com hipóteses de recurso limitadas;

iii) a Lei $n^{\circ}$ 9.958, de 12 de janeiro de 2000: criou as Comissões de Conciliação Prévia, órgãos extrajudiciais destinados à composição de conflitos trabalhistas. Há grande celeuma envolvendo a obrigatoriedade de submissão do litígio à Comissão de Conciliação Prévia antes da propositura da ação judicial, sendo que o Supremo Tribunal Federal, em 13 de maio de 2009, proferiu decisão liminar ${ }^{23}$ suspendendo $^{2}$ o disposto no artigo 625-D da CLT, que prevê tal obrigatoriedade; e

iv) a Emenda Constitucional $n^{\circ} 45$, de 30 de dezembro de 2004: entre suas principais alterações, ampliou a competência da Justiça do Trabalho para processar e julgar as ações oriundas da relação de trabalho, e não apenas das relações de emprego, e incluiu a necessidade do "comum acordo" para ajuizamento de dissídio coletivo.

Assim como ocorre com o Direito do Trabalho em boa parte do mundo, no Brasil também se verifica contraditoriedade entre os dispositivos legais que regulam as relações individuais e coletivas de trabalho, alternando entre uma legislação tradicionalmente corporativa e medidas de cunho liberal recorrentes, situação que gera extrema instabilidade e reflete-se inclusive na atuação do Judiciário, que não raro profere decisões completamente diferentes para casos similares.

Não obstante, a consideração dos direitos trabalhistas como direitos fundamentais - e direitos humanos, no plano internacional - repete a relação da classe trabalhadora com a CLT nos anos Vargas: tais direitos, por serem principiológicos, não são vistos como passíveis de aplicação direta, mas apenas como diretrizes norteadoras de conduta e de políticas sociais, obviamente condicionados à existência de condições econômicas adequadas. Tal é o princípio da reserva do possível, segundo o qual as normas sociais previstas na Constituição devem ser atendidas em um nível mínimo e a sua aplicação plena depende da conjetura financeira do Estado. Ora, neste sentido, a norma trabalhista permanece como um ideal, uma regra criada para não ser totalmente cumprida, cuja aplicação pode ser diferida de acordo com a vontade do capital.

\footnotetext{
${ }^{23}$ Ação Direta de Inconstitucionalidade no 2139 e Ação Direta de Inconstitucionalidade no 2160.
} 


\section{PROCESSO E RESOLUÇÃO DO CONFLITO}

\subsection{Conflito Social e Conflito Jurídico: o Papel do Pedido no Processo}

Ensinam Cândido Rangel Dinamarco, Ada Pelegrini Grinover e Antônio Carlos de Araújo Cintra $^{24}$ que toda atividade jurídica desempenhada pelo Estado visa à pacificação social, por meio da eliminação dos conflitos. $\mathrm{O}$ instrumento tradicionalmente utilizado pelo Estado para essa eliminação é o processo. Nesse sentido, pode-se afirmar que o principal objetivo do processo é dar efetividade ao Direito Material, eliminando os conflitos e recompondo a paz social. Assim, um ponto de partida adequado é a conceituação de conflito e a determinação de qual conflito é composto pela ação estatal.

Conflito é um conceito primordialmente sociológico. Ralf Darehndorf ${ }^{25}$ identifica duas teorias, não excludentes, que versam sobre o papel do conflito na sociedade. A primeira é denominada teoria da integração e seu representante mais conhecido é Talcott Parsons $^{26}$, cuja premissa é a de que a sociedade é um sistema perfeito em equilíbrio, mantido mediante a institucionalização de determinados processos. Sob essa perspectiva, o conflito é patológico. A segunda é a teoria da dominação (Herrschaftstheorie), de acordo com a qual a sociedade é uma forma de associação marcada pela dominação, cuja unidade é mantida pela força. Neste tipo de estrutural social, o conflito é próprio da sociedade, produzindo uma série de forças que levam ou à manutenção de um modelo ou à sua superação. De qualquer modo, a instabilidade e a tendência à mutação são as características da sociedade sob a ótica da teoria da dominação. Tal discussão também permeia o âmbito da Sociologia do Direito: embora estejam presentes as ideias de que o Direito tanto incorpora valores sociais (variável dependente) quanto é um promotor de

\footnotetext{
${ }^{24}$ DINAMARCO, Cândido Rangel; CINTRA, Antônio Carlos de Araújo; GRINOVER, Ada Pelegrini. Teoria Geral do Processo. São Paulo: Malheiros, 2003.

${ }^{25}$ DAREHNDORF, Ralf. Las clases sociales y su conflicto en la sociedad industrial. Madrid: Rialp, 1962. p. 207 e ss.

${ }^{26}$ Ver PARSONS, Talcott. Sociedades: perspectivas evolutivas e comparativas. São Paulo: Pioneira, 1969. Outros representantes dessa teoria são Comte, Spencer, Pareto e Durkheim.
} 
mudanças materiais e culturais (variável independente), persiste o debate acerca do seu papel conformador ou de dominação de $\operatorname{classe}^{27}$, embora a visão predominante na Academia ainda seja a do Direito como garantidor da composição harmoniosa dos conflitos.

Diante disto, fica evidente que conflitos não são originariamente jurídicos, mas traduzem-se juridicamente. Ora, já diz o ditado italiano: traduttore, traditore. É inegável que a "tradução" do conflito social para termos jurídicos importa em perdas. Em primeiro lugar, o Direito Processual exige que seja feito um "corte", devendo as partes trazer ao processo apenas uma parcela do conflito e o modo pelo qual ele deverá ser resolvido. Ademais, o conflito é levado ao juiz pela ótica das partes, narrado por elas, e sua solução está restrita à observância de adequação legal à solução proposta pelo autor e, eventualmente, pelo réu. A limitação da atividade jurisdicional aos termos do pedido formulado pela parte é a maior evidência desse corte, pois em conflitos de médio ou alto grau de complexidade, em tese, é possível mais do que uma solução; porém, não é dada ao juiz a possibilidade de compor o conflito dando uma solução diversa da pedida, ainda que haja, do ponto de vista social, solução mais adequada ${ }^{28}$.

Essa dissociação entre resolução "legal” e resolução "sociológica" do conflito fica ainda mais evidente no estudo do Direito do Trabalho, uma vez que é no objeto de regulação dessa área do Direito - a relação de trabalho - que se situa, por excelência, a luta de classes. Ressalta-se, contudo, que o projeto de legislação social brasileiro, iniciado com Vargas, não tinha por escopo o fim do conflito decorrente das relações de trabalho, mas sim a sustentação de um projeto de dominação burguesa de novo tipo ${ }^{29}$. Neste sentido, o conflito social permanece subjacente mesmo nas relações de trabalho que atendam totalmente a legislação aplicável.

Assim, não é exato afirmar, pura e simplesmente, que o fim do processo é a resolução do conflito - pelo menos não o é em relação ao conflito em sentido sociológico.

\footnotetext{
27 SANTOS, Boaventura de Souza. Introdução à sociologia da administração da justiça. In: FARIA, José Eduardo (Org.). Direito e Justiça. São Paulo: Ática, 1989. p. 40.

${ }^{28} \mathrm{Na}$ síntese de José Roberto Freire Pimenta, "não se pode esquecer nunca que o processo e a própria função jurisdicional do Estado têm limites que decorrem da própria natureza das coisas, inerentes aos instrumentos jurídicos em geral e ao próprio Direito. É, portanto, ingênuo e ilusório atribuir à função jurisdicional do Estado a tarefa de fornecer sempre uma solução absoluta, pronta e acabada para todo e qualquer conflito intersubjetivo de interesses, tão logo este se verifique - isto é humanamente impossível". Ver PIMENTA, José Roberto Freire. A conciliação judicial na justiça do trabalho após a emenda constitucional n. 24/99: aspectos de direito comparado e o novo papel do juiz do trabalho. LTr : legislação do trabalho, São Paulo, v. 65, n. 2, fev. 2001, p. 153.

${ }^{29}$ ANTUNES, Ricardo. Construção e desconstrução da legislação social no Brasil. In: (Org.).

Riqueza e miséria do trabalho no Brasil. São Paulo: Boitempo, 2006.
} 
O Código de Processo Civil refere-se, com frequência, à resolução da lide como o fim do processo. Assim, uma breve investigação sobre o tratamento dispensado à lide na doutrina tradicional mostrará como esse conceito relaciona-se com o de conflito.

Enrico Tulio Liebman reconhece o mérito da doutrina carneluttiana ao conceituar lide como conflito de interesses qualificado pela pretensão de um dos interessados e pela resistência do outro. De acordo com este autor, Francesco Carnelutti fez uma ousada tentativa de identificar o elemento material do processo. Tal elemento, então, seria o conflito de interesses, anterior e exterior ao processo, o qual, conjugado com os elementos formais do processo (pretensão e resistência), formaria a lide. Contudo, para Enrico Tulio Liebman, que segue Piero Calamandrei, esse conceito é sociológico e não jurídico. Como foi visto acima, o conflito não é levado para o processo em sua naturalidade. O artigo 282 do CPC determina que a petição inicial deve indicar, entre outras coisas, os fatos e fundamentos jurídicos do pedido e o pedido, com suas especificações. Assim, não é permitido ao autor instituir o processo apenas levando ao conhecimento do juiz a existência de um conflito e requerendo simplesmente que a questão seja resolvida da maneira justa. O conflito de interesses no processo deve ser construído juridicamente pelo autor, a quem a lei dá "a liberdade, a iniciativa e a responsabilidade da escolha no modo de resolver a controvérsia" ${ }^{\text {30 }}$, cabendo ao juiz unicamente decidir se a solução proposta está de acordo com o Direito ou não. Assim, para Enrico Tulio Liebman, lide é o conflito virtual ou efetivo de pedidos contraditórios.

Ora, diante dessa conceituação, fica evidente o papel do pedido no processo. Se ao juiz é permitido apenas decidir se possui fundamento jurídico a solução proposta para o conflito, isso significa dizer que ao juiz é lícito apenas se manifestar sobre a procedência ou não do pedido, levando à conclusão, portanto, que o objeto do processo é o pedido do autor.

No Processo do Trabalho, não há tratamento diferenciado para o conceito de pedido. Sendo a CLT omissa quanto às características e ao conteúdo do pedido, a doutrina processual trabalhista adota a aplicação subsidiária das disposições do CPC no tocante a este tema ${ }^{31}$.

\footnotetext{
${ }^{30}$ LIEBMAN, Enrico Tulio. O despacho saneador e o julgamento do mérito. Revista dos Tribunais, São Paulo, v. 88, n. 767, p. 737-753, set. 1999.

${ }^{31}$ Ver NASCIMENTO, Amauri Mascaro. Curso de direito processual do trabalho. São Paulo: Saraiva, 1997. p. 370; BEZERRA LEITE, Carlos Henrique. Curso de direito processual do trabalho. São Paulo: LTr , 2007. p. 431.
} 
Pode-se distinguir o pedido imediato do pedido mediato. O primeiro relaciona-se ao tipo de provimento requerido (declaração, constituição ou condenação), enquanto o segundo diz respeito ao bem da vida pleiteado. A doutrina nacional processual-civilista defende que o princípio da congruência vincula a sentença tanto ao pedido mediato quanto ao pedido imediato ${ }^{32}$.

Além disso, determina o CPC que o pedido deve ser certo e determinado. A determinação do pedido visa caracterizar exatamente o bem da vida que se pretende, enquanto a certeza do pedido explicita a quantidade e a extensão desse bem. Tais características ligam-se diretamente à ideia de que não é permitido ao juiz resolver o conflito do modo que achar justo; também não é permitido ao autor, sob pena de indeferimento da inicial, formular pedido vago, como é "o pedido de condenação do réu às custas da lei, ou ao que for devido, ou a pagar uma indenização, sem esclarecer desde logo quais penas são essas ou em que consiste o prejuízo sofrido",33. É verdade que são admitidas exceções ao artigo 286 do CPC, podendo o autor formular pedido indeterminado nas seguintes situações: (i) quando a demanda disser respeito a universalidades e não for possível, no momento da propositura da ação, individualizar os bens ou direitos que as compõem; (ii) quando a demanda basear-se em fatos ou atos que ainda não produziram todos os efeitos; e (iii) se a quantificação ou extensão do pedido depender de ato praticado pelo réu. Não obstante a regra da certeza e determinação do pedido, a prática ensina que o pedido formulado na petição inicial, como toda expressão linguística, está sujeito a mais de uma interpretação. Assim, de modo a garantir a precisão do pedido, o legislador determinou que a interpretação do pedido deve ser feita de modo restritivo.

Todas essas regras, não há dúvidas, destinam-se a garantir que o réu, recebendo a petição inicial, tenha a possibilidade de se defender adequadamente, garantindo-se, com isso o efetivo direito ao contraditório. Ou seja, garantem que o réu possa prever o pior resultado possível de uma sentença de procedência. Assim, é praticamente unânime a doutrina processual nacional ao afirmar que o pedido delimita a atividade judicial, determinando a circunferência dentro da qual o litígio é deduzido, discutido e julgado.

A questão da delimitação da lide será retomada no Capítulo 3, quando serão estudados com profundidade o princípio da congruência e o papel desempenhado pela causa de pedir e pelas respostas do réu na determinação do objeto do processo.

\footnotetext{
${ }^{32}$ CARMONA, Carlos Alberto. Em torno da petição inicial. Revista de Processo, São Paulo, v. 30, n. 119, jan. 2005. p. 11-34.

${ }_{33}$ DINAMARCO, Cândido Rangel. Instituições de Direito Processual Civil. v. 2. São Paulo: Malheiros, 2001. p. 158.
} 


\title{
2.2 Resolução do Conflito Jurídico: Escopos do Processo e Efetividade da Norma
}

O reconhecimento da limitação do Direito, em geral, e do processo, em especial, na resolução dos conflitos sociais não implica, por óbvio, sua desconsideração. Ao contrário, faz-se necessária a mais completa busca por sua efetividade, de modo a garantir a convivência harmoniosa possível na sociedade.

A efetividade, ou eficácia, é qualidade essencial das normas jurídicas, tendo papel de profunda relevância na manutenção da integridade e coesão do ordenamento jurídico. Sob uma perspectiva essencialmente positivista ${ }^{34}$, a ineficácia prolongada de uma norma pode ocasionar a perda de sua validade ${ }^{35}$. Tal relação, levada a uma situação extrema, pode resultar no que Ferdinand Lassale identificou como um divórcio entre a Constituição real e a Constituição escrita: "Y se esto sucede [a Constituição real apresentar algo que não se ajusta à Constituição escrita], si este divorcio existe, la Constitución escrita está perdida, y no hay Diós ni hay grito capaz de salvarla"36.

Não se pode olvidar, também, que a distância entre o dever ser e o ser tem diversas consequências na percepção que a sociedade - e não apenas os operadores do Direito - tem da lei. No campo das relações de trabalho, essa dissociação entre a lei e a realidade é especialmente marcante e, como vimos, teve profundas consequências na formação da classe trabalhadora brasileira e da Justiça do Trabalho.

A efetividade da norma, contudo, não pode ser confundida com a sua obediência, sendo esta apenas uma dos critérios possíveis de mensuração da efetividade da norma. Conforme ensina Tercio Sampaio Ferraz Junior, a

\begin{abstract}
eficácia social ou efetividade de uma norma não se confunde, porém, com a sua observância. A obediência é um critério importante para o reconhecimento da efetividade, mas esta não se reduz à obediência. (...) Não se reduzindo à obediência, a efetividade ou eficácia social tem antes o sentido de sucesso normativo, o qual pode ou não exigir obediência. Se o sucesso normativo exige obediência, devemos distinguir, presentes os requisitos fáticos, entre a observância espontânea e observância por imposição de terceiros (por exemplo, sua efetiva aplicação pelos tribunais). Uma norma é, então, socialmente ineficaz de modo pleno se não for observada nem de um modo nem de outro ${ }^{37}$.
\end{abstract}

\footnotetext{
${ }^{34}$ KELSEN, Hans. Teoria pura do direito. Coimbra: Armênio Amado, 1974. p. 298.

${ }^{35}$ Ressalta-se, porém, que Kelsen repudia a identificação de validade com eficácia, admitindo a existência de normas ineficazes que permanecem válidas e até mesmo normas eficazes inválidas. Para este autor, a eficácia é uma condição da validade, mas com ela não se confunde. Ibidem, p. 299.

${ }^{36}$ LASSALE, Ferdinand. Qué es la Constitución? Santa Fe de Bogotá: Temis, 1997. p. 76.

${ }^{37}$ FERRAZ JUNIOR, Tercio Sampaio. Introdução ao estudo do direito - técnica, decisão dominação. São Paulo: Atlas, 2001. p. 195 e 196.
} 
Nota-se, portanto, que o Estado, quer pelo Poder Judiciário, quer administrativamente, tem papel fundamental na manutenção da eficácia da norma. A existência de interesses distintos e, especialmente, opostos em uma dada sociedade implica sempre algum grau de inobservância das normas postas pelos seus membros. O Estado, ainda que apenas idealmente, deve se afastar desses interesses particulares e exercer uma função regulatória, com vistas à proteção e à manutenção do interesse público, em regra, consonante com a ordem jurídica. Tal papel intensifica-se se considerar que o Estado brasileiro, sob a égide da Constituição cidadã, é um verdadeiro Estado Social, cuja função principal é a promoção da realização plena dos valores humanos, em geral, e, no tocante ao processo, tal realização traduz-se na garantia de um processo que, de fato, proporcione não simplesmente o acesso à justiça, mas também a sua realização. Nesse sentido, a figura criada por Edmar Souza Salgado é esclarecedora: o Estado é o fiador da efetividade ${ }^{38}$.

Como bem nota José Roberto Freire Pimenta, a aplicação das normas de Direito Material pelos tribunais não deixa de ser um instrumento de incentivo ao cumprimento espontâneo da lei, criando uma situação de segurança jurídica desestimuladora do descumprimento legal, uma vez que o destinatário da norma não vislumbrará alternativa ${ }^{39}$. É fato notório o impacto da jurisprudência no tocante à efetividade das normas, havendo, por vezes, uma verdadeira inversão na pirâmide normativa, partindo os operadores do Direito, para a resolução de um dado caso, das súmulas dos tribunais até chegar à Constituição Federal. Não obstante alguns excessos, não se pode negar o papel primordial do Judiciário, não apenas como restaurador de direitos, mas também como promotor da defesa da ordem jurídica vigente, garantindo a sua eficácia.

Contudo, a realização da função do Judiciário como responsável pela atuação da vontade concreta do Direito Material não depende apenas da afirmação do direito de ação e das garantias do devido processo legal previstas na Constituição Federal. Tais direitos, embora indispensáveis, relacionam-se ao direito de petição - direito abstrato e incondicionado de propor uma demanda, de obter um pronunciamento judicial sobre determinada situação levada a juízo. Este direito, contudo, não tem qualquer relação com o direito material discutido, não podendo ser estendido a um direito de obter pronunciamento judicial favorável. Como ensina José Roberto dos Santos Bedaque, "todos têm direito ao

\footnotetext{
${ }^{38}$ SALGADO, Edmar Souza. O princípio da efetividade no processo do trabalho. São Paulo, 2008. $264 \mathrm{f}$. Dissertação (Mestrado) - Faculdade de Direito da Universidade de São Paulo. Orientação do Professor Jorge Luiz Souto Maior. p. 18.

${ }^{39}$ PIMENTA, José Roberto Freire. A conciliação judicial na justiça do trabalho após a emenda constitucional n. 24/99, p. 156.
} 
método estatal de solução de controvérsias, tal como concebido pelo legislador constitucional (devido processo legal). Mas a tutela jurisdicional será concedida àquele cujo interesse estiver protegido no plano material" ${ }^{\prime 40}$. Eis onde reside, portanto, o verdadeiro significado atual de acesso à justiça: a garantia de um processo que não seja simplesmente célere e contraditório, mas que produza resultados social e individualmente justos $^{41}$.

A produção adequada de resultados implica a eliminação da crise jurídica que é objeto do processo. Quanto mais próxima essa eliminação estiver da eliminação do conflito em seu sentido sociológico, mais efetividade terá o processo em sua função de pacificação social. Portanto, a partir da premissa de que o processo deve ser efetivo, garantindo a integridade da ordem jurídica, José Roberto dos Santos Bedaque afirma a necessidade de "revisitar" os institutos processuais: "menos tecnicismo e mais justiça"42. Tal revisitação pode ser feita de duas maneiras: pela modificação legal dos institutos processuais ou pela alteração da mentalidade dos operadores do Direito. De um modo ou de outro, o que se tem observado é que a busca pela efetividade do processo demanda uma revisitação profunda, atingindo procedimentos clássicos do processo e, muitas vezes, subvertendo normas e princípios tidos como absolutos. Este é, evidentemente, o caso do princípio da congruência e a admissibilidade de julgamento ultra ou extra petita: em que medida a flexibilização do princípio da congruência pode ensejar a efetividade processual e quais os prejuízos que podem dela decorrer? Embora tal questão vá ser tratada com mais profundidade no Capítulo 3, há que se ter em mente que a análise dos institutos processuais e a sugestão de sua alteração devem, invariavelmente, levar em conta o Direito Material, criando-se procedimentos adequados para atender as peculiaridades de cada situação. Mais uma vez, José Roberto dos Santos Bedaque sustenta que "o direito processual deve adaptar-se às necessidades específicas de seu objeto, apresentando formas de tutela e de procedimento adequadas às situações de vantagem asseguradas pela norma substancial”,43. Tal concepção tem especial impacto no estudo do Direito Processual do Trabalho, como se verá adiante.

\footnotetext{
${ }^{40}$ BEDAQUE, José Roberto dos Santos. Direito e Processo - influência do direito material sobre o processo. São Paulo: Malheiros, 2009. p. 40.

${ }^{41}$ Tal posição é a de Kazuo Watanabe, ao falar de instrumentalismo substancial, em oposição ao instrumentalismo meramente formal. Ver WATANABE, Kazuo. Da Cognição no Processo Civil. São Paulo: Revista dos Tribunais, 1987. p. 16.

42 BEDAQUE, José Roberto dos Santos. Op. cit., p. 18 e 19.

${ }^{43}$ Ibidem, p. 23.
} 


\subsection{O Problema Atual da Efetividade dos Direitos Trabalhistas}

\subsubsection{Efetividade e Irrenunciabilidade da Norma Trabalhista}

Como visto no Capítulo 1, os direitos trabalhistas sempre confrontaram a questão da falta de efetividade, caracterizada por um distanciamento entre a norma prescrita e a realidade. Esse distanciamento, contudo, ganhou maior relevância a partir de 1988, com a inserção dos direitos trabalhistas no rol de direitos fundamentais, consagrando o entendimento já predominante acerca do caráter público, imperativo e inderrogável das normas trabalhistas, previsto no artigo $9^{\circ}$ da CLT. Trata-se do reconhecimento último de que o Direito do Trabalho é, dentro do sistema capitalista, "o mais generalizante e consistente instrumento assecuratório de efetiva cidadania, no plano socioeconômico, e de efetiva dignidade, no plano individual. Está-se diante, pois, de um potente e articulado sistema garantidor de significativo patamar de democracia social"44.

Tal caráter tem impacto direto na irrenunciabilidade dos direitos trabalhistas, devendo as partes, no momento da elaboração do contrato de trabalho, obedecer ao conteúdo mínimo prescrito em lei, sob pena de nulidade. É o que se depreende do disposto no artigo 468 da CLT. Essa norma encontra fundamento na desigualdade econômica entre empregado e empregador, evitando que intempéries econômicas levem à celebração de contratos contrários ao interesse social, submetendo os trabalhadores a condições degradantes de trabalho.

Américo Plá Rodriguez sustenta que a irrenunciabilidade é princípio próprio do Direito do Trabalho e identifica quatro fundamentos mais recorrentes para tal princípio, os quais, por vias diversas, chegam à mesma ideia ${ }^{45}$.

O primeiro é o princípio da indisponibilidade, que limita a disponibilidade dos direitos de natureza trabalhista por parte do empregado, como medida de proteção frente ao poder do empregador. Proíbe-se, portanto, a renúncia de direitos, mas não somente isto: esse princípio também se desdobra na intransigibilidade dos direitos trabalhistas, vedando, portanto, a diminuição da proteção legal do trabalhador, seja por mera renúncia, seja por transação.

O segundo, destacado também por Mario de La Cueva, é a imperatividade da norma trabalhista, em oposição ao caráter dispositivo da legislação civilista, cabendo ao

\footnotetext{
${ }^{44}$ DELGADO, Maurício Godinho. Capitalismo, trabalho e emprego. São Paulo: LTr, 2008. p. 142.

${ }^{45}$ PLÁ RODRIGUES, Américo. Princípios de Direito do Trabalho. São Paulo: LTr, 1978. p. 67 e ss.
} 
Estado estabelecer as normas que vão regular as relações de trabalho. Mario de La Cueva entende que tal caráter é essencial para que o Direito do Trabalho tenha um mínimo de garantias e que cumpra a sua função social, qual seja, a de reparar as desigualdades socioeconômicas decorrentes da exploração do trabalho pelo capital. Tal autor sustenta, ainda, que a imperatividade da norma trabalhista se exerce em três direções: (i) aos trabalhadores, para que não se esqueçam que a norma possui uma finalidade social e que o desrespeito ao contrato individual de trabalho implica o desrespeito aos direitos de toda a classe trabalhadora; (ii) ao empresariado, como uma obrigação constitucional, imposta pelo povo; e (iii) ao Estado, impondo-lhe a obrigação de constante fiscalização e intervenção para garantir o cumprimento do Direito do Trabalho ${ }^{46}$.

O terceiro ponto é o caráter de ordem pública da norma trabalhista, o que impede, numa relação direta, a renúncia do direito. A identificação de tal caráter em determinada lei revela que o que é objeto de sua regulamentação é considerado essencial para a manutenção dos princípios e valores que regem determinada sociedade e a sua violação pode levar, em última instância, à anulação de uma política social. Ora, no caso do Direito do Trabalho, é certo que a transgressão da legislação trabalhista importa na negação do Estado Social, dos preceitos constitucionais que preveem que a República Federativa do Brasil é baseada na cidadania, na dignidade da pessoa humana e no valor social do trabalho. Logo, a irrenunciabilidade da norma de ordem pública é condição necessária para a manutenção dos alicerces fundamentais de um Estado e sua sociedade.

Por fim, Américo Plá Rodriguez registra que alguns autores afirmam ser a irrenunciabilidade da norma trabalhista uma consequência da limitação da autonomia imposta pelo Direito do Trabalho. Contudo, tal autor ressalta que

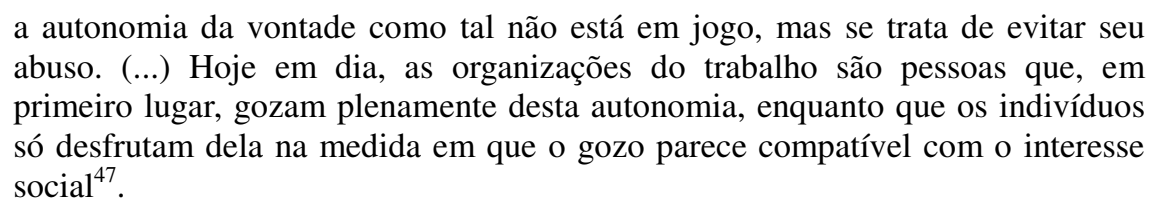

Tem-se, portanto, que, por qualquer via que seja, a legislação trabalhista tem a sua irrenunciabilidade fundada na posição débil do empregado frente ao empregador e na profunda rejeição ao passado sombrio das relações de trabalho, buscando-se garantir uma sociedade baseada no trabalho e que seja livre e democrática. A irrenunciabilidade é, neste sentido, característica ontológica do Direito do Trabalho.

\footnotetext{
${ }^{46}$ CUEVA, Mario de la. El nuevo derecho mexicano del trabalho. México: Porruá, 1977. p. 99 e ss.

${ }^{47}$ PLÁ RODRIGUES, Américo. Princípios de Direito do Trabalho, p. 76.
} 
Não obstante seu caráter irrenunciável, a legislação trabalhista no Brasil, mesmo após o advento da Constituição de 1988, continua padecendo de uma ineficácia crônica. Maurício Godinho Delgado aponta que, enquanto na Europa, cerca de $80 \%$ da população tem seu trabalho regido pela legislação trabalhista, no Brasil, apenas $30 \%$ da população está integrada na sociedade econômica pela via civilizatória do Direito do Trabalho ${ }^{48}$. Diante disto, a efetividade da norma trabalhista transcende a problemática da segurança jurídica pela constância das normas no sistema, sendo conditio sine qua non para a garantia de condições de trabalho dignas, solução encontrada pelo sistema capitalista para conter as agitações sociais decorrentes das relações de trabalho.

\subsubsection{O Papel do Estado no Cumprimento das Normas Trabalhistas}

Além da questão da efetividade, a norma trabalhista conta com mais uma peculiaridade, que é a polêmica em torno do cabimento da intervenção estatal no domínio das relações de trabalho. Conquanto tal questão tenha passado por momentos de menor relevância, em especial nos períodos de predomínio da ideologia corporativista, hoje, em face da retomada da hegemonia cultural do liberalismo extremado ${ }^{49}$, proposições de incremento do poder judicial não podem ser desacompanhadas de uma justificativa sólida.

Ademais, a manutenção de condições dignas de trabalho e o combate à exclusão social não se relacionam obrigatoriamente com a defesa de um Estado inexoravelmente intervencionista e a rejeição sumária de todos os princípios do liberalismo. Ao contrário, como foi visto no Capítulo 1, a luta da classe trabalhadora no início do século XX foi marcada pelo ideário anarquista, que partilha com o liberalismo, guardadas as devidas proporções, os seguintes aspectos: a valorização da autonomia, a rejeição ao Estado e a preferência do contrato sobre a lei ${ }^{50}$. Por outro lado, Walküre Lopes Ribeiro Silva sustenta que nem sempre o intervencionismo estatal é bom para a sociedade, afirmando que

\footnotetext{
o corporativismo caracteriza-se como um intervencionismo maléfico para a sociedade, na medida em que cerceia a liberdade sindical e submete os sindicatos ao Estado, que desempenha o papel de único dirigente da política socioeconômica e árbitro supremo dos conflitos sociais ${ }^{51}$.
}

\footnotetext{
${ }^{48}$ DELGADO, Maurício Godinho. Capitalismo, trabalho e emprego, p. 142.

${ }^{49}$ Ibidem, p. 80.

${ }^{50}$ D'AURIA, Aníbal et al. El anarquismo frente al derecho. Buenos Aires: Utopia Libertaria, 2007. p. 11 e ss.

${ }^{51}$ SILVA, Walküre Lopes Ribeiro. Autonomia privada coletiva. In: SOUTO MAIOR, Jorge Luiz; CORREIA, Marcus Orione Gonçalves. Curso de Direito do Trabalho - Direito Coletivo do Trabalho. São Paulo: LTr, 2008. p. 58 .
} 
Pois bem, no tocante à defesa dos direitos trabalhistas, o sindicato surge como o principal agente de luta e de transformação, tendo como instrumentos de atuação a greve e a negociação coletiva. Paulo Eduardo Oliveira sustenta que as vantagens da negociação coletiva desdobram-se em dois aspectos: juridicamente, regulamenta as relações de trabalho por meio de normas "diretamente conformadas pelo jogo de forças que integram aquela dinâmica social e (...) ajustadas ao particularismo das atividades profissionais e econômicas e das zonas geográficas"; no plano sociopolítico, tem inequívoco papel de concertação social, "condicionando os ambientes e trabalho, a estrutura do emprego, a repartição funcional dos rendimentos, a satisfação de necessidades coletivas, a estabilidade social e até, em certa medida, o funcionamento das instituições políticas" ${ }^{\Perp 52}$. Ademais, a convenção coletiva, fruto da negociação coletiva, é considerada expressão do pluralismo jurídico, fator de democratização das relações sociais, uma vez que representa o reconhecimento da existência de outras fontes formais do Direito, além da estatal.

Levando-se em consideração, portanto, a ponderação de interesses envolvida na negociação coletiva, é possível afirmar que as normas daí decorrentes têm, potencialmente, mais chances de serem espontaneamente cumpridas do que as normas estatais. Ademais, a utilização da greve como meio de pressão também é instrumento indispensável para a garantia da efetividade do Direito do Trabalho, sem que se tenha que recorrer ao Judiciário.

Ocorre, porém, que tais vantagens apenas podem ser observadas se garantida a liberdade sindical, em todas as suas cinco dimensões: (i) liberdade de associação; (ii) liberdade de organização; (iii) liberdade de administração; (iv) liberdade de exercício das funções; e (v) liberdade de filiação e desfiliação ${ }^{53}$. No Brasil, como já visto no Capítulo 1 , o movimento sindical foi marcado por forte intervenção estatal, que jamais permitiu o seu pleno exercício. Mesmo após a Constituição de 1988, “não houve um rompimento total com a concepção corporativista, uma vez que restaram alguns de seus traços, como por exemplo, o princípio da unicidade sindical, o poder normativo da Justiça do Trabalho e o imposto sindical" ${ }^{54}$. Acrescente-se a este quadro, ainda, a crise mundial de representatividade dos sindicatos, em seu modelo clássico, e o Estado - em especial o Poder Judiciário - surgirá, necessariamente, como a última instância para a garantia da efetividade das normas trabalhistas. Nas palavras de Ana Farias Hirano, "diante da

\footnotetext{
52 OLIVEIRA, Paulo Eduardo. Negociação coletiva. In: SOUTO MAIOR, Jorge Luiz; CORREIA, Marcus Orione Gonçalves. Curso de Direito do Trabalho - Direito Coletivo do Trabalho. São Paulo: LTr, 2008. p. 127.

${ }^{53}$ NASCIMENTO, Amauri Mascaro. Direito Sindical. São Paulo: Saraiva, 1991. p. 115.

${ }^{54}$ SILVA, Otávio Pinto e. A questão da liberdade sindical. In: SOUTO MAIOR, Jorge Luiz; CORREIA, Marcus Orione Gonçalves. Op. cit., p. 76.
} 
debilidade dos sindicatos, do movimento coletivo dos trabalhadores, e da fiscalização insuficiente do Estado, resta ao empregado que teve seus direitos negados pelo empregador, recorrer ao Judiciário" ${ }^{, 55}$.

Assim, o incremento dos poderes do juiz - um aspecto do intervencionismo estatal - deve ser visto como uma medida de garantia e potencialização da efetividade dos direitos trabalhistas diante da atual crise de representatividade dos sindicatos. Nota-se, contudo, que, pela natureza corretiva das decisões judiciais - em oposição ao caráter preventivo dos atos do Poder Executivo -, tal incremento não pode surgir isolado, devendo sempre estar acompanhado de uma proposta de política pública que vise até mesmo evitar a provocação do Judiciário, incentivando o cumprimento espontâneo da lei. Diante disto, o intervencionismo estatal legitima-se não por uma ideologia corporativista de que empregados e empregadores integram-se ao Estado numa relação vertical, mas sim por uma ação bifronte, criando mecanismos para a resolução efetiva dos conflitos levados a juízo e, ao mesmo tempo, abrindo espaço para a participação da sociedade civil, organizada em grupos sociais, na tomada de decisões sobre os rumos das políticas sociais e econômicas do país. Decerto, tal modelo - de inspiração inegavelmente democrática ainda é incipiente no Brasil e, não obstante os avanços na legislação sindical, como o reconhecimento jurídico das Centrais Sindicais, ainda há um longo caminho até que os movimentos sociais atinjam sua plena capacidade, o que depende, em grande medida, de um forte posicionamento do Estado para coibir a criminalização de movimentos constitucionalmente legais e legítimos e de uma reformulação dos modelos clássicos de organização de trabalhadores em face das mudanças estruturais que vêm ocorrendo no mundo do trabalho ${ }^{56}$.

\subsection{Peculiaridades do Processo e da Justiça do Trabalho}

Como se viu, a estruturação da Justiça do Trabalho e a elaboração de seu processo foram e continuam sendo determinados por uma série de fatores, desde a essência do

\footnotetext{
55 HIRANO, Ana Farias. Acordos Homologados pela Justiça do Trabalho: Transação de Direitos Controvertidos ou Renúncia a Direitos Indisponíveis? São Paulo, 2009. 280 f. Dissertação (Mestrado) Faculdade de Direito da Universidade de São Paulo. Orientação do Professor Jorge Luiz Souto Maior. p. 19. Disponível em: <http://www.teses.usp.br/teses/disponiveis/2/2138/tde-13082009-092724/>. Acesso em: 21 dez. 2010.

${ }^{56}$ Sobre os novos movimentos sociais, surgidos a partir da década de 1970, ver ELEY, Geoff. Forjando a democracia. São Paulo: Perseu Abramo, 2002. Capítulo 26.
} 
Direito Material do Trabalho até a atual crise de representatividade dos sindicatos. Todos esses elementos, porquanto componentes do modo de resolução do conflito trabalhista, devem ser considerados no presente estudo.

Pois bem. No Capítulo 1 foi dado destaque ao surgimento e desenvolvimento do Processo do Trabalho, processo que se deu paralelamente ao do Processo Comum: de fato, a Justiça do Trabalho nasce como órgão administrativo, voltado mais para a conciliação do que para a imposição do cumprimento das normas de natureza trabalhista. Mesmo após a sua incorporação ao Judiciário, em 1946, a Justiça do Trabalho manteve-se como órgão especializado e o seu processo continuou regulado por lei especial, a CLT. Aliás, apesar de pouco ressaltado, deve ser considerado de extrema relevância hermenêutica o fato de que o Processo Trabalhista está regulado na mesma norma que prevê o Direito Material do Trabalho. Em vez de ser mera coincidência formal, trata-se de uma evidência de que o Direito Processual está necessariamente ligado ao Direito Material, nele encontrando fundamento para seus mecanismos.

Dessa ligação, contudo, não se infere que o Direito Processual do Trabalho constitui matéria autônoma do Direito Processual Comum, muito menos da Teoria Geral do Processo. É inegável que existem institutos fundamentais ao processo, presentes tanto no Direito Processual do Trabalho quanto no Direito Processual Comum, em especial os previstos na Constituição Federal, como o direito ao contraditório e a proibição de tribunais de exceção, princípios que devem ser considerados na gênese da norma processual, seja qual for sua natureza. Ressalta-se, contudo, que não se trata de uma relação vertical, pela qual o Processo do Trabalho "aprende" com o Processo Comum: as últimas reformas do Processo Civil incorporaram diversos princípios e institutos tipicamente trabalhistas, como a oralidade, a imediatidade, a concentração dos atos, a rapidez, o impulso de ofício e a gratuidade ${ }^{57}$. Ao contrário do que sustenta Américo Plá Rodriguez, tal incorporação não retira a importância desses princípios para a resolução dos conflitos trabalhistas, apenas denota o reconhecimento de outros conflitos semelhantes no âmbito civil. Assim, nos dizeres de Manoel Carlos Toledo Filho, apesar da inexistência de uma diferença fundamental entre o Processo Comum e o Trabalhista, "a jurisdição [trabalhista] especializada fornece um ambiente propício à aceitação dos valores que ela mesma necessita para sua adequada concretização" ${ }^{\text {"58 }}$.

\footnotetext{
${ }^{57}$ Américo Plá Rodriguez sustenta que estes seis princípios e institutos trabalhistas foram assimilados, com mais ou menos sucesso, pelo Processo Comum. Ver PLÁ RODRIGUEZ, Américo. Visión crítica del derecho del trabajo. In: GIGLIO, Wagner D. (Coord.). Processo do Trabalho na América Latina. São Paulo: LTr , 1992. 58 TOLEDO FILHO, Manoel Carlos. Fundamentos e perspectivas do processo trabalhista brasileiro. São Paulo, 2005. XX f. Tese (Doutorado) - Faculdade de Direito da Universidade de São Paulo. Orientação do
} 
A partir do trabalho de Américo Plá Rodriguez ${ }^{59}$, serão abordadas as peculiaridades que, no entender desse autor, permaneceram muito mais profundas no Processo Trabalhista: (i) a desigualdade compensatória; (ii) a busca da verdade real; e (iii) a indisponibilidade. Mais importante do que comprovar que tais princípios estão mais presentes no Processo do Trabalho do que no Comum é demonstrar a relevância crucial que desempenham na aplicação da norma processual trabalhista.

\subsubsection{Desigualdade Compensatória}

Chamado por Américo Plá Rodriguez de princípio da desigualdade compensatória, o princípio protetor é reconhecido como específico do Direito Processual do Trabalho por diversos autores latino-americanos, que sustentam que a persistência da desigualdade substancial entre empregados e empregadores, presente no contrato de trabalho, justifica o tratamento desigual também no plano do Direito Processual.

Alberto Trueba Urbina afirma que, no Direito do Trabalho, tanto as normas substantivas como as processuais são essencialmente protecionistas e tutelares dos trabalhadores $^{60}$. Eduardo Couture, de sua parte, entende que tal proteção é necessária para evitar que o litigante empregador, mais capacitado economicamente para enfrentar a lide, possa utilizar-se de artifícios para desvirtuar e desviar os fins da Justiça ${ }^{61}$.

Há que se notar, contudo, que o afã de defender os direitos dos trabalhadores não pode desviar o aplicador do Direito de questões técnicas: como bem apontado por Nestor de Buen ${ }^{62}$, embora tanto o Direito Material quando o Direito Processual do Trabalho destinem-se à proteção do trabalhador, a aplicação do princípio protetor difere nos dois planos. Enquanto no plano material tal princípio evidencia-se pela criação de normas impositivas, inclusive desconsiderando a vontade das partes, no plano processual ele se revela pelo reconhecimento de que o trabalhador deve ser auxiliado pela parte julgadora.

A adoção da teoria instrumental do processo, como já defendido antes, permite logicamente a conclusão de que o caráter tutelar do Direito Material do Trabalho se transmite ao Direito Processual do Trabalho. Assim entende Wagner D. Giglio, que,

Professor Marcus Orione Gonçalves Correia. p. 52.

${ }_{59}^{5}$ PLÁ RODRIGUEZ, Américo. Princípios de Direito do Trabalho, p. 23.

${ }^{60}$ TRUEBA URBINA, Alberto. Nuevo derecho procesal del trabajo. México: Porruá, 1973. p. 40 e 73.

${ }^{61}$ COUTURE, Eduardo. Algunas nociones fundamentales del derecho procesal del trabajo. Santa Fé: Instituto de Derecho del Trabajo; Facultad de Ciencia Juridicas y Sociales, 1941. p. 111.

${ }^{62}$ BUEN, Nestor de apud NASCIMENTO, Amauri Mascaro. Curso de direito processual do trabalho, p. 105. 
utilizando-se dos ensinamentos de Carlos Coqueijo Costa e Ada Pelegrini Grinover ${ }^{63}$, conclui que, não sendo o processo um fim em si mesmo, deve adaptar-se à natureza do direito material que visa aplicar, sendo o seu único escopo a atuação da norma material e a tutela do direito violado.

Assim, é crucial que se compreenda que o princípio protetor no Direito Processual do Trabalho é um reflexo do caráter tutelar do Direito Material: mais uma vez Wagner D. Giglio $^{64}$ aponta que a busca de transformação social, inerente ao Direito do Trabalho, implica o reconhecimento da diferença entre as partes de um contrato de trabalho e a concessão de superioridade jurídica ao empregado destina-se a corrigir um desequilíbrio social. Ora, se tal diferença não desaparece no curso do processo judicial ${ }^{65}$, o Direito Processual do Trabalho deve manter o tratamento desigual entre as partes. Assim, percebese que o princípio protetor não é favorecimento arbitrário ao trabalhador - situação que violaria o contraditório e o devido processo legal - mas sim medida de justiça, destinada a recompor o equilíbrio entre as partes - reconhecido pela norma material do trabalho - e permitir que o processo se desenvolva em pé de igualdade. Nas palavras do professor ora citado, "o trabalhador é protegido pela lei, e não pelo juiz" "66.

Alguns dos mecanismos mais comumente apontados como destinados à proteção do trabalhador no plano processual trabalhista brasileiro são: a gratuidade das custas processuais em favor do trabalhador, havendo grande polêmica acerca do cabimento da concessão dos benefícios da justiça gratuita a empregadores, sejam pessoa física ou jurídica; os diferentes efeitos da ausência das partes em audiência una, uma vez que a ausência do reclamante gera meramente o arquivamento da ação, mas a do reclamado implica revelia e pena de confissão; a necessidade de depósito recursal para conhecimento de recurso do reclamado.

${ }^{63}$ COSTA, Carlos Coqueijo; GRINOVER, Ada Pelegrini apud GIGLIO, Wagner D.; CORRÊA, Cláudia Giglio Veltri. Direito Processual do Trabalho. São Paulo: Saraiva, 2005, p. 70.

${ }^{64}$ GIGLIO, Wagner D.; CORREA, Cláudia Giglio Veltri. Direito Processual do Trabalho, p. 75.

${ }^{65}$ Sarthou sustenta que existem três formas de desequilíbrio entre os litigantes que se apresentam de modo permanente e generalizado em um Processo Laboral: (i) econômica, caracterizada pela natureza das verbas em disputa, pois, enquanto para o empregador trata-se, em regra, de sua margem de lucro, para o trabalhador está em jogo o pagamento de créditos alimentares, cuja privação lhe é extremamente mais grave do que para o réu; (ii) probatória, uma vez que o empregador costuma ter a disponibilidade dos documentos relativos ao cumprimento do contrato de trabalho e mais facilidade para a indicação de testemunhas; e (iii) subjetiva, dado que a possibilidade de tomada de decisão do empregado é tolhida em especial pelas pressões econômicas decorrentes da urgência no recebimento de verbas alimentares, enquanto o empregador dispõe de liberdade plena na resolução que pretende dar ao conflito, pois tem menos a perder. Ver SARTHOU, Helious. Proposiciones sobre un derecho procesal laboral autónomo. Revista Derecho Laboral, Montevideo, t. XIX, n.101-104, 1976. p. 857.

${ }^{66}$ GIGLIO, Wagner D.; CORRÊA, Cláudia Giglio Veltri. Op. cit., p. 73. 
Nota-se, porém, que não se pode limitar a atuação do princípio protetor aos mecanismos expressamente previstos em lei, já que é um valor que deve permear completamente a atuação do juiz. Nesse sentido, Américo Plá Rodriguez diz que o caráter tutelar do Direito Processual do Trabalho revela-se em dois aspectos, um relativo à prova e outro relativo à atuação do juiz.

Pelo primeiro aspecto, sustenta, deve haver uma apreciação ampla e benevolente ${ }^{67}$ das provas produzidos pelo empregado e, embora isso não demande uma inversão do ônus da prova propriamente dita, deve haver redistribuição da carga da prova de acordo com a capacidade de cada parte para sua produção.

No Direito brasileiro, a questão da prova do trabalho é controvertida: sua regulamentação está no artigo 818 da CLT, o qual prevê que a prova das alegações incumbe à parte que as fizer, e, não obstante algumas vozes contrárias ${ }^{68}$, no artigo 333 do CPC - regras que não encontram nenhuma diferença do regime de provas do Processo Comum. Jorge Cavalcanti Boucinhas Filho ${ }^{69}$ afirma que tais dispositivos foram superados com o advento do artigo $6^{\circ}$, VII, do Código de Defesa do Consumidor, que prevê a inversão do ônus da prova com base na aptidão para sua produção e a sua aplicação subsidiária no Processo do Trabalho. Data venia, por mais louvável que seja a iniciativa do código consumerista, não se pode aí buscar o fundamento legal para a redistribuição do ônus probatório no Processo do Trabalho, sob pena de se cair em uma discussão técnica infrutífera sobre a aplicabilidade de tal norma, face ao artigo 769 da CLT, quando já existe permissão principiológica para tal redistribuição, que é o princípio protetor aplicado ao Direito Processual do Trabalho. Contudo, há que se concordar com a conclusão do referido autor, que defende a pertinência de previsão expressa, na norma processual trabalhista, de regra que preveja a inversão do ônus quando o reclamado detiver os meios necessários para a prova.

O segundo aspecto da aplicação geral do princípio protetor no Direito Processual do Trabalho, de acordo com o autor uruguaio, é a faculdade inquisitiva do juiz em matéria probatória. Essencialmente ligada à busca da verdade real, princípio que será visto a seguir, tal faculdade permite ao juiz investigar livremente as alegações feitas, não devendo se ater ao pedido das partes no tocante à produção de provas. A norma aplicável ao Processo do

\footnotetext{
${ }^{67}$ Carlos Henrique Bezerra Leite aponta que tal interpretação benevolente decorre da aplicação do princípio in dubio pro misero e consiste na possibilidade de, em caso de dúvida, interpretar a prova em favor da parte mais fraca - em regra, o empregado. Ressalta, porém, que esse princípio não é pacificamente aceito pela doutrina e pela jurisprudência. Ver BEZERRA LEITE, Carlos Henrique. Curso de direito processual do trabalho, p. 527 e 528.

${ }^{68}$ Ver TEIXEIRA FILHO, Manoel Antonio. A prova no processo do trabalho. São Paulo: LTr, 1986.

${ }^{69}$ BOUCINHAS FILHO, Jorge Cavalcanti. A inversão do ônus da prova no processo do trabalho. Disponível em: <http://jus2.uol.com.br/DOUTRINA/texto.asp?id=10176>. Acesso em: 17 dez. 2010.
} 
Trabalho brasileiro, nesse aspecto, é explícita, prevendo o artigo 765 da CLT que os Juízos e Tribunais do Trabalho têm ampla liberdade na direção do processo e devem velar pelo andamento rápido das causas, podendo determinar qualquer diligência necessária ao esclarecimento delas.

Ainda como consequência dessa faculdade inquisitiva do juiz, Américo Plá Rodriguez aponta a "suplencia que el juez deve llenar respecto de los errores, contradicciones u omissiones de la demanda"70. Apoiado na reforma processual levada a cabo no México, o autor defende que se justifica a possibilidade de correção da demanda laboral em virtude da natureza indisponível dos direitos trabalhistas e ao interesse público de que se aplique o Direito corretamente, bem como dos evidentes benefícios à administração da justiça, evitando-se a perpetuação dos conflitos judiciais pela propositura de diversas ações relativas ao mesmo contrato de trabalho.

Trata-se justamente do tema ora estudado, qual seja, a possibilidade de o juiz suprir ou corrigir a demanda do trabalhador e proferir sentença além ou diferentemente do formulado na inicial, violando-se, portanto, o princípio da congruência entre pedido e sentença. Neste momento, não interessa detalhar os diversos benefícios e dificuldades que podem surgir dessa possibilidade, mas apenas demonstrar que a aplicação do princípio protetor no Processo do Trabalho não se limita às possibilidades já conhecidas e praticadas e também pode levar à quebra de dogmas processuais tradicionalmente construídos e mantidos sem que se quebre a harmonia do sistema processual trabalhista.

\subsubsection{Busca da Verdade Real}

A busca da verdade real, de acordo com Américo Plá Rodriguez, é um reflexo do princípio da primazia da realidade que, no plano material, garante os direitos do trabalhador cuja relação de trabalho atenda os requisitos previstos no artigo $3^{\circ}$ da CLT, mesmo que essa relação de emprego não seja formalizada ou que alguns elementos dela tenham sido dissimulados. É, portanto, verdadeiro mecanismo de proteção ao trabalhador, que muitas vezes vê-se obrigado a firmar contratos diversos dos de emprego e sem a proteção a este inerente, mas que, na prática, desempenha atividades habituais, onerosas, pessoais e subordinadas. Tal é o caso, por exemplo, de cooperativas de trabalho fraudulentas, em que os cooperados sequer participam das decisões da associação, prestando serviço diretamente para o tomador de serviços.

\footnotetext{
${ }^{70}$ PLÁ RODRIGUEZ, Américo. Princípios de Direito do Trabalho, p. 247.
} 
No plano processual, tal busca permite que se identifique a verdadeira natureza do conflito levado a juízo, de modo que se dê a resposta jurídica mais adequada para solucioná-lo. Como exposto no item 2.2, a máxima aproximação da identificação entre conflito social e conflito jurídico é essencial para que se alcance a harmonização da sociedade, de modo que uma investigação judicial que forneça aos autos elementos reais e não meramente formais - da relação discutida atende muito mais aos escopos do Processo (Geral e Trabalhista) do que uma atuação limitada a questões formais e documentais.

Deste modo, a busca da verdade real no Processo do Trabalho apresenta-se sob dois aspectos diferentes. Em primeiro lugar, pela possibilidade de desconstituição de prova escrita por prova testemunhal, havendo quem defenda que tal prevalência se dá apenas quando a prova escrita é contraditória ${ }^{71}$, enquanto outros defendem a primazia da prova testemunhal sobre a documental sem ressalvas objetivas ${ }^{72}$, apenas embasado no poder de livre convencimento do juiz. Trata-se, decerto, de evidente diferença entre o Processo do Trabalho e o Comum, pois, embora neste já se tenha abolido o instituto da prova legal, ainda se encontram no CPC dispositivos que preveem a prova unicamente documental, como é o caso de contratos com valor acima de dez salários mínimos (artigo 401).

O segundo desdobramento do princípio ora analisado é a estrutura inquisitiva do Processo do Trabalho, permitindo-se ao juiz a ampla iniciativa investigatória acerca das provas, sendo-lhe lícito, no Direito brasileiro, como já exposto acima, a determinação de qualquer diligência para esclarecimento da causa. Tal possibilidade é crucial para suprir a deficiência probatória do empregado, sem que se viole o princípio da imparcialidade do juiz. De fato, ao se conceder tal poder ao juiz - e instituir o esclarecimento da verdade real como um dever - afasta-se qualquer denúncia no sentido de que o Judiciário Trabalhista

\footnotetext{
${ }^{71}$ Horas extras. Prevalência da prova testemunhal sobre a prova documental. Se o conjunto probatório evidencia que a maioria dos cartões de ponto acostados aos autos encontra-se sem a assinatura do obreiro $e$, além disso, consigna marcação invariável do horário de trabalho, não espelhando a realidade fática, patente a fragilidade dos documentos em questão, razão pela qual, deve prevalecer a prova testemunhal produzida, que corrobora o horário declinado na exordial. TRT/SP, Recurso Ordinário no $02940427440,6^{\text {a }}$ Turma, Juiz-Relator Amador Paes de Almeida, 1996.

${ }^{72}$ Comparação entre a prova oral e a documental. Princípio da primazia da realidade. Não se pode dizer que a prova oral é fraca, pois o princípio primazia da realidade informa que se deve prestigiar a realidade dos fatos em detrimento da forma empregada pela empresa. Os fatos indicam que a reclamante não gozou férias. Devem, portanto, ser observados em relação aos documentos, que são confeccionados pela própria empresa. $O$ artigo 400 do CPC se aplica ao processo civil, mas não no processo do trabalho, em que o empregado não tem condições de produzir prova documental sobre documentos que estão em poder do empregador. Logo, só pode produzir prova testemunhal. Esta foi contemporânea aos fatos, foi conclusiva no sentido de que o reclamante não gozou férias. Assim, deve ser observada, até porque todos os meios legais, bem como os moralmente legítimos, ainda que não especificados no CPC, são hábeis para provar a verdade dos fatos, em que se funda a ação (art. 332 do CPC). A prova documental já foi valorada diante da prova testemunhal, que prevaleceu, por refletir a primazia da realidade. TRT/SP, Recurso Ordinário $\mathrm{n}^{\circ}$ 20000288718, 3ª Turma, Juiz-Relator Sérgio Pinto Martins, 2001.
} 
serve aos interesses dos empregados e que o juiz "toma partido" em favor dos trabalhadores. O que se observa é que a desconstituição das provas formais, em geral, favorece o empregado, uma vez que a prova documental costuma ser produzida pelo empregador, que tem os meios - ilegais, diga-se de passagem - de inserir o conteúdo que mais lhe convém, dissimulando a realidade. Isso não significa, contudo, que o princípio da primazia da realidade não possa favorecer o empregador, se assim indicarem os fatos.

Por fim, cumpre ressaltar que o princípio da busca da verdade real é característico não apenas do Direito Processual do Trabalho, mas do Direito Processual Penal. Além de servir à pacificação da sociedade, pela aproximação da resolução do conflito social e jurídico - escopo do processo em geral - nesses dois ramos do Direito Processual, o princípio aqui estudado visa resguardar direitos indisponíveis: direitos alimentares no primeiro caso e a liberdade no segundo. Como se verá a seguir, a indisponibilidade dos direitos trabalhistas é a terceira característica apontada por Américo Plá Rodriguez como princípio exclusivo do Processo do Trabalho.

\title{
2.4.3 Indisponibilidade
}

Para Américo Plá Rodriguez, é no princípio da indisponibilidade que reside a principal diferença entre o Direito Processual Trabalhista e o Direito Processual Comum. Há pontos de contato entre os dois tipos de processo no que diz respeito ao interesse pela celeridade, economia e realismo, mas a relativização do princípio dispositivo se verifica com mais relevância no Processo do Trabalho, em razão justamente da irrenunciabilidade do Direito Material Trabalhista, derivada de seu caráter alimentar e de norma de ordem pública (artigo $9^{\circ}$ da CLT). Diz Sussekind que

\begin{abstract}
são irrenunciáveis os direitos que a lei, as convenções coletivas, as sentenças normativas e as decisões administrativas conferem as trabalhadores, salvo se a renúncia for admitida por norma constitucional ou legal ou se não acarretar uma desvantagem para o trabalhador ou um prejuízo à coletividade ${ }^{73}$.
\end{abstract}

No Processo Comum, ao contrário, as partes gozam de maior liberdade para transigir ou mesmo desistir de seus direitos. De modo aproximado, sustenta Ada Pelegrini Grinover que "esse poder dispositivo é quase absoluto no processo civil, mercê da natureza do direito material que se visa a atuar. Sofre limitação quando o direito material é de natureza indisponível, por prevalecer o interesse público sobre o privado" ${ }^{\text {74 }}$.

\footnotetext{
${ }^{73}$ SUSSEKIND, Arnaldo et al. Instituições de direito do trabalho. São Paulo: LTR, 2000. p. 216.

${ }^{74}$ GRINOVER, Ada Pelegrini. O Processo Constitucional em marcha. São Paulo: Max Limonad, 1985. p. 61.
} 
Há que se reconhecer, contudo, que a aplicação do princípio da indisponibilidade não é totalmente ausente no Processo Comum, como nos casos que envolvem Direito de Família. Tal princípio, ainda, mostra-se ainda mais atuante no Processo Penal, em que a propositura das ações penais públicas independe da vontade das partes, sendo realizada de ofício pela autoridade ministerial. Para o início do Processo do Trabalho, contudo, é necessária a provocação do órgão jurisdicional pela parte interessada, existindo, porém, uma verdadeira relativização desta necessidade no artigo 39 da CLT, que prevê o envio à Justiça do Trabalho, pelo órgão administrativo, de procedimento administrativo relativo à anotação de contrato de trabalho. Tal hipótese, ressalta-se, não é uma exceção, apenas uma relativização, uma vez que o início do procedimento administrativo depende, nos termos do artigo 36 da CLT, de iniciativa do empregado.

Feita a devida ressalva, não é erro prosseguir com a afirmação de que o princípio da indisponibilidade vigora no Processo do Trabalho, devendo o juiz utilizar-se dos mecanismos disponíveis no ordenamento jurídico para garantir não apenas que o processo seja efetivo - valendo-se, por exemplo, do poder investigatório acerca das provas e da execução de ofício -, mas também assegurar que o empregado não disponha de direitos irrenunciáveis, uma vez que a natureza fundamental desses direitos não se transmuda em disponível em juízo, ao contrário do que a prática tem demonstrado ${ }^{75}$. Ana Farias Hirano sustenta que o juiz deve, quando da tentativa de conciliação, atentar para os direitos pleiteados e as controvérsias trazidas pela contestação, abstendo-se de homologar acordos que importem em renúncia de direitos indisponíveis. Trata-se de uma postura absolutamente defensável, posto que, se por um lado o juiz não pode favorecer uma das partes, por outro deve zelar pelo bom andamento do processo e a sua correta utilização, destinada a tornar efetivo o Direito Material.

Contudo, é possível ir além. Américo Plá Rodriguez defende ainda que é dever do magistrado "advertir que el actor no ha reclamado todo a lo que tiene derecho. Sea por error, por omisión, por desconocimiento, por falta de estudio en la preparación de la demanda, o por lo que fuere" ${ }^{, 76}$. Embora tal sugestão soe uma violação ao princípio da

\footnotetext{
${ }^{75}$ Em pesquisa de campo, Ana Farias Hirano observou que a prática de conciliação na Justiça do Trabalho, em boa parte, ignora a natureza dos direitos pleiteados, sendo realizados acordos que importam em verdadeira renúncia a direitos indisponíveis. A título de exemplo, podem ser citados casos em que, não obstante o reconhecimento de relação de emprego, por parte da empresa, foram homologados acordos sem o reconhecimento do vínculo empregatício. Ver HIRANO, Ana Farias. Acordos Homologados pela Justiça do Trabalho: Transação de Direitos Controvertidos ou Renúncia a Direitos Indisponíveis?

${ }^{76}$ PLÁ RODRIGUEZ, Américo. Princípios de Direito do Trabalho, p. 253.
} 
parcialidade do juiz, há, em ordenamentos jurídicos semelhantes ao brasileiro, previsão dessa assistência. Na lei trabalhista mexicana, o artigo 685 estabelece que

\begin{abstract}
el proceso del derecho del trabajo será público, gratuito, inmediato, predominantemente oral y se iniciará a instancia de parte. Las Juntas tendrán la obligación de tomar las medidas necesarias para lograr la mayor economía, concentración y sencillez del proceso. Cuando la demanda del trabajador sea incompleta, en cuanto a que no comprenda todas las prestaciones que de acuerdo con esta Ley deriven de la acción intentada o procedente, conforme a los hechos expuestos por el trabajador, la Junta, en el momento de admitir la demanda, subsanará esta. Lo anterior sin perjuicio de que cuando la demanda sea obscura o vaga se proceda en los términos previstos en el artículo 873 de esta Ley $^{77}$.
\end{abstract}

Ora, tal disposição normativa está a apenas um pequeno passo da ideia de julgamento ultra e extra petita, situação consentida por Américo Plá Rodriguez na hipótese de o juiz perceber que houve omissão de pedido relacionado a direito irrenunciável. Mário Pasco, por sua vez, admite a relativização do princípio da congruência não apenas como medida de proteção aos direitos irrenunciáveis do trabalhador, mas também em favor dos princípios da economia processual e da realidade ${ }^{78}$. Eduardo Stafforini sustenta que o princípio da congruência é próprio do Direito Processual Comum, não se aplicando ao Processo Trabalhista: neste caso, o juiz não ficaria adstrito ao que foi alegado e provado ${ }^{79}$. Como se verá no Capítulo 3, uma das polêmicas acerca da aplicação do princípio da congruência refere-se justamente ao fato de que estar tal princípio previsto no CPC, havendo-se que ponderar se realmente é compatível com as normas processuais trabalhistas e, portanto, passível de aplicação subsidiária, nos termos do artigo 769 da CLT. Apesar de ser opinião minoritária na doutrina nacional, Wagner D. Giglio ${ }^{80}$ defende que o reconhecimento do princípio da extrapetição é uma tendência atual, destinada ao aprimoramento do Direito Processual Laboral.

Diante de todo o exposto, nos próximos capítulos analisar-se-á a aplicação do princípio da congruência no processo, em geral, e no Processo do Trabalho, em especial, levando-se em conta os escopos do processo, o papel do Estado na proteção dos direitos fundamentais e os princípios que regem o Processo Trabalhista.

\footnotetext{
${ }^{77}$ Disponível em: <http://www.cddhcu.gob.mx/LeyesBiblio/pdf/125.pdf>. Acesso em: 20 jun. 2010. Grifos ausentes no original.

${ }^{78}$ PASCO, Mário apud PLÁ RODRIGUEZ, Américo. Princípios de Direito do Trabalho, p. 253-254.

${ }^{79}$ STAFFORINI, Eduardo. Derecho procesal social. Buenos Aires: TEA, 1955. p. 34.

${ }^{80}$ GIGLIO, Wagner D.; CORRÊA, Cláudia Giglio Veltri. Direito Processual do Trabalho, p. 74.
} 


\section{PRINCÍPIO DA CONGRUÊNCIA}

\subsection{Questões Preliminares}

O princípio da congruência é um dogma. A mera consideração de tal questão como um princípio carrega, por si só, a sua força. É certo que se trata de um dos mais conhecidos dogmas do Processo Civil, cujas nomenclaturas variam entre "princípio da correlação entre ação e sentença" ${ }^{\circ 1}$, "regra da correspondência entre sentença e pedido", 82 "convergência entre as sentenças e as ações" 83 ou "princípio da adstrição" cujas definições mais frequentes são "proibição de julgamento ultra, extra e citra petita" e "julgamento nos limites da lide".

Um cuidadoso estudioso do Direito notará que todos esses supostos sinônimos e correspondentes conceitos apresentam uma miríade de institutos semânticos e jurídicos diferentes. Apesar disso, na prática, referem-se a apenas um fenômeno, o qual, em um primeiro momento, será indicado como uma limitação ao poder do juiz, que deve ficar adstrito ao pleiteado na petição inicial quando do proferimento da sentença: não pode conceder nada que vá além ou que seja diferente do pedido, nem deixar de apreciar pedido. Frisa-se, contudo, que tal indicação é temporária e será explorada neste capítulo.

Considerando que a proposta deste trabalho não é uma mera investigação da aplicação de uma norma processual, mas a nomenclatura, conceituação, entendimento e uso de um instituto jurídico, o objetivo deste capítulo é aliar a pesquisa doutrinária a uma crítica das premissas normalmente utilizadas para tratar desse assunto, as quais muitas

\footnotetext{
${ }^{81}$ ARAÚJo CINTRA, Antônio Carlos. Comentários ao Código de Processo Civil. Rio de Janeiro, Forense, 2008. p. 290.

${ }^{82}$ ALVIM ARRUDA, José Manuel de. Manual de direito processual civil. v. 2. São Paulo: Revista dos Tribunais, 2008. p. 667.

${ }^{83}$ Idem. Dogmática jurídica e o novo código de processo civil. Revista de Processo Civil, ano I, n. 1, p. 85133, jan./mar. 1976. p. 93.

${ }^{84}$ BEDAQUE, José Roberto dos Santos et al. Código de Processo Civil interpretado. São Paulo, Atlas, 2005. p. 390.
} 
vezes passam de professor a aluno, advogado a estagiário, de juiz para sentença, sem o devido questionamento, perpetuando uma ideia deslocada da realidade. Assim, em um primeiro momento, tratar-se-á dos aspectos linguísticos e semânticos do uso comum dos termos mais frequentes no estudo do princípio da congruência.

Tal estudo justifica-se por dois motivos: (i) Tercio Sampaio Ferraz Junior diz que o uso de termos no âmbito do Direito oscila entre o uso comum das palavras (onomasiológico) e o uso normativo (semasiológico), que dá o sentido técnico das palavras. O mesmo autor diz que este sentido "não é absolutamente independente, mas está ligado de algum modo ao sentido comum, sendo, por isso, passível de dúvidas que emergem da tensão de ambos" ${ }^{\$ 85}$. Ora, à primeira vista, é possível notar que existe uma diferença no uso comum de palavras como "congruência", "correlação" e "adstrição", mas se todas possuem o mesmo sentido jurídico, algo em comum devem ter para os estudiosos do Direito terem-lhes escolhido para designar o mesmo instituto. Assim, apenas dando um passo para trás, ou seja, buscando o uso primeiro das palavras, é que se poderá ter uma ideia do que se quis dizer com todas essas expressões; (ii) além dessa primeira justificativa, aplicada a todo e qualquer estudo acadêmico do Direito, pensar no significado, precisão e alcance das palavras é justamente o que o advogado faz quando elabora a petição inicial ou quando contesta e o que o juiz exercita quando profere a sentença, sendo que, no último caso, dependendo do significado, precisão e alcance que der às palavras apresentadas pelas partes, poderá incorrer em decisão ultra ou extra petita $^{86}$. Deste modo, este subitem é também um exercício que deve ser feito com cuidado, pois a imperícia ou o desleixo, a princípio, podem implicar a preclusão de um direito, a nulidade de uma sentença, a ineficácia de uma norma, a inefetividade do processo: uma injustiça.

De acordo com o Dicionário Houaiss de Língua Portuguesa ${ }^{87}$, tem-se:

\footnotetext{
${ }^{85}$ FERRAZ JUNIOR, Tercio Sampaio. Introdução ao estudo do direito, p. 251.

${ }^{86} \mathrm{O}$ problema da linguagem já foi identificado por Paulo de Tarso Ramos Ribeiro: “Até porque, a noção de 'escravo da lei' como muitas vezes têm-se declarado magistrados no país é, no mínimo ilusória, sobretudo quando se tem em conta os impasses hermenêuticos em que se vêem enredados os juristas exatamente pela impossibilidade, já apontada, pela lingüística e semiologia modernas, do emprego rigoroso e unívoco da linguagem natural na definição dos conceitos jurídicos". Ver RIBEIRO, Paulo de Tarso Ramos. Processo e Conflito: a crise de legitimação das decisões judiciais. Revista de Direito Alternativo, São Paulo, n. 1, p. 77-94, 1992. p. 78.

${ }^{87}$ HOUAISS, Antônio; VILLAR, Mauro de Salles. Dicionário Houaiss da Língua Portuguesa. Elaborado pelo Instituto Antônio Houaiss de Lexicografia e Banco de Dados da Língua Portuguesa. Rio de Janeiro: Objetiva, 2009. CD-ROM.
} 
Tabela 1 - Significados

\begin{tabular}{|c|c|}
\hline Palavra & Significado \\
\hline Congruência & $\begin{array}{l}\text { i. Qualidade do que é congruente; coincidência ou } \\
\text { correspondência de caráter ou qualidades; conformidade, } \\
\text { concordância, harmonia; } \\
\text { ii. Identidade ou correspondência constitucional ou estrutural } \\
\text { (que possibilita a união ou a mistura de uma coisa com } \\
\text { outra[s]); } \\
\text { iii. Adequação, justeza, aptidão ao fim a que se propõe ou se } \\
\text { destina; } \\
\text { iv. Ponto de concordância, correspondência etc; } \\
\text { v. Relação harmônica das partes de um todo; coerência, } \\
\text { conformidade, identidade com algo; concordância com as } \\
\text { circunstâncias, fatos etc.; } \\
\text { Propriedade, exatidão ou correção gramatical no exprimir- } \\
\text { vi. }\end{array}$ \\
\hline Correspondência & $\begin{array}{l}\text { i. Ato, processo ou efeito de corresponder (-se), de apresentar } \\
\text { ou estabelecer reciprocidade; } \\
\text { ii. Similitude, analogia existente entre pessoas ou coisas ou } \\
\text { ideias; } \\
\text { iii. Relação perfeita, harmônica; } \\
\text { iv. Rubrica: matemática. Regra por meio da qual cada elemento } \\
\text { de um conjunto é associado a um ou mais elementos de } \\
\text { outro conjunto. }\end{array}$ \\
\hline Adstrição & $\begin{array}{ll}\text { i. } & \text { Ato de comprimir (-se) [algo]; atar (-se), estreitar (-se); } \\
\text { ii. } & \text { Ato de impor (-se) limites; limitar-se, restringir-se. }\end{array}$ \\
\hline Correlação & $\begin{array}{l}\text { i. Correspondência, similitude, analogia entre pessoas, coisas, } \\
\text { ideias etc. relacionadas entre si; } \\
\text { ii. Rubrica: geometria. Transformação que associa, no plano, } \\
\text { pontos a linhas e linhas a pontos, e, no espaço, associa } \\
\text { pontos a planos e planos a pontos. }\end{array}$ \\
\hline Convergência & $\begin{array}{l}\text { i. Disposição de dois ou mais elementos lineares que se } \\
\text { dirigem para ou se encontram no mesmo ponto; } \\
\text { ii. Derivação: sentido figurado. tendência para aproximação ou } \\
\text { união em torno de um assunto ou de um fim comum; } \\
\text { confluência, concorrência; } \\
\text { iii. Rubrica: física. Propriedade de um sistema de partículas ou } \\
\text { de um feixe de radiação cujas trajetórias ou raios convergem } \\
\text { para um único ponto; } \\
\text { iv. Rubrica: geometria. Propriedade das retas que tendem para o } \\
\text { mesmo ponto. }\end{array}$ \\
\hline
\end{tabular}

Da breve observação do sentido das palavras acima, percebe-se que, embora utilizadas como sinônimos na esfera jurídica - pelo menos no que concerne ao princípio ora estudado -, elas encerram significados diversos. Assim, enquanto congruência, correspondência e correlação se voltam para a ideia de conformidade e adequação, com uma variação entre similitude e identidade, adstrição, por si só, apenas diz respeito à 
imposição de limites, sem indicar os elementos identificadores de tais limites, e convergência afasta-se ligeiramente dos três primeiros termos ao indicar simplesmente a tendência de um movimento em direção a um fim comum.

Está clara, portanto, a origem da costumeira incompreensão do princípio da congruência. Inexiste uma positivação normativa da nomenclatura de tal instituto, ficando a cargo da doutrina e da jurisprudência indicar-lhe o nome, de acordo com a ideia que lhes pareça mais conveniente. Assim, um estudioso mais preocupado com a imposição de limites à atividade jurisdicional, irá adotar o nome princípio da adstrição, ao passo que alguém com vistas mais ao conteúdo da ação e ao fim do processo estará mais inclinado à adoção dos termos congruência, correspondência e correlação, que remetem menos a limites e mais a adequação. Escolheu-se utilizar o termo congruência neste trabalho por se entender ser o mais preciso, em especial se tomado como "adequação, justeza, aptidão ao fim a que se propõe ou se destina". Ora, não há dúvidas de que esse sentido é o mais próximo do que se procura dar a todo o processo, sob a ótica da instrumentalidade, como foi visto no capítulo anterior. Não há mal em repetir as palavras de José Roberto dos Santos Bedaque, que sustenta que "o direito processual deve adaptar-se às necessidades específicas de seu objeto, apresentando formas de tutela e de procedimento adequadas às situações de vantagem asseguradas pela norma substancial" ${ }^{88}$. É certo, então, que é incompatível com o processo moderno a noção de limitar pura e simplesmente a atuação do juiz, sem levar em consideração o conteúdo da demanda (princípio da adstrição) ou a ideia de exigir-se, inexoravelmente, identidade entre os termos da demanda e do provimento.

Por outro lado, os dois conceitos mais comuns deste princípio e aqui selecionados também merecem atenção:

(i) proibição de julgamento ultra, extra ou citra petita: expressões em latim costumam ser a coqueluche de muitas peças jurídicas e o atual desconhecimento da língua as torna ainda mais enigmáticas; seu sentido raramente é depreendido do significado comum das palavras que as compõem e, em geral, provém de explicações encontradas na doutrina, que se repetem sem muita ordem. No Dicionário Escolar Latino-Português, à palavra petita é dado o sentido de pedido e de petição, este último significado também é encontrado como sinônimo de petitio, cujos outros sentidos jurídicos são requerimento, reclamação, instância (em juízo) ${ }^{89}$.

\footnotetext{
${ }^{88}$ BEDAQUE, José Roberto dos Santos. Direito e Processo, p. 23.

${ }^{89}$ FARIA, Ernesto. Dicionário Escolar Latino-Português. Rio de Janeiro: Campanha Nacional de Material de Ensino, 1956. p. 718 e SOUSA, Francisco Antônio. Novo dicionário Latino-Português. Porto: Lello \& Irmão, 1984. p. 731.
} 
Nota-se, portanto, que, se por um lado petita pode corresponder exatamente a pedido, por outro pode ser entendida de um modo mais amplo, como toda a petição. Conforme foi visto no Capítulo 2, o pedido constitui o objeto do processo, mas com ele não se confunde. O estudioso do Direito Processual sabe que os elementos identificadores de uma demanda são, além do pedido, as partes e a causa de pedir. Ou seja, a forma de uma petição não é definida pura e simplesmente pelo pedido, mas também por outros elementos, de modo que a identificação de petita como pedido ou como petição encerra muito mais do que uma escolha linguística, refletindo diretamente na atuação judicial. Isso porque os adjetivos que acompanham o termo petita ora poderão ser entendidos com além $^{90}$ (ultra), fora ${ }^{91}$ (extra) ou aquém ${ }^{92}$ (citra) do pedido ou da petição (que compreende, além do pedido, a causa de pedir e as partes).

(ii) julgamento nos limites da lide: limite, mais uma vez de acordo com o Dicionário Houaiss ${ }^{93}$, é “(1) linha que determina uma extensão espacial ou que separa duas extensões; linha de demarcação; raia; (2) o que determina, marca os contornos de um domínio abstrato ou separa dois desses domínios". Entende-se, portanto, que, ao se falar de limites, se está considerando a existência de um espaço dentro do qual, dependendo do seu tamanho, é possível ir e vir sem atingir suas margens. Isso significa dizer que o julgamento dentro dos limites da lide - considerando-se lide como o pedido do processo - não implica, necessariamente, a identidade absoluta da sentença e do pedido, podendo haver discricionariedade do juiz na redação da sentença, desde que se mantenha dentro desse “espaço" delimitado pelo pedido. Graficamente, tem-se o seguinte:

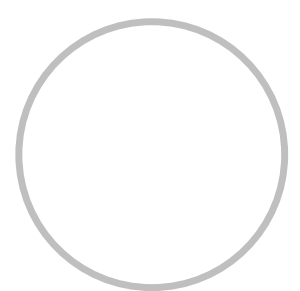

Figura 1

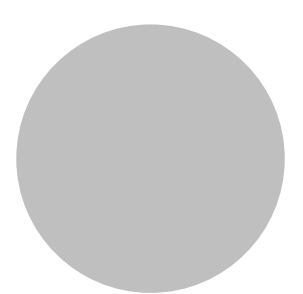

Figura 2

Ambas as figuras representam a lide, sendo que seus limites estão delimitados pela circunferência e as áreas escurecidas correspondem à matéria sobre a qual é lícito ao juiz decidir, dependendo do que se entende pelo princípio da congruência. A Figura 1 é

\footnotetext{
${ }^{90}$ FARIA, Ernesto. Dicionário Escolar Latino-Português, p. 998.

${ }^{91}$ Ibidem, p. 364.

92 Ibidem, p. 180.

${ }^{93}$ HOUAISS, Antônio; VILLAR, Mauro de Salles. Dicionário Houaiss da Língua Portuguesa. CD-ROM.
} 
representativa do entendimento de que ao juiz é possível deferir os pedidos apenas nos exatos termos propostos (identidade entre pedido e sentença), enquanto a Figura 2 representa a interpretação de que se permite ao juiz decidir dentro de todo o círculo delimitado pelo pedido. A título de exemplo - e adiantando o que se verá no Capítulo 4 por diversas vezes o Tribunal Superior do Trabalho entendeu ser legal a decisão que reconhece a responsabilidade subsidiária de tomadora de serviços com base em sua Súmula 331, ainda que o pedido tenha sido de condenação em responsabilidade solidária, baseado na mesma súmula. Tal possibilidade já era vislumbrada por Francisco Cavalcanti Pontes de Miranda que dizia: "mas, por vezes, pedindo-se mais, há-se de entender o pedido o menos" 94 .

Conclui-se, deste modo, que o princípio da congruência, em suas mais variadas nomenclaturas e conceitos, prevê uma relação de adequação entre o pretendido pelo autor e a sentença, não exigindo uma coincidência literal e estrita entre os termos da sentença e os da petição ou mesmo do pedido. Tal é a conclusão que se pode tirar da terminologia usualmente utilizada pela doutrina e pela jurisprudência para tratar deste assunto; no próximo item, será analisado o fundamento legal do tema ora estudado, de modo a verificar se a conclusão da leitura terminológica é congruente com o que se depreende da leitura legal.

\subsection{O Princípio da Congruência e sua Relação com Outros Princípios}

A vida social é marcada pela imprevisibilidade e reunir condições de se precaver dos infortúnios do destino tem sido uma das principais preocupações do homem - se não a principal delas. Não à toa, o princípio da segurança das relações sociais permeia os ordenamentos jurídicos modernos, em que há expressa proteção ao direito adquirido, à coisa julgada e ao ato jurídico perfeito.

Em relação ao Direito Processual, a segurança é resguardada por diversos institutos, sendo que interessa, para este trabalho, o princípio da congruência entre o pedido e a sentença, tradicionalmente indicado nos artigos 128 e 460 do CPC, combinados com o artigo 293 do mesmo diploma, dispositivo que determina a interpretação restritiva dos pedidos. Antes de se passar à análise específica desses dispositivos legais, cabe uma ligeira digressão histórica.

\footnotetext{
${ }^{94}$ PONTES DE MIRANDA, Francisco Cavalcanti. Comentários ao Código de Processo Civil. São Paulo:
} Forense, 1974. p. 356. 
A proibição do julgamento extra, ultra e citra petita baseia-se em um princípio do Direito romano: ne eat judex ultra petita partium. As Antigas Ordenações previam apenas limitação ao pedido principal do autor, mas aceitavam a interpretação extensiva em relação aos acessórios, custas e frutos do capital ${ }^{95}$. Ao pronunciar-se sobre tal dispositivo, José Antônio Pimenta Bueno indica que o julgamento além, fora ou aquém do pedido importa em nulidade da sentença, sustentando que "o julgador deve dar a sentença conforme o que se acha alegado e provado nos autos, ainda que a consciência lhe dite outra coisa, e ele saiba a verdade em contrário" 96.

Já o Código Civil de 1939, em seu artigo $4^{\circ}$ dispunha que o "juiz não poderá pronunciar-se sobre o que não constitua objeto do pedido, nem considerar exceções não propostas para as quais seja por lei reclamada a iniciativa da parte". De modo exemplar, Francisco Cavalcanti Pontes de Miranda começa a se afastar da rigidez do período anterior e sustenta que, embora o juiz esteja de fato adstrito ao objeto do pedido, tal objeto é o todo material e jurídico da petição ${ }^{97}$. Nota-se, portanto, que o julgamento do autor sobre o termo petita não se limita ao sentido estrito de pedido, mas estende-se à ideia mais ampla de petição, como exposto no item anterior.

No atual Código de Processo Civil, o princípio da congruência costuma ser indicado no artigo 128 - "O juiz decidirá a lide nos limites em que foi proposta, sendo-lhe defeso conhecer de questões, não suscitadas, a cujo respeito a lei exige a iniciativa da parte" - e no artigo 460 - "É defeso ao juiz proferir sentença, a favor do autor, de natureza diversa da pedida, bem como condenar o réu em quantidade superior ou em objeto diverso do que lhe foi demandado”. Também não se pode deixar de fazer referência ao artigo 293, que estabelece: - "Os pedidos são interpretados restritivamente, compreendendo-se, entretanto, no principal os juros legais".

$\mathrm{Na}$ legislação processual trabalhista, não há referência expressa ao princípio da congruência, sendo que os dispositivos do Processo Civil lhe são aplicados por força do artigo 769 da CLT. Sobre esse ponto, cabe uma breve observação: o artigo 769 da CLT determina ser aplicável ao Processo Trabalhista a legislação processual comum nos casos de omissão, desde que haja compatibilidade com as normas laborais. O que se observa, de modo quase generalizado, é a aceitação passiva da aplicação dos artigos 128 e 460 do

\footnotetext{
95 PIMENTA BUENO, José Antônio. Apontamentos sobre as formalidades no Processo Civil. Rio de Janeiro: Typographia Nacional, 1858. p. 108.

${ }^{96}$ Ibidem, p. 88.

${ }^{97}$ PONTES DE MIRANDA, Francisco Cavalcanti. Comentários ao Código de Processo Civil, p. 354.
} 
$\mathrm{CPC}^{98}$, sem que haja uma discussão aprofundada sobre duas questões muito importantes: (i) a CLT é acidental ou propositadamente omissa em relação ao princípio da congruência?; e (ii) os artigos 128 e 460 são compatíveis com o Processo do Trabalho?

Nesta dissertação, até mesmo por um motivo metodológico, considerar-se-á o princípio da congruência aplicável ao Processo do Trabalho, mas as perguntas acima formuladas têm uma razão de ser: o Processo do Trabalho é marcado pela informalidade, cujos traços mais expressivos são a possibilidade de apresentar a reclamação trabalhista oralmente e a simplicidade da petição inicial escrita, que, nos termos do artigo $840, \S 1^{\circ}$, da CLT, deve conter apenas uma breve exposição dos fatos e o pedido, de modo que a exigência de uma sentença que se atenha estritamente ao contido na exordial não parece se coadunar com tais características. Ademais, a evidente hipossuficiência do trabalhador frente ao empregador e o caráter de ordem pública das normas trabalhistas não deixam de ser incentivos para que o juiz ultrapasse os limites da inicial, se tal atitude for necessária para tornar efetivos os direitos trabalhistas. Nesta mesma linha, a compatibilidade dos artigos civilistas com a legislação processual trabalhista não é automática: se se considerar a existência de uma identidade axiológica entre o ordenamento processual trabalhista brasileiro e os demais da América Latina, observar-se-á que a ultrapetitividade é regra positivada em muitos sistemas ${ }^{99}$ ! A partir desta argumentação, Christiane Moura Velho

\footnotetext{
${ }^{98}$ Carlos Henrique Bezerra Leite, por exemplo, sequer expõe a base legal da aplicação dos artigos 128 e 460 do CPC ao processo do trabalho. Ver BEZERRA LEITE, Carlos Henrique. Curso de direito processual do trabalho, p. 612 e 613.

${ }^{99}$ O Código Geral de Processo do Uruguai (Lei no 15.982) dispõe: Artigo. 350.3 "En las pretensiones propias de la materia laboral, agraria y demás de carácter social, no obstante lo dispuesto en el numeral $1^{\circ}$ del artículo 341, se podrá modificar la pretensión en la audiencia preliminar, cuando resulte, manifiestamente, que carencias de información o de asesoramiento han determinado omisiones en relación a derechos que asisten a la parte. En estos casos, el tribunal otorgará a la contraparte oportunidades para la adecuada contestación; se podrá a tales efectos, prorrogar la audiencia, si las nuevas cuestiones son de hecho y no fuere posible controvertirlas, sin previa información". URUGUAI. Código General del Proceso. Ley 15.982/1988. Disponível em: <http://www.parlamento.gub.uy/leyes/AccesoTextoLey.asp? Ley=15982\&Anchor=>. Acesso em: 17 dez. 2010. No Código de Trabalho da Nicarágua (Lei $\mathrm{n}^{\circ}$ 185), o art. 266, j, consagra o princípio da "ultrapetitividad cuando se puden reconocer prestaciones no pedidas em la demanda". NICARAGUA. Código del Trabajo. Ley 185/1996. Disponível em: <http://www.ilo.org/dyn/natlex/docs/WEBTEXT/ 45784/65050/S96NIC01.htm\#12t1c1]>. Acesso em: 17 dez. 2010. O Código de Processo de Trabalho do Paraguai (Lei $\mathrm{n}^{\circ}$ 742), em seu artigo 229 diz: "El juez podrá en la sentencia: a) Ordenar el pago de salarios, prestaciones o indemnizaciooes mayores que las pedidas por el trabajador, supliendo la omisión de éste, cuando quedare demostrado que son inferiores a las que le corresponden de conformidad con la ley, y siempre que no hayan sido pagadas; y b) Aunque el trabajador no lo pida, condenar al empleador cuando esté debidamente probado en juicio que no ha dado cumplimiento a obligaciones legales o contractuales". PARAGUAI. Código Procesal del Trabajo. Ley 742/1961. Disponível em: <http://www.senado.gov.py/ leyes/?pagina=ley_resultado\&id=3919]>. Acesso em: 17 dez. 2010. Dispõe o Código Processual de Trabalho da Colômbia (Lei 2158), em seu artigo 50: "EXTRA Y ULTRA PETITA. El Juez podrá ordenar el pago de salarios, prestaciones o indemnizaciones distintos de los pedidos, cuando los hechos que los originen hayan sido discutidos en el proceso y estén debidamente probados, o condenar al pago de sumas mayores que las demandadas por el mismo concepto, cuando aparezca que éstas son inferiores a las que corresponden al trabajador, de conformidad con la ley, y siempre que no hayan sido pagadas". COLÔMBIA. Código Procesal del Trabajo y de la Seguridad Social. Decreto-Ley 2158/1948. Disponível em:
} 
sugere a total inaplicabilidade do princípio da congruência ao Processo do Trabalho brasileiro $^{100}$.

Em que pese o latente desejo de insurreição contra a ordem estabelecida, há que se fazer uma ponderação: como se verá adiante, o princípio da congruência tem suporte em diversos outros princípios caros ao processo democrático e que são aplicáveis ao Processo Trabalhista. Além disso, não se pode esquecer que a lei não é a única fonte do Direito, sendo assim também consideradas a doutrina ${ }^{101}$ e a jurisprudência ${ }^{102}$, estas, como já dito, favoráveis à compatibilidade de tal princípio com o Processo Laboral. Desse modo, como se verá adiante, as objeções à aplicação do princípio da congruência ao Processo do Trabalho, apontadas por Christiane Moura Velho serão levadas em conta, mas na condição de flexibilizadoras de tal princípio.

Feita a devida ressalva, devem ser examinados os fundamentos principiológicos do tema ora estudado. José Carlos Barbosa Moreira ${ }^{103}$ identifica dois possíveis fundamentos para essas previsões legais. O primeiro é o princípio dispositivo, que prevê que as partes têm liberdade não apenas para submeter o conflito à jurisdição estatal, mas também para decidir qual porção desse conflito será julgada. Nessa linha de raciocínio, Enrico Tulio Liebman diz que as partes são soberanas ${ }^{104}$. Tal posição está fundamentalmente ligada à concepção liberal do Estado ${ }^{105}$, no sentido de que o processo é "problema das partes". Outro fundamento da correlação entre pedido e sentença - e este é o preferido de Barbosa Moreira - é o respeito ao contraditório, como garantia de previsibilidade do resultado. Nota-se que tal previsibilidade serve às duas partes, pois o réu, ao elaborar sua defesa, pode prever a sua perda e o autor tem a garantia de que o juiz, em caso de improcedência, não negará nada além do pedido.

<http://www.secretariasenado.gov.co/senado/basedoc/codigo/codigo_procedimental_laboral.html>. Acesso em: 17 dez. 2010.

${ }^{100}$ VELHO, Christiane Moura. Da sentença 'extra' e 'ultra petita' e a Justiça do Trabalho. Campinas, 2004. 41 f. Monografia (Especialização em Direito e Processo do Trabalho) - Pontifícia Universidade Católica de Campinas. Orientação do Professor Manoel Carlos Toledo Filho, Campinas, 2004. p. 32.

${ }^{101}$ Ver nota $\mathrm{n}^{\circ} 95$.

102 Tal é a aceitação do princípio da congruência no Processo do Trabalho, que o TST editou a súmula 298, cujo inciso $\mathrm{V}$ dispõe que "não é absoluta a exigência de prequestionamento na ação rescisória. Ainda que a ação rescisória tenha por fundamento violação de dispositivo legal, é prescindível o prequestionamento quando o vício nasce no próprio julgamento, como se dá com a sentença "extra, citra e ultra petita".

${ }^{103}$ BARBOSA MOREIRA, José Carlos. Correlação entre pedido e sentença. Revista de Processo, São Paulo, v. 21, n. 83, p. 207-215, jul./set. 96.

${ }^{104}$ LIEBMAN, Enrico Tulio. O despacho saneador e o julgamento do mérito. Revista dos Tribunais.

105 José Roberto dos Santos Bedaque sustenta que o princípio da congruência é uma opção do legislador e uma escolha ideológica do Estado, que prefere deixar às partes o poder de fixar o objeto da controvérsia. Ver BEDAQUE, José Roberto dos Santos. Poderes instrutórios do juiz. São Paulo: Revista dos Tribunais, 2009. p. 9 e 10 . 
Como já dito, o princípio da congruência não é unanimidade nos ordenamentos processuais modernos, sendo possível identificar no Direito brasileiro, não apenas princípios confirmadores do princípio da congruência, mas também princípios flexibilizatórios, que serão estudados neste momento. Ressalta-se que esta divisão não é estanque, pois alguns dos princípios ora chamados de confirmadores, como o da isonomia das partes, poderão, em determinadas circunstâncias, provocar efeito contrário. Para esta classificação, utilizou-se o critério de atuação do juiz: os princípios que, tradicionalmente, limitam o poder do juiz, foram colocados na primeira categoria, enquanto os que concedem mais liberdade ao julgador foram destinados à segunda categoria.

\subsubsection{Princípios Confirmadores}

\subsubsection{Princípio da Inércia da Jurisdição}

O princípio da inércia da jurisdição é o ponto de partida do processo: dispõe o artigo $2^{\circ}$ do CPC que "nenhum juiz prestará a tutela jurisdicional senão quando a parte ou o interessado a requerer, nos casos e forma legais". Embora não haja na CLT previsão correspondente a esta, pode-se inferir que esse princípio vigora no Processo Trabalhista pela leitura do artigo 839, o qual dispõe que -“a reclamação poderá ser apresentada: a) pelos empregados e empregadores, pessoalmente, ou por seus representantes, e pelos sindicatos de classe; b) por intermédio das Procuradorias Regionais da Justiça do Trabalho". Ou seja, o princípio da inércia da jurisdição deixa a cargo das partes a iniciativa de levar a juízo o seu conflito, apresentando-o do modo que lhes for mais conveniente. Apesar de contar com algumas exceções, entre as quais interessa o já citado artigo 39 da CLT - que prevê o envio de procedimento administrativo relativo à anotação em Carteira de Trabalho e Previdência Social (CTPS) à Justiça do Trabalho -, não há polêmica relevante sobre a aplicação deste princípio ao Processo do Trabalho.

A ligação do princípio da inércia da jurisdição com o princípio da congruência é patente: a ausência de iniciativa da parte na instauração de um processo leva à óbvia inexistência de um pedido, e não é lícito ao juiz proferir sentença sobre pedido inexistente. Ora, mas não é possível o processo existir e inexistir o pedido sobre o qual decide a sentença? Esta é a definição clássica de violação ao princípio da congruência, especificamente de sentença extra petita! Isso significa que, a princípio, a relativização da 
regra da congruência iria fatalmente de encontro com o princípio da inércia da jurisdição. Contudo, há que se lembrar que a petição é muito mais que apenas o pedido e que, se por um lado o juiz é inerte quanto à iniciativa processual, por outro cabe a ele dar o devido impulso para que o processo seja resolvido, sendo obrigado a conhecer de determinadas matérias de ofício, como as de ordem pública.

\subsubsection{Princípio Dispositivo}

Tradicionalmente, o princípio dispositivo é visto como outra faceta do princípio da inércia da jurisdição, referindo-se, portanto a questões como a propositura da ação e a delimitação do objeto do processo. Nesse sentido, José Manuel de Arruda Alvim sustenta que o princípio ora estudado é antagônico aos princípios da indisponibilidade e da oficialidade e se caracteriza pelos seguintes aspectos: (i) o autor tem direito a fixar os fatos dos quais pretende extrair consequências jurídicas; (ii) o autor pode deixar de apresentar alguns fatos, que o juiz não poderá conhecer de ofício; (iii) ao autor cabe escolher as consequências jurídicas de seus fatos, não podendo o juiz conceder outra, mesmo que mais vantajosa $^{106}$. Nota-se que tal concepção relaciona o princípio dispositivo diretamente com os atos processuais, ou seja, com a possibilidade de atuação do juiz no processo, sem se ater, necessariamente, ao direito material discutido.

Correntes mais modernas pretendem corrigir o uso que se dá ao princípio dispositivo, por vezes confundido com o da inércia da jurisdição ou o da autonomia da vontade, limitando seu sentido

aos reflexos que a relação de direito material disponível possa produzir no
processo. E tais reflexos referem-se apenas à própria relação jurídico-substancial.
Assim, tratando-se de direito disponível, as partes têm ampla liberdade para dele
dispor, através de atos processuais (renúncia, desistência, reconhecimento do
pedido). (...) Trata-se de um princípio relativo à relação material, não à
processual ${ }^{107}$.

Esse segundo entendimento, ao contrário do anterior, dá outra dimensão ao princípio da congruência, que passa a ser vigente ou não de acordo com o direito material discutido. Para Vallisney de Souza Oliveira, "a incidência do princípio dispositivo se refere à atuação dos litigantes no processo, exclusivamente em razão da disposição advinda do

\footnotetext{
106 ARRUDA ALVIM, José Manuel de. Dogmática jurídica e o novo código de processo civil. Revista de Processo, São Paulo, v. 1, n. 1, p. 85-133, jan./mar. 76. p. 95-96.

${ }^{107}$ BEDAQUE, José Roberto dos Santos. Poderes instrutórios do juiz, p. 91.
} 
direito material" ${ }^{\text {108 }}$, de modo que apenas quando se tratar de direito material disponível o juiz deverá ficar adstrito à vontade das partes, podendo superá-la caso a matéria discutida seja de ordem pública, situação em que o juiz é obrigado a julgar de acordo com as previsões legais expressas, não podendo derrogá-las em razão da vontade das partes.

Ora, a indisponibilidade é a principal característica do Direito Material Laboral, como já foi visto no item 2.4.3, de forma que o princípio dispositivo, no Direito Processual do Trabalho, só age como confirmador do princípio da congruência nas hipóteses em que o direito discutido for disponível, o que configura exceção nessa área.

\subsubsection{Princípio do Contraditório}

Conhecido como a democracia no processo, o princípio do contraditório é elemento essencial do processo moderno, garantido pelo artigo $5^{\circ}, \mathrm{LV}$, da CF. Fredie Didier Jr. o divide em duas facetas: a formal, que é a garantia de ser ouvido, de participar do processo, de ser comunicado dos atos processuais; e a substancial, que a este trabalho interessa mais de perto e consiste na possibilidade de influenciar o julgamento do juiz, interferindo em sua decisão ${ }^{109}$, não apenas pela argumentação, mas também - e principalmente - pela produção de provas.

Tal noção está intimamente ligada ao binômio clássico do contraditório informação-reação - e dela se depreende imediatamente o fundamento do princípio da congruência: sendo garantido às partes o conhecimento total e prévio de todos os elementos do processo, bem como a possibilidade de se manifestar sobre eles, não se poderia conceber em um sistema processual que garantisse o contraditório o proferimento de uma sentença que versasse sobre pedido não expresso nos autos, pois seria de se supor que sobre ele as partes não teriam tido a oportunidade de se defender. Nas palavras de José Cretella Neto, "se assim não fosse, às partes restaria manter-se em estado de permanente insegurança e sobressalto, durante o curso do processo, na medida em que poderia ser surpreendidas com decisões estranhas à lide, ao final do litígio" ${ }^{110}$. Neste sentido, o contraditório é entendido como limitação ao poder do magistrado.

\footnotetext{
${ }^{108}$ OLIVEIRA, Vallisney de Souza. Nulidade da sentença e o princípio da congruência. São Paulo: Saraiva, 2004. p. 74.

${ }^{109}$ DIDIER JUNIOR, Fredie. Curso de direito processual civil. Salvador: JusPodivm, 2008. p. 45.

110 CRETELLA NETO, José. Fundamentos principiológicos do processo civil. Rio de Janeiro: Forense, 2002. p. 155.
} 
Contudo, a concepção moderna de contraditório deve acompanhar a figura do juiz participativo. Para esta corrente, contraditório não é simplesmente o diálogo entre as partes, mas também o diálogo com o juiz, com vistas a um processo efetivo, equitativo e justo. Nesse sentido, uma sentença que leva em consideração fatos não alegados na inicial, mas provados e discutidos durante o processo não pode ser considerada alheia ao princípio do contraditório. Tal possibilidade, aliás, vem expressamente prevista nos artigos 131 - "O juiz apreciará livremente a prova, atendendo aos fatos e circunstâncias constantes dos autos, ainda que não alegados pelas partes; mas deverá indicar, na sentença, os motivos que lhe formaram o convencimento" - e 462 - "Se, depois da propositura da ação, algum fato constitutivo, modificativo ou extintivo do direito influir no julgamento da lide, caberá ao juiz tomá-lo em consideração, de ofício ou a requerimento da parte, no momento de proferir a sentença" -, ambos do CPC.

Tem-se, portanto, que a chave de ouro do contraditório é o constante diálogo e a possibilidade de manifestação sobre todos os aspectos do processo, sejam eles apresentados pelas partes, sejam conhecidos de ofício pelo juiz, de modo que eventual afastamento do princípio da congruência pode ser compatível com o processo democrático, mantendo-se intacto o previsto no artigo $5^{\circ}, \mathrm{LV}$, da CF.

\subsubsection{Princípio da Isonomia e Princípio da Imparcialidade do Juiz}

Optou-se por tratar dos dois princípios juntamente em razão da inequívoca relação de causalidade entre eles: o juiz, sendo o condutor do processo e em virtude de sua imparcialidade, mantém a igualdade entre as partes.

O princípio da isonomia no processo decorre da regra constitucional mais citada, prevista no caput do artigo $5^{\circ}$, que diz que todos são iguais perante a lei, de modo que é imprescindível que o juiz, na sua atuação, não crie distinções entre os atores do processo, permitindo que todos possam atuar judicialmente com as mesmas oportunidades. Assim, não pode o juiz, por motivos alheios à lei e aos autos, manejar o processo dando preferência a uma das partes, mesmo que seus sentimentos morais mais íntimos assim lhe aconselhem.

O princípio da congruência encontra nas regras da isonomia e da imparcialidade a garantia de que o juiz não atuará em favor de nenhuma das partes, o que implica não acolher pedido não formulado - caso contrário estaria atuando como advogado da parte e não como magistrado - e garantir a igual oportunidade de manifestação nos autos, uma vez 
que o julgamento fora dos limites da lide, em princípio, implica a concessão de tutela sobre matéria não discutida.

Porém, é pacífico na doutrina brasileira que não basta a garantia da igualdade formal no processo, sendo necessário observar a igualdade substancial entre as partes para garantir o efetivo acesso à justiça. No Processo Comum, exemplo clássico da calibração da atuação das partes é o artigo 6º VIII, da Lei n 8.078 de 11 de setembro de 1990 (Código de Defesa do Consumidor), que prevê a possibilidade de inversão do ônus da prova em ações judiciais consumeristas, em razão da evidente posição desfavorável do consumidor frente às empresas. No Processo do Trabalho, como visto no item 2.4.1, também se reconhece a disparidade entre empregado e empregador, prevendo a lei processual situações idênticas que acarretam consequências diferentes para as partes, como é a ausência na audiência una, que gera o arquivamento da ação, caso ausente o reclamante, ou a revelia, caso ausente a reclamada. Importante consideração a ser feita é que a lei processual trabalhista não permite ao juiz ser imparcial: pelo contrário, prevê as hipóteses, devidamente fundamentadas no Direito Material, em que o magistrado pode dispensar o tratamento idêntico às partes: a distinção, portanto, é feita pela lei e não pelo juiz! É crucial que se abandone o preconceito de que a Justiça do Trabalho é parcial, injustificavelmente favorável ao empregado ${ }^{111}$, para que se possa reconhecer a legitimidade técnica de suas decisões.

Não se pode, contudo, supor que os juízes realmente conduzam um processo sem fazer qualquer tipo de consideração "não jurídica" sobre a matéria discutida: conforme Rui Portanova,

os juízes são profundamente afetados por sua concepção de mundo: formação
familiar, educação autoritária ou liberal, valores de sua classe social, aspirações e
tendências ideológicas de sua profissão (...) e, assim, também o juiz é levado a
dar significado e alcance universal e até transcendente àquela ordem de valores
imprimida em sua consciência individual (...) depois vê tais valores nas regras
jurídicas (...) é a motivação ideológica da sentença ${ }^{112}$.

Logo, um juiz que seja sensível aos princípios democráticos e de igualdade material, atuará de modo a garantir formal e materialmente o acesso ao Judiciário. Deste modo, não se pode ser ingênuo a ponto de acreditar que as decisões judiciais são neutras:

\footnotetext{
111 Caso exemplar de conduta "antiobreira" foi o adiamento de audiência una em razão dos trajes do Reclamante. Conforme consta em ata, o "Juízo deixa registrado que não irá realizar esta audiência, tendo em vista que o reclamante compareceu em Juízo trajando chinelo de dedos, calçado incompatível com a dignidade do Poder Judiciário". Processo nº 01468-2007-195-09-00-2, tramitou perante a $3^{\text {a }}$ Vara Trabalhista de Cascavel, Paraná. Disponível em: <http://www.trt9.jus.br/internet_base/publicacaoman.do?evento= Editar\&chPlc=2516243\&procR=AAAbqKAAaAAKhf9AAY\&ctl=1468>. Acesso em: 17 dez. 2010.

${ }^{112}$ PORTANOVA, Rui. Motivações ideológicas da sentença. Porto Alegre: Livraria do Advogado, 1994. p. 16.
} 
são carregadas não apenas da concepção de mundo dos juízes, mas principalmente da carga valorativa do Direito Material, que não é imparcial.

Diante da peculiaridade da relação trabalhista no tocante à isonomia, o princípio da congruência tem seu papel diminuído, havendo que se permitir certa elasticidade na interpretação da causa de pedir e do pedido na reclamação trabalhista, sob pena de não fazer atuar completamente a norma trabalhista.

Antes de terminar este subitem, ainda cabem mais algumas observações sobre o princípio da isonomia, para além da relação de hipossuficiência existente no campo laboral. Usualmente, diz-se que às partes deve ser garantida a paridade de armas e que $o$ processo é uma luta ${ }^{113}$. Embora esta seja uma noção amplamente difundida, há que se notar que não condiz com a ideia fundamental de que o processo destina-se à pacificação social e ao efetivo cumprimento da lei.

Existe uma cultura arraigada no modo como se trata o processo no Brasil que é a de combate, de estar em um campo de batalha, esperando que o adversário dê um passo em falso e que, com isso, se ganhe a guerra. Esta concepção traz duas consequências funestas. A primeira é a postura belicosa que se vê no dia a dia forense, não apenas entre as partes, mas entre advogados e até mesmo entre advogados e juízes; a segunda é a resistência de reconhecimento do direito do outro: considera-se "natural" apresentar contestações, recursos e todos os tipos possíveis de impugnação à execução, objeções nem sempre motivadas por razões pecuniárias, mas, por vezes, por um sentimento profundo de superioridade à lei e às decisões judiciais. Para tanto, os mecanismos processuais são utilizados como meios de obtenção de resultados mesquinhos e injustos. Decerto, tal conduta no processo é sintomática de uma questão maior, que se deixa à Sociologia discutir, mas que não deve ser transposta com tamanha simplicidade ao processo: se o seu objetivo é o efetivo cumprimento da lei, não há melhor arma para as partes do que a titularidade do direito, de modo que se deve evitar ao máximo que tal objetivo não seja atingido por questões meramente processuais.

\subsubsection{Princípio da Preclusão}

Com o intuito de evitar idas e vindas no processo, garantindo a celeridade processual, o legislador criou o instituto da preclusão, que nada mais é do que impossibilidade da prática de um ato processual por perda do momento temporal, por

\footnotetext{
${ }^{113}$ DIDIER JUNIOR, Fredie. Curso de direito processual civil, p. 44.
} 
ausência de conveniência lógica ou por já ter havido a prática válida desse mesmo ato. Tem previsão expressa no artigo 473 do CPC - "É defeso à parte discutir, no curso do processo, as questões já decididas, a cujo respeito se operou a preclusão" - e nos artigos 795, caput - “As nulidades não serão declaradas senão mediante provocação das partes, as quais deverão argüi-las à primeira vez em que tiverem de falar em audiência ou nos autos" - e 879, $\S 2^{\circ}$ e $\S 3^{\circ}$, ambos da CLT:

\begin{abstract}
Sendo ilíquida a sentença exeqüenda, ordenar-se-á, previamente, a sua liquidação, que poderá ser feita por cálculo, por arbitramento ou por artigos. (...) $\S 2^{\circ}$ Elaborada a conta e tornada líquida, o Juiz poderá abrir às partes prazo sucessivo de 10 (dez) dias para impugnação fundamentada com a indicação dos itens e valores objeto da discordância, sob pena de preclusão.

$\$ 3^{\circ}$ Elaborada a conta pela parte ou pelos órgãos auxiliares da Justiça do Trabalho, o juiz procederá à intimação da União para manifestação, no prazo de 10 (dez) dias, sob pena de preclusão.
\end{abstract}

A preclusão tem ligação direta com a estabilização da demanda, que ocorre após o saneamento do processo e é o momento a partir do qual não é admitida, em tese, nenhuma modificação nos pedidos e nas alegações das partes. Tal é a redação do artigo 264 do CPC - "Feita a citação, é defeso ao autor modificar o pedido ou a causa de pedir, sem o consentimento do réu, mantendo-se as mesmas partes, salvo as substituições permitidas por lei”. Pois bem. Tal artigo sustenta o princípio da congruência na medida em que a flexibilização dessa regra implicaria a inserção de novos elementos no processo, fora do momento oportuno, criando incidentes infinitos no processo.

Não obstante, há que se notar que a preclusão é regra destinada às partes e não ao juiz, que tem ampla liberdade para a direção do processo e pode, no âmbito laboral, determinar qualquer diligência necessária ao bom andamento do mesmo (artigo 765 da CLT), de modo que, se julgar conveniente, pode dar alguns passos para trás ${ }^{114}$. Assim, não haveria violação ao princípio da preclusão caso o magistrado, entendendo pertinente a discussão de fato não aventado na inicial ou na contestação, abra prazo para que as partes sobre ele se manifestem, para posteriormente proferir sentença, abrangendo-o. Garantindose sempre o contraditório, não há que se falar em nulidade.

\footnotetext{
${ }^{114}$ Para José Roberto dos Santos Bedaque, "a preclusão é simples mecanismo técnico destinado a permitir o normal desenvolvimento da relação processual. Deve ceder diante de valor maior, como o representado pelo convencimento do juiz a respeito da realidade jurídico-material". Ver BEDAQUE, José Roberto dos Santos. Poderes instrutórios do juiz, p. 21 e 22.
} 


\subsubsection{Princípios Flexibilizatórios}

\subsubsection{Princípio do Iura Novit Curia e do Da Mihi Factum, Dabo Tibi Ius}

Brocardos clássicos do Direito Processual, iura novit curia costuma ser traduzido como o juiz conhece o direito, ao passo que da mihi factum, dabo tibi ius significa dá-me os fatos que te darei o direito. Em suma, ambos referem-se não apenas à presunção de que o juiz conhece as normas jurídicas, mas também ao fato de que é obrigado a conhecê-las, não ficando vinculado aos fundamentos jurídicos apontados pelas partes.

Ao contrário do que sustenta Vallisney de Souza Oliveira ${ }^{115}$, não se pode fundamentar tais princípios no artigo $3^{\circ}$ do Decreto-Lei $n^{\circ} 4.657$ de 4 de setembro de 1942 (Lei de Introdução ao Código Civil), muito menos na crença de que o magistrado tem conhecimento da lei por ser bacharel em Direito e ter sido aprovado em concurso público: o juiz conhece o Direito porque recebe parcela da jurisdição estatal (competência) para a aplicação da lei. O juiz é a personificação do Estado ${ }^{116}$, justamente o Estado que emite as leis, não se podendo supor que quem as cria as não as conheça. Tanto é assim que o artigo 337 do CPC dispensa a produção de prova sobre norma de âmbito federal, condicionando a prova do teor e vigência de direito municipal, estadual, estrangeiro ou consuetudinário se assim determinar o juiz. Ou seja, a comprovação prevista no referido artigo destina-se ao magistrado: caso ele tenha conhecimento prévio de tal norma, pode dispensar a prova.

Por este ângulo os princípios ora estudados podem ser compreendidos não simplesmente como dispensa da demonstração do direito aplicável ao caso na hipótese de propositura de ação ou de defesa, mas sim como uma obrigação do juiz de aplicar corretamente o Direito ao caso concreto, em um verdadeiro ato de subsunção fato-norma, fazendo valer, em última instância, a vontade do próprio Estado que emitiu a referida norma. A polêmica, contudo, não se refere exatamente à possibilidade ou não de o juiz dar fundamento jurídico diverso à pretensão da parte, mas sim às consequências jurídicas deste reenquadramento.

Nesse sentido, duas situações podem ser imaginadas: (i) o novo enquadramento jurídico dos fatos tem consequências jurídicas idênticas às pretendidas pela parte; ou (ii) o novo enquadramento jurídico leva a consequências diferentes das pleiteadas pela parte. A

\footnotetext{
${ }^{115}$ OLIVEIRA, Vallisney de Souza. Nulidade da sentença e o princípio da congruência, p. 101.

${ }^{116}$ Para Fredie Didier Junior, “a jurisdição é uma, porquanto manifestação do poder estatal". Ver DIDIER JUNIOR, Fredie. Curso de direito processual civil, p. 101.
} 
primeira não traz nenhuma implicação relevante para o estudo do princípio da congruência, uma vez que nessa situação restam respeitados os limites da pretensão da parte, mesmo que reconhecida sob fundamento jurídico diverso do apontado ${ }^{117}$. Já a segunda pode levar a sentença ultra ou extra petita. Vallisney de Souza Oliveira sugere que, neste caso, o juiz deve optar pela improcedência do pedido ${ }^{118}$. Em homenagem ao princípio da economia processual, a ser analisado mais a frente, sugere-se, desde já, que, em vez de extinguir o processo, o juiz abra prazo para que o autor se manifeste sobre a intenção de dar continuidade ao processo diante do novo cenário, abrindo-se igual oportunidade para eventual defesa.

Contudo, e se se estiver diante de um novo enquadramento legal baseado em norma de ordem pública? É sabido que tais normas atuam independentemente da vontade das partes, de modo que a solução anteriormente sugerida não se poderia aplicar nesse caso, sob pena de desvirtuar a natureza pública de uma disposição normativa, tornando disponíveis direitos indisponíveis. Tal seria o caso de trabalhador que propusesse reclamação pleiteando o pagamento de retribuição pecuniária em atraso e o juiz, pela descrição dos fatos e provas produzidas, entendesse que a pretensão não se fundamenta no contrato de prestação de serviços do Código Civil, mas sim no contrato de emprego da CLT. Pois bem. A norma que prevê o vínculo empregatício tem natureza de ordem pública e o reconhecimento de tal liame gera consequências que ultrapassam os interesses das partes, como fiscais e previdenciárias. O magistrado, percebendo que o conflito que foi levado a juízo deve ser resolvido pela aplicação da norma trabalhista, pode simplesmente deixar de julgar, assim premiando a conduta fraudulenta de uma das partes ou, por vezes, de ambas? Decerto que não, pois estaria violando o princípio da indeclinabilidade do julgamento, a ser estudado mais adiante. Neste caso, nem poderia o magistrado perguntar às partes se lhes convêm as novas consequências, devendo abrir prazo para manifestações.

Decerto, o entendimento ora esposado pode soar como rechaço do princípio da congruência, mas não se pode esquecer que ao juiz é defeso conhecer apenas de questões não suscitadas que dependam de iniciativa da parte (artigo 128 do CPC). Não sendo este o caso das normas de ordem pública, estaria o juiz legalmente autorizado a proferir sentença ultra ou extra petita, na hipótese descrita no parágrafo anterior.

\footnotetext{
117 A vinculação ou não do juiz aos fundamentos jurídicos apontados pelas partes será objeto de argumentação mais aprofundada no item que tratará da petição inicial e seus requisitos.

${ }^{118}$ OLIVEIRA, Vallisney de Souza. Nulidade da sentença e o princípio da congruência, p. 102.
} 


\subsubsection{Princípio do Indeclinabilidade do Julgamento}

Apesar de já ter sido abordado no subitem anterior, o princípio da indeclinabilidade do julgamento merece atenção especial. Trata-se da proibição dirigida ao juiz de que se exima da apreciação das questões fáticas e jurídicas que lhe são trazidas pelas partes. Mais uma vez, há que se olhar além: o princípio ora estudado, previsto constitucionalmente no artigo $5^{\circ}, \mathrm{XXXV}$, é direito fundamental que garante uma resposta a todos os cidadãos que buscam o Judiciário, ou seja, é uma garantia da onipresença do Estado. A ausência de resposta estatal, inclusive, pode ser objeto de apreciação pela Comissão Interamericana de Direitos Humanos, como ocorreu no célebre caso de Maria da Penha, que esperou mais de 15 anos para ouvir um pronunciamento judicial ${ }^{119}$. Trata-se, portanto, de princípio que visa garantir o acesso à justiça.

De início, sua relação com o princípio da congruência revela-se pela coadunação com a proibição do julgamento citra petita: neste caso, deveria ser entendido como um confirmador do princípio da congruência. Porém, se se considerar que o objetivo do processo é a resolução de um conflito e a pacificação social, a indeclinabilidade de julgamento assume outra dimensão, pois é certo que, em algumas circunstâncias, a narrativa da inicial e a da contestação, a produção de provas e até mesmo a postura das partes pode revelar que a solução jurídica proposta por elas não satisfará todos os problemas levados a juízo, de forma que, ao ignorar tais questões, não estaria o magistrado deixando de cumprir sua função? Decerto, há que se ponderar essa argumentação com o princípio dispositivo, já que é possível que, no caso de direitos disponíveis, as partes tenham escolhido deixar alguns fatos de fora.

Mas e se se tratar de direitos indisponíveis, cuja aplicação independe da vontade da parte? Mais uma vez, volta-se à questão do vínculo empregatício: o artigo 626 da CLT e o artigo $7^{\circ}, \S 1^{\circ}$, da lei 7.855 de 24 de outubro de 1989 garantem ao Auditor Fiscal do Trabalho a atribuição de reconhecer vínculo empregatício, quando do desempenho de suas funções, sem que tenha, por óbvio, que perguntar aos trabalhadores se desejam tal reconhecimento. Supor que tal prerrogativa seja negada ao magistrado implicaria a inutilidade do Judiciário, de forma que se teria que manter um fiscal do trabalho em cada sala de audiência para garantir a efetividade da norma trabalhista. Exageros à parte, há que

119 COMISSÃO INTERAMERICANA DE DIREITOS HUMANOS. Relatório Anual 200. Relatório $\mathrm{n}^{\mathbf{0}}$ 54/01, Caso 12.051, Maria da Penha Maia Fernandes. Disponível em: <http://www.cidh.org/annualrep/ 2000port/12051.htm>. Acesso em: 17 dez. 2010. 
se reconhecer que a salvaguarda do princípio dispositivo não pode levar à negação - ainda que por omissão - de direitos indisponíveis, e que o juiz está obrigado, pelo princípio da indeclinabilidade do julgamento, a apreciar todas as questões que surgem no processo, podendo conhecer de ofício as relativas a normas de ordem pública e a direitos indisponíveis, não sendo nula a sentença que nestes termos decidir.

\subsubsection{Princípio da Economia Processual}

A atividade jurisdicional, assim como qualquer outra atividade estatal, implica custos, destinados a financiar todo o aparato do Judiciário: a título de exemplo, no ano de 2008, o Tribunal Regional do Trabalho da $2^{\text {a }}$ Região acumulou um total de despesas de $\mathrm{R} \$ 1.107 .997 .202,72$ (um bilhão, cento e sete milhões, novecentos e noventa e sete mil, duzentos e dois reais e setenta e dois centavos), sendo que arrecadou apenas de $\mathrm{R} \$$ 47.467.168,28 (quarenta e sete milhões, quatrocentos e sessenta e sete mil, cento e sessenta e oito reais e vinte e oito centavos) em custas processuais ${ }^{120}$, valores destinados à sua manutenção. Tem-se que, ao contrário do se pensa, a justiça não é de graça e acarreta altos custos para toda a sociedade; além disso, deve-se atentar para o fato de que seus gastos são diretamente proporcionais à quantidade de processos que tramitam no Judiciário.

Nesse sentido, o princípio da economia processual age de modo a evitar, pela técnica processual, que se proliferem as ações judiciais. O mecanismo mais efetivo para alcançar tal objetivo é, sem dúvida, a ação coletiva. No plano individual, objeto de análise desta dissertação, a economia processual é homenageada pelo aproveitamento dos atos processuais, de acordo com a teoria da instrumentalidade do processo, da qual tratou o capítulo anterior: assim, o juiz deve evitar ao máximo, sempre respeitando o devido processo legal, emitir decisões terminativas sem análise do mérito, e deve também ser receptivo à formação de litisconsórcios ativos e ao recebimento de reconvenções, pois estas são maneiras de se discutir em apenas um processo questões que poderiam ser objeto de ações autônomas.

Porém, o princípio da economia processual não se limita à redução de custos; destina-se, principalmente, à resolução do conflito de um modo satisfatório, pela efetividade do processo. Nesse sentido também o juiz deve flexibilizar a forma em favor da

\footnotetext{
120 Relatório do Conselho Nacional de Justiça do Programa Justiça em Números. Disponível em: <http://www.cnj.jus.br/images/conteudo2008/pesquisas_judiciarias/trt02.pdf>. Acesso em: 21 dez. 2010.
} 
substância, dirigindo sua atividade para o proferimento de uma decisão de mérito, pois isso é efetivo acesso à justiça, é dar às partes uma decisão substancial sobre o direito discutido. Assim defende José Roberto dos Santos Bedaque:

como a forma não constitui valor em si mesma, o formalismo processual deve
ser examinado à luz dos objetivos a serem alcançados. Assegurada a participação
dos interessados na formaçãa do convencimento do julgador - e, portanto, no
resultado do processo -, o problema da forma acaba passando para segundo
plano $^{121}$.

A regra de ouro para a economia processual é evitar o acolhimento de preliminares de mérito ou a decretação de nulidades quando não houver prejuízo à parte interessada, com vistas à apreciação do mérito do processo.

A flexibilização do princípio da congruência é cara à economia processual, pois permite a resolução mais completa possível do conflito, dando à parte o que lhe é de direito e evitando a propositura de novas ações. Imagine-se, por exemplo, uma reclamação trabalhista em que o autor pleiteia o pagamento de férias. A rigor, o princípio da congruência obrigaria o juiz a lhe dar apenas o valor das férias, sem o acréscimo de um terço, previsto no artigo $6^{\circ}$, XVII, da CF, o que obrigaria o autor a ingressar com nova ação após a prolação da sentença. A possibilidade de afastar o princípio da congruência em algumas situações permitiria ao julgador conceder-lhe as férias acrescidas do terço, evitando a propositura de nova reclamação e garantindo a tutela efetiva de seu direito.

\subsubsection{Princípio do Livre Convencimento do Juiz}

O artigo 35, I, da Lei Complementar no 35 de 14 de março de 1979 diz que é dever do juiz "cumprir e fazer cumprir, com independência, serenidade e exatidão, as disposições legais e os atos de ofício", sendo que o CPC utiliza expressamente o termo "livre", referindo-se à atividade jurisdicional, em $5 \operatorname{artigos}^{122}$, destacando-se o disposto no artigo 131 - “O juiz apreciará livremente a prova, atendendo aos fatos e circunstâncias constantes dos autos, ainda que não alegados pelas partes; mas deverá indicar, na sentença, os motivos que lhe formaram o convencimento". Como se vê, a liberdade do juiz é requisito essencial do processo moderno, pois não se pode admitir que o magistrado seja submetido a interesses estranhos à vontade da lei, seja pela coação, seja pela corrupção passiva.

\footnotetext{
${ }^{121}$ BEDAQUE, José Roberto dos Santos. Efetividade do Processo e Técnica Processual. São Paulo: Malheiros, 2007. p. 46.

${ }^{122}$ Artigos $131,353,386,439$ e 1.1 .07 do CPC.
} 
Embora o artigo 131 fale especificamente de livre apreciação das provas, tal dispositivo normativo pode ser entendido como uma verdadeira garantia ao juiz de que poderá considerar os fatos narrados e provados nos autos e, a partir daí, formular seu convencimento e proferir a sentença ${ }^{123}$ : ou seja, para decidir o juiz não observará somente o pedido das partes ou as relações lógicas por elas estabelecidas, podendo, por si só, no âmbito da matéria discutida, alcançar a pretensão das partes por vias diversas das sugeridas. A contrapartida dessa liberdade é a obrigação da fundamentação das decisões, prevista no referido artigo e no artigo 93, IX, da CF:

Todos os julgamentos dos órgãos do Poder Judiciário serão públicos, e fundamentadas todas as decisões, sob pena de nulidade, podendo a lei limitar a presença, em determinados atos, às próprias partes e a seus advogados, ou somente a estes, em casos nos quais a preservação do direito à intimidade do interessado no sigilo não prejudique o interesse público à informação.

Não há dúvida de que o artigo supracitado é essencial para a preservação do contraditório, pois permite que o jurisdicionado conheça exatamente os fundamentos utilizados na decisão, podendo examinar se há motivos adotados sobre os quais não tenha havido oportunidade de se manifestar. Resta a pergunta: se é lícita a decisão que se fundamenta em fatos ou circunstâncias não alegados pelas partes, mas provados, por que não se pode admitir uma decisão que, com base nesses mesmos fatos e circunstâncias, conceda à parte algo diverso ou superior do pleiteado, se assim determinar a lei, e se tratando de um direito indisponível? Volte-se ao exemplo do terço de férias: o trabalhador pleiteia o pagamento de férias, prova por testemunha que jamais gozou do descanso, junta holerites de que não consta o lançamento do pagamento devido, e o empregador não leva aos autos recibo de gozo e pagamento de férias, alegando apenas que cumpriu com seus deveres legais. Não é razoável uma sentença que conclua pelo pagamento do terço constitucional ${ }^{124}$ ? Ora,

\footnotetext{
${ }^{123}$ Nas palavras de Antônio Cláudio da Costa Machado, tal artigo é a consagração do princípio do livre convencimento. Ver MACHADO, Antônio Cláudio da Costa. Código de processo civil interpretado e anotado. São Paulo: Manole, 2008. p. 410.

124 “AGRAVO DE INSTRUMENTO. HORAS EXTRAS. REFLEXOS SOBRE FÉRIAS E FGTS. AUSÊNCIA DE PEDIDO QUANTO AO TERÇO CONSTITUCIONAL E À MULTA DE $40 \%$. ACESSORIEDADE. AUSÊNCIA DE JULGAMENTO EXTRA PETITA. Não há dúvida, até em virtude do entendimento sedimentado no Enunciado 328 do TST, de que o acréscimo da terça parte não é um adicional ou plus proporcional a ser adicionado ao valor das férias. O inciso XVII do artigo $7^{\circ}$ da Constituição Federal claramente estatui que a remuneração das férias corresponde a um salário normal mais um terço desse salário. Referir-se a férias com $1 / 3$ não passa, portanto, de redundância ainda praticada por força do hábito criado com a inovação, pois o valor normal das férias já compreende o acréscimo da terça parte, como constitucionalmente estabelecido. Quanto à multa de 40\%, idêntica é a linha de raciocínio e fundamentação, por se tratar de típica indenização compensatória da relação de emprego contra a despedida arbitrária ou sem justa causa, estipulada no inciso I do artigo 10 do Ato das
} 
em um processo autônomo sobre o adicional haveria discussão idêntica e a mesma produção de provas!

Ressalta-se, ainda, que, no Processo do Trabalho, em virtude da busca da verdade real, o livre convencimento do juiz ganha mais relevância, não podendo o magistrado fechar os olhos para o que eventualmente for comprovado, sob pena de deixar de aplicar norma cogente.

Tem-se, portanto, que o livre convencimento do juiz pode agir como um flexibilizador do princípio da congruência, desde que atendidos os requisitos do contraditório e da fundamentação das decisões judiciais.

\subsubsection{Princípio do Impulso Oficial}

Se a iniciativa processual civil e trabalhista cabe exclusivamente ao autor (com as já explicitadas exceções), não se pode dizer o mesmo do andamento do processo, que deve ser garantido pela atividade jurisdicional. Tal é o disposto nos artigos 262 do CPC - "O processo civil começa por iniciativa da parte, mas se desenvolve por impulso oficial" - e 765 da CLT - "Os Juízos e Tribunais do Trabalho terão ampla liberdade na direção do processo e velarão pelo andamento rápido das causas, podendo determinar qualquer diligência necessária ao esclarecimento delas". Não se pode chegar ao cúmulo de comparar o processo às palavras que, como no ditado popular, são como flechas, uma vez lançadas, não há como se voltar atrás, já que ao autor é lícito, até determinado momento, desistir da ação. Porém, uma vez esgotado o prazo de resposta do réu, o autor precisa de seu consentimento para desistir da ação ${ }^{125}$. Trata-se de afirmação da seriedade da atividade judicial, alertando o autor de que ele não é "dono" do processo e que, sendo proposta a ação, ela tem um curso ideal a seguir, até a sentença de mérito, resultado que deve ser buscado pelo juiz.

O princípio do impulso oficial é característico do processo inquisitivo e liga-se ao princípio da congruência na medida em que revela uma atividade jurisdicional que independe da vontade das partes. Como se verá adiante, embora a congruência seja vista

Disposições Constitucionais Transitórias e expressamente posta como proteção provisória (até que seja promulgada a lei complementar referida no artigo $7^{\circ}$, inciso I, da Constituição Federal) na forma de acessório do FGTS, cuja respectiva legislação se reveste da natureza jurídica de ordem pública. Assim, os reflexos das horas extras no terço das férias e na multa de $40 \%$ do FGTS são meros acessórios e, nessa condição, prescindem de pedido discriminado na petição inicial, não se cogitando de julgamento extra petita ou ofensa aos artigos $2^{\circ}, 128$ e 460 do CPC". TST, AIRR-50303/2002-900-04-00.5, $3^{\text {a }}$ Turma, Ministra Relatora Wilma Nogueira de A. Vaz da Silva, 26/11/2003.

${ }^{125}$ Artigo 267, $\S 4^{\circ}$, do CPC. 
como requisito da sentença, não fica a isto limitada, estendendo-se, em tese, às decisões interlocutórias do juiz. Nestes casos em especial, é que o impulso oficial flexibiliza o princípio da congruência, permitindo que o juiz dirija o processo de acordo com a melhor técnica, sem ficar adstrito aos pleitos das partes, como ocorre no caso de produção de provas determinada de ofício ${ }^{126}$.

Como se nota, os princípios que regem o Direito Processual brasileiro ora podem ser vistos como confirmadores ora como relativizadores da congruência e tal classificação está mais relacionada com a concepção que se tem do papel do juiz do que com uma qualidade intrínseca dos princípios ${ }^{127}$; assim, optou-se por não inserir o princípio do devido processo legal em nenhuma das categorias, pois se trata de qualidade sine qua non da validade do processo e eventual proposta de relativização do princípio da congruência não pode violar tal garantia, devendo-se buscar mecanismos que permitam que uma sentença ordinariamente considerada incongruente, obedeça aos requisitos de um processo democrático e participativo.

Seja confirmado pela autonomia da vontade das partes, seja flexibilizado pelo iura novit curia, o princípio da congruência é, hoje, uma das principais limitações ao poder jurisdicional e encontra poucos adversários declarados. Contudo, a doutrina e a jurisprudência aceitam algumas exceções que, neste trabalho, serão analisadas a fim de se determinar se de fato constituem situações especiais ou se a sua justificativa poderia ser estendida para outros casos, o que, levado ao extremo, significaria uma subversão do princípio aqui estudado.

\subsection{Petição Inicial e Respostas do Réu: seus Papéis na Delimitação da Lide}

No Capítulo 2, discorreu-se sobre o papel do pedido na delimitação da lide, expondo-se a opinião doutrinária tradicional que entende ser este o requisito da petição inicial que define os parâmetros da sentença. Neste item, buscar-se-á aprofundar essa

\footnotetext{
${ }^{126}$ Artigo 130 do CPC.

127 Vallisney de Souza Oliveira volta-se predominantemente para o caráter limitador dos princípios processuais, para a preservação da congruência. Ver OLIVEIRA, Vallisney de Souza. Nulidade da sentença e o princípio da congruência.
} 
questão pelo estudo de todos os requisitos da petição inicial, com especial atenção para a causa de pedir, e com as devidas referências à petição inicial trabalhista, notoriamente menos formal do que a do CPC. Ademais, a simplicidade da delimitação do objeto do processo pelo pedido do autor salta aos olhos quando se pensa nas possíveis respostas do réu, como a contestação e a reconvenção, que têm o condão de trazer aos autos novos fatos e argumentos jurídicos. Com base nestes estudos, será feita uma tentativa de apontar com mais precisão até onde pode ir a atuação judicial.

\subsubsection{Requisitos da Petição Inicial e a Congruência}

Como bem salienta Fredie Didier Jr., a petição inicial não é a demanda, mas sim sua forma, seu instrumento ${ }^{128}$. Trata-se de distinção relevantíssima, uma vez que, conforme se viu, a "tradução" do conflito social em conflito judicial é justamente a passagem da demanda para a petição inicial e o processo efetivo busca aproximar a resolução dos dois conflitos, sendo presumível que, para tanto, se procure deixar a menor fresta possível entre a demanda e a petição inicial. Assim, pode o legislador assumir duas posturas: ou criar uma série de requisitos para que a exordial seja completa ou deixar a cargo do julgador suprir eventuais falhas, dando prioridade ao conteúdo (demanda) em detrimento da forma (petição inicial). No Brasil, o Processo Civil aproximou-se mais da primeira solução artigo 282 do CPC -, enquanto o Processo do Trabalho adotou a simplicidade como característica da petição inicial trabalhista ${ }^{129}$ - artigo 840 da CLT.

Não é o objetivo deste trabalho fazer uma análise minuciosa dos requisitos da petição inicial, de modo que apenas alguns deles serão abordados, sempre sob a perspectiva da congruência, para que sejam estabelecidos quais os elementos constantes desta peça tão importante de fato limitam a atividade jurisdicional.

\footnotetext{
${ }^{128}$ DIDIER JUNIOR, Fredie. Curso de direito processual civil, p. 397.

129 Aqueles que atuam na Justiça do Trabalho da $2^{\mathrm{a}}$ Região podem ter razoáveis dúvidas quanto à simplicidade da petição inicial, face à longa lista de exigências prevista no Provimento GP/CR nº 13/2006 do referido tribunal, que prevê até mesmo o tamanho do papel a ser utilizado e a quantidade de furos. Ainda que seja louvável a iniciativa para padronizar as reclamações, há que se frisar que a falta de cumprimento de tais exigências não pode, de forma alguma, obstar o acesso ao órgão judicial, desde que sejam atendidos os requisitos legais. A recusa de distribuição de petição inicial que não cumpra as formalidades do provimento constitui verdadeira usurpação de função pública, pois significaria o indeferimento liminar da inicial por servidor!
} 


\subsubsection{Forma}

Talvez uma das principais diferenças entre o Processo Civil e o trabalhista seja a necessidade de forma escrita da petição inicial no primeiro ${ }^{130}$, em oposição à possibilidade de reclamação verbal do segundo. Há que se esclarecer, antes de tudo, que mesmo a reclamação verbal trabalhista é reduzida a termo, de modo que o juiz recebe um documento escrito: ou seja, a oposição entre petição escrita e petição verbal supera a mera questão da forma. De fato, a previsão de capacidade postulatória do reclamante tem fundamento principiológico no acesso à justiça, tanto é que foi absorvida pelo Processo Comum, prevista nos processos dos Juizados Especiais: para Isis de Almeida, "o exercício do jus postulandi pela própria parte constitui corolário da tutela jurídica que recebe o trabalhador, compensando a sua hipossuficiência face à superioridade econômica do empregador"131.

Como descrito na Introdução, a utilização do ius postulandi durante o período de estágio no Departamento Jurídico XI de Agosto foi uma das inspirações desta dissertação, pois a alta demanda de processos levava os estagiários a apenas darem instruções aos reclamantes, para que se dirigissem sozinhos ao fórum. Há que se reconhecer, contudo, que atualmente o uso de tal expediente diminuiu sensivelmente, havendo até mesmo quem se oponha à manutenção dessa possibilidade. Neste sentido, Luis Henrique Simão Godeghesi diz que

\footnotetext{
a ampliação da competência da Justiça do Trabalho tornou insustentável a permanência do ius postulandi, eis que o instituto, ao ser utilizado, torna o processo menos efetivo, exacerba a desigualdade entre as partes e as afasta dos objetivos basilares da Constituição Federal quanto à ordem jurídica justa ${ }^{132}$.
}

Em que pese a evidente vantagem de ter a assistência técnica de advogado, não se comunga da opinião do caro amigo, pois a ampliação da capacidade postulatória é medida de facilitação de acesso ao Judiciário, em especial no que concerne às causas de menor complexidade e valor. Ademais, é possível vislumbrar soluções para sanar as deficiências decorrentes da ausência de advogado por outro ângulo, qual seja, pela atuação do juiz.

\footnotetext{
${ }^{130}$ A Lei $\mathrm{n}^{\text {o }} 9.099$ de 26 de setembro de 1995, em seu artigo 14, prevê a possibilidade de pedido oral nos Juizados Especiais. Trata-se, contudo, de norma especial, destinada ao processo mais célere, subsistindo, como regra geral, a forma escrita.

131 ALMEIDA, Isis de. O 'Jus Postulandi' das Partes na Justiça do Trabalho e os Princípios Básicos do Direito do Trabalho. Revista da Academia Nacional de Direito do Trabalho, São Paulo, n. 03, p. 85-89, 1995.

${ }^{132}$ GODEGHESI, Luis Henrique Simão. A ampliação da competência da justiça do trabalho e seus impactos no 'ius postulandi'. São Paulo, 2009. 112 f. Dissertação (Mestrado em Direito do Trabalho) - Faculdade de Direito da Universidade de São Paulo. Orientação do Prof. Ari Possidonio Beltran. p. 98.
} 
O autor supracitado, em pesquisa de campo, teve a oportunidade de observar a postura de magistrado perante reclamante desacompanhado de advogado:

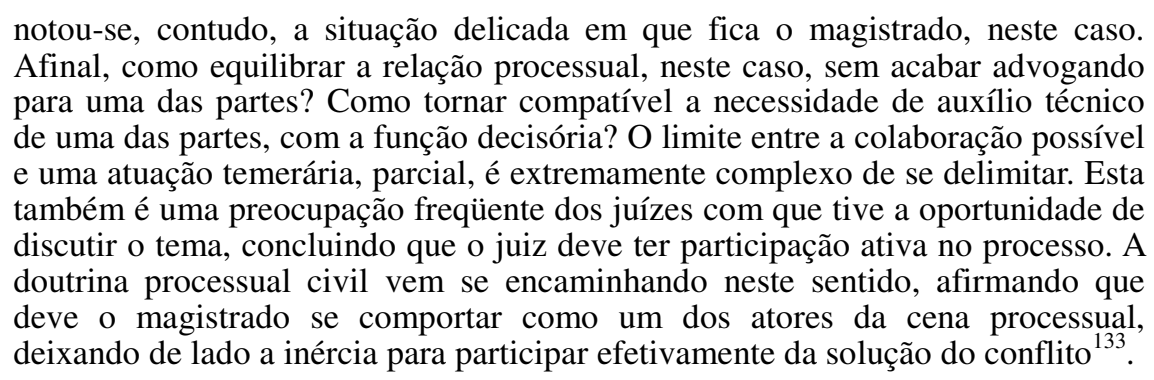

Ora, é inegável que a necessidade de auxílio técnico ao reclamante não se limita à audiência, sendo de se esperar que a petição inicial apresentada verbalmente e reduzida a termo seja caracterizada pela simplicidade da exposição dos fatos e do pedido. Aliás, como bem aponta Homero Batista Mateus da Silva, "a reclamação trabalhista é apenas verbal no sentido de o trabalhador pedir ajuda aos servidores da Justiça do Trabalho para redução a termo" ${ }^{134}$, de modo que a elaboração da causa de pedir e do pedido, em muitos casos, fica a critério do servidor. Pode o magistrado considerar, então, que a reclamação assim elaborada tem o mesmo grau de tecnicidade que a elaborada por advogado legalmente habilitado ${ }^{135}$ ? De modo algum. Por esse motivo, é imperativa a flexibilização do princípio da congruência ${ }^{136}$.

Por outro lado, não se pode admitir que a mera presença de advogado possa afastar a atuação judicial para a efetiva solução do conflito, especialmente quando se fala em Direito do Trabalho, cujas normas são, em sua maioria, de ordem pública. Além disso, a simplicidade é também característica da reclamação escrita, normalmente apresentada por advogado.

Assim, mais relevante do que o efetivo uso do jus postulandi é o seu significado axiológico de acesso à justiça e desburocratização dos procedimentos judiciais, característicos das sociedades democráticas modernas. $\mathrm{O}$ acompanhamento da parte por advogado qualificado não deve servir como impeditivo à atuação positiva do juiz, mas sim como estímulo para a boa administração da justiça. Mais uma vez, o processo não é um

\footnotetext{
${ }^{133}$ GODEGHESI, Luis Henrique Simão. A ampliação da competência da justiça do trabalho e seus impactos no 'ius postulandi', p. 76 e 77.

${ }^{134}$ SILVA, Homero Batista Mateus da. Curso de Direito do Trabalho Aplicado: Processo do Trabalho. São Paulo: Elsevier, 2010. p. 332. Grifo ausente no original.

${ }^{135}$ Não se pretende, de modo algum, desmerecer o trabalho dos servidores do setor de reclamação verbal da Justiça do Trabalho, em especial os do Fórum Rui Barbosa, que atenderam inúmeros casos encaminhados pelo DJ XI de Agosto. Contudo, é fato que a contratação de advogado envolve não apenas a expectativa de um trabalho de qualidade, mas também a responsabilização do profissional por eventuais negligências, imperícias ou imprudências na condução do processo.

${ }^{136}$ Neste sentido, é exemplar a legislação mexicana. Ver nota $n^{\circ} 77$.
} 
jogo, no qual ganha quem estiver mais bem preparado: é método estatal de resolução de conflitos, os quais, por vezes, envolvem questões de sobrevivência e dignidade das partes, razão pela qual há que se abandonar a concepção bélica do processo.

\subsubsection{Endereçamento}

O endereçamento ao juízo ou tribunal competente é requisito da petição civil e da petição escrita trabalhista, não havendo menção a tal requisito quando se tratar de reclamação verbal. Não obstante as diversas questões acerca deste requisito, deve-se tratálo com parcimônia: a competência é questão processual, sendo regra de ordem pública, de modo que o juiz pode e deve declarar-se incompetente e enviar os autos, de ofício, ao juízo correto $^{137}$, não sendo exigido da parte que emende a inicial para corrigir o endereçamento antes da remessa. Ou seja, não fica o juiz adstrito à indicação de juízo feita pelo autor, cabendo ao próprio magistrado determinar para onde devem ir os autos, tarefa nem sempre fácil, que pode levar à instauração de conflito de competência, decidido pelo órgão judicial determinado pela lei ${ }^{138}$, sem que haja qualquer possibilidade de interferência das partes.

No caso da reclamação verbal, o termo é encaminhado à Vara do Trabalho pelos servidores da Justiça do Trabalho.

\subsubsection{Qualificação das Partes}

A qualificação das partes é requisito de extrema importância, pois é a exteriorização de um dos três elementos identificadores da ação, qual seja, as partes, fundamental para que sejam definidos o alcance da sentença e a existência de conexão, litispendência ou coisa julgada.

A identificação do reclamante não comporta nenhuma polêmica. Há que se concordar com Jorge Luiz Souto Maior, que rejeita a aplicação subsidiária do CPC no caso dos requisitos para a qualificação das partes, por considerá-la desnecessária, já que "não há propriamente uma omissão e sim o reconhecimento de que a identificação da parte compete a quem está incumbido de fazê-lo, ou seja, o reclamante"139.

\footnotetext{
${ }^{137}$ Artigo 112, parágrafo único, do CPC.

${ }^{138}$ Artigo 115 e ss. do CPC e artigo 804 e ss. da CLT.

${ }^{139}$ SOUTO MAIOR, Jorge Luiz. Petição Inicial. São Paulo: LTr, 1996. p. 257.
} 
No tocante à qualificação do reclamado, em geral pessoa jurídica, é que podem surgir alguns problemas relativos à congruência: imagine-se que o trabalhador proponha ação em face da empresa $\mathrm{A}$, que responde a ação requalificando-se como empresa $\mathrm{C}$, em razão de eventual fusão com a empresa B: deve o juiz determinar a emenda da inicial para que o reclamante corrija o polo passivo ou está autorizado a proferir sentença em face da empresa $\mathrm{C}$, mesmo que todos os pedidos tenham sido dirigidos à empresa $\mathrm{A}$ ? A rigor, não se poderia admitir a segunda solução, pois o artigo 1.119 do Código Civil diz que "a fusão determina a extinção das sociedades que se unem, para formar sociedade nova, que a elas sucederá nos direitos e obrigações" ${ }^{140}$, de forma que, ao proferir sentença em face da empresa C, o juiz estaria julgando além dos limites da ação. Não obstante, é deste modo que se procede na Justiça do Trabalho, por força do artigo 10 da CLT - "Qualquer alteração na estrutura jurídica da empresa não afetará os direitos adquiridos por seus empregados". Nota-se, portanto, que a qualificação do réu no Processo Trabalhista é revestida de menos formalidades do que no Processo Civil, prevalecendo o princípio da realidade dos fatos.

Se na fase de conhecimento a questão descrita é sanada pela efetiva participação da empresa $C$ no contraditório - e mesmo pela apresentação de contestação sem alegação de ilegitimidade de parte - o mesmo não se pode dizer do reconhecimento de sucessão trabalhista ou de grupo econômico em fase de execução, quando já há sentença proferida em face de apenas um empregador. Aplicar-se-ia também, nestes casos, o artigo 10 da CLT? Não estaria o juiz incorrendo em uma incongruência em fase de execução ou estaria o magistrado autorizado a assim proceder em razão na natureza da norma que garante o direito adquirido dos empregados? Trata-se de questão intrigante, que será brevemente abordada quando se tratar de congruência na fase de execução.

\subsubsection{Causa de Pedir}

Segundo elemento da ação, a causa de pedir é ponto de divergência entre o Processo Comum e o Trabalhista. Enquanto o CPC exige que o autor apresente "os fatos e o fundamento jurídicos" $" 141$ do pedido, a CLT requer apenas "uma breve exposição dos fatos de que resulte o dissídio" ${ }^{\text {142 }}$. Jorge Luiz Souto Maior ${ }^{143}$ questiona se tal diferença

\footnotetext{
${ }^{140}$ Grifo ausente no texto da lei.

${ }^{141}$ Artigo 282, III, do CPC

${ }^{142}$ Artigo 840, $\S 1^{\circ}$, da CLT.
} 
autoriza a se considerar que o Processo Trabalhista adota a teoria da individualização, em vez da teoria da substanciação, adotada pelo Processo Comum.

Fredie Didier Jr. afirma categoricamente que o CPC alinha-se à teoria da substanciação, pois exige que o autor indique o fato jurídico e a relação jurídica dele decorrente $^{144}$. No mesmo sentido, Humberto Theodoro Jr. afirma que a menção aos fatos e ao fundamento jurídico do pedido "torna evidente a adoção do princípio da substanciação da causa de pedir" ${ }^{\prime 45}$. Pela teoria da individualização, por outro lado, a causa de pedir depende apenas da mera alegação de relação jurídica entre as partes. Na seara trabalhista, Carlos Henrique Bezerra Leite sustenta que o processo também segue a teoria da substanciação, em consonância com o Processo Comum, pois

\begin{abstract}
não é suficiente que o empregado simplesmente alegue que é sujeito da relação de emprego (relação jurídica material) e formule pedido de anotação da CTPS (teoria da individualização), pois o nosso direito positivo exige que o demandante justifique a razão pela qual afirma que é sujeito da relação de emprego $^{146}$.
\end{abstract}

Antes de prosseguir no embate das duas teorias, há que se considerar a sua pertinência: Othmar Jauernig afirma que "a velha teoria da individualização e sua réplica, a teoria da substanciação, estão ultrapassadas"147. Na doutrina pátria, vozes também se levantam nesse mesmo sentido ao defenderem que o sistema brasileiro encontrou um ponto de equilíbrio entre as duas teorias, "dando importância tanto aos fatos constitutivos, como aos elementos de direito, na medida em que sirvam para individualizar a pretensão do autor" ${ }^{148}$. Assim é que responde Jorge Luiz Souto Maior ao questionamento por ele mesmo formulado, concluindo que apenas a conjunção das duas teorias é que dá a medida da causa de pedir, aplicando tal entendimento ao Processo do Trabalho, com a ressalva de que, neste, a indicação dos fatos constitutivos da relação jurídica é exceção, enquanto no Processo Comum ela é a regra ${ }^{149}$.

Quais fatos, então, devem ser brevemente expostos na petição inicial trabalhista? Para Homero Batista Mateus da Silva ${ }^{150}$ e Jorge Luiz Souto Maior ${ }^{151}$, devem ser expostos

\footnotetext{
${ }^{143}$ SOUTO MAIOR, Jorge Luiz. Petição Inicial, p. 285.

${ }^{144}$ DIDIER JUNIOR, Fredie. Curso de direito processual civil, p. 400.

145 THEODORO JUNIOR, Humberto. Curso de direito processual civil. v. 1. Rio de Janeiro: Forense, 2002. p. 314.

${ }^{146}$ BEZERRA LEITE, Carlos Henrique. Curso de direito processual do trabalho, p. 426.

${ }^{147}$ JAUERNIG, Othmar. Direito processual civil. Coimbra: Almedina, 2002. p. 206.

148 Ver BOTELHO DE MESQUITA, José Ignácio. A ‘causa petendi’ nas ações reivindicatórias. Revista de Direito Processual Civil, São Paulo, ano III, v. 6, p. 183-198, 1962.

149 "Com efeito, a relação jurídica básica trabalhista, a relação de emprego, se forma, unicamente, pela conjugação de três elementos fáticos, inscritos nos artigos $2^{\circ}$ e $3^{\circ}$ da CLT”. Ver SOUTO MAIOR, Jorge Luiz. Petição Inicial, p. 285.

${ }^{150}$ SILVA, Homero Batista Mateus da. Curso de Direito do Trabalho Aplicado, p. 333.
} 
os fatos simples, aptos a identificar a relação jurídica das partes e o pedido a seguir formulado, sem necessidade de fundamentação jurídica, ao contrário do que ocorre no Processo Civil. A consequência da dispensa de tal exigência é a permissão ao magistrado para que julgue "o pedido pelos fundamentos que melhor lhe pareçam aplicáveis à espécie, independentemente da eleição formulada pelo reclamante, ou mesmo no caso de omissão a respeito" 152 .

Tal hipótese é, verdadeiramente, uma flexibilização do princípio da congruência em vigor no Processo Civil. José Rogério Cruz e Tucci aduz que "não é lícito à parte alterar a 'causa petendi', nem ao juiz julgar procedente a ação por fundamento diverso daquele deduzido pelo autor" ${ }^{, 153}$. No Processo do Trabalho, com efeito, o juiz não pode julgar com base em fatos não alegados pelas partes, o que feriria o contraditório, mas está livre para fundamentar juridicamente a sentença do modo que lhe pareça mais adequado. Assim, ao juiz trabalhista é permitido condenar subsidiariamente a tomadora de serviços, mesmo quando o reclamante tenha apenas indicado a responsabilidade solidária como fundamento de sua pretensão, ou conhecer de rescisão indireta com o fundamento de ter o empregador exigido serviço superior às forças do empregado em vez de ter descumprido suas obrigações contratuais, se assim restar provado na instrução.

A dispensa do fundamento jurídico da pretensão e a liberdade do juiz são elementos diretamente ligados à natureza da relação material típica trabalhista, que é a relação de emprego. Considerando que as normas da CLT são, em regra, indisponíveis, não se poderia admitir que o juiz, ciente da existência de fundamento jurídico diverso para a pretensão do reclamante, pretensão essa fundamentada em norma de ordem pública, simplesmente fechasse os olhos. Daí a CLT ter optado por não repetir a exigência do CPC, evitando esse tipo de celeuma.

Por outro lado, até que ponto a breve exposição dos fatos da inicial trabalhista tem o condão de dispensar a formulação do pedido? Seria possível considerar pedido formulado apenas na causa de pedir, mesmo que não conste do rol final? Afinal de contas: onde está o pedido?

\footnotetext{
${ }^{151}$ SOUTO MAIOR, Jorge Luiz. Petição Inicial, p. 286.

${ }^{152}$ Ibidem, p. 287.

${ }^{153}$ CRUZ E TUCCI, José Rogério. A 'causa petendi' no processo civil. São Paulo: Revista dos Tribunais, 2001. p. 205. Grifo ausente no original.
} 


\subsubsection{Pedido}

O pedido é o terceiro elemento identificador da ação e já foi analisado quando se estudou a lide em seu objeto, no Capítulo 2, trazendo o entendimento tradicional da doutrina. Assim, para evitar repetições desnecessárias, abordar-se-ão apenas algumas questões específicas ainda não contempladas.

Como já foi visto, são características do pedido a certeza e a determinação, não sendo admitido, em regra, o pedido genérico, nem pedido vago, como "condenar o réu nas penas da lei". Trata-se de entendimento processual civilista, que foi incorporado pelo Processo do Trabalho. Contudo, há que se notar o seguinte: enquanto a lide civil, em regra, debruça-se sobre um bem da vida com consequências restritas (p. ex. em uma ação de despejo, a causa de pedir pode ser a falta de pagamento e o pedido é a entrega do bem e o pagamentos das parcelas vencidas), a lide trabalhista, notadamente a que se refere ao contrato de trabalho, costuma ter uma série de consequências, decorrentes do descumprimento de tal contrato: assim, são comuns as petições iniciais com mais de dez itens de pedidos, pois a cada direito trabalhista corresponde um pedido, ou seja, o inverso da lide civil, em que há uma causa de pedir (o descumprimento do contrato) e dezenas de pedidos. Tal é a praxe. Porquanto a mudança da praxe não possa ser operada no âmbito da academia, cabe discutir a sua pertinência.

Em primeiro lugar, um problema de ordem prática: a suposta necessidade de elencar, um por um, os direitos trabalhistas decorrentes de um contrato sujeita aquele que formula a inicial - advogado ou reclamante - a um rigor extremo, incompatível com o espírito do Processo do Trabalho. Não se pode admitir, por exemplo, que a omissão no rol dos pedidos do pagamento do terço constitucional, havendo pedido de pagamento das férias, impeça o magistrado de conceder tal verba, especialmente se se considerar que se trata de um direito indisponível. A indisponibilidade, aliás, é o ponto central de toda a discussão da formulação do pedido.

As consequências legais do contrato de trabalho são de conhecimento geral, conforme preconiza o artigo $3^{\circ}$ da LICC, e independem, na sua maioria, da vontade das partes. Ou seja, uma vez estabelecido o vínculo empregatício, há direitos e deveres que devem ser obrigatoriamente observados. Diante desse quadro, é possível se falar em inépcia da inicial, por formulação de pedido incerto e indeterminado, se o reclamante pleiteia apenas o cumprimento do contrato de trabalho? Não se pode responder a essa 
pergunta sem antes fazer outros dois questionamentos: o pedido de cumprimento do contrato de trabalho é logicamente decorrente da causa de pedir? A narração dos fatos traz ao réu e ao julgador, que conhecem a legislação trabalhista, a medida do pedido? Em caso positivo, não há motivo para se negar a tutela ao autor, pois as consequências do contrato de trabalho não podem ser moduladas de acordo com a vontade do reclamante. Trata-se de uma espécie de jogo de tudo ou nada, ressaltando-se que é dele o ônus de indicar eventuais direitos contratuais e convencionais não decorrentes de lei.

Assim, há que se relativizar a importância do rol de pedidos no Processo do Trabalho, buscando-se identificar os pedidos, a exemplo da magistrada supracitada, também na causa de pedir. É evidente medida de resguardo dos direitos trabalhistas, pois evita que o reclamante fique privado de direito indisponível por omissão involuntária ou falta de técnica de seu advogado ${ }^{154}$, devendo o réu, em sua contestação, concentrar-se em fazer defesa dos fatos, comprovando ter cumprido integralmente suas obrigações contratuais.

Esse entendimento, a rigor, não importa em flexibilização do princípio da congruência, pois, ao buscar o pedido na causa de pedir, o juiz, ainda assim, estará julgando nos limites do pleiteado.

\subsubsection{Valor da Causa}

Requisito expresso da petição inicial da justiça comum, o valor da causa não aparece no rol do artigo 840 da CLT. Seria errôneo, contudo, presumir que à causa trabalhista não deve ser dado valor: o artigo 852-A da norma laboral estabelece que se processam pelo rito sumaríssimo as ações que não excedam 40 salário mínimos, do que se conclui que a indicação do valor da causa deve ser feita sempre, para que se possa determinar o rito da ação.

Questão relevante é se o valor dado à causa vincula o juiz, que deveria, então, limitar a execução aos valores constantes da inicial. Decerto que não se pode acatar tal

\footnotetext{
${ }^{154}$ Exemplo notável é o apontado por Jorge Luiz Souto Maior: “(...) parece-me excessivamente formalista a distinção de pedido de anotação em CTPS de pedido de declaração do reconhecimento de vínculo empregatício. O pedido de anotação em CTPS já traz consigo, indissoluvelmente, o pedido de declaração de vínculo, até mesmo porque da declaração de vínculo decorre inexoravelmente, mesmo sem pedido expresso nesse sentido, a determinação de anotação da CTPS (art.39, $\S 1^{\circ}$ da CLT). Trata-se, ademais, de iniciativa que deva ser tomada 'ex oficio' pelo juiz até mesmo antes da prolação da sentença, quando não houver controvérsia quanto ao vínculo (art.39, $\$ 2^{\circ}$ da CLT)". Ver SOUTO MAIOR, Jorge Luiz. Inépcia da inicial pedido de declaração de vínculo empregatício. In: LTr, 2000. p. 28 e 29. (Org.). Temas de processo do trabalho. São Paulo:
} 
posição. No processo sumaríssimo trabalhista, há obrigação explícita de indicação do valor do pedido, mas inexiste obrigação de proferimento de sentença líquida ${ }^{155}$, de forma que o magistrado pode apenas determinar as verbas deferidas e o seu modo de cálculo, deixando para a fase de execução a apuração dos valores monetários da condenação. Com menos razão se poderia entender pela adstrição da sentença aos valores indicados na petição inicial do processo ordinário, situação que exigiria que os advogados tivessem formação em contabilidade também, dada a complexidade dos cálculos trabalhistas.

\subsubsection{Provas a Serem Produzidas}

O CPC é claro ao elencar, entre os requisitos da petição inicial, a indicação das provas que o autor pretende produzir ${ }^{156}$, exigência que leva a maioria dos advogados a inserir um texto padrão ao final de suas peças, protestando pela "produção de todas as provas admitidas em direito", como se o juiz fosse deferir provas não admitidas... Tal requisito não se repete na CLT e Carlos Henrique Bezerra Leite entende desnecessária a aplicação subsidiária do CPC, "porquanto as provas são geralmente produzidas em audiência, sendo certo que, via de regra, o autor somente após a defesa saberá precisar o objeto da controvérsia" ${ }^{, 157}$.

Não poderia ter mais razão o ilustre professor, especialmente se se considerar que a liberdade para a determinação de produção de provas é a menina dos olhos do poder jurisdicional, provavelmente umas das primeiras amarras das quais se soltou o juiz do processo moderno, libertando-se da tradição defendida por Francisco Cavalcanti Pontes de Miranda, que chegou a afirmar que tal poder equivale a "quebrar toda a longa escadaria que se subiu através de 150 anos de civilização" ${ }^{158}$. Atualmente, prevalece a noção de que o juiz deve dirigir o processo, com vistas à solução do conflito, que será tanto mais satisfatória quanto mais elementos o julgador tiver à sua disposição para proferir a sentença. Ressalta-se que o juiz não atua a favor de nenhuma das partes - cujas provas são requeridas apenas de acordo com o próprio interesse -, mas sim para atender o interesse

\footnotetext{
${ }^{155}$ Nota-se que a inexistência dessa exigência é proposital, uma vez que a redação original do Projeto de Lei $\mathrm{n}^{\circ} 28$ de 1999, que deu origem à Lei $\mathrm{n}^{\circ} 9.957$ de 12 de janeiro de 2000, previa dispositivo proibindo a sentença ilíquida, objeto de veto presidencial, conforme Mensagem $\mathrm{n}^{\circ} 75$ de 12 de janeiro de 2000 .

${ }^{156}$ Artigo 282, IV, do CPC.

${ }^{157}$ BEZERRA LEITE, Carlos Henrique. Curso de direito processual do trabalho, p. 441.

${ }^{158}$ PONTES DE MIRANDA, Francisco Cavalcanti. Comentários ao Código de Processo Civil, p. 514.
} 
geral da correta aplicação da norma, justificando-se, desse modo, a iniciativa oficial para a produção probatória. De acordo com José Roberto dos Santos Bedaque,

ninguém melhor do que o juiz, a quem está afeto o julgamento, para decidir sobre a necessidade de produzir determinada prova. Nesta medida, e considerando o escopo da atividade jurisdicional, a colheita de elementos probatórios interessa tanto ao juiz quanto às partes ${ }^{159}$.

Assim, o juiz não está adstrito - nem positiva nem negativamente - ao requerimento de provas das partes, pois pode indeferir as provas expressamente pedidas, bem como exigir a produção daquelas não aventadas pelo autor ou pelo réu, podendo utilizar estas últimas como fundamento da sentença, não se havendo que falar em extrapolação dos limites da lide nesse caso.

\subsubsection{Requerimento de Citação do Réu}

Assim como o item anterior, não há na CLT exigência de requisição de citação notificação, na linguagem usada pela lei laboral - do réu. Apesar de não ser item determinante da sentença, a dispensa de tal requisição na reclamação trabalhista é exemplar: o chamamento do réu ao processo é conditio sine qua non para a sua própria existência, é ato processual que só pode ser realizado pelo poder público sendo absolutamente descabido o indeferimento de petição inicial, mesmo civilista, que omita tal pedido. Também há que se discordar de Vallisney de Souza Oliveira, que entende pela necessidade de determinação de emenda da inicial para que o autor explicite a intenção de citar o réu ${ }^{160}$, pois o juiz, como condutor do processo, deve atuar para que haja uma conclusão, garantindo o acesso à justiça e o contraditório, motivo pelo qual se entende que a citação do réu pode ser feita de ofício. Decerto, tal discussão é desnecessária no âmbito do Processo do Trabalho, que de forma brilhante dispensou o pedido de notificação do réu, deixando que a Secretaria da Vara tome as devidas providências.

Optou-se, porém, por analisar este item para adiantar a discussão que será aprofundada mais adiante, relativa à não aplicação do princípio da congruência quando se busca promover os valores que informam o processo, no caso, a economia processual e o acesso à justiça.

\footnotetext{
${ }^{159}$ BEDAQUE, José Roberto dos Santos. Poderes instrutórios do juiz, p. 15.

${ }^{160}$ OLIVEIRA, Vallisney de Souza. Nulidade da sentença e o princípio da congruência, p. 139.
} 


\subsubsection{Respostas do Réu}

Genericamente, chamam-se as respostas do réu de exceções, havendo quem as divida em exceções processuais em sentido amplo - que correspondem ao direito de defesa - e em sentido estrito - que dizem respeito unicamente às matérias de defesa que não podem ser conhecidas de ofício pelo juiz e estão sujeitas à preclusão ${ }^{161}$. Interessa, a este trabalho, o modo pelo qual a resposta do réu pode alargar o campo de cognição judicial, razão pela qual se focará exclusivamente na exceção mais conhecida: a contestação ${ }^{162}$.

A contestação, prevista no artigo 300 do CPC e no artigo 847 da CLT, não encontra tanto requisitos legais de admissibilidade quanto a petição inicial, embora deva obedecer a algumas regras para poder surtir os efeitos desejados: também deve ser clara e precisa, apresentando os fatos que o réu julgar adequados ao convencimento do juiz. Assim, a contestação, diz-se, pode ser de dois tipos: (i) processual e (ii) de mérito. A defesa processual, bem detalhada no artigo 301 do CPC, em regra, traz matérias que podem ser conhecidas de ofício pelo juiz, dada a natureza pública das questões envolvidas, pois dizem respeito ao bom andamento do processo, responsabilidade do juiz. O conhecimento de ofício de matéria processual será analisado no item 3.4. A defesa substancial, contudo, é que interessa mais ao estudo do princípio da congruência.

Diz Fredie Didier Jr. que a "a exceção substancial, para ser conhecida pelo juiz, precisa ser exercida pelo demandado" ${ }^{163}$. Como já visto, a exceção substancial é a defesa material do réu, que traz aos autos os fatos que considera relevantes. Há que se considerar que, por uma questão de isonomia, a defesa material do réu no Processo do Trabalho deve ser entendida apenas como a narração dos fatos, não se podendo exigir que apresente a fundamentação jurídica da sua pretensão. Desse modo, é inaplicável ao Processo Laboral o entendimento de Vallisney de Souza Oliveira no sentido de que a falta de ataque ou negação das consequências jurídicas fazem presumir a concordância do réu com o direito invocado pelo autor ${ }^{164}$. Ao réu cabe fazer defesa fática minuciosa, em razão da regra da eventualidade, que sustenta que a defesa não pode ser genérica e deve ser feita toda de uma vez, apresentando-se todos os fatos em um único ato, sob pena de preclusão consumativa -

\footnotetext{
${ }^{161}$ Ver DIDIER JUNIOR, Fredie. Curso de direito processual civil, p. 469.

162 À reconvenção, que não é mais nada do que uma ação dentro de outra ação, aplica-se o já exposto no item que tratou da petição inicial.

${ }^{163}$ DIDIER JUNIOR, Fredie. Curso de direito processual civil, p. 470.

${ }^{164}$ Ver OLIVEIRA, Vallisney de Souza. Nulidade da sentença e o princípio da congruência, p. 152.
} 
o que acaba gerando, por vezes, contestações contraditórias. Contudo, a exemplo do que se sustentou ao se discorrer sobre a petição inicial, entende-se possível ao juiz conhecer de questões não suscitadas pelo réu, ainda que relativas à exceção substancial, se assim a lei lhe permitir: o melhor exemplo dessa hipótese é o reconhecimento da prescrição, alçada ao nível de norma de caráter público em virtude de recente alteração do artigo 219 do Código Civil, pela Lei $\mathrm{n}^{\mathrm{o}} 11.280$ de 16 de fevereiro de 2006, que permitiu ao juiz conhecer de ofício a prescrição, mesmo sem manifestação das partes nesse sentido ${ }^{165}$. Mais relevante, contudo, é saber se e como a narrativa do réu pode impactar o princípio da congruência. Trata-se de tema não muito explorado, tendo em vista a ideia tradicional de que o juiz está adstrito ao pedido do autor - como se o réu também não formulasse pedidos... Antes de passar aos pedidos do réu, devem ser estudados os fatos que são trazidos aos autos pela defesa.

Além de negar os fatos narrados pelo autor, o réu também pode trazer ao processo fatos novos: de acordo com o artigo 326 do CPC, tais fatos podem ser (i) modificativos; (ii) impeditivos; ou (iii) extintivos da pretensão do autor. Enquanto estes últimos, se provados, levam à extinção do processo com resolução de mérito, o mesmo não se pode necessariamente dizer dos fatos modificativos. Tais são os argumentos do réu que visam modificar a relação jurídica entre as partes, dando nova consequência jurídica à lide, diversa do pleiteado. Não há dúvidas acerca da possibilidade de conhecimento, pelo juiz, dos fatos trazidos aos autos pelo réu para a formação de seu convencimento e prolação da sentença, pois tal é o teor do artigo 128, a contrario sensu. Contudo, cabe explorar algumas questões.

Pode o juiz, em razão das provas produzidas, conhecer de fato modificativo ou impeditivo não alegado pelo réu? A mais nobre característica do processo moderno é a busca da isonomia; há que se permitir ao juiz conhecer de tais fatos, em homenagem ao princípio da busca da verdade real, não se podendo admitir que tal busca se dê apenas em favor do autor - em geral, o empregado - sem favorecer também o réu, se assim for o caso. Desse modo, é lícita a decisão do juiz que indefere verba trabalhista já paga com base em

\footnotetext{
${ }^{165}$ Tal alteração legislativa é exemplificativa do papel da concepção de Estado na determinação dos poderes do juiz: a redação anterior do $\S 5^{\circ}$ do artigo 219 do Código Civil dispunha que "não se tratando de direitos patrimoniais, o juiz poderá, de ofício, conhecer da prescrição e decretá-la de imediato". Ou seja, da redação original, extrai-se que a prescrição, quando se tratava de direitos patrimoniais, era questão privada - das partes - e o juiz só poderia dela conhecer caso isso fosse alegado pelo réu. A alteração legislativa, sem sombra de dúvida, incorporou nova exceção ao princípio da vinculação da sentença, publicizando um instituto tradicionalmente privado.
} 
confissão do autor, eventualmente confirmada por testemunha, mesmo que não haja tal alegação na narrativa da contestação. De outro modo, estar-se-ia premiando o enriquecimento ilícito, situação vedada pelo ordenamento jurídico.

Pode o juiz basear-se em fato novo, alegado pelo réu, para fundamentar a pretensão do autor? Mais uma vez, com base no princípio da busca da verdade real, não se pode admitir que os fatos alegados pelo réu apenas lhe favoreçam, mesmo porque, embora mais rara, o reconhecimento do pedido é modalidade de resposta do réu, podendo o magistrado conhecer de pretensão não bem fundamentada na inicial, mas reconhecida pelo réu. Nota-se, porém, que o reconhecimento do pedido ou a revelia não vinculam o juiz no sentido de lhe obrigar a julgar a inicial procedente: tal é o caso de verificação de colusão entre as partes (artigo 129 do CPC), que será estudada adiante, ou inverossimilhança das alegações do autor ${ }^{166}$.

Pode o juiz, com base em fato novo modificativo alegado pelo réu, conceder ao autor bem da vida de natureza diversa da pleiteada? Trata-se de questão polêmica e, para respondê-la, há que se fazer referência ao que foi tratado no item 3.2.2.1, quando se estudou o que fazer nos casos em que o juiz dá novo enquadramento jurídico à pretensão do autor, resultando em consequência jurídica diversa da pleiteada. Naquela ocasião, sugeriu-se, em razão do princípio da economia processual, abrir prazo às partes para que se manifestem. O mesmo se pode aplicar na hipótese de o réu trazer fato modificativo que não extingue a demanda, mas modifica suas consequências jurídicas. Ora, se o fato foi trazido aos autos pelo próprio réu, com nenhuma razão pode alegar violação ao contraditório!

Por fim, não se pode esquecer que também o réu formula pedido, mesmo em contestação. Assim sustenta Fredie Didier Jr.:

o réu também pode demandar, embora com pedidos bastante peculiares. Pode pedir o réu, em sua peça de defesa: a) a extinção do processo sem exame de mérito; b) a remessa dos autos ao juízo competente ou ao juízo prevento; c) a devolução do prazo de defesa; d) a improcedência do pedido do autor; e) a

\footnotetext{
166 Caso pitoresco de inverossimilhança das alegações do autor é o da Reclamação Trabalhista $n^{\circ}$ 04454200608902008, que tramitou perante a 89ª Vara do Trabalho de São Paulo. Ao rechaçar a pretensão do autor de ver reconhecida jornada de trabalho de vinte e quatro horas diárias, durante quatro anos, o magistrado Marcos Fava sentenciou: "a revelia não confirmaria que o reclamante trabalhava voando por sobre o telhado da empresa, como também não confirmaria que ele recepcionava extraterrestres, quando das visitas regulares dos marcianos à Terra. Não obstante a confissão da reclamada, por sua revelia, não vejo possibilidade de concessão dos títulos postulados. O processo não é um jogo de pega-pega, é instrumento de distribuição da justiça e de fixação dos parâmetros da cidadania e isto está acima do interesse privado de defesa do reclamado. Não pode o Judiciário reconhecer o impossível, sob pena de desrespeito à sociedade". Disponível em: <http://trt.trtsp.jus.br/dwp/consultasphp/public/index.php/sentenca>. Acesso em: 27 set. 2010.
} 
condenação do autor às verbas de sucumbência; f) a condenação do autor em litigância de má-fé $(. . .)^{167}$.

Pergunta-se se esses pedidos, a exemplo dos da inicial, devem ser formulados em rol a esse fim destinado ou se podem simplesmente constar da narrativa de contestação. A boa técnica vota pela segunda opção, mas a instrumentalidade do processo força à primeira, pois, na maior parte dos casos, trata-se de situações processuais, que podem ser conhecidas de ofício pelo juiz.

\subsection{Sentença}

O artigo 162 do CPC, em sua redação original, estabelecia que a sentença era o ato do juiz que punha termo ao processo, analisando ou não o mérito. Manoel Antonio Teixeira Filho critica tal definição, afirmando que nem sempre a prolação da sentença implica a extinção no processo, como na hipótese de interposição de recurso. Contudo, reconhece a finalidade prática do referido conceito, especificamente no tocante à determinação da espécie de recurso cabível ${ }^{168}$. No Processo do Trabalho, o tratamento sobre a sentença é praticamente o mesmo do Processo Comum e tal praticidade é ainda mais acentuada, tendo em vista a irrecorribilidade das decisões interlocutórias.

A Lei $n^{\circ} 11.232$ de 22 de dezembro de 2005 alterou a redação do artigo supracitado, passando a conceituar a sentença como o ato do juiz que (i) extingue o processo sem resolução de mérito ou (ii) resolve o mérito do processo. A doutrina chama a primeira de "sentença terminativa" e a segunda de "sentença definitiva"169.

A sentença terminativa pode acolher as preliminares de mérito previstas no artigo 267 do CPC, havendo consenso doutrinário acerca da possibilidade de conhecimento de ofício das matérias ali incluídas, com exceção da convenção de arbitragem, que deve ser alegada pelas partes para poder fundamentar a sentença terminativa. Não há surpresa nesse posicionamento, pois, como visto até agora, o princípio da congruência não é aplicado quando se trata de questões de ordem pública e a norma processual, em geral, apresenta tal caráter e deve ser aplicada pelo juiz, zelador do bom andamento processual. Deste modo, não há que se falar em adstrição da sentença à alegação, feita pelo réu, das hipóteses do artigo 267, mesmo porque a sentença terminativa pode ser prolatada até mesmo antes da

\footnotetext{
${ }^{167}$ DIDIER JUNIOR, Fredie. Curso de direito processual civil, p. 482.

168 TEIXEIRA FILHO, Manoel Antonio. A sentença no processo do trabalho. São Paulo: LTr, 2004. p. 202 e 203.

${ }^{169}$ Ver Ibidem, p. 204.
} 
citação. Nota-se, contudo, que permanece a obrigação de o juiz observar exclusivamente os elementos constantes dos autos, mesmo para proferir sentença terminativa.

A sentença de mérito, por sua vez, gera mais polêmica quando se analisa a aplicação do princípio da congruência, uma vez que seu objetivo é resolver o conflito material, havendo pronunciamento judicial sobre os fatos e as suas consequências jurídicas. Trata-se de decisão com efeitos mais profundos, porquanto a decisão de mérito está sujeita à imutabilidade pela coisa julgada, o que nem sempre ocorre com as sentenças terminativas. Isso significa que a sentença que resolve a lide, deferindo ou rejeitando pedidos não expressamente formulados pelas partes, pode levar a que tais questões também sejam abrangidas pela coisa julgada. Assim, a observância da natureza do direito discutido, para a determinação da possibilidade de conhecimento de ofício de questões de mérito, e do contraditório, é requisito essencial para o afastamento do princípio da congruência.

O CPC, em seu artigo 458, e a CLT, no artigo 832, preveem que a sentença deve conter os seguintes requisitos: (i) os nomes das partes; (ii) o resumo do pedido e da defesa; (iii) a apreciação das provas (iv) os fundamentos da decisão; e (v) a conclusão. Em termos técnicos, tais requisitos são o que se chama de relatório, motivação e dispositivo. São requisitos essenciais e sua ausência importa em nulidade da sentença ${ }^{170}$.

É possível estabelecer uma relação entre os elementos da petição inicial e os da sentença, mormente no que diz respeito à relação entre a causa de pedir e o relatório/motivação da sentença e entre o pedido e o dispositivo. Do mesmo modo que o pedido deve ser logicamente decorrente da causa de pedir e a ela adequado, a decisão judicial deve ser devidamente fundamentada (artigo 93, IX, da CF), sob pena de lhe serem opostos embargos de declaração para esclarecimentos dos fatos omissos, obscuros ou contraditórios $^{171}$. Contudo, tal analogia deixa a relação perfeita entre motivação e dispositivo da sentença à mercê da perfeita correlação entre a causa de pedir e o pedido na inicial, situação que, como visto, nem sempre ocorre.

Assim, imagine-se um caso em que o autor, na causa de pedir, sustenta ter trabalhado e ter sido dispensado sem justa causa, não tendo recebido aviso prévio nem a multa de $40 \%$ sobre os depósitos no FGTS, mas em seu pedido requer unicamente o pagamento da multa fundiária. Ao elaborar o relatório e a motivação, o juiz, forçosamente, haverá de reconhecer que o autor, tendo sido dispensado sem justa causa, faz jus às

\footnotetext{
${ }^{170}$ Não obstante, o artigo 852-I da CLT dispensa a formulação de relatório em sentença proferida em processo que tramita no rito sumaríssimo.

${ }_{171}$ Artigo 897-A da CLT e artigo 535 do CPC.
} 
consequências jurídicas de tal dispensa (entre elas, o pagamento de aviso prévio), indicando os fundamentos jurídicos e legais que regulam essa modalidade de rescisão contratual. Contudo, ao passar ao dispositivo, deferirá unicamente a multa fundiária. É admissível uma sentença que, em seu fundamento, reconhece a existência de um fato com consequências jurídicas indisponíveis, mas em seu dispositivo o ignora? Entre as hipóteses de oposição de embargos de declaração encontram-se a omissão e a contradição da sentença: a rigidez da correlação entre os elementos da petição inicial e os da sentença, como no caso em tela, pode levar ao proferimento de uma decisão judicial viciada! Há que sempre ter em mente que o objetivo do processo é a resolução de uma crise e a efetividade do Direito Material, não se podendo admitir que formalidades anacrônicas impeçam o efetivo acesso à justiça. Ademais, como bem aponta Manoel Antonio Teixeira Filho, a finalidade da sentença não é unicamente a aplicação do Direito, mas a busca da justiça:

(...) o juiz, nos conflitos individuais, deve aplicar a lei ao caso concreto, a despeito de poder dar-lhe uma interpretação que, sem desvirtuar-lhe o sentido, faça com que ela se torne mais justa, ou menos injusta, e, nisto, se insinua o contributo jurídico do magistrado para a indispensável adequação do sentido teleológico da norma à realidade social, política e econômica e às inomitíveis transformações orgânicas que esta apresenta ${ }^{172}$.

Apesar de seu louvável entendimento acerca da finalidade da sentença, o supracitado autor não partilha das ideias aqui esposadas, sustentando que a adequação da sentença refere-se à necessidade de a decisão judicial ater-se aos pedidos formulados pelas partes $^{173}$, posição doutrinária majoritária. A falta da observação de tal requisito pode levar ao proferimento de sentença ultra, extra ou citra petita. Nota-se, contudo, que, mesmo que se entenda o requisito de adequação em um sentido amplo, ainda assim tais vícios podem ser observados.

\subsubsection{Das Sentenças Citra, Ultra e Extra Petita}

A problemática da citra petição, ainda que diga respeito à congruência da sentença, foge do escopo deste trabalho, em que se estuda a possibilidade de flexibilização do princípio para que o juiz aumente o seu campo de cognição. A sentença citra petita é aquela que não aprecia toda a demanda, não se confundindo com a sentença que dá menos do que o autor pleiteia: esse é exatamente o caso das sentenças de parcial procedência ou total improcedência do pedido.

\footnotetext{
172 TEIXEIRA FILHO, Manoel Antonio. A sentença no processo do trabalho, p. 282.

${ }^{173}$ Ibidem, p. 331.
} 
O julgamento citra petita pode ser observado nas seguintes hipóteses: (i) o juiz deixa de apreciar pedido formulado pela parte; (ii) o juiz, embora apreciando o pedido, concede menos do que o legalmente previsto (p. ex. a parte pleiteia o adicional noturno de 20\%, nos termos do artigo 73 da CLT, e o juiz lhe concede 10\%); ou (iii) o juiz deixa de apreciar fato constitutivo, extintivo ou modificativo do direito das partes, inserido na causa de pedir. Trata-se de vício gravíssimo, pois, ao julgar desse modo, o magistrado está negando jurisdição às partes, restringindo-lhes o completo acesso à justiça e deixando o conflito mal resolvido. Ressalta-se, contudo, que a exigência de cognição exaustiva da matéria trazida aos autos deve ser sensata, não se exigindo, portanto, a manifestação sobre pedido sucessivo se o principal foi indeferido, ou apreciação das questões de mérito se a sentença for terminativa.

Não obstante a gravidade do vício, não se pode partilhar da opinião de que a sentença citra petita é necessariamente nula, pois, em determinados casos, é possível a oposição de embargos declaratórios para corrigir o erro, uma vez que o já citado artigo 897-A da CLT admite efeito modificativo da decisão nos casos de omissão e contradição no julgado.

O julgamento ultra e extra petita, por outro lado, é fonte de confusões e controvérsia. Até o momento, optou-se por não diferenciar rigorosamente a ultra e a extrapetição, tendo em vista que ambas têm em comum a característica de excederem os limites da lide. No próximo capítulo, quando serão analisadas as decisões do TST sobre o assunto, observar-se-á que a confusão entre os dois termos é corrente. Não obstante, vejase como os diferencia a doutrina.

Eduardo Arruda Alvim sustenta que "será ultra petita quando a sentença for além do pedido formulado, concedendo ou deixando de conceder expressamente mais do que tenha sido pedido. Já a sentença extra petita, como vimos, constituiu-se em julgar coisa diversa da que fora pedido"174. Vicente Greco Filho diz que "a sentença que julga além do pedido se diz ultra petita, a que julga fora do pedido se diz extra petita" ${ }^{175}$ e Alexandre de Paula afirma que

a sentença pode apresentar-se incompleta, por não enfrentar e resolver todos os pedidos formulados (citra petita); pode concluir selecionando coisa inteiramente fora dos pedidos (extra petita); e pode, além de dar deslinde às questões apresentadas, ir além e conceder mais do que foi pedido (ultra petita) ${ }^{176}$.

\footnotetext{
${ }^{174}$ ALVIM, Eduardo Arruda. Manual de direito processual civil. São Paulo: Revista dos Tribunais, 1998. p. 660-661. Grifos no original.

${ }^{175}$ GRECO FILHO, Vicente. Direito Processual Brasileiro. v. 2. São Paulo: Saraiva, 2000. p. 226. Grifos no original.

${ }^{176}$ PAULA, Alexandre de. Código de Processo Civil Anotado. v. 2. São Paulo: Revista dos Tribunais, 1986.
} 
A doutrina trabalhista segue a mesma linha de diferenciação: "se a sentença não se contiver nos contornos do litígio, indo além deles, diz-se que julgou ultra ou extra petita (além ou fora do pedido)", ensina Wagner D. Giglio ${ }^{177}$.

Aparentemente, não se vislumbra o problema dessa diferenciação, já que a doutrina está de acordo em que o julgamento extra petita é aquele fora do pedido e o ultra é o que vai além do pedido. A questão é que nem sempre distinguir o que está fora e o que vai além é uma tarefa fácil. Exemplos doutrinários como "o autor pede uma vaca e o juiz dá uma cabra" para ilustrar o primeiro caso e "o autor pede uma vaca e o juiz dá uma vaca premiada", para o segundo, são meramente didáticos, pois a realidade não se apresenta em branco e preto. Por isso a recorrente mistura dos dois conceitos e - como ser verá no próximo capítulo - a completa desconsideração da distinção.

Não obstante, como bem aponta Vallisney de Souza Oliveira,

\begin{abstract}
é importante estabelecer a diferença entre esses dois vícios de julgamento, considerando que uma espécie pode levar à redução do excedente, mas não há nulidade total do julgado, enquanto a outra, em razão de o juiz ter passado ao largo do pedido e julgado sobre o que não foi requerido, pode resultar na invalidade da sentença, não sendo permitido adequá-la à pretensão inicialmente formulada. Em outras palavras, somente haverá excesso a ser decotado em casos de sentença ultra petita $^{178}$.
\end{abstract}

Há que se reconhecer, contudo, que, dada a estrutura mais comum da reclamação trabalhista, dificilmente se verá uma sentença totalmente extra petita. Explica-se. Em geral, as ações trabalhistas que se referem a contratos de trabalho apresentam pedidos múltiplos - ainda que decorrentes da mesma relação material -, de modo que o mais provável é que a sentença trabalhista em que se vislumbre a extrapetição abranja também os pedidos formulados pelo autor. Nesse sentido, a sentença extra petita apenas poderá ser declarada nula se deixar de apreciar os pedidos formulados pelo autor e conceder algo completamente distinto, cabendo, a exemplo do que ocorre na ultrapetição, apenas o aparo do que foi concedido fora do pedido, se a pretensão do autor tiver sido satisfatoriamente apreciada pelo juiz.

No próximo capítulo, a análise das decisões do TST ajudará a esclarecer a distinção entre os dois conceitos e as suas consequências.

\footnotetext{
p. 597. Grifos no original.

${ }^{177}$ GIGLIO, Wagner D.; CORREAA, Cláudia Giglio Veltri. Direito Processual do Trabalho, p. 261. Grifos no original.

${ }^{178}$ OLIVEIRA, Vallisney de Souza. Nulidade da sentença e o princípio da congruência, p. 251.
} 


\subsection{Exceções ao Princípio da Congruência}

Tradicionalmente o princípio da congruência é tratado como a vinculação do juiz aos pedidos expressamente formulados pelo autor; contudo, como foi visto até o momento, tal conceituação não é exata, uma vez que a causa de pedir da petição inicial e os fatos trazidos aos autos pelo réu também delimitam a matéria que pode ser conhecida pelo juiz. Assim, a tendência neste trabalho é entender o princípio ora estudado no âmbito da ideia de adequação entre o que é pleiteado e o que pode ser concedido, rompendo com a necessidade de identidade absoluta.

A partir desse conceito, a violação ao princípio da congruência se daria apenas nos casos em que o juiz deixasse de examinar parcela das alegações das partes (julgamento citra petita), quando julgasse com base em fatos completamente estranhos aos autos ou ainda quando inferisse pedidos que não decorressem logicamente da causa de pedir. Não é este, contudo, o corte estabelecido para este subitem. As exceções ao princípio da congruência foram selecionadas a partir do estudo da doutrina processual civil e trabalhista que adota a ideia tradicional de princípio da congruência.

De acordo com Mario Helton Jorge ${ }^{179}$, é possível identificar duas situações que constituem exceções ao princípio da congruência, em que o juiz deixa de ter sua atividade vinculada aos pedidos da petição inicial: pedidos implícitos e matéria de ordem pública.

A abordagem desse autor é interessante na medida em que considera como exceção ao princípio da congruência, além da mais conhecida hipótese de pedido implícito, também as situações em que ao juiz é permitido atuar de ofício por se tratar de matéria de ordem pública. É possível que a omissão dessa hipótese nos estudos sobre o princípio da congruência deva-se a uma espécie de "naturalização" da natureza de ordem pública de certas matérias, como a incompetência absoluta ou os direitos indisponíveis. Contudo, a eleição de normas de ordem pública é uma questão inegavelmente política, que se liga diretamente ao grau de intervenção estatal nas relações privadas, dando maior ou menor efetividade ao princípio dispositivo. Assim, a publicização das normas que regulam as relações jurídicas tem impacto direto no princípio da congruência, permitindo que o juiz conheça ou não determinadas matérias de ofício.

Como já analisado no Capítulo 2, a maior parte das normas trabalhistas tem por característica principal o caráter público - escolha feita pelo Estado Brasileiro para garantir

\footnotetext{
179 JORGE, Mario Helton. A garantia de imparcialidade do órgão jurisdicional e as hipóteses de aparente parcialidade. Revista dos Tribunais, São Paulo, v. 95, n. 844, p. 56-68, jan. 2008.
} 
a efetividade do Direito Laboral -, de modo que não pode haver dúvida sobre a pertinência do conhecimento de ofício, pelo juiz, de pedidos não formulados pelo autor de reclamação trabalhista, quando se tratar de direitos indisponíveis decorrentes da relação material descrita na causa de pedir.

Considerando que a questão do caráter na norma trabalhista já foi devidamente estudada, não há necessidade de se ater mais a essa primeira situação. Isso porque, como se sabe, se as normas que regulam matéria de ordem pública têm o condão de diminuir ou mitigar a aplicação do princípio dispositivo, também se deve admitir que possam flexibilizar o princípio da proibição do julgamento além do pedido, que nada mais é do que uma garantia do já citado princípio dispositivo. Passar-se-á, então, à análise detalhada dos casos de pedidos implícitos.

\subsubsection{Pedidos Implícitos?}

Trata-se de assunto fascinante, que merece, antes de tudo, um estudo terminológico. Implícito, de acordo com o dicionário Houaiss ${ }^{180}$, é algo "contido numa proposição, mas não expresso formalmente; não manifestamente declarado; subentendido, tácito”. Seus antônimos são explícito, expresso.

Ora, reza o artigo 282 do CPC, como já visto, que a petição inicial indicará os fatos que constituem a causa de pedir e o pedido. "Indicação", nesse contexto, tem o significado de "explicitação". Nesse sentido é que o artigo 128 limita a sentença à matéria suscitada e o artigo 460, à matéria pedida, e a regra do artigo 293 dispõe sobre a interpretação restritiva do pedido. Desse ponto de vista, o pedido, assim considerado para fins processuais, deve estar absolutamente expresso na petição inicial, sob a pena de ser considerado inexistente.

Na sistemática da proibição dos julgamentos extra e ultra petita, é um paradoxo falar em pedido implícito. Nesse sentido manifestou-se Cândido Rangel Dinamarco:

\footnotetext{
Conceitualmente não há lugar para a existência de pedidos implícitos. Simplesmente a lei e o sistema dispensam o pedido em algumas hipóteses, investindo o juiz do poder de pronunciar-se sobre juros, correção monetária, astreintes etc., ainda quando não hajam sido pedidos pelo demandante. Mais que exceções à regra da interpretação estrita, são ressalvas à proibição de conceder tutela extrapolante ao pedido feito (arts. 128 e 460). Todas elas contam com bom apoio legitimador da tendência universal a desformalizar o processo e da consciência da necessidade de promover a efetividade da tutela jurisdicional e do
}

\footnotetext{
${ }^{180}$ HOUAISS, Antônio; VILLAR, Mauro de Salles. Dicionário Houaiss da Língua Portuguesa. CD-ROM.
} 
acesso à Justiça (particularmente as exceções relacionadas com as obrigações de fazer ou não-fazer); mas falar em pedido implícito é valer-se arbitrariamente de uma desnecessária ficção legal, porque basta reconhecer que todos esses são casos em que o pedido é dispensável, não havendo por que fingir que ele haja sido deduzido ${ }^{181}$.

Contudo, deve ser feita uma ressalva histórica à noção de pedido implícito: o Direito Moderno é tributário não apenas de uma tradição romana cujo Direito Processual exigia o uso exato de palavras sacramentais ${ }^{182}$ sob pena de perda do direito, mas também de uma tradição mais recente positivista, cuja ideia de atividade judicial limitava-se à mera subsunção do fato à norma e cuja regra de interpretação era a literal. Apenas diante desse quadro é que se pode dizer que o processo moderno admitiu pedidos implícitos. Porém, o que se verificou foi apenas um desenvolvimento da hermenêutica, passando a regra a ser a interpretação sistemática da norma e, por via de consequência, a interpretação do pedido dentro do contexto narrado na inicial. Essa nova regra, contudo, não viola a norma que prevê a interpretação restritiva. Nas palavras de Carlos Eduardo Stefen Elias, "a interpretação restritiva não se confunde com a interpretação literal (...) o uso linguístico literal do termo ou da oração pode não corresponder ao significado jurídico, o que torna necessária referência ao contexto (legal e fático) no qual o termo se insere"183. Nota-se que esse desenvolvimento da ciência da interpretação das normas jurídicas está em perfeita consonância com a teoria da instrumentalidade das formas processuais, rejeitando um formalismo extremado em nome da efetividade do processo. Mas disso não decorre, logicamente, que a interpretação do pedido tenha passado de restritiva para extensiva.

Assim, concorda-se com Cândido Rangel Dinamarco, no sentido de que é um erro denominar implícitos os pedidos que a lei ou a jurisprudência desobrigaram o autor de formular, como é o caso de pedidos decorrentes de normas de ordem pública! Se de fato fossem implícitos e a justificativa da sua concessão fosse unicamente a decorrência lógica do pedido, restaria por terra a regra da interpretação restritiva do pedido, não havendo necessidade de lei ou construção jurisprudencial permitindo o julgamento além do pedido expresso, bastando a mera atividade interpretativa do juiz.

${ }^{181}$ DINAMARCO, Cândido Rangel. Instituições de Direito Processual Civil. v. 3. São Paulo: Malheiros, 2002. p. 137.

${ }^{182}$ Na doutrina do Direito Romano, é citado o caso de um litigante que perdeu a ação porque, no processo, em vez de empregar a palavra "árvore", usou a palavra "videira", o que contrariava a lei, muito embora se tratasse, no caso concreto, de um litígio sobre videiras, conforme The institutes of Gaius, Zulueta, Oxford, 1946, I-II (sic) apud CRETELLA JUNIOR, José. Curso de Direito Romano. Rio de Janeiro: Forense, 1999.

${ }^{183}$ ELIAS, Carlos Eduardo Stefen. As reformas processuais e o princípio da congruência entre sentença e o pedido. Revista de Processo, São Paulo, v. 33, n. 58, p. 38-64, abr. 2008. 
Rejeitada a tese de pedidos implícitos, há que se debruçar sobre as exceções ao princípio da congruência, extraindo delas seu fundamento político e social, de modo a concluir se se trata de exceções justificadas ou arbitrariedades do legislador.

\subsubsection{Exceções Legais e Jurisprudenciais ao Princípio da Congruência}

As exceções ora expostas são pacíficas no âmbito da doutrina processual, tendo-se optado por manter casos previstos na doutrina processual civilista que sejam aplicáveis ao Processo do Trabalho, para melhor compreensão dos seus fundamentos. Nota-se, ainda, que algumas exceções originam-se em entendimentos jurisprudenciais, mas não se confundem com o estudo que será feito no Capítulo 4, pois são exceções já consolidadas por súmulas ou orientações jurisprudenciais dos Tribunais Superiores e que não apresentam polêmica entre os estudiosos.

\subsubsection{Medidas Cautelares}

A relativização do princípio da congruência pode ser levada a cabo de diversas maneiras. Exemplo notório da desvinculação da atividade judicial do pedido da parte é a fungibilidade das demandas, mais especificamente das medidas cautelares, ou seja, a possibilidade de substituição, de ofício, de medidas cautelares típicas entre elas ou por medida cautelar atípica, quando satisfeitos certos pressupostos. Trata-se de tema tradicional na doutrina brasileira, mas que ainda não está pacificado.

Antes do advento da Lei $n^{\circ} 8.952$ de 13 de dezembro de 1994, a doutrina predominante, além de restringir o cabimento da fungibilidade das medidas cautelares a determinadas hipóteses, não entendia possível que a substituição de medidas se fizesse sem o requerimento do autor ou do réu. Apenas com a reforma do artigo 805 do CPC - "a medida cautelar poderá ser substituída, de ofício ou a requerimento de qualquer das partes, pela prestação de caução ou de garantia menos gravosa para o requerido, sempre que adequada e suficiente para evitar lesão ou repará-la integralmente" - é que ficaram pacificadas a doutrina e a jurisprudência acerca da desvinculação, de ofício, da medida cautelar pleiteada em relação à medida cautelar concedida ${ }^{184}$. Nota-se, ainda, que a

\footnotetext{
184 Persiste, é verdade, celeuma no tocante à possibilidade de fungibilidade quando presentes os requisitos de
} 
modificação legislativa foi além da permissão de troca de uma medida por outra, deixando a cargo do julgador a análise de adequação e suficiência da medida a ser adotada.

Eduardo Talamini aponta que, embora a desvinculação da decisão judicial do pleito de medida cautelar seja, costumeiramente, justificada pelo caráter de ordem pública desse tipo de provimento, na realidade a fungibilidade das medidas cautelares está mais ligada à racionalização e operatividade da atividade judicial, pois o que interessa ao autor é a proteção do bem ameaçado (pedido mediato), não o modus operandi (pedido imediato). Nesse sentido, a exigência de congruência poderia levar à frustração do direito do autor. Assim explica o citado autor:

em certo sentido, a não aplicação do princípio da congruência ao pedido imediato destina-se a intensificar a exatidão da correspondência entre tutela (o resultado da atuação jurisdicional) e o pedido mediato. (...) A congruência formal cede espaço à congruência material ${ }^{185}$.

Conclui-se, portanto, que a fungibilidade das medidas cautelares, enquanto exceção ao princípio da congruência, liga-se não somente ao princípio da economia processual, mas também - e principalmente - à efetividade do processo.

\subsubsection{Prestações Vencidas no Curso do Processo}

Em seu artigo 290, o CPC dispõe que

quando a obrigação consistir em prestações periódicas, considerar-se-ão elas incluídas no pedido, independentemente de declaração expressa do autor; se o devedor, no curso do processo, deixar de pagá-las ou de consigná-las, a sentença as incluirá na condenação, enquanto durar a obrigação.

Trata-se, portanto, de verdadeira exceção ao princípio da congruência, permitida pelo próprio Código. Fossem as prestações vincendas e vencidas no curso do processo decorrência lógica do pedido de cumprimento da obrigação, não haveria necessidade de o legislador estabelecer a regra do artigo 290.

Fez bem o CPC ao permitir o conhecimento de ofício do juiz das prestações que vencerem no curso do processo: em primeiro lugar, evita-se propositura de nova ação visando ao recebimento destes valores; em segundo lugar, evita-se que o réu aproveite-se

medida cautelar típica. Contudo, para o fim deste trabalho, importa a parte inicial do artigo 805 do Código de Processo Civil, que passou a permitir a conversão de ofício.

${ }^{185}$ TALAMINI, Eduardo. Tutela relativa aos deveres de fazer e não fazer. São Paulo: Revista dos Tribunais, 2001. p. 282. 
da demora do processo em benefício próprio; e, por fim, trata-se de medida de efetividade da tutela jurisdicional, já que o autor, ao propor a ação, pretende o cumprimento completo da obrigação contraída com o réu e não apenas parte dela. No Processo do Trabalho, embora o mais comum seja a propositura de ações após o término contratual, ainda é possível encontrar situações em que há o vencimento de prestações no curso do processo, como o caso de pedido de reconhecimento de rescisão indireta. Nesse sentido, a possibilidade de inclusão das parcelas vencidas na condenação tem grande relevância, tendo em vista o caráter alimentar do salário do empregado.

\subsubsection{Fato Superveniente}

Na realidade, a regra do artigo 290 do CPC nada mais é do que espécie da regra geral prevista no artigo 462 do mesmo diploma, que permite ao juiz tomar conhecimento de fato constitutivo, modificativo ou extintivo do direito que possa, depois da propositura da ação, influir na decisão final. Por certo, tal fato deve ter relação com os expostos na petição inicial. Contudo, essa ressalva não desnatura o caráter transgressor do princípio da congruência que este artigo carrega, tendo em vista a posição da doutrina tradicional sobre o assunto. Levando-se em consideração os princípios da segurança jurídica, estabilização da demanda e contraditório - basilares da proibição da sentença ultralextra petita - não parece ser sustentável admitir novos fatos.

Porém, agiu de modo correto o legislador ao permitir a inserção de fatos novos relevantes: ainda que flexibilize o princípio da congruência, evita que o juiz gaste tempo decidindo sobre questões superadas, homenageando o princípio da economia processual. Assim é o caso de empregado que requer o reconhecimento de rescisão indireta e, no curso do processo, é dispensado sem justa causa: não será mais necessário que o juiz se debruce sobre a justa causa do empregador para determinar o pagamento de aviso prévio, por exemplo.

Considerando-se, portanto, o caráter prático desta exceção - evitar o pronunciamento sobre fatos não mais existentes ou modificados - há que se estender o raciocínio para permitir que o juiz, tendo conhecimento em instrução de fatos que sustentem ou rejeitem o direito do autor, mas que não tenham sido alegados expressamente pelas partes, possa deles conhecer e utilizá-los como fundamento de sua decisão, ainda que não se trate, exatamente, de fatos supervenientes. 


\subsubsection{Correção Monetária e Juros}

O artigo 293 do CPC determina que o pedido seja interpretado restritivamente, “compreendendo-se, entretanto, no principal os juros legais". Ora, trata-se, evidentemente, de exceção expressa ao princípio da congruência que, porém, não se enquadra na hipótese de norma de ordem pública.

Os juros legais podem ser de mora ou compensatórios e decorrem da relação material, constituindo acessórios da obrigação principal. Contudo, não se pode dizer, sem incorrer no risco de perverter o princípio da congruência, que a justificativa da exceção relaciona-se a essa acessoriedade dos juros. Isso porque, aceitando-se tal justificativa, haver-se-ia que considerar a possibilidade de se reconhecer de ofício toda obrigação acessória decorrente da obrigação principal objeto do pedido do autor, transformando-se a regra prevista no artigo 59 do CC de 1916 - "salvo disposição especial em contrário, a coisa acessória segue a principal" -, inexistente no atual CC como regra geral, mas considerada ainda presente ${ }^{186}$, em regra de interpretação processual. Tal justificativa levaria à conclusão absurda de que, caso o autor quisesse abrir mão de qualquer obrigação acessória (com exceção dos juros, claro), deveria formular pedido para que não fosse reconhecida.

Os juros são destinados à compensação do credor pela perda do bem por determinado período. A demora na prestação jurisdicional, infeliz característica do Judiciário brasileiro, é fator que agrava a privação do bem devido ao autor (no caso de sentença procedente), servindo de incentivo ao réu para que permaneça inerte. Assim, pode-se dizer que a regra do artigo 293, parte final, tem dupla função: compensar o autor vencedor pela demora na prestação jurisdicional e contribuir, ainda que indiretamente, para a celeridade processual, pois o réu pode ter interesse em não pagar juros.

No tocante à correção monetária, não é correto o que parte da doutrina sustenta, afirmando ser tal exceção ao princípio da congruência uma construção jurisprudencial. Tal suposição apenas perpetua a errônea ideia de pedido implícito. A aplicação de correção monetária às decisões judiciais está prevista no artigo $1^{\circ}$ da Lei $n^{\circ} 6.899$ de 8 de abril de 1981. Trata-se, portanto, de dispensa de formulação de pedido de correção monetária, por

186 A regra do artigo 59, portanto, não está reproduzida no novo Código Civil por ser desnecessária. Ver SIMÃO, José Fernando. O Acessório Segue a Sorte do Principal no Sistema do Novo Código Civil? Disponível em: <http://www.professorsimao.com.br/artigos_simao_o_acessorio.htm>. Acesso em: $17 \mathrm{dez}$. 2010. 
haver previsão legal cogente. Tal lei, nota-se, foi editada nos anos de 1980, época conhecida pelos altíssimos índices de inflação, que corroíam o valor da moeda. De modo a preservar o valor aquisitivo de uma determinada soma de dinheiro quando do início de uma ação, o legislador entendeu por bem editar norma obrigando a correção monetária de qualquer débito. E mais, ao contrário do que ocorre com os juros, da leitura da referida lei infere-se que não é lícito às partes afastar a incidência da correção monetária. Trata-se de norma de ordem pública.

\subsubsection{Custas Processuais e Tutela das Obrigações de Fazer/Não Fazer}

Na esteira da natureza cogente da correção monetária, passar-se-á ao estudo das custas processuais e tutela das obrigações de fazer/não fazer como exceção ao princípio da congruência. Ensina Mario Helton Jorge ${ }^{187}$ que o pedido, assim entendida a pretensão do autor, refere-se à relação substancial sobre a qual se debruça o processo, e decorre, portanto, da causa de pedir. Custas processuais e a tutela prevista no artigo 461 do CPC, pelo contrário, decorrem da relação processual, não podem ser objeto de ação autônoma e não são deduzíveis da causa de pedir. São, na realidade, consequências previstas no Código de Processo Civil para o evento da sucumbência ou como instrumento de efetividade da decisão processual. Assim como a correção monetária, o conhecimento de ofício das matérias acima expostas é fundamentado na publicidade da natureza da norma, não em uma eventual "decorrência lógica do pedido".

\subsubsection{Multa por Litigância de Má-Fé Processual}

A multa por litigância de má-fé, decerto, não decorre da relação substancial, mas sim de condutas impróprias no curso do processo e a ele relacionadas. Cabe, antes de tudo, fazer uma distinção entre duas categorias de má-fé processual: a prevista no artigo 17 do CPC (má-fé de uma das partes em prejuízo da outra) e a prevista no artigo 129 do mesmo diploma (colusão das partes). Assim como ocorre com as custas processuais e os honorários advocatícios, a possibilidade de decretação de multa por litigância de má-fé é norma de ordem pública, destinada a resguardar o interesse superior do Estado (interesse em preservar os institutos e valores do Judiciário) em detrimento de interesses mesquinhos

\footnotetext{
187 JORGE, Mario Helton. A garantia de imparcialidade do órgão jurisdicional e as hipóteses de aparente parcialidade, p. 64.
} 
- e, por vezes, ilícitos - das partes. Contudo, embora ambas possam ser conhecidas de ofício pelo juiz, autorizado a decretar multa, relativizam o princípio da congruência em níveis muito diferentes.

A hipótese do artigo 18 do CPC -

O juiz ou tribunal, de ofício ou a requerimento, condenará o litigante de má-fé a pagar multa não excedente a um por cento sobre o valor da causa e a indenizar a parte contrária dos prejuízos que esta sofreu, mais os honorários advocatícios e todas as despesas que efetuou.

- tem por objetivo coibir ou até mesmo consertar a conduta ilícita de uma das partes, visando à continuidade normal do processo. Pode-se considerar que a litigância de má-fé é caso de fato superveniente, com capacidade de influir no processo, estando o seu conhecimento de ofício autorizado, também pelo artigo 462 do CPC. Hoje, em virtude da modificação do artigo 18 feita pela Lei $n^{\circ} 8.952 / 94$, que foi modificada pela Lei $n^{\circ}$ 9.668/98, a identificação da litigância de má-fé com o fato superveniente é inócua. Contudo, não se pode esquecer que até a primeira modificação, o entendimento majoritário na doutrina e na jurisprudência era no sentido de que a litigância de má-fé deveria ser suscitada pela parte a ser beneficiada pela multa, fechando-se os olhos para o interesse eminentemente público que se visa proteger com a punição desse tipo de conduta.

Já o artigo 129 do CPC - "Convencendo-se, pelas circunstâncias da causa, de que autor e réu se serviram do processo para praticar ato simulado ou conseguir fim proibido por lei, o juiz proferirá sentença que obste aos objetivos das partes” - visa obstar conluio das partes que se utilizam do processo para alcançar fim ilícito. Neste caso, atuação do juiz não será destinada a, punindo a litigância de má-fé-, permitir a continuidade normal do processo. Ao contrário da hipótese do parágrafo anterior, não haverá sequer a análise do pedido das partes, devendo o juiz proferir sentença que impeça a concretização dos intuitos ilegais e antiéticos das partes. Ora, por certo, tal sentença não guardará correlação com o pedido formulado pelo autor, mas não padecerá de qualquer nulidade, posto que a exceção ao princípio da congruência é expressamente permitida por norma processual, além de estar amparada nos mais nobres valores do Direito Processual Civil ${ }^{188}$.

${ }^{188}$ Em artigo intitulado $O$ julgador diante da inércia do demandante em relação ao pedido, a Juíza do
Trabalho Mariane Khayat defende a aplicação do disposto no artigo 129 do Código de Processo Civil no caso
de as partes fazerem mau uso do processo, embora não haja colusão entre elas. Cita o seguinte exemplo:
Empresa X paralisa as atividades, mas não rescinde os contratos de trabalho. Os empregados apresentam
reclamação trabalhista pedindo os salários vencidos e vincendos. Em defesa, a empresa alega rescisão
contratual por justa causa, já que os empregados estão trabalhando em outra empresa. A autora diz que há um
impasse, pois é socialmente nocivo deferir os salários ad eternum, já que não há prestação de serviços, mas
também não pode rescindir o contrato por justa causa, pois esta é inexistente. A melhor solução, de acordo
com a juíza, seria a rescisão indireta dos contratos de trabalho. Contudo, tal decisão acarretaria em julgamento
extra petita. Assim, sugere o uso do poder previsto no artigo 129 do Código de Processo Civil, em nome do 
Como se vê, enquanto o conhecimento de ofício da litigância de má-fé do artigo 17 implica tão somente a concessão de multa não requerida pela parte prejudicada, permanecendo o dever de o juiz ater-se às questões propostas pelas partes em inicial e na defesa quando for proferir a sentença, o conhecimento da litigância de má-fé do artigo 129 resulta em uma total desvinculação da sentença dos pedidos formulados pelo autor!

\subsubsection{Anotação em Carteira de Trabalho e Previdência Social e Declaração de Vínculo Empregatício}

Prevê o artigo 13 da CLT que a Carteira de Trabalho e Previdência Social (CTPS) é obrigatória para o exercício de qualquer emprego, devendo o empregador, nos termos do artigo 27-A do mesmo diploma, proceder à anotação do contrato neste documento. Trata-se de evidente relação de forma e conteúdo: o conteúdo do contrato de emprego é o trabalho subordinado, remunerado, oneroso e pessoal, formalizado pela anotação em carteira. Devese observar, ainda, que a inexistência de anotação do referido contrato não importa em inexistência do contrato, nem mesmo em sua nulidade, podendo o vínculo ser reconhecido administrativamente ou judicialmente, por uma decisão de natureza declaratória, ou seja, ex tunc.

Jorge Luiz Souto Maior ${ }^{189}$ aponta o problema que surge quando da apreciação de pedido formulado em petição inicial em que se requer tão somente a anotação em CTPS, sem que haja o pedido de reconhecimento de vínculo empregatício. O autor colaciona ao artigo decisões judiciais que consideraram inepta a petição inicial assim formulada, uma delas, inclusive, fazendo alusão à potencial extrapetição de decisão que conhecesse do pedido de reconhecimento de vínculo empregatício. Trata-se de rigor exagerado, incompatível com o espírito da Justiça do Trabalho, caracterizado pela informalidade e celeridade.

Embora não se partilhe da ideia defendida - de que o pedido de reconhecimento de vínculo está implícito no de anotação em CTPS - a conclusão não poderia ser mais acertada: "o pedido expresso da declaração da relação de emprego não é requisito da petição inicial trabalhista"190. Há que se ressaltar, contudo, que o artigo em comento foi elaborado em 2000, antes da ampliação da competência da Justiça do Trabalho, pela

interesse público e do mau uso do processo. Ver KHAYAT, Mariane. O julgador diante da inércia do demandante em relação ao pedido. LTr : Suplemento Trabalhista, São Paulo, v. 26, n. 52, p. 273-274, 1990.

189 SOUTO MAIOR, Jorge Luiz. Inépcia da inicial - pedido de declaração de vínculo empregatício. In: (Org.). Temas de processo do trabalho, p. 28-29.

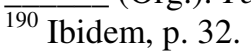


Emenda Constitucional $\mathrm{n}^{\circ} 45$ de 30 de dezembro de 2004, quando essa justiça especializada passou a poder julgar litígios decorrentes não somente da relação de emprego, mas de toda e qualquer relação de trabalho. Deste modo, o reconhecimento de relação de emprego não é mais conditio sine qua non para a determinação da competência da Justiça do Trabalho. Assim, a dispensa de formulação de pedido de reconhecimento de vínculo empregatício não se justifica por um elemento externo - o órgão julgador -, mas sim pela sua natureza pública e imperativa: uma vez que o juiz vê demonstrados e provados os requisitos previstos no artigo $3^{\circ}$ da CLT, é sua obrigação reconhecer o vínculo empregatício e determinar a anotação em CTPS.

\subsubsection{Indenização do Empregado Estável}

Talvez o caso mais "famoso" de atuação de ofício em questões de Direito Material seja a possibilidade de conversão de pedido de reintegração de empregado estável em indenização.

A estabilidade no emprego, de acordo com Amauri Mascaro Nascimento, é "o direito do empregado de manter o emprego mesmo contra a vontade do empregador"191, justificado, no entendimento deste autor, por um "direito ao emprego", fundamentado na teoria francesa da propriedade do emprego, e no princípio da continuidade do contrato de trabalho, posto que o salário tem função alimentar, indispensável para a subsistência do empregado e de sua família. Atualmente, a lei brasileira apenas prevê hipóteses de estabilidade provisória, sendo que os principais casos são: estabilidade da empregada grávida, do empregado acidentado, dos empregados eleitos para cargos sindicais ou na Comissão Interna de Prevenção de Acidentes (CIPA). O objetivo de tais estabilidades é, por um lado, a preservação do emprego de pessoas circunstancialmente menos atrativas ao mercado de trabalho, e, por outro, a inibição de condutas persecutórias aos empregados cipeiros ou sindicalistas.

Como bem prevê o artigo 496 da CLT, há casos, contudo, em que é desaconselhável a reintegração do empregado, em razão da natureza do conflito, facultando-se, ao tribunal ou juízo, a conversão da reintegração em indenização. Este artigo é fonte de grandes polêmicas: a primeira delas consiste em saber se é permitido ao empregado ingressar diretamente com pedido de indenização, alegando a referida

${ }^{191}$ NASCIMENTO, Amauri Mascaro. Curso de direito do trabalho. São Paulo: Saraiva, 2006. p. 775. 
incompatibilidade. Amauri Mascaro Nascimento sustenta que "a estabilidade não oferece vantagens de natureza patrimonial, já que apenas dá ao trabalhador um direito: o emprego"192, logo, teria o empregado apenas direito a formular a pretensão de ser reintegrado, cabendo ao Judiciário a apreciação da conveniência da reintegração ou não. Ressalvada opinião em contrário, tal posicionamento revela típico caso de flexibilização do princípio da congruência: o empregado ingressa com pedido de reintegração no emprego e o juiz, apreciando as circunstâncias do caso, condena a empresa ao pagamento da indenização prevista no artigo 497 da CLT. Trata-se de evidente desconexão entre o pedido e o provimento, autorizada por lei e confirmada jurisprudencialmente, uma vez que a súmula 396 do TST afasta a nulidade de julgamento neste sentido.

\subsubsection{Contribuições Previdenciárias}

A Emenda Constitucional $n^{\circ} 45$ de 30 de dezembro de 2004 veio reforçar o estipulado pela Lei $\mathrm{n}^{\mathrm{o}} 10.035$ de 25 de outubro de 2000 ao garantir à Justiça do Trabalho a competência para a execução, ex officios das contribuições previdenciárias decorrentes das sentenças por ela proferidas. Não obstante a lei disponha sobre "execução" de ofício, deve prevalecer o entendimento de Wagner D. Giglio de que a intenção da lei é permitir que "fossem incluídas nas decisões condenatórias as contribuições previdenciárias, mesmo não havendo pedido nesse sentido" $" 193$.

Tal posição justifica-se por dois motivos. Em primeiro lugar, a incidência de contribuição previdenciária independe da vontade das partes, sendo norma de ordem pública aquela que determina o pagamento de tal contribuição sobre as verbas de natureza salarial $^{194}$; ademais, pela questionável lógica atual, o reconhecimento de vínculo empregatício na Justiça do Trabalho não vincula a Previdência Social para fins de contagem de tempo de serviço, de modo que, ao incluir o recolhimento previdenciário na sentença condenatória, o magistrado trabalhista garante ao empregado tutela mais completa de seus direitos, incluindo os que são reflexos da relação de emprego ${ }^{195}$. Em segundo lugar, é uma questão de efetividade da norma: de que serve permitir ao juiz executar de

\footnotetext{
192 NASCIMENTO, Amauri Mascaro. Curso de direito do trabalho, p. 781.

${ }^{193}$ GIGLIO, Wagner D.; CORRÊA, Cláudia Giglio Veltri. Direito Processual do Trabalho, p. 262.

${ }^{194}$ Artigo 20 c/c artigo 28 da Lei no 8.212 de 24 de julho de 1991.

195 De acordo com o relatório "A justiça do trabalho em números", do CNJ, entre 2004 e 2008, a Justiça do Trabalho arrecadou mais de $\mathrm{R} \$ 950.000 .000,00$ (novecentos e cinquenta milhões de reais) a título de contribuições previdenciárias.
} 
ofício as contribuições, sem lhe dar o poder de incluí-las na condenação, mesmo sem que haja pedido do autor? Nas palavras do poeta, é exatamente o caso de permitir a navegação, mas proibir fazer barcos...

\subsubsection{Multa do Artigo 467 da CLT}

Wagner D. Giglio aponta como outro exemplo de flexibilização do princípio ora estudado a aplicação do previsto no artigo 467 da CLT: "a jurisprudência autoriza a condenação, mesmo sem pedido na inicial, no pagamento do acréscimo de 50\% sobre as verbas rescisórias, incontroversamente devidas e não satisfeitas na data do comparecimento da reclamada à audiência" ${ }^{, 196}$.

A aplicação dessa multa nada mais é do que fato superveniente à propositura do processo. Explica-se: o "fato gerador" da multa é a falta de pagamento das verbas incontroversas em audiência, motivo pelo qual há que se aguardar tal evento para que a multa seja devida. Ou seja, quando da elaboração da petição inicial, não tem o empregado, ainda, pretensão de exigir o pagamento da multa, de modo que é justificável e lógica a posição de Wagner D. Giglio ao defender que o magistrado deve julgar além do pedido nestes casos.

Tentou-se, neste capítulo, conceituar e delimitar o princípio da congruência e reunir suas principais exceções, dando-se ênfase aos casos mais explícitos. Decerto, apenas uma análise jurisprudencial mais aprofundada, que será objeto do próximo capítulo, poderá oferecer a real dimensão da relativização da vinculação da sentença ao pedido no sistema processual trabalhista.

Contudo, o reconhecimento de que, em determinado casos, o Estado é incapaz de, pelas regras processuais que delimitam os limites da lide, resolver satisfatoriamente certos litígios, é o primeiro passo para o questionamento de um sistema rígido de vinculação em face dos valores que informam o Direito Processual brasileiro.

${ }^{196}$ GIGLIO, Wagner D.; CORRÊA, Cláudia Giglio Veltri. Direito Processual do Trabalho, p. 262. 


\section{APLICAÇÃO DO PRINCÍPIO DA CONGRUÊNCIA NO TRIBUNAL SUPERIOR DO TRABALHO: UMA ANÁLISE JURISPRUDENCIAL}

\subsection{Metodologia}

A análise jurisprudencial foi feita mediante pesquisa na Internet, observando-se os seguintes parâmetros:

1. Escolha das decisões do TST: a busca de jurisprudência sobre o tema ora pesquisado no âmbito do TST se faz pertinente tendo em vista a competência desse tribunal para conhecer Recurso de Revista contra decisão proferida com violação literal de disposição de lei federal. Recursos que versem sobre proferimento de sentença ultra ou extra petita devem, em geral, alegar violação aos artigos 128 e 460 do CPC. Note-se, contudo, que tal pesquisa restringiu-se às decisões proferidas pela Seção Especializada em Dissídios Individuais I (SDI-1), que tem por função uniformizar as decisões divergentes das Turmas, e pela Seção Especializada em Dissídios Individuais II (SDI-2), que conhece originariamente das ações rescisórias propostas contra as suas decisões, as da Subseção I e as das Turmas do Tribunal ${ }^{197}$. Ademais, a pesquisa jurisprudencial nos tribunais de segunda instância mostrou-se dificultada pela inexistência de mecanismos de busca no sítio de todos os Tribunais Regionais do Trabalho, o que levaria à necessidade de um corte geográfico aleatório. Por fim, a posição hierárquica do TST na ordem trabalhista confere maior abrangência e segurança às suas decisões, favorecendo uma pesquisa com o escopo de analisar o tratamento jurisprudencial dado a determinada questão;

${ }^{197}$ Artigo 894 da CLT c/c com artigo $3^{\circ}$ da Lei 7.701 de 21 de dezembro de 1988. 
2. Palavras-chave de busca: a busca no sítio do TST foi feita mediante a utilização dos termos ultra petita e extra petita, por sua precisão e recorrência na doutrina e na jurisprudência;

3. Período analisado: a presente pesquisa tem por objetivo descobrir o tratamento dado ao princípio da congruência pelo TST, permitindo que, a partir de então, possam ser pensadas mudanças de comportamento do operador do Direito e, eventualmente, modificações legislativas. As diversas reformas processuais levadas a cabo desde a criação da Justiça do Trabalho revelam constante renovação e reavaliação da política processual e judiciária. Assim, optou-se por limitar a presente pesquisa às decisões proferidas a partir da promulgação da Emenda Constitucional n 45 de 30 de dezembro de 2004, que promoveu a chamada "Reforma do Judiciário", estabelecendo novos padrões de comportamento para o Poder Judiciário em geral, com profundas mudanças na estrutura da Justiça do Trabalho; e

4. Fichamento das decisões: uma vez selecionados os acórdãos, procedeu-se ao fichamento das decisões (conforme modelo do Anexo 1), cujo objetivo era identificar os seguintes pontos: (i) assunto de direito material ou processual sobre o qual teria sido proferida decisão ultra ou extra petita; (ii) reconhecimento da ausência de pedido expresso, suas consequências e justificativas; e (iii) reconhecimento da ausência de causa de pedir, suas consequências e justificativas.

\subsection{Descrição dos Dados Colhidos e Gráficos}

Neste item, serão apresentados a descrição dos dados colhidos e os gráficos a eles relacionados, deixando ao próximo item a discussão das questões mais relevantes identificadas. A fim de facilitar a leitura, os aspectos que serão aprofundados foram marcados em negrito neste item.

A pesquisa, realizada no mês de junho de 2010, nos termos acima descritos, retornou 1.501 decisões, das quais foram selecionadas 149 (Anexo 2). Tal seleção levou em consideração (i) a existência de julgamento de mérito sobre a alegação de julgamento fora dos limites da lide e (ii) o limite anual de 10 decisões para cada termo - ultra petita e extra petita - no âmbito da SDI-1 e de 5 para cada termo no âmbito da SDI-2. Em alguns casos, não foi possível atingir o número máximo de decisões, em razão da escassez de 
acórdãos que versassem sobre o mérito. Assim, de acordo com o termo utilizado, tem-se o levantamento do seguinte número de decisões em cada SDI do TST:

Gráfico 1 - Decisões da SDI - 1: Decisões Ultra e Extra Petita

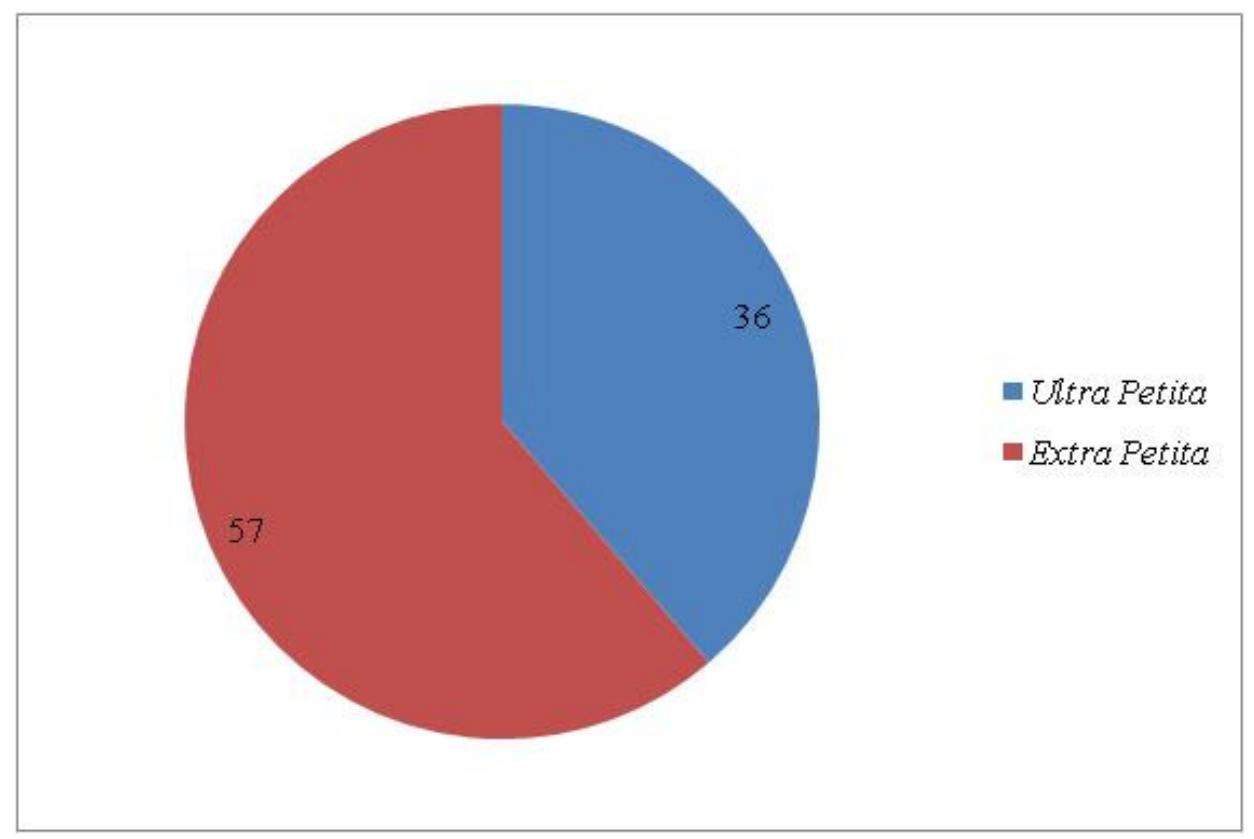

Gráfico 2 - Decisões da SDI - 2: Decisões Ultra e Extra Petita

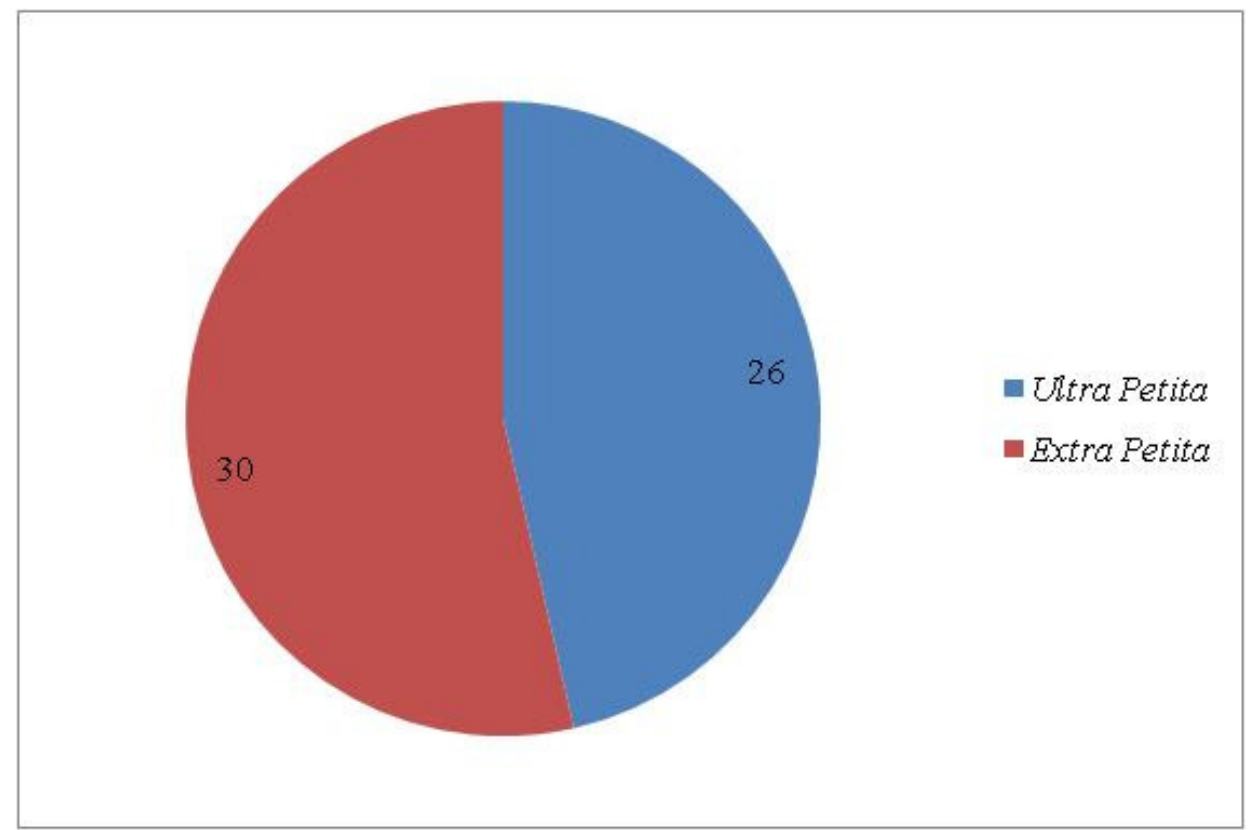


É marcante o fato de que a pesquisa tanto no âmbito da SDI-1 quanto no da SDI2 retornou mais decisões de mérito para o termo extra petita do que para o termo ultra petita. Ressalta-se, no entanto, que o critério para categorização das decisões foi baseado unicamente no retorno das pesquisas, sem que se tenha atentado para o conteúdo dos acórdãos. De fato, a análise dos acórdãos revela que tal diferença não reflete predominância de um tipo de violação sobre outro, mas sim confusão acerca dos conceitos de ultra e extrapetição, com o uso indiscriminado de um ou do outro, por vezes utilizados como sinônimos. Assim, é possível haver decisões apresentadas como ultra petita, mas que sejam extra petita e vice-versa. Tal "problema", entretanto, não deve ser identificado como uma falha da pesquisa, mas sim como um reflexo do entendimento do próprio tribunal acerca de tais termos.

No tocante ao assunto discutido, 134 decisões versaram sobre questões de Direito Material, enquanto apenas 15 discutiram temas de Direito Processual, conforme os gráficos:

Gráfico 3 - Assunto: Direito Material x Direito Processual

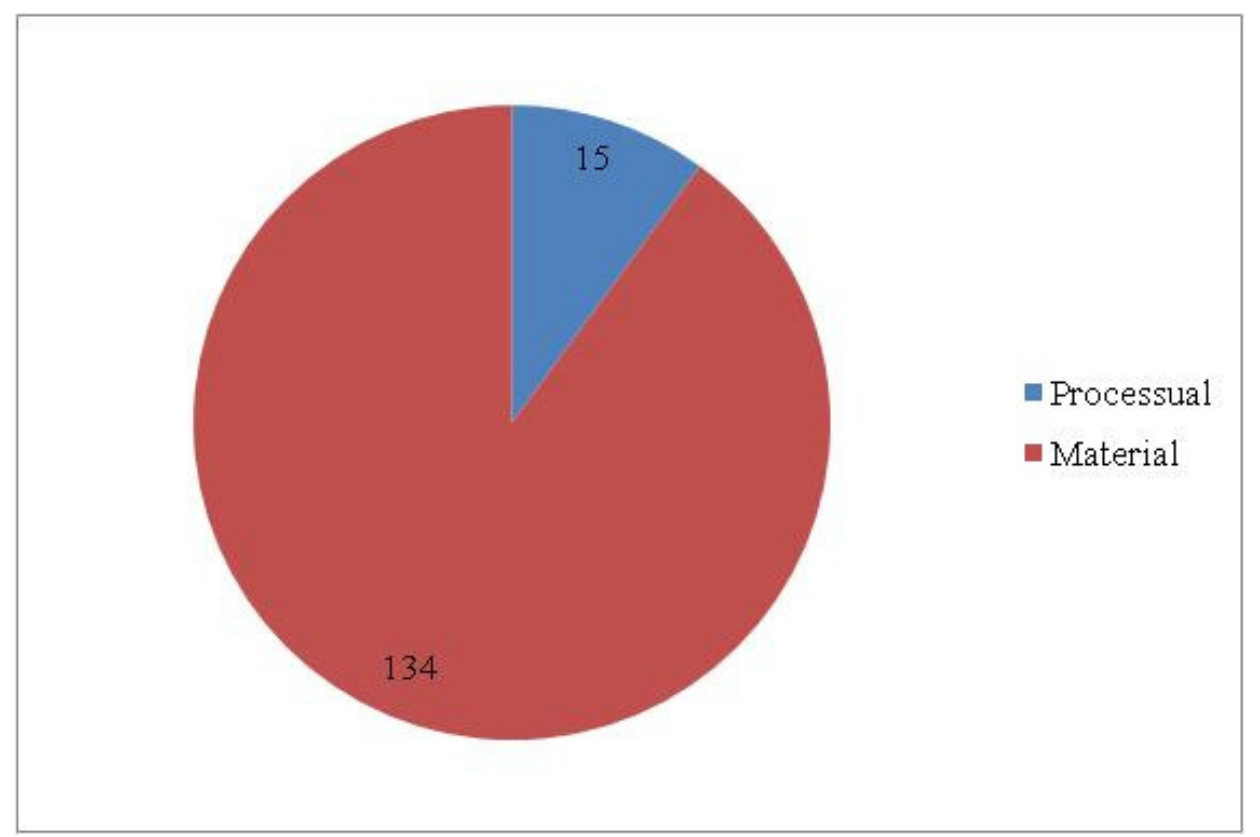


A leitura das decisões mostrou que uma variedade enorme de assuntos pode levar à alegação de violação ao princípio da congruência, havendo poucos temas constantes:

\section{Gráfico 4 - Temas de Direito Processual}

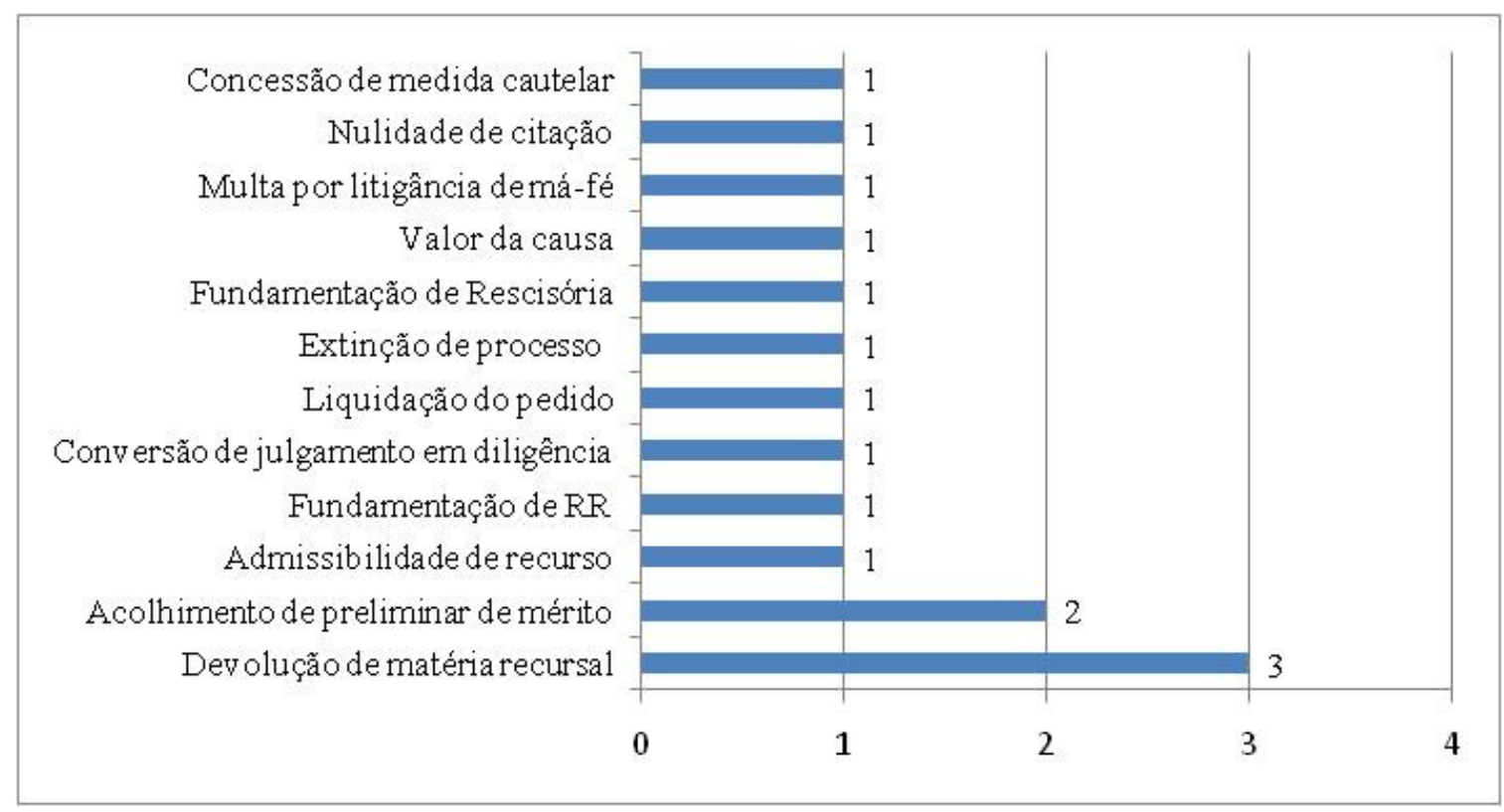

Em relação aos temas de Direito Processual, devem ser destacadas as problemáticas que envolvem o princípio da congruência e a devolução de matéria recursal, bem como o referido princípio e a liquidação do pedido, questões não abordadas no Capítulo 3 em razão dos limites deste trabalho, mas que merecem atenção pela relevância prática que a pesquisa de campo demonstrou.

Em relação aos temas de Direito Material, o levantamento de acórdãos mostrou-se um verdadeiro manual de Direito do Trabalho, tal foi a variedade de assuntos abordados!

Nota-se número expressivo de decisões que versam sobre horas extras, seguidas por salário e reintegração no emprego. Embora menos frequentes, serão analisadas com mais profundidade as decisões que envolvem responsabilidade solidária e subsidiária, contrato de trabalho com a Administração Pública, adicional de insalubridade e periculosidade, reconhecimento de vínculo empregatício e anotação em CTPS. 


\section{Gráfico 5 - Temas de Direito Material}

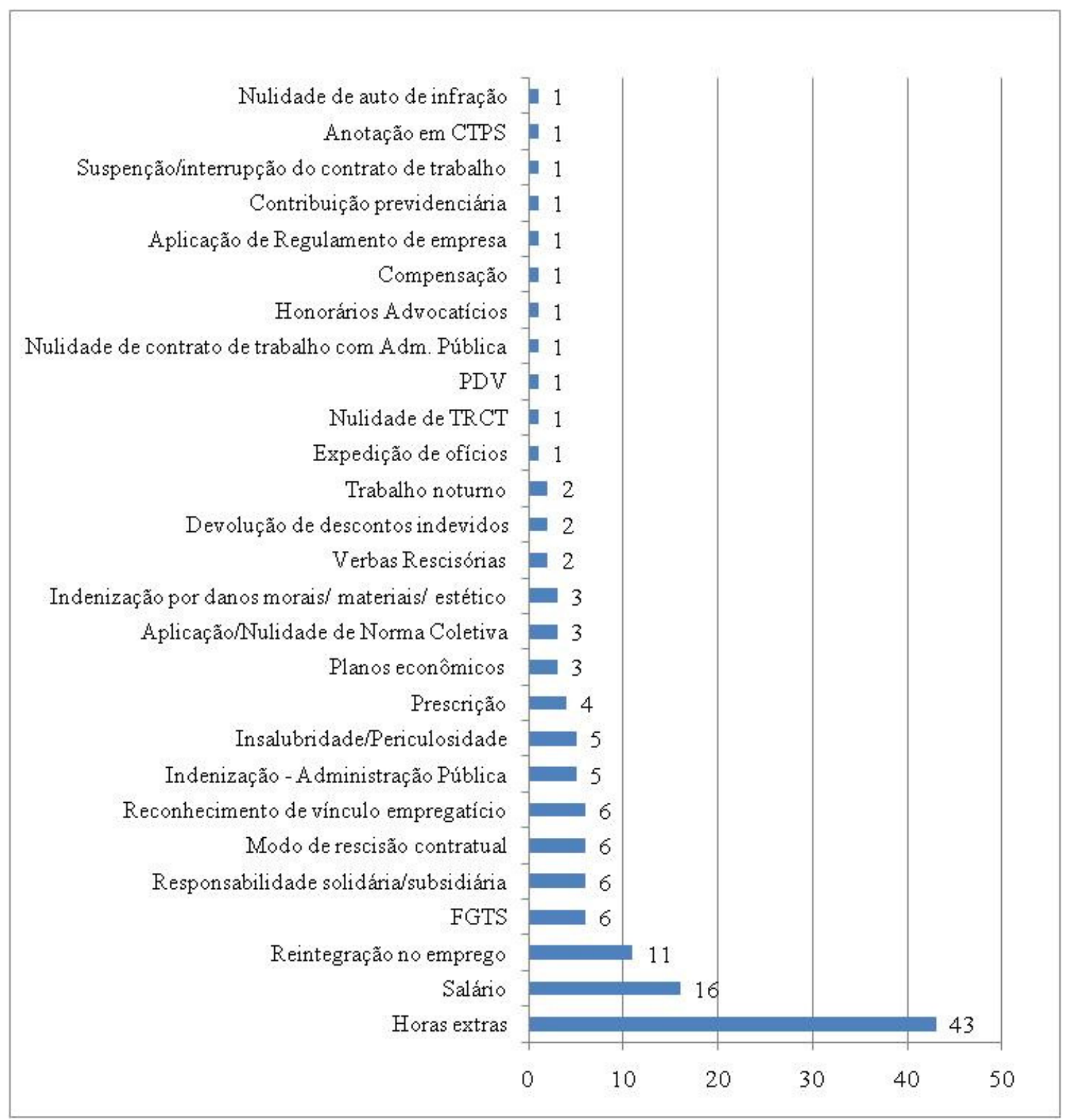

Como já foi estudado, o princípio da congruência diz respeito não apenas à adstrição do juiz ao pedido formulado pela parte, mas também aos fatos trazidos aos autos, à causa de pedir. Deste modo, das ações analisadas, em 90 não havia pedido expresso ou tal pedido foi considerado irrelevante pelo TST, em 36 o TST indicou que havia sido formulado o pedido, mas não fora apresentada a fundamentação da decisão recorrida, e no restante ficou afastada a alegação da parte de inexistência de pedido ou de causa de pedir expressos. 
Gráfico 6 - Existência de pedido e causa de pedir

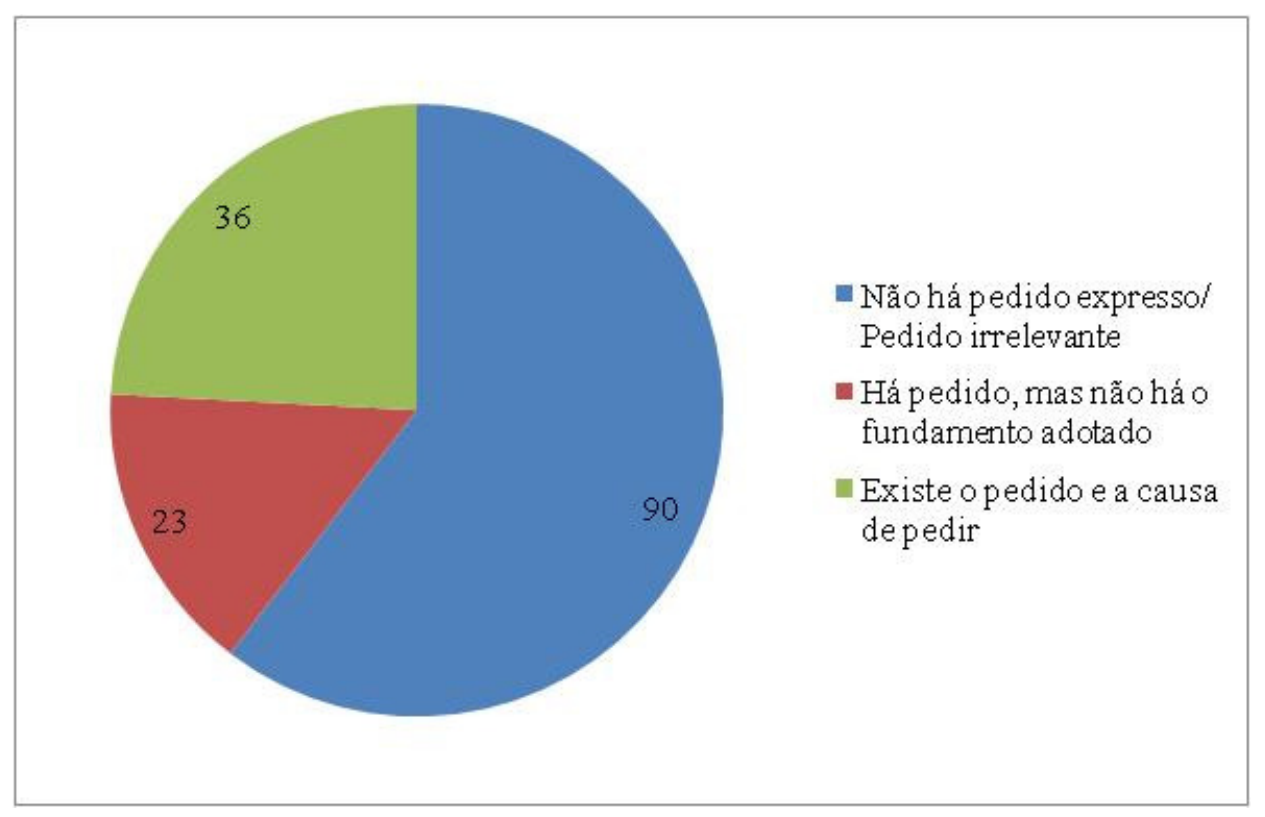

Dos 90 acórdãos em que o TST reconheceu a inexistência de formulação de pedido, em 65 não foi acolhida a alegação de violação ao princípio da congruência, mantendo-se a decisão atacada, em 24 o tribunal entendeu ter havido julgamento ultra ou extra petita, reformando a decisão anterior, e em 1, apesar de reconhecer a violação ao princípio ora estudado, o TST manteve a decisão.

Gráfico 7 - Posição do TST quando não há pedido expresso ou o pedido é irrelevante

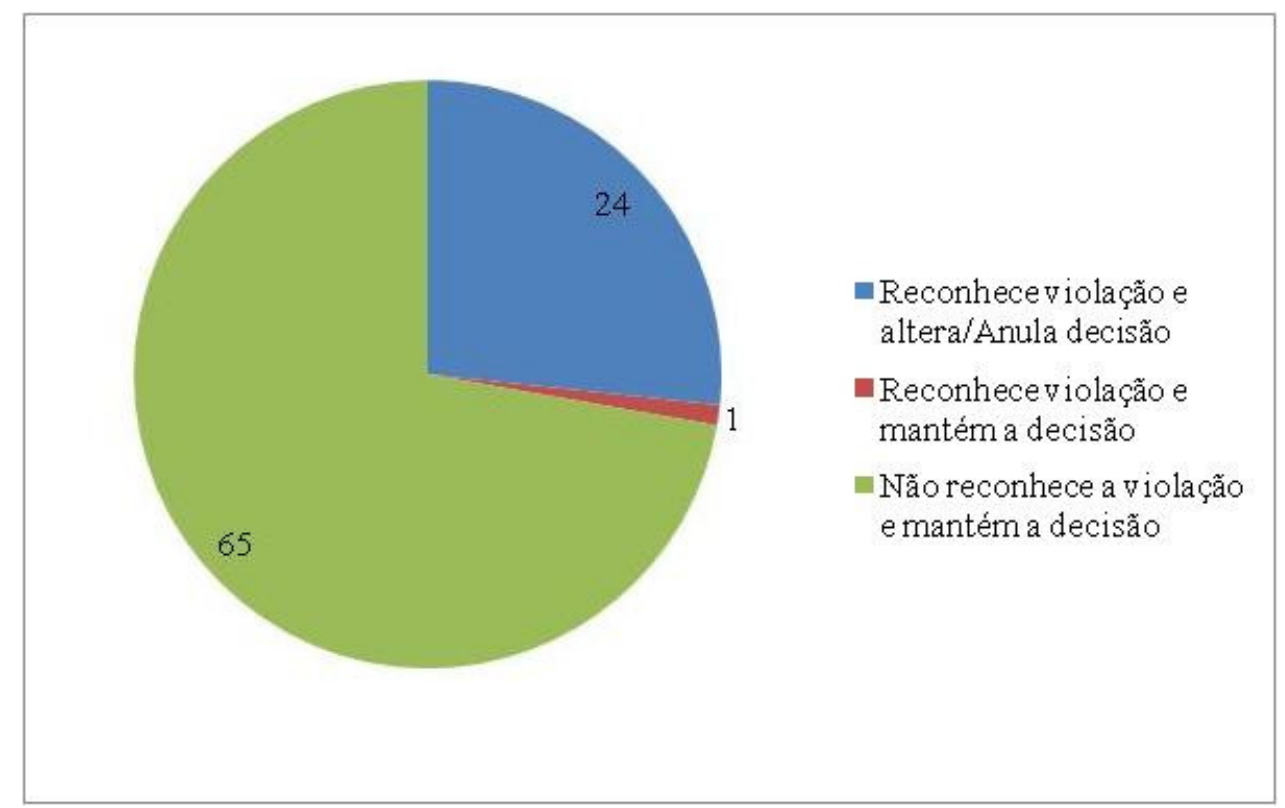


A tendência de manutenção das decisões recorridas se manteve quando a alegação de violação ao princípio da congruência estava dirigida à inexistência de causa de pedir. Assim, tem-se que, das 24 decisões atacadas sob este fundamento, 19 foram mantidas, sob o argumento de julgamento dentro dos limites da lide, e 4 foram reformadas.

\section{Gráfico 8 - Posição do TST quando há pedido, mas não há o fundamento adotado}

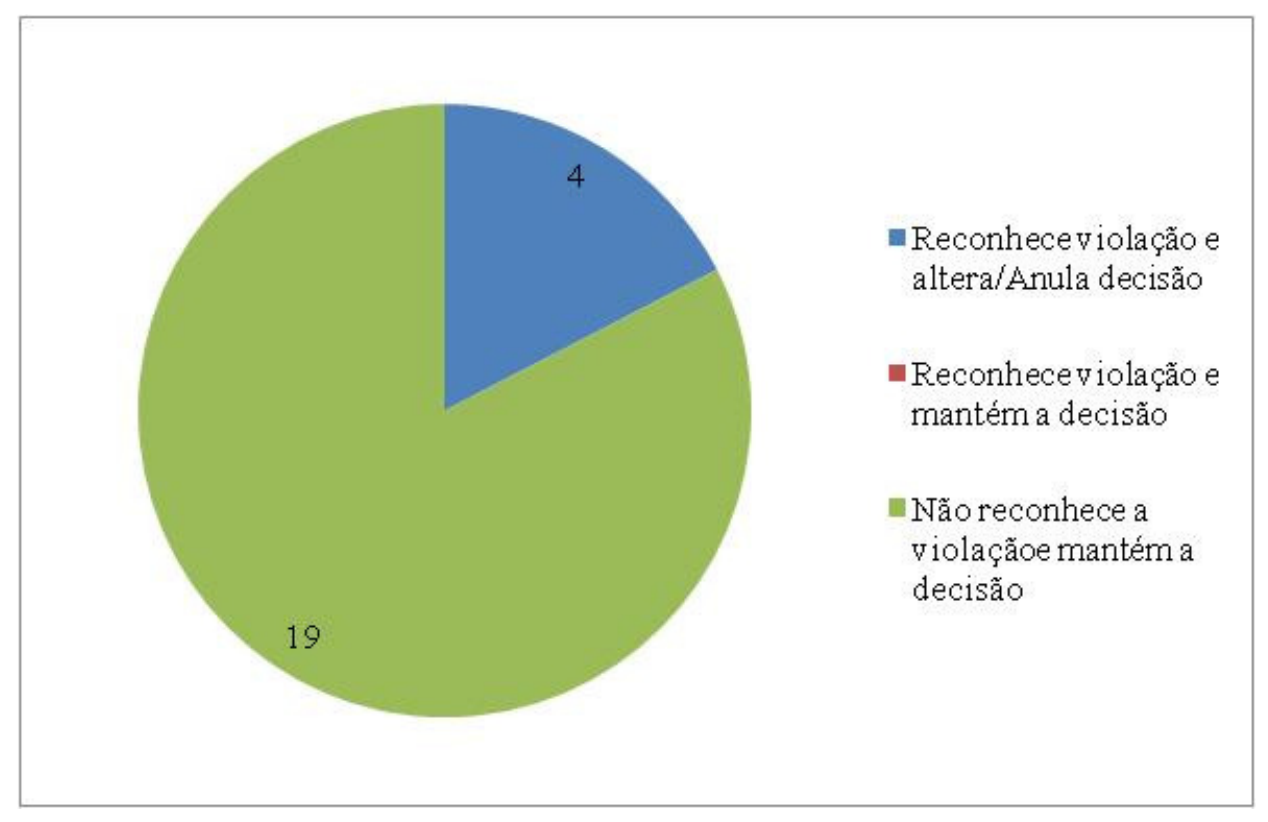

Em respeito ao disposto no artigo 93, IX, da CF, todas as decisões do TST justificaram a manutenção ou reforma das decisões recorridas. Nota-se que, por vezes, o TST utilizou-se de mais de uma justificativa para seu posicionamento, de modo que, nos próximos gráficos, a soma dos itens supera o número de acórdãos analisados.

Quando se tratou de manter a decisão alegadamente viciada pela ultra ou extrapetição, no tocante ao pedido, as principais justificativas apresentadas pelo para rejeição da reforma foram: iura novit curia ou da mihi factum, dabo tibi ius, interpretação lógica do pedido, “quem pede mais, pede menos”, livre convencimento do juiz, pedido implícito e simplicidade do Processo do Trabalho. Ainda merece atenção especial a justificativa baseada no caráter público da norma em apreço. 


\section{Gráfico 9 - Fundamentos para manutenção da decisão (pedido)}

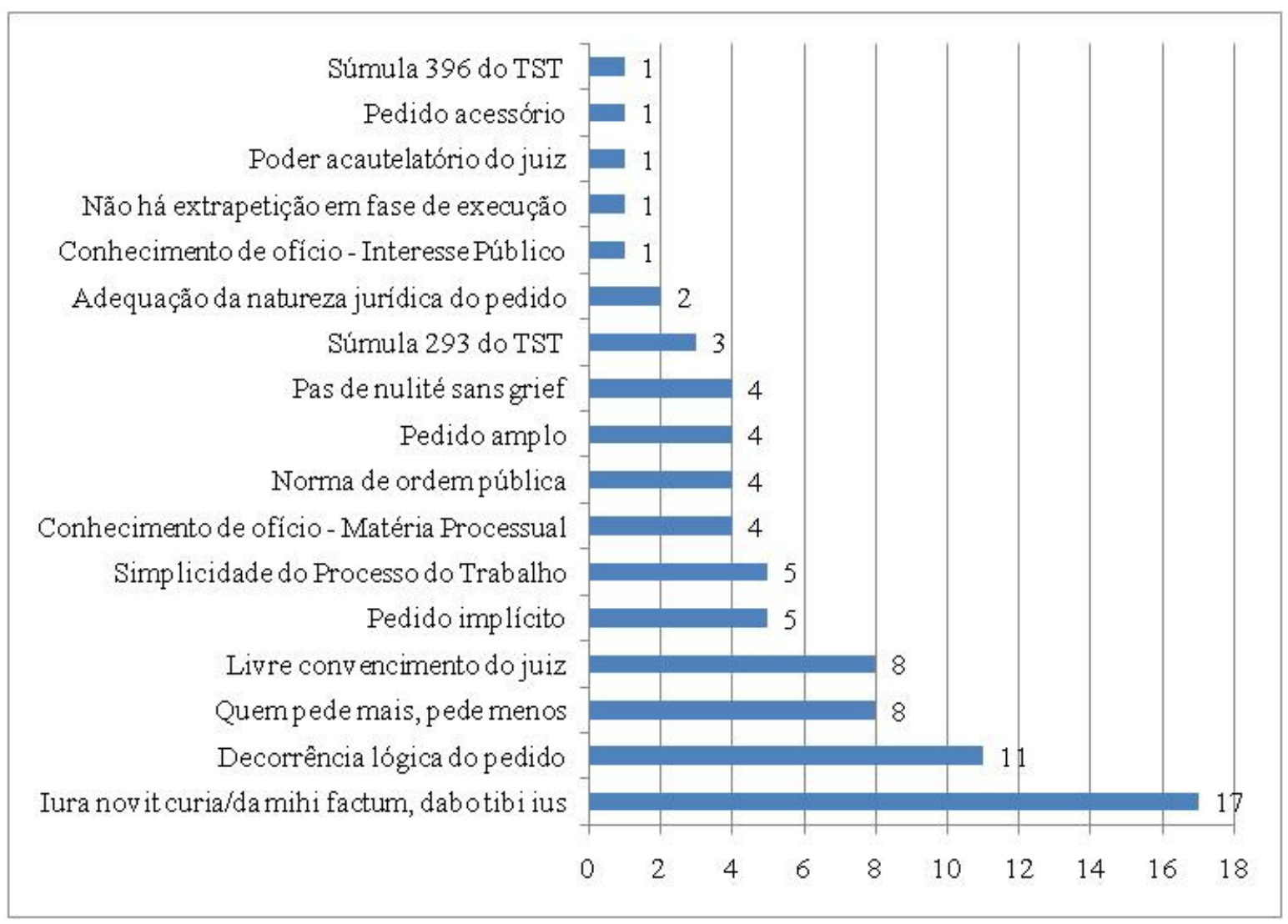

Já o acolhimento da nulidade consequente da violação do princípio da congruência, no tocante ao pedido, em regra, repetiu os ditames tradicionais, quais sejam: impossibilidade de deferimento de pedido não formulado e extrapolação dos limites objetivos da lide.

\section{Gráfico 10 - Fundamentos para reforma da decisão (pedido)}

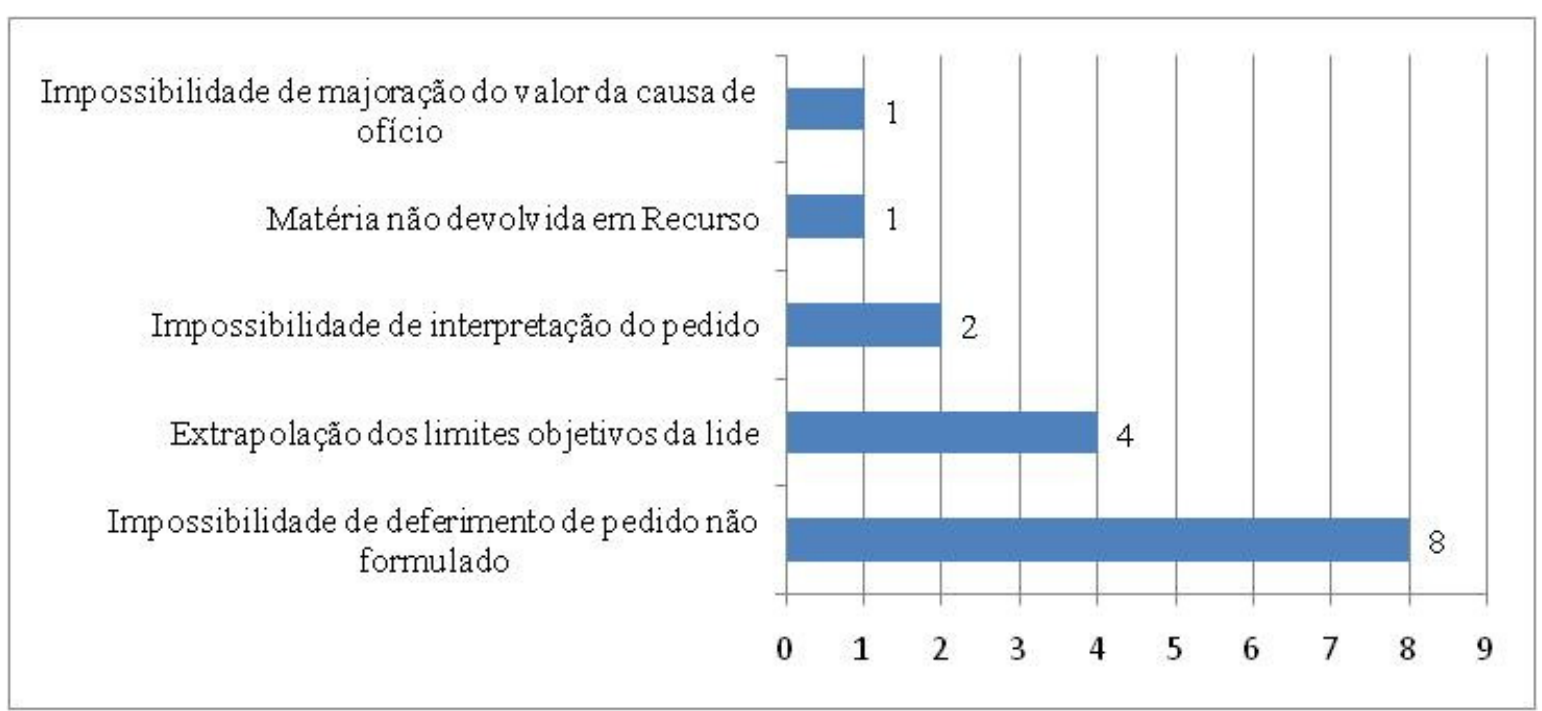


No que diz respeito à causa de pedir, mais uma vez o iura novit curia ou da mihi factum, dabo tibi ius e o livre convencimento do magistrado apareceram como justificativas predominantes para a manutenção da decisão recorridas, ao passo que, para fundamentar as reformas, o TST alegou a impossibilidade de conhecimento de ofício de matéria não alegada pelas partes:

Gráfico 11 - Fundamentos para manutenção da decisão (causa de pedir)

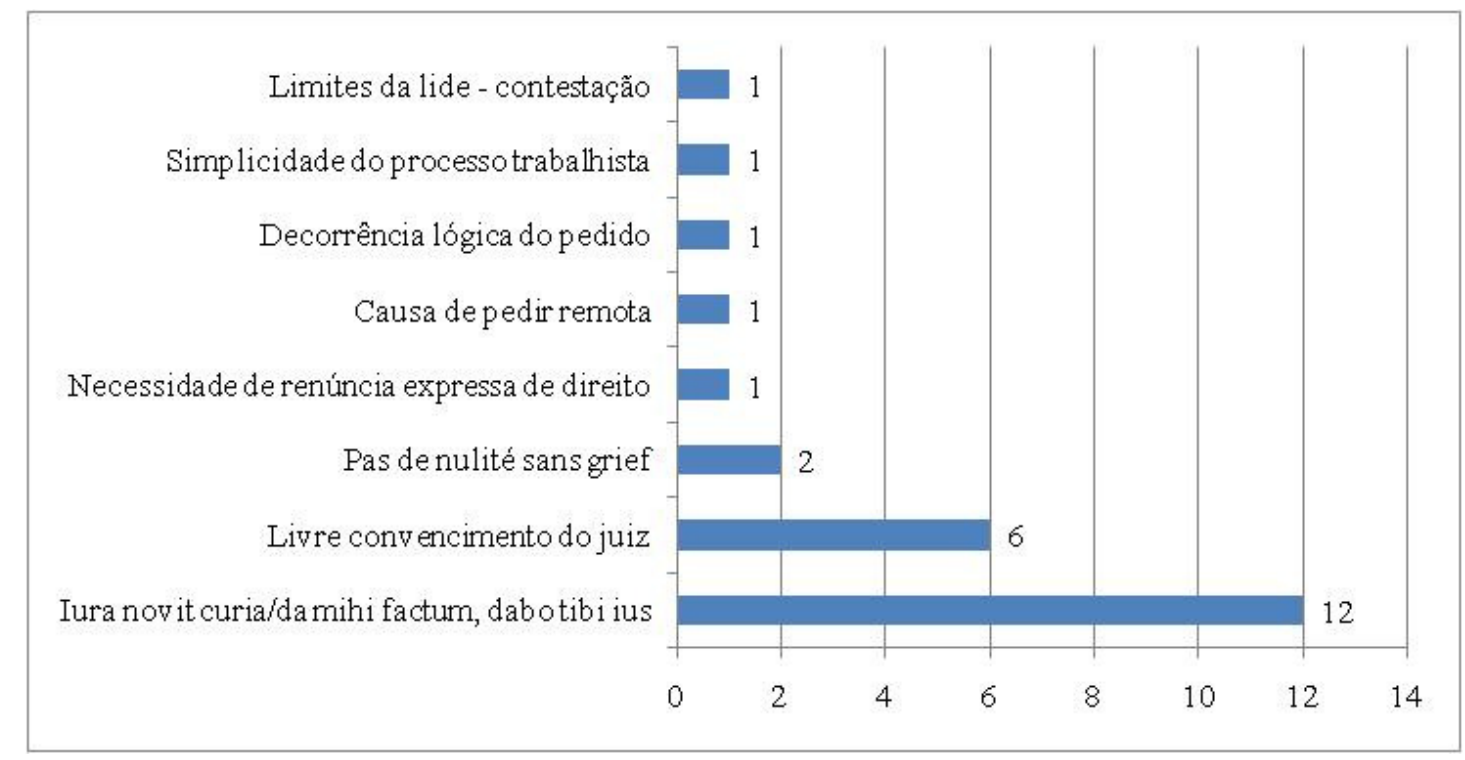

Gráfico 12 - Fundamentos para reforma da decisão (causa de pedir)

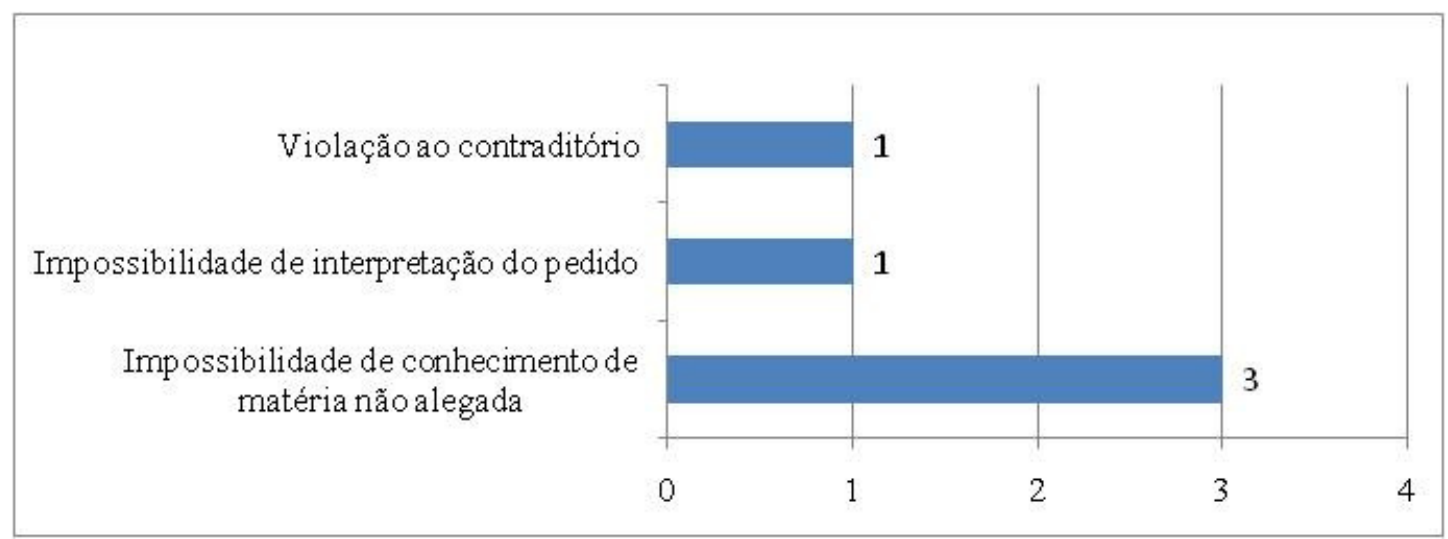




\subsection{Questões Importantes}

\subsubsection{Conceito de Ultra e Extrapetição}

Como visto no capítulo anterior, a ultra e a extrapetição podem ter consequências diversas, motivo pelo qual a doutrina esforça-se por distingui-las, não obstante a evidente proximidade semântica das duas expressões. Vallisney de Souza Oliveira, em pesquisa direcionada ao Processo Civil, identificou a "confusão" entre os conceitos no âmbito judicial:

Os tribunais algumas vezes misturam tais fenômenos. Por exemplo, a ementa abaixo diz ser caso de julgamento extra petita, porém na realidade a decisão foi ultra petita, uma vez que o juiz, além de decretar o despejo, excedeu-se ao condenar o réu a pagar os aluguéis atrasados ${ }^{198}$.

Igual situação foi observada nas decisões proferidas pelo TST, sendo que, em alguns casos, os termos ultra e extra foram usados indiscriminadamente, na mesma decisão. Embora se tenha optado por não fazer um levantamento estatístico acerca do uso dos termos pelo tribunal, é possível apontar os seguintes acórdãos como exemplo do alegado, identificados na pesquisa pelo termo ultra petita:

\begin{tabular}{|c|c|}
\hline EMENTA & DECISÃO \\
\hline $\begin{array}{l}\text { JULGAMENTO “ULTRA PETITA”. PEDIDO } \\
\text { DE INTEGRAÇÃO SALARIAL. REFLEXOS } \\
\text { DECORRENTES. }\end{array}$ & $\begin{array}{l}\text { A Eg. Quinta Turma do Tribunal Superior do } \\
\text { Trabalho, mediante o v. acórdão da lavra do Exmo. } \\
\text { Min. Gelson de Azevedo (fls. } 416 / 420 \text { ), não } \\
\text { conheceu do recurso de revista interposto pelo } \\
\text { Reclamado quanto ao tema "julgamento extra } \\
\text { petita", porquanto não reputou demonstrada a } \\
\text { ofensa indicada ao artigo } 460 \text { do CPC } \text { CP. }^{199} \text {. }\end{array}$ \\
\hline $\begin{array}{l}\text { JULGAMENTO "EXTRA PETITA". A } \\
\text { pretensão inicial deduzida pelo reclamante } \\
\text { conduzia a dois pedidos: pagamento de horas } \\
\text { extras prestadas e de reflexos de horas extras } \\
\text { realizadas e recebidas, mas que foram pagos a } \\
\text { menor. Não há julgamento além do pedido na } \\
\text { hipótese. Os autos revelam condenação pelo } \\
\text { Tribunal Regional nos limites da pretensão } \\
\text { deduzida na petição inicial. Não se reconhece a } \\
\text { violação aos arts. } 128,295 \text {, parágrafo único, inc. I, } \\
\text { e } 460 \text { do CPC e } 840, \S 1^{\circ} \text {, da CLT. Dessa forma, } \\
\text { resulta incólume o art. } 896 \text { da CLT. }\end{array}$ & $\begin{array}{l}\text { Inviável deliberar sobre o alegado julgamento extra } \\
\text { ou ultra petita, invocado à guisa de violação aos } \\
\text { arts. } 128,295 \text {, parágrafo único, inciso I, do CPC } \\
\text { c/c o art. } 840, \S 1^{\circ} \text {, da CLT, e } 460 \text { do CPC, ante a } \\
\text { ausência do requisito do prequestionamento, pois o } \\
\text { acórdão recorrido limitou-se a analisar o universo } \\
\text { fático-probatório para manter a condenação às } \\
\text { diferenças de reflexos de horas extras }{ }^{200} \text {. }\end{array}$ \\
\hline
\end{tabular}

\footnotetext{
198 OLIVEIRA, Vallisney de Souza. Nulidade da sentença e o princípio da congruência, p. 251.

${ }^{199}$ Ver Anexo 2, Decisão 1 - PROC. N ${ }^{\circ}$ TST-E-RR-469.561/98.3

${ }^{200}$ Ver Anexo 2, Decisão 22 - PROC. No TST-E-RR-753.600/2001.9
} 


\begin{tabular}{|c|c|}
\hline EMENTA & DECISÃO \\
\hline 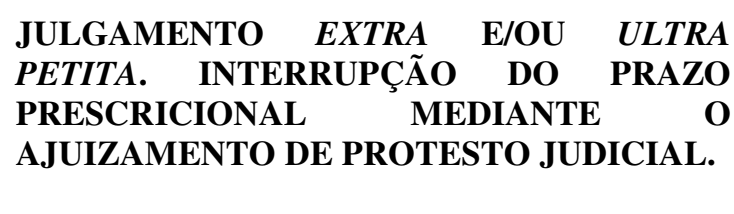 & $\begin{array}{l}\text { Convém ressaltar que o julgamento extra petita } \\
\text { resta caracterizado quando se defere parcela de } \\
\text { natureza diversa da pretendida em Juízo, ou em } \\
\text { quantidade superior, ou com objeto diverso do que } \\
\text { foi postulado }^{201} \text {. }\end{array}$ \\
\hline
\end{tabular}

Atente-se, ainda, para as decisões proferidas nos autos dos processos $n^{\circ}$ TST-EED-RR-620770/2000.0 e nº TST-E-RR-531160/1999.0. Ambas dizem respeito ao mesmo assunto, qual seja, o reconhecimento de atividade em condições insalubres em grau ou por agente distinto do indicado na petição inicial; contudo, o primeiro retornou na pesquisa pelo termo extra petita, enquanto o segundo pelo termo ultra petita. A leitura dos acórdãos não elucida as dúvidas sobre qual tipo de violação poderia ter ocorrido nestes casos. No primeiro, a ementa é a seguinte:

\begin{abstract}
JULGAMENTO ULTRA E EXTRA PETITA. ADICIONAL DE INSALUBRIDADE. AGENTE INSALUBRE DIVERSO DO INDICADO NA PETIÇÃO INICIAL. O Recurso de Revista efetivamente não alcançava conhecimento, permanecendo incólume o art. 896 da CLT, porquanto a decisão regional está em consonância com a Súmula 293 desta Corte, que tem a seguinte redação: "ADICIONAL DE INSALUBRIDADE. CAUSA DE PEDIR. AGENTE NOCIVO DIVERSO DO APONTADO NA INICIAL. A verificação mediante perícia de prestação de serviços em condições nocivas, considerado agente insalubre diverso do apontado na inicial, não prejudica o pedido de adicional de insalubridade" ${ }^{202}$.
\end{abstract}

No segundo, tem-se que:

\begin{abstract}
A Turma conheceu da Revista da Reclamada, quanto ao tema "adicional de insalubridade/julgamento "ultra petita", por divergência jurisprudencial e, no mérito, negou-lhe provimento, sob o argumento de que não configura julgamento extra petita o deferimento de adicional diverso daquele indicado na inicial, uma vez que o artigo $195, \S 2^{\circ}$, da CLT, pressupõe a realização de perícia para deferi$10^{203}$.
\end{abstract}

No caso da concessão de adicional de insalubridade por agente ou em grau diversos dos apontados na inicial, há entendimento pacificado pela súmula 293 do TST no sentido de se permitir ao juiz tal ato. Contudo, é inegável que se trata de uma flexibilização do princípio da congruência, posto que nesse caso a tutela judicial é concedida em desconformidade com o expressamente requerido na inicial, embora não haja um

\footnotetext{
${ }^{201}$ Ver Anexo 2, Decisão 30 - PROC. No TST-E-RR-626991/2000.1

${ }^{202}$ Ver Anexo 2, Decisão 111 - PROC. No TST-E-ED-RR-620770/2000.0

${ }^{203}$ Ver Anexo 2, Decisão 17 - PROC. No TST-E-RR-531160/1999.0
} 
entendimento unificado acerca da natureza dessa desconformidade (se além ou se fora do pedido) nas decisões acima transcritas.

Não obstante, em pelo menos duas decisões houve a tentativa de diferenciar os dois fenômenos:

\begin{abstract}
JULGAMENTO ULTRA E EXTRA PETITA. HORAS EXTRAS. REFLEXOS E FORMA DE CÁLCULO. O pleito inicial é o "pagamento de horas extraordinárias laboradas, seus reflexos nas demais verbas de natureza salarial" (fls. 04). Denota-se da sentença proferida apenas o deferimento da pretensão deduzida pela reclamante, no sentido do pagamento das horas trabalhadas além da $6^{\mathrm{a}}$ diária, com a determinação de reflexos legais e da forma de cálculo. O julgamento extra e ultra petita caracterizam-se ou pelo excesso na condenação ou pela concessão de pedido diverso; nenhuma das hipóteses presentes neste caso $^{204}$.
\end{abstract}

$\mathrm{E}$

AÇÃO RESCISÓRIA - JULGAMENTO “ULTRA PETITA" NÃO CONFIGURADO - INEXISTÊNCIA DE PREJUÍZO COM A ALTERAÇÃO DO CRITÉRIO DE FIXAÇÃO DAS HORAS EXTRAS CPC, ART. 460; CLT, ART. 794. 1. Mais do que o art. 128 do CPC, é o art. 460 que trata do julgamento "extra" ou "ultra petita", ao dispor que: "É defeso ao juiz proferir sentença, a favor do autor, de natureza diversa da pedida, bem como condenar o réu em quantidade superior ou em objeto diverso do que lhe foi demandado". 2. "In casu", é de se descartar de plano o julgamento "extra petita", uma vez que o pedido e a condenação foram de horas extras. Quanto ao julgamento "ultra petita", este restaria caracterizado se demonstrado que a alteração no critério de fixação do montante da condenação (de apuração pelos cartões de ponto para valor fixo de 2 horas extras diárias) importou aumento da condenação ${ }^{205}$.

As distinções apresentadas em nada diferem das feitas pela doutrina e já discutidas. Assim, há que se questionar o motivo da recorrente mistura dos dois conceitos nos acórdãos pesquisados. Por um lado, a estrutura complexa da reclamação trabalhista, recheada de pedidos normalmente ligados a um mesmo contrato de trabalho pode levar a duas posições opostas: (i) é possível entender que os pedidos de pagamento de verbas decorrentes de rescisão do contrato de trabalho sem justa causa são autônomos, constituindo julgamento extra petita aquele que condena o réu ao pagamento de férias proporcionais quando o autor deixou de mencioná-las; ou (ii) também é justificável a posição que entende ser ultra petita tal decisão, pois o juiz estaria concedendo mais verbas rescisórias do que o pleiteado... Por outro, poder-se-ia simplesmente justificar tal mistura pela falta de necessidade da distinção: ao contrário do que ocorre no Processo Civil - em que, em regra, o pedido se refere a apenas um bem da vida (ex. a casa verde) -, no

\footnotetext{
${ }^{204}$ Ver Anexo 2, Decisão 27 - PROC. No TST-E-RR-638.486/2000.8

${ }^{205}$ Ver Anexo 2, Decisão 46 PROC. No TST-RXOF e ROAR-540/2002-000-15-00.1
} 
Processo do Trabalho, o pedido costuma ser múltiplo, sendo raríssimos os casos em que a sentença é puramente extra petita e, portanto, nula. O que se observa é que o saneamento de vício de extrapetição no Processo do Trabalho leva apenas ao corte do que foi concedido fora do pedido, mantendo-se a sentença no que for congruente com o pleiteado na inicial, exatamente a consequência da sentença ultra petita.

\subsubsection{Temas de Direito Processual}

O número de decisões que versam sobre Direito Processual é significativamente menor do que aquelas cujos temas são de Direito Material do Trabalho (ver Gráfico 3), não tendo sido possível identificar a razão de tal diferença. É possível aventar a hipótese de que as partes se sentem mais confortáveis e conformadas com a atuação de ofício do juiz em tais casos; a previsão expressa de que cabe ao magistrado a direção do processo, sendo-lhe lícito determinar as diligências que acreditar necessárias, independentemente da vontade das partes ${ }^{206}$, seria a razão que as levaria a deixar de recorrer em tais casos.

Durante a elaboração deste trabalho, optou-se por não discorrer sobre a aplicação do princípio da congruência em fase de recurso e em fase de cumprimento de sentença, como já justificado. Contudo, tais temas apareceram na pesquisa realizada e serão expostos, para que possam servir de referência para futuros estudos mais aprofundados.

\subsubsection{Devolução de Matéria Recursal}

No processo $\mathrm{n}^{\mathrm{o}}$ TST-ROAR-12814/2006-000-02-00.0, discutiu-se a validade de decisão proferida em Recurso Ordinário, que concedeu ao empregado o pagamento de horas extras, embora, em suas razões recursais, o reclamante tenha se limitado a requerer a nulidade dos atos processuais ante o cerceamento de defesa. A tese da defesa foi a de que, ao conhecer de matéria não devolvida em Recurso, o tribunal teria julgado além dos limites permitidos. Ao dar provimento às alegações da empresa, a SDI-2 do TST entendeu que:

\footnotetext{
Segundo o princípio da ampla devolutividade (artigo 515 do CPC), o recurso devolve ao tribunal toda a matéria efetivamente impugnada, no entanto, essa devolução deve se ater aos limites do pedido, eis que a atividade jurisdicional do Estado está adstrita ao pedido, sob pena de haver julgamento extra petita e ultra petita, situação abominada pelo sistema processual brasileiro (artigos $2^{\circ}$,
}

${ }^{206}$ Artigos 653 e 680 da CLT. 
128 e 460 do CPC).

A ampla devolutividade do Recurso Ordinário, pelo qual o Tribunal ad quem, quando instado sobre determinada matéria deverá apreciar e julgar todas as questões suscitadas e discutidas no processo, ainda que o juízo a quo não as tenha julgado por inteiro $\left(\mathrm{CPC}\right.$, art. $\left.515, \S 1^{\circ}\right)$, fica adstrita à matéria devolvida para julgamento.

Dessa forma, tem-se que o tema relacionado às horas extras, não se tratando de questão de ordem pública, não foi devolvido ao Tribunal Regional do Trabalho da $2^{\mathrm{a}}$ Região, razão pela qual em atenção ao princípio tantum devolutum quantum appellatum, de que trata o artigo 515 do CPC, merece acolhimento a pretensão rescisória calcada no art. 485 , V, do $\mathrm{CPC}^{207}$.

Do trecho destacado, podem ser identificada uma questão importante: o princípio da congruência guarda estreita relação com a ideia de devolutividade da matéria recursal, constituindo as razões recursais - de modo similar à petição inicial - o espaço que limita a atividade jurisdicional.

Não obstante, assim como se vem defendendo até o momento no tocante à sentença, o caráter público da matéria discutida desvincula o juiz dos estritos limites impostos pelas partes também quando se trata de devolução de matéria recursal. No caso analisado, o TST entendeu que horas extras, por não configurarem matéria de ordem pública, não podem ser conhecidas sem a expressa intenção das partes.

\subsubsection{Liquidação da Sentença}

Do mesmo modo que a petição inicial pode ter falhas técnicas, a sentença também pode ser vítima das obscuridades da língua portuguesa e, apesar dos mecanismos existentes para sanar eventuais erros, não se descarta a possibilidade de que transite em julgado sentença com termos ambíguos ou de difícil compreensão.

No processo $n^{\circ}$ TST-RXOFROAR-109/2002-000-18-00.9, a empresa apresentou ação rescisória, com alegação de violação ao artigo 460 do CPC, por suposta liquidação de sentença que teria incluído verbas não discriminadas em sentença. Tal alegação, contudo, foi afastada pela SDI-2 do tribunal, que julgou:

\footnotetext{
Também não prospera a pretensão rescisória em relação ao art. 460 do CPC (julgamento extra petita).

Ocorre que o processo de execução visa tão-somente a satisfação do direito do credor a partir do que consta no título executivo, que serve de parâmetro para as decisões proferidas nesta fase e não o pedido do Exeqüente ou do Executado, de forma que se tal título não foi observado a hipótese é de violação da coisa julgada e não de extrapolação dos limites da lide não havendo que se falar, portanto, na violação apontada pelo Autor ${ }^{208}$.
}

\footnotetext{
${ }^{207}$ Ver Anexo 2, Decisão 139 - PROC. No TST-ROAR-12814/2006-000-02-00.0

${ }^{208}$ Ver Anexo 2, Decisão 124 - PROC. No TST-RXOFROAR-109/2002-000-18-00.9
} 
Neste caso, além de entender que não é aplicável a limitação do artigo 460 do CPC ao processo de execução, o TST também julgou o mérito da questão, entendendo pela legalidade do procedimento executório. No entanto, é de se destacar que o Tribunal Regional do Trabalho havia reconhecido a inexistência de menção expressa ao gatilho de abril de 1987 na sentença, mas considerou-o mero erro material, passível de correção em fase de liquidação:

\begin{abstract}
Sustenta o agravante que a inclusão, nos cálculos, do gatilho do mês de abril não deve prevalecer, haja vista que esta parcela não constou da inicial, nem dos primeiros cálculos, bem como não foi objeto de impugnação e condenação.

Improcede a alegação patronal, eis que na inicial consta 'que em abril/87 o salário do reclamante deveria ter sido reajustado para $\mathrm{Cz} \$ 11.628,00$, entretanto recebeu somente $\mathrm{CZ} \$ 8.200,00$ (...) Quer as diferenças salariais corrigidas monetariamente' (fls. 02/03). Tal pedido foi acolhido pela $r$. sentença e confirmado pelo r. acórdão regional, como dito alhures.

Apesar de o comando contido na r. decisão, realmente não constou dos primeiros cálculos na liquidação da sentença o gatilho do mês de abril/97 (fls. 89/98), fato que, de per si, não impede a retificação ocorrida nos cálculos de fls. 168/183, já que houve condenação do reajuste em questão" (fls. 79/80) 2009 .
\end{abstract}

Há que se reconhecer, portanto, que, não obstante o entendimento esposado neste acórdão, há espaço para a discussão da aplicação do princípio da congruência em fase de cumprimento de sentença.

\title{
4.3.3 Temas de Direito Material
}

A análise dos acórdãos sob a ótica do assunto de Direito Material discutido trouxe à tona dados curiosos. Há uma enorme variedade de temas - 28 , ao total -, dos quais muitos sequer aparecem no estudo doutrinário do princípio da congruência, mas que o TST considerou passíveis de conhecimento de ofício. Ademais, há assuntos cuja recorrência, como horas extras, não encontra uma explicação intuitiva para o estudioso do Direito do Trabalho, mas que, a partir deste estudo, merecem especial atenção de advogados e magistrados.

Assim, optou-se por aprofundar a análise dos acórdãos com base em critério numérico, tendo-se, ainda, selecionado algumas decisões cuja matéria, embora tenha aparecido com menos frequência nesta pesquisa, seja apontada pela doutrina como relevante.

\footnotetext{
${ }^{209}$ Ver Anexo 2, Decisão 124 - PROC. No TST-RXOFROAR-109/2002-000-18-00.9
} 


\subsubsection{Horas Extras}

De longe o tema mais recorrente nos acórdãos pesquisados, a questão do julgamento ultra ou extra petita em relação ao trabalho extraordinário prestado pelo empregado aparece sob os mais diversos aspectos. Foram selecionados os aspectos considerados mais relevantes pela quantidade de vezes que apareceram ou por sua natureza: (i) fixação de jornada de trabalho; (ii) adicional de hora extra; e (iii) nulidade de banco de horas ou de pré-contratação de serviço extraordinário.

Em 16 decisões, o que se discutia era a validade de decisão que fixou a jornada do reclamante de modo diverso do pleiteado na inicial, decorrendo o pagamento de horas extras de tal fixação. Em 15 dos casos analisados, a decisão favorável ao empregado foi mantida, mas sob justificativas diversas. Situação comum foi o deferimento de horas extras em quantidade menor ou igual à pleiteada, mas com a indicação de horários de entrada e saída diversos dos apontados na inicial. Entendeu o TST não haver nulidade de tais decisões, ante o fato de que tais jornadas tinham sido fixadas de acordo com o conjunto probatório e que a quantidade horas extras deferidas estava dentro do limite pedido:

JULGAMENTO ULTRA PETITA. LIMITES DO PEDIDO. VIOLAÇÃO AO ART. 896 DA CLT NÃO CONFIGURADA. No processo do trabalho vige o princípio da simplicidade, bastando para apreciação do pedido que conste na petição inicial os argumentos relacionados à causa de pedir e o pedido. No caso dos autos, o exame do pedido determinou o pagamento de horas extras em valor inferior ao pedido, pelo que não há se falar em julgamento ultra petita ou em violação dos dispositivos legais apontados. Embargos não conhecidos ${ }^{210}$.

$\mathrm{E}$

Ora, nada impede que o julgador, lastreado no conteúdo fático-probatório extraído dos autos, fixe a jornada contratual e daí conceda o pagamento das horas extraordinárias habitualmente prestadas. A decisão rescindenda, em assim entendendo, expressou seu livre convencimento motivado. Em conseqüência, deu a exata subsunção ao conceito contido no art. 131 do CPC, visto que sua conclusão decorreu da aplicação do princípio da persuasão racional. A apreciação e valoração das provas é livre, bastando que o Juiz atenda aos fatos e circunstâncias constantes dos autos e indique os motivos que lhe formaram o convencimento, o que, efetivamente, ocorreu no presente caso ${ }^{211}$.

Em outros casos, o pedido genérico de pagamento de horas extras, sem limitação, cumulado com pedido de arbitramento da jornada de trabalho, foi a carta

\footnotetext{
${ }^{210}$ Ver Anexo 2, Decisão 2 - PROC. No TST-E-RR-549.127/1999.6

${ }^{211}$ Ver Anexo 2, Decisão 53 - PROC. No TST-ROAR-953/2002-000-03-00.1
} 
branca para que o magistrado fixasse a jornada do empregado, deferindo-lhe o pagamento das horas extras consideradas devidas, de acordo com as provas produzidas:

HORAS EXTRAS. JULGAMENTO ULTRA PETITA. Se há pedido de horas extras sem especificação da quantidade, não se pode cogitar de julgamento ultra petita se estas horas extras foram efetivamente aferidas pelo juízo. Portanto, não se está diante de condenação em quantidade superior à que foi demandada, tendo havido observância aos termos do art. 460 do CPC, restando incólume o art. 896 da CLT $^{212}$.

De modo diverso julgou o TST quando o empregado havia, expressamente, declinado sua jornada de trabalho, e o magistrado fixou-a de modo diverso, baseado nas provas levadas aos autos:

RECURSO ORDINÁRIO ADESIVO DA RÉ. DARF. ALEGAÇÃO DE VIOLAÇÃO DOS ARTS. 128, 458, III, E 460 DO CPC. FIXAÇÃO DA JORNADA DE TRABALHO NA INICIAL. HORAS EXTRAS. JULGAMENTO ULTRA PETITA. Uma vez fixado o alcance da pretensão na inicial da ação originária, não cabia ao julgador, na sentença confirmada pelo acórdão rescindendo, decidir além dos limites da litiscontestatio, nos termos em que foi proposta, estabelecendo a jornada de trabalho pela média dos horários precisamente indicados pela própria reclamante na exordial, ainda que levando em conta outras informações presentes nos autos, como os depoimentos testemunhais tomados. Recurso adesivo desprovido, para manter a procedência da rescisória neste aspecto ${ }^{213}$.

Em outro caso, o TST manteve a decisão que condenou o empregador ao pagamento de adicional de horas extras, embora tal pedido não tenha sido formulado pelo empregado, justificando tal posição na ideia de decorrência lógica do pedido:

Por outro lado, o deferimento de adicional de horas extras não constitui
julgamento ultra petita, porquanto, se houve pedido de horas extras, é
consequência natural a adoção de um percentual para que se torne possível o
cálculo dessas horas. Esse é entendimento concentrado na Súmula 264 desta
Corte que tem a seguinte redação: "HORA SUPLEMENTAR. CÁLCULO. A
remuneração do serviço suplementar é composta do valor da hora normal,
integrado por parcelas de natureza salarial e acrescido do adicional previsto em
lei, contrato, acordo, convenção coletiva ou sentença normativa."
Assim, a condenação ao pagamento de adicional de horas extras se encontra
intimamente ligada à causa petendi declinada na petição inicial, não se tratando,
portanto, de matéria autônoma, porquanto decorre da efetiva existência do
trabalho em sobrejornada.
Não se verifica, pois, a indicada ofensa aos arts. 128 e 460 do CPC CPan $^{214}$.

Por fim, em três situações, a empresa pleiteou a reforma da decisão favorável ao empregado, a qual havia determinado o pagamento de horas extras com fundamento na nulidade da pré-contratação de horas extras ou do plano de compensação de horas. Em

\footnotetext{
${ }^{212}$ Ver Anexo 2, Decisão 36 - PROC. No TST-RR-82400-13.2001.5.12.0023

${ }^{213}$ Ver Anexo 2, Decisão 52 - PROC. No TST-ROAR-41.008/2001-000-05-00.8

${ }^{214}$ Ver Anexo 2, Decisão 34 - PROC. No TST-E-RR-568.232/1999.6
} 
duas situações, o TST entendeu que não é lícito ao magistrado conhecer de matéria não aduzida pelo autor como fundamento de sua pretensão:

EMBARGOS - JULGAMENTO EXTRA PETITA - PEDIDO DE
INDENIZAÇÃO PELA SUPRESSÃO DE HORAS EXTRAS - SÚMULA No
291/TST - ABRANGÊNCIA - RECONHECIMENTO DE PRÉ-
CONTRATAÇÃO DE HORAS EXTRAS - SÚMULA N ${ }^{\circ}$ 199/TST -
CONDENAÇÃO EM PARCELA DE NATUREZA DIVERSA DA PEDIDA

1. Não obstante o Processo do Trabalho seja orientado pelo princípio da simplicidade, consagrado no art. 840 da CLT, indispensável é que a parte autora, ao expor os fatos de que resulta o dissídio, narre a causa de pedir e deduza o pedido respectivo. Estes elementos não podem ser supridos pelo julgador, sob pena, inclusive, de se frustrar o exercício do direito de defesa pela parte adversa. 2. Nesta esteira, são aplicáveis, subsidiariamente (art. 769 da CLT), os artigos 128 e 460 do CPC, mormente no que toca ao princípio da vinculação da sentença ao pedido.

3. Na hipótese dos autos, o Reclamante limitou-se a alegar que recebia habitualmente duas horas extras diárias e que tais horas foram suprimidas em $1 / 5 / 95$, quando passou a exercer cargo diverso. Pleiteou, assim, o pagamento de indenização, na forma da Súmula $\mathrm{n}^{\circ} 291$ do TST. Nada afirmou quanto a eventual contratação de serviço suplementar no momento da admissão, nem deduziu pedido nesse sentido.

4. Desse modo, a sentença, ao deferir a percepção de horas extras, por considerar nula a pré-contratação de jornada suplementar, aplicando a Súmula no 199 do TST, decidiu a lide além dos limites em que foi proposta, incorrendo, assim, em julgamento extra petita ${ }^{215}$.

Porém, em caso similar, o TST manteve a decisão anterior que havia considerado nulo o acordo de compensação de horas, embora reconhecendo a ausência de formulação específica de tal causa de pedir. Justificou tal posição por ter a questão da validade do banco de horas integrado a lide, por iniciativa do empregador:

No caso concreto, a condenação ao pagamento das horas extraordinárias
decorreu do pedido formulado pelo autor, observando estritamente os limites do
que postulado. O exame da questão relativa à validade do regime de
compensação decorreu da argumentação expendida pela própria reclamada em
sua defesa. Nessa hipótese, não se caracteriza julgamento extra petita, pois há
congruência entre o que postulado e o que deferido pelo julgador. Não há falar,
desse modo, em violação direta dos artigos 128 e 460 do Código de Processo
Civil $^{216}$.

Não se pode identificar com precisão o motivo da elevada recorrência do tema "horas extras" em pesquisa realizada sobre o princípio da congruência, mas é possível arriscar ao menos uma razão provável, que consiste no fato de que o direito ao pagamento sob tal rubrica depende, majoritariamente, da produção de prova testemunhal, o que pode gerar certas divergências entre o descrito na inicial e o consignado em ato. Ressalta-se,

${ }^{215}$ Ver Anexo 2, Decisão 14 - PROC. No TST-E-RR-670.589/2000.2

${ }^{216}$ Ver Anexo 2, Decisão 109 - PROC. No TST-E-RR-593751/1999.9 
contudo, que tais discrepâncias não devem ser interpretadas contra o empregado, especialmente quando se comprova o trabalho extraordinário.

\subsubsection{Salário}

Embora tenham sido identificados 16 acórdãos sobre o tema "salários", não foi observada uma problemática constante, como nos próximos subitens. Assim, foram selecionadas algumas decisões para serem estudadas mais a fundo, sem que se possa, contudo, identificar um posicionamento jurisprudencial do TST sobre o direito material nelas discutido.

Em decisão que abarcou desde a imperatividade da norma trabalhista, passando pela decorrência lógica do pedido, até a simplicidade do Processo do Trabalho, a SDI-1 considerou legal o julgamento que determinou a incorporação de "prêmio" e "gratificação" a todas as verbas de natureza salarial, de acordo com o formulado na causa de pedir, embora tal pleito não tenha sido formulado no item do pedido:

\footnotetext{
Mesmo que assim não fosse, a tese sustentada pelo Recorrente é ilógica: deferida a integração de parcelas no salário, o cálculo das demais vantagens que tenham o salário como base automaticamente deveria considerá-la, ainda que tanto não tivesse sido postulado. Entendimento contrário implicaria em reconhecer-se um valor para o salário (decorrente das integrações) e outro valor para cálculo, v.g., do aviso prévio, o que é absurdo.

(...)

Resulta daí ser irrelevante a circunstância de, no pedido lançado na alínea "g" da petição inicial, não constar formulação expressa no tocante aos reflexos decorrentes da postulada integração salarial.

Primeiro, porque, conforme exposto, o objetivo visado pelo Reclamante, com o pedido de integração das referidas verbas ao seu salário, consiste precipuamente no deferimento das diferenças daí decorrentes, conforme facilmente se extrai dos fatos narrados na petição inicial.

Segundo, porque, como se sabe, a simplicidade e a informalidade por que se norteia o processo trabalhista, em que ainda prevalece o "jus postulandi" das partes (CLT, art. 791), não se compadece de rigor formal na formulação do pedido, tal como se verifica no âmbito do processo civil ${ }^{217}$.
}

Temas que causam confusão entre os que atuam na Justiça do Trabalho são a equiparação salarial, desvio de função, acúmulo de função e substituição. Embora sejam, tecnicamente, bem distinguíveis, na prática a linha que os separa é tênue. Em três acórdãos sobre o assunto, apesar de haver reconhecimento pelo tribunal de "falta de boa técnica" na elaboração do pedido, houve manutenção das decisões que haviam determinado o

${ }^{217}$ Ver Anexo 2, Decisão 1 - PROC. No TST-E-RR-469.561/98.3 
pagamento de diferenças salariais em decorrência do exercício de atividade incompatível com a contratada ou por ausência de isonomia entre os empregados.

Em um dos casos, a recorrente alegou que houve violação ao princípio da congruência, pois, embora o reclamante tenha postulado diferenças em virtude do exercício da função de Coordenador, em substituição, o TRT concedeu as diferenças, não obstante ter assumido que não houvera substituição. Tal alegação foi rejeitada:

O que ficou expresso, quer no Regional, quer na Turma, é que o pedido do Reclamante envolveu diferenças salariais pelo exercício da função de coordenador, e que o pedido foi julgado procedente porque configurado o exercício dessa função, pelo que é irrelevante, na hipótese, se o pedido decorreu, ou não, de substituição, já que o efetivo exercício do cargo, sem a paga da remuneração respectiva, é que gerou o pedido de diferenças salariais, independentemente de ter sido antes ou após a saída do anterior exercente da mesma $^{218}$.

De modo similar, a SDI-1 também afastou a pretensão de se ver reformada decisão que concedeu ao reclamante diferenças salariais em decorrência da incidência do princípio da isonomia, em razão do Plano de Cargos e Salários da empresa:

O Tribunal Regional consigna que, apesar da imprecisão técnica da petição inicial, há pedido de "equiparação salarial ou isonomia salarial" e, na fundamentação, o reclamante argumenta que era gerente de vendas, conforme organograma da empresa, pretendendo receber diferenças salariais considerando que outros gerentes de venda percebiam salário superior.

(...)

Dessarte, não há falar em julgamento ultra ou extra petita, uma vez que as diferenças salariais deferidas na sentença, em razão da percepção pelo reclamante de salário inferior aos de seus colegas no período em que ocuparam o mesmo cargo, não extrapola nem difere da pretensão formulada na petição inicial.

Saliente-se que, em face do princípio da simplicidade que informa o processo do trabalho, os requisitos da petição inicial, previstos no art. 840 da CLT, não observam o rigorismo e as formalidades das normas de processo civil, que têm a sua aplicação subsidiária mitigada nessa hipótese.

Ilesos os arts. 128 e 460 do CPC, não havendo falar, portanto, em afronta aos arts. 896 da CLT e $5^{\circ}$, incs. XXXV, LIV e LV, da Constituição da República ${ }^{219}$.

O TST também manteve condenação em diferenças salariais, não obstante a falta de pedido expresso, por considerar que foram devidamente pleiteadas na causa de pedir:

A alegação foi rejeitada ao entendimento de que “... o pedido de diferenças
salariais consta no item I da inicial. Os fatos e fundamentos jurídicos (causa
de pedir) relativos às conseqüências pretendidas estão articulados fls. 6/9,
denominado pelo autor 'do enquadramento"” (fl. 99).
Daí se percebe ter o juízo prolator da decisão rescindenda se lastreado na
interpretação das alegações expendidas tanto na inicial da reclamação trabalhista
quanto na defesa, sendo intuitivo que a condenação ao pagamento das diferenças

${ }^{218}$ Ver Anexo 2, Decisão 77 - PROC. No TST-E-RR-172/2000-020-15-00.4

${ }^{219}$ Ver Anexo 2, Decisão 106 - PROC. No TST-E-ED-ED-ED-RR-81277/2003-900-04-00.8 
salariais decorreu da aplicação do disposto no art. 126 do CPC.

Respaldada a decisão no princípio do iura novit curia, não há falar na existência de julgamento extra petita a autorizar a procedência da pretensão rescindente por ofensa aos dispositivos invocados na inicial ${ }^{220}$.

Por fim, destacam-se duas decisões sobre o tema "salário" em que houve o reconhecimento de violação ao princípio da congruência, reformando-se a decisão atacada, ou mantendo-se decisão no mesmo sentido.

No primeiro caso $^{221}$, o reclamante, tendo trabalhado por 29 anos, pediu o pagamento proporcional de gratificação por 30 anos de serviços. Sua pretensão foi afastada por falta de amparo legal, tendo o magistrado, contudo, deferido o pagamento da gratificação por 25 anos de serviços, que havia sido paga na ocasião devida, conforme declaração do próprio empregado. No segundo caso ${ }^{222}$, o empregado pleiteou o pagamento de diferenças salariais, tendo-lhe sido deferido o pagamento dos salários integrais, embora tenha havido confissão do autor acerca do pagamento parcial da remuneração!

Há que se reconhecer, contudo, que o acerto da decisão foi menos pela problemática da ultra ou extrapetição e mais pela inexistência do direito material pleiteado.

\subsubsection{Reintegração no Emprego}

Como já explicado no item 3.5.2.9, a súmula 396 do TST exclui expressamente do vício da extrapetição a decisão que concede o pagamento dos salários do período estabilitário com base em pedido de reintegração. Foram identificadas 11 decisões que versaram sobre os mais diversos aspectos da reintegração, sendo que apenas 3 dizem respeito especificamente à citada súmula. Em duas delas, o TST entendeu ter havido pedido sucessivo de pagamento de salários:

\footnotetext{
Constou como pedido sucessivo na reclamação:

"não sendo viável a reintegração, seja a reclamada condenada ao pagamento, em forma de indenização, de todos os salários, valores fundiários, valores rescisórios e demais benefícios deferidos à categoria, tudo data do afastamento até o fim da estabilidade de 12 (doze) meses" (fls. 07)

(...)

Com efeito, verifica-se que o reclamante pleiteou o pagamento de indenização substitutiva correspondente a todas as verbas salariais e rescisórias do período estabilitário. A condenação se deu, portanto, dentro dos limites do pedido, não havendo falar em violação aos arts. 128 e 460 do CPC.

Dessa forma, a condenação observou os limites da lide, razão por que não há falar em julgamento ultra petita ${ }^{223}$.

${ }^{220}$ Ver Anexo 2, Decisão 146 - PROC. Nº TST-ROAR-69100-45.2006.5.06.0000. Grifos no original.

${ }^{221}$ Ver Anexo 2, Decisão 76 - PROC. No TST-E-RR-459.147/1998.7

${ }^{222}$ Ver Anexo 2, Decisão 131 - PROC. N ${ }^{o}$ TST-ROAR-6.221/2002-909-09-00.3

${ }^{223}$ Ver Anexo 2, Decisão 32 - PROC. No TST-E-ED-RR-2576/2002-431-02-00.1
} 
Ainda que não relacionadas à súmula, outras decisões sobre o tema "reintegração no emprego" merecem especial atenção. A primeira discutiu a violação do princípio da congruência em decisão que determinou a reintegração do empregado, que havia formulado pedido de readmissão. Neste caso, houve reconhecimento de julgamento fora dos limites da lide, pois o tribunal entendeu não estar contido no pedido de readmissão, o pedido de reintegração:

Do quadro fático delineado pelo v. acórdão embargado, conclui-se que o Reclamante, detentor da estabilidade decenal de que trata o artigo 492 da CLT, postulou o reconhecimento da unicidade contratual e sua readmissão no emprego ao argumento de que aposentadoria espontânea não extingue o contrato de trabalho.

As decisões recorridas, por sua vez, mantiveram a condenação à reintegração com o fundamento de que o pedido deduzido teria sido correspondente à "volta ao emprego".

Nesse contexto, conclui-se que houve julgamento extra petita, uma vez que o pedido de reintegração não pode ser considerado como contido no de readmissão ${ }^{224}$.

Há que se reconhecer, contudo, a rigidez da decisão supracitada, pois seria admissível conhecer do pedido de reintegração pelo princípio do da mihi factum, dabo tibi ius, tendo em vista que o empregado demonstrou ser detentor de estabilidade decenal, cuja consequência no caso de dispensa injustificada é a reintegração no emprego. Assim havia entendido a $1^{\text {a }}$ Turma do TST:

O Tribunal de origem manteve a determinação de reintegração do reclamante, assinalando sua eleição para membro da CIPA $^{225}$. Por outro lado, rejeitou a argüição de julgamento ultra petita, porquanto houve pedido alternativo de condenação das verbas decorrentes da estabilidade, caso não fosse readmitido. Todavia, não sendo o caso de readmissão, mas de reintegração, o comando jurisdicional nesse sentido observava os limites da lide ${ }^{226}$.

Por fim, dois acórdãos sobre reintegração no emprego decidiram sobre a pretensão de ver anulada decisão que concedeu tal direito ao empregado, mas sob fundamento diverso do alegado na inicial. Ao não reconhecer a violação alegada, as decisões aplicaram precisamente o princípio do iura novit curia, reafirmando com rigor a desnecessidade de indicação do fundamento legal da pretensão das partes.

A Turma não conheceu do recurso de revista, sob o fundamento de que:
“(...) Assim, não há falar em julgamento fora do pedido, que se restringiu à
reintegração, tampouco em julgamento distanciado da causa de pedir, que foi a

${ }^{224}$ Ver Anexo 2, Decisão 108 PROC. No TST-E-RR-726.121/2001.1

${ }^{225}$ A leitura do acórdão não deixa claro se é hipótese de estabilidade decenal ou do empregado cipeiro, tendo em vista que há referência às duas situações. Para o fim a que se propõe este estudo, contudo, não há dano nesta confusão.

${ }^{226}$ Ver Anexo 2, Decisão 108 - PROC. No TST-E-RR-726.121/2001.1 
nulidade da dispensa. O fundamento jurídico que ampara a pretensão do autor, segundo o brocardo latino da mihi factum dabo tibi ius, é de conhecimento do juiz, incumbindo à parte somente a indicação dos fatos e dos fundamentos que amparam a pretensão."

(...)

Sustenta o reclamado que o não-conhecimento de seu recurso de revista implica ofensa ao artigo 896 da CLT.

Alega que o Decreto Estadual no 21.325/91 não foi invocado na petição inicial, mas apenas nas contra-razões ao recurso ordinário, de forma que o e. Regional, ao fundamentar sua decisão no referido decreto, afasta-se do pedido e da causa de pedir e viola os artigos 264, Parágrafo Único, 321 do CPC e 5º, LV, da Constituição Federal. Transcreve aresto para confronto a fl. 576.

Sem razão.

De acordo com as premissas fáticas consignadas no acórdão do Regional e reproduzidas pela e. Turma, não está caracterizado o julgamento extra petita, na medida em que o pedido é de reintegração e a causa de pedir foi a nulidade da dispensa.

$\mathrm{O}$ fato de o Regional ter se fundamentado em decreto estadual para concluir que estava a reclamada obrigada a fundamentar o ato de dispensa, não significa que há julgamento extra petita 227 .

Nesta outra decisão, o magistrado entendeu pela procedência do pedido de reintegração com base no artigo 118 da Lei $n^{\circ}$ 8.213/91, embora a inicial houvesse indicado o artigo 93 do mesmo diploma para embasar seu pedido. Não apenas a SDI-1 considerou legal tal decisão, como apresentou entendimento curioso acerca do conceito de julgamento extra petita:

Sucede que os arts. 128 e 460, do CPC vedam apenas o julgamento fora do pedido, mas não impedem o acolhimento do pedido com base em distinta causa de pedir, pois, como bem ressaltou a Eg. Turma, ao juiz cabe aplicar aos fatos o direito que considerar disciplinador da matéria, conforme os princípios "iura novit curia" e "da mihi factum, dabo tibi ius" ${ }^{228}$.

\subsubsection{Responsabilidade Solidária e Subsidiária}

Em 6 dos acórdãos levantados, a alegação de violação ao princípio da congruência relaciona-se ao fato de ter havido condenação em responsabilidade subsidiária em verbas trabalhistas, a despeito de haver formulação de pedido apenas requerendo a responsabilidade solidária da empresa reclamada. Mesmo reconhecendo a inexistência de pedido expresso, em nenhum dos casos foi reconhecida a extra ou a ultra petição, com fundamento nos seguintes argumentos: (i) o pedido de responsabilidade solidária é amplo e engloba o de responsabilidade subsidiária; (ii) iura novit curia

${ }^{227}$ Ver Anexo 2, Decisão 78 - PROC. No TST-E-RR-416.933/98.3

${ }^{228}$ Ver Anexo 2, Decisão 71 - PROC. No TST-E-RR-640.811/00.6 
(adequação do pedido ao caso concreto); e (iii) matéria da condenação não é estranha à lide. Assim, destacam-se os seguintes trechos, para elucidar os argumentos utilizados pelo TST:

(...) o pedido de condenação solidária é mais amplo e abrange o de condenação subsidiária, não havendo, portanto, que se cogitar de julgamento fora dos limites da litiscontestatio.

(...)

A matéria relativa à condenação em responsabilidade subsidiária, quando a delimitação do pedido refere-se a terceirização e o pedido objeto da reclamação trabalhista é de responsabilidade solidária, não possibilita se antever julgamento fora dos limites da lide, quando o juiz adequa o pedido ao caso concreto, condenando em pedido menor do que o que constou do rol da inicial.

(...)

O princípio que se encontra agregado à impossibilidade de julgamento fora dos limites da lide, remete apenas à proteção da parte para que não seja onerada, quando não há pedido. Havendo pedido, e a v. decisão procedendo tão-somente a adequação dele, imputando à parte condenação menor do que a pretendida, não há se falar na ofensa dos dispositivos legais indicados, arts. 128 e 460 do $\mathrm{CPC}^{229}$.

$\mathrm{E}$

Cumpre ressaltar que a condenação subsidiária do CEFET não importa em julgamento extra petita. A responsabilidade solidária, por ser mais ampla, engloba a subsidiária de menor prejuízo ao demandado.

A condenação subsidiária não se trata, portanto, de matéria estranha à lide, não ficando demonstrada a hipótese de que o acórdão rescindendo decidiu estranhamente à causa de pedir, permanecendo, pois, intactos os artigos $128 \mathrm{e}$ 460 do $\mathrm{CPC}^{230}$.

Como já adiantado no item 3.1, nestes casos, o TST claramente adotou posição no sentido de considerar a possibilidade dentro dos limites da lide, sem se restringir aos exatos termos propostos, à literalidade do pedido. Trata-se do que se classificou no Gráfico 9 como "quem pede mais, pede menos".

Em caso de natureza semelhante, a alegação de violação ao princípio da congruência baseava-se no fato de o juiz ter reconhecido a responsabilidade solidária da empresa em razão da existência de grupo econômico entre as rés, embora a causa de pedir tivesse indicado a existência de sucessão de empregadores. Neste caso, não se trata de ausência de pedido, mas de conhecimento de fato supostamente não alegado nos autos. Contudo, o TST embora tenha se coadunado com a posição do tribunal inferior acerca da falta de técnica da petição inicial, não se sensibilizou e manteve a decisão anterior,

\footnotetext{
${ }^{229}$ Ver Anexo 2, Decisão 87 - PROC. No TST-E-RR-83582/2003-900-02-00.5

${ }^{230}$ Ver Anexo 2, Decisão 40 - PROC. No TST-RXOFROAR-801086/2001.3
} 
justificando-se, mais uma vez, pela semelhança de ambos os temas e pelo princípio de que o juiz conhece o Direito:

\begin{abstract}
A petição não prima pela melhor técnica, pois confunde sucessão com grupo econômico, postulando a condenação das duas reclamadas, e não a condenação da sucessora. No entanto, a reclamante busca, com clareza, a condenação solidária das duas reclamadas, presumindo-se que as duas continuem atuando.

(...)

Para se concluir pela existência de julgamento extra petita ou ultra petita, é necessário que a decisão proferida tenha natureza claramente diversa do objeto pretendido, como disposto no artigo 460 do Código de Processo Civil.

$\mathrm{Na}$ hipótese dos autos, impossível se visualizar a ofensa literal e direta aos artigos 128, 460, e 515 do Código de Processo Civil ao argumento de que não se analisou a causa de pedir. Isso, porque o exame da pretensão rescindente pautada em alegado julgamento "extra petita", em realidade, se limita ao cotejo entre a pretensão formulada e a tutela deferida na demanda originária ${ }^{231}$.
\end{abstract}

Como se vê, embora não tenha havido menção à simplicidade do Processo Trabalhista nesta decisão, é certo que tal espírito permeou todas as decisões no sentido de conhecer a pretensão dos reclamantes, garantindo-lhes a devida responsabilização daqueles que se beneficiaram de seu trabalho.

\title{
4.3.3.5 Contrato de Trabalho com a Administração Pública
}

Trata-se de tema de especial interesse não apenas para os estudiosos do Direito Processual, mas também para os que estudam o Direito Material nas relações de trabalho com a Administração Pública. Em 5 acórdãos, a problemática pode ser assim descrita: os reclamantes foram a juízo pleitear vínculo empregatício e verbas rescisórias perante a Administração Pública, mas por conta do óbice do artigo 37, II, da CF, o contrato de trabalho foi declarado nulo. Ocorre que, em vez de se aterem ao disposto na súmula 363 do $\mathrm{TST}^{232}$, os magistrados concederam aos reclamantes "indenização substitutiva" das verbas salariais, como forma de afastar o enriquecimento ilícito do empregador. Ressalta-se, ainda, que, dos 5 casos analisados, em apenas 1 havia formulação de pedido sucessivo de pagamento de indenização, sendo que no restante ficou patente a inexistência de formulação de tal pleito.

\footnotetext{
${ }^{231}$ Ver Anexo 2, Decisão 145 - PROC. No TST-RO-491100-57.2008.5.04.0000

232 TST Súmula no 363 - Res. 97/2000, DJ 18.09.2000 - Republicação - DJ 13.10.2000 - Republicação DJ 10.11.2000 - Nova Redação - Res. 111/2002, DJ 11.04.2002 - Nova redação - Res. 121/2003, DJ 21.11.2003. Contratação de Servidor Público sem Concurso - Efeitos e Direitos. A contratação de servidor público, após a CF/1988, sem prévia aprovação em concurso público, encontra óbice no respectivo art. 37, II e $\S 2^{\circ}$, somente lhe conferindo direito ao pagamento da contraprestação pactuada, em relação ao número de horas trabalhadas, respeitado o valor da hora do salário mínimo, e dos valores referentes aos depósitos do FGTS.
} 
Em primeiro lugar, há que se elogiar o posicionamento dos magistrados que afastam a aplicação da referida súmula, pois, ao conceder indenização substitutiva, ficaram mais próximos de estabelecer o status quo ante do empregado, e tiraram da Administração Pública a prerrogativa de impunidade que parece lhe ser inerente quando se trata de violar os direitos dos administrados.

No tocante ao princípio da congruência, há que se fazer uma análise mais aprofundada. Das 5 decisões analisadas, em 4 não foi reconhecida a extrapetição, tendo a sentença sido mantida com base nos seguintes fundamentos: (i) proibição do enriquecimento ilícito da Administração; (ii) simplicidade da petição inicial trabalhista; (iii) adequação da natureza jurídica do pedido (o que se pode considerar uma variação do princípio iura novit curia); e (iv) matéria da condenação não é estranha à lide:

Na hipótese dos autos, ainda que haja sido acolhido o argumento de nulidade do contrato de trabalho, por ausência de concurso público, alegado em contestação, o Eg. Regional fundamentou a condenação no fato de que "o reclamante emprestou sua força de trabalho à ré de forma pessoal, com subordinação, em trabalho não eventual e oneroso, devendo o trabalho ser contraprestado, sob pena de enriquecimento ilícito da ré, o que é vedado pela lei pátria." (fl. 85) ${ }^{233}$.

$\mathrm{E}$

Correto o acórdão da Turma ao não conhecer do Recurso de Revista. Ao contrário do que afirma a Embargante, não houve julgamento extra petita, pois as parcelas deferidas pelo Tribunal Regional foram objeto do pedido sucessivo, formulado exatamente para a hipótese de não ser reconhecido vínculo empregatício diretamente com a Companhia Riograndense de Saneamento CORSAN.

$O$ fato de não ter sido formulada tese na petição inicial acerca de eventuais efeitos jurídicos do contrato nulo não afronta o art. 460 do CPC, pois, conforme bem ressaltado pela Turma, na sistemática do processo do trabalho, basta que a petição inicial contenha "uma breve exposição dos fatos de que resulte o dissídio", nos termos do art. 840, § 1. ${ }^{\circ}$, da CLT ${ }^{234}$.

E

A decisão 'extra petita' é aquela em que são excedidos os limites definidos pelos pedidos formulados pelos litigantes. Na espécie dos autos, o fato de a reclamada ter sido condenada à indenização substitutiva em face da nulidade do contrato, quando o pedido se refere ao reconhecimento do vínculo de emprego e pagamento de verbas remuneratórias e rescisórias, não constitui julgamento 'extra petita', pois não transborda dos limites do pedido, constatando-se que houve a redução dele e qualificação da natureza das parcelas.

(...)

O Tribunal Regional, ao analisar a demanda, apenas decidiu que, diante da nulidade do contrato de trabalho, as parcelas trabalhistas devidas ao reclamante seriam pagas na forma de indenização e não de salário. Ou seja, observou o pedido do reclamante, alterando apenas a natureza jurídica de tal pagamento em

\footnotetext{
${ }^{233}$ Ver Anexo 2, Decisão 7 - PROC. No TST-E-RR-553.807/99.4
}

${ }^{234}$ Ver Anexo 2, Decisão 95 - PROC. No TST-E-RR-616073/1999.6 
virtude do reconhecimento da nulidade contratual, por ausência de concurso público. Nada mais ${ }^{235}$.

Porém, em uma das decisões, cujo tema discutido é de igual teor, a SDI-1 considerou ilegal a condenação em verbas indenizatórias substitutivas se ausente pedido nesse sentido, julgando necessário que, ao menos, tal pleito tivesse sido feito de modo sucessivo:

Com efeito, é incontroverso que o reclamante postulou, expressamente, que fosse reconhecido que trabalhou como empregado do recorrido, e, conseqüentemente, se lhe assegurasse o direito a todas as parcelas de natureza trabalhista.

A decisão recorrida, sob o fundamento de que o pedido de reconhecimento de vínculo encontra óbice no art. 37, II, da Constituição Federal, rejeitou-o, mas concluiu que houve relação de trabalho, e, por essa razão, manteve a condenação ao pagamento de verbas salariais requeridas na inicial, mas a título de indenização.

Ora, o pedido, reconhecimento da relação de emprego e pagamento de verbas trabalhistas, definiu os limites da lide, e, por isso mesmo, impôs ao reclamado o ônus de se defender, atento, exclusivamente, à essa realidade jurídica.

Esclareça-se que o reclamante não formulou pedido sucessivo, ou seja, declaração de que trabalhou subordinadamente (relação de emprego), ou de relação de trabalho com seus consectários legais.

Inquestionável, pois, que foi ofendida a literalidade dos arts. 128 e 460 do CPC, visto que não era permitido condenar o reclamado a pagar as verbas indenizatórias, sob o fundamento de que houve relação de trabalho, porque esse não foi o pedido principal, e muito menos sucessivo ${ }^{236}$.

A divergência do teor das decisões - em um órgão cujo objetivo é "uniformizar a jurisprudência" - revela a delicadeza do tema ora estudado e a necessidade de que lhe seja dada mais atenção nos meios acadêmicos, de modo a evitar a possibilidade de decisões conflitantes como estas, que geram evidente insegurança jurídica e social. Embora se esteja defendendo a compatibilidade da flexibilização do princípio da congruência com o sistema processual brasileiro, é imperiosa uma mudança legislativa no sentido de esclarecer as hipóteses de permissibilidade de flexibilização ou desconsideração do princípio da congruência.

\subsubsection{Insalubridade}

Também foram identificadas decisões em que o direito material discutido diz respeito a questões ligadas à insalubridade e à periculosidade, tais como base de cálculo, reflexos salariais, grau e agente nocivo. Para o presente estudo são mais relevantes as que

\footnotetext{
${ }^{235}$ Ver Anexo 2, Decisão 85 PROC. No TST-E-ED-RR-466.152/1998

${ }^{236}$ Ver Anexo 2, Decisão 84 - PROC. No TST-E-RR-578.194/99.2
} 
versam sobre a possibilidade de o magistrado conceder adicional de insalubridade ou de periculosidade em grau diverso do pleiteado ou por ação de agente nocivo diferente do indicado na inicial.

Destaca-se, de início, que a questão do agente nocivo já foi devidamente contemplada pela súmula 293 do TST, que dispõe:

\begin{abstract}
ADICIONAL DE INSALUBRIDADE. CAUSA DE PEDIR. AGENTE NOCIVO DIVERSO DO APONTADO NA INICIAL. A verificação mediante perícia de prestação de serviços em condições nocivas, considerado agente insalubre diverso do apontado na inicial, não prejudica o pedido de adicional de insalubridade.
\end{abstract}

Deste modo, as duas decisões cujo objeto é justamente o grau de insalubridade ou o agente nocivo não consideraram haver violação ao princípio da congruência, por força do disposto na referida súmula ou sua aplicação analógica. Nota-se, ainda, que tais decisões tiveram como fundamento: (i) a necessidade de prova pericial para apuração da insalubridade; (ii) a busca da verdade real; e (iii) a impossibilidade de se exigir conhecimento técnico sobre tal assunto (uma leitura do princípio da simplicidade, pode-se considerar).

Consoante o disposto no $\S 2^{\circ}$ do art. 195 da CLT, o deferimento de adicional de insalubridade pressupõe, necessariamente a realização de perícia para o deferimento do adicional de insalubridade.

A exigência contida na lei busca justamente a determinação da verdade dos fatos alegados e a pertinência do pedido, razão por que o deferimento desse adicional em consonância com o laudo pericial produzido não implica infringência aos arts. 128 e 460 do CPC.

(...)

A observância dos limites da lide revela-se evidente, na medida em que deferido o adicional de insalubridade, que é o objeto do pedido, no grau apurado pela perícia.

(...)

É insubsistente a alegação de que o Autor não teria direito ao recebimento do adicional de insalubridade em grau máximo, constatado por laudo pericial, tendo em vista que na inicial requereu em grau diverso. Isto porque, não seria razoável exigir que o trabalhador ou seu advogado tivesse conhecimentos técnicos suficientes para apontar na exordial, com precisão, os elementos que classificavam (em grau mínimo, médio ou máximo) como insalubre o ambiente de trabalho.

Aplica-se, por analogia, o entendimento jurisprudencial desta Corte, consubstanciado na Súmula n ${ }^{\circ}$ 293/TST, no sentido de que o reconhecimento, por meio de perícia técnica, de agente nocivo diverso ao apontado na inicial, não prejudica o pedido de adicional de insalubridade ${ }^{237}$.

Destaca-se, neste item, a importância dada à busca da verdade real, um dos princípios basilares do Processo Trabalhista.

${ }^{237}$ Ver Anexo 2, Decisão 17 - PROC. No TST-E-RR-531160/1999.0 


\title{
4.3.3.7 Reconhecimento de Vínculo Empregatício e Anotação em CTPS
}

Por fim, não se podem deixar de analisar as decisões que versam sobre a menina dos olhos do Direito do Trabalho: o vínculo empregatício. Do total das 149 decisões analisadas, 6 dizem respeito ao reconhecimento de vínculo empregatício e 1 à condenação de anotação em CTPS, que guarda ainda a característica de ser a única decisão em que houve reconhecimento de existência julgamento ultra petita, mas foi mantida pelo TST.

Assim, o TST reconheceu não ter havido pedido expresso de anotação do contrato de trabalho em CTPS, mas afastou a pretensão de nulidade da decisão com fundamento nas seguintes teses: (i) pedido implícito; e (ii) aplicação do princípio da ultrapetição no Processo do Trabalho.

\begin{abstract}
A anotação do contrato de trabalho na Carteira de Trabalho e Previdência Social (CTPS) é obrigatória nos termos do art. 29 e seguintes da CLT e é a prova - juris tantum - da relação empregatícia. Assim, é corolário do reconhecimento do vínculo de emprego, sendo determinada pelo art. $39, \S 2^{\circ}$, da CLT.

Dessa forma, ainda que a ação trabalhista tenha como objeto apenas o pagamento de salários ou verbas rescisórias, o julgador deverá determinar a anotação do contrato de trabalho na CTPS, independentemente de pedido. (...)

Trata-se de aplicação do princípio da ultrapetição, segundo o qual o juiz pode conceder mais do que foi pedido ou coisa diversa daquela que foi pedida (Wagner D. Gigglio, Direito Processual do Trabalho, 13. ed., São Paulo: Saraiva, 2003, p. 75). O referido princípio tem encontrado guarida na nossa jurisprudência em casos excepcionais, como, por exemplo, no caso de estabilidade provisória e pedido de reintegração. A SBDI-1 pacificou o entendimento de que havendo pedido de reintegração, a concessão do salário relativo ao período de estabilidade já exaurido não constitui julgamento extra petita (Orientação Jurisprudencial 106). Outro exemplo é a Súmula 211 do TST, segundo a qual "os juros de mora e a correção monetária incluem-se na liquidação, ainda que omisso o pedido inicial ou a condenação". O fundamento adotado nas situações descritas pode também ser adotado para se entender que a anotação da relação de emprego na CTPS do reclamante é uma consequiência do seu reconhecimento que independe de pedido.

Com efeito, o reconhecimento do vínculo empregatício constitui fato gerador da obrigação de anotação da CTPS.

Não há falar, pois, em violação aos arts. $2^{\circ}$ e 128 do CPC, tendo em vista que a anotação da relação de emprego decorreu de observância de norma legal cogente. Os referidos dispositivos foram corretamente valorados pelo Tribunal Regional, que manteve a determinação de anotação do contrato de trabalho temporário na Carteira de Trabalho do reclamante.

Assim, não há falar em ofensa aos arts. 128 e 460 do CPC $^{238}$.
\end{abstract}

Em outro caso, objeto de decisão, a parte recorrente alegou a extrapetição com base na inexistência de pedido de vínculo empregatício. Tal pretensão foi afastada por todas as instâncias, sob o argumento de que, tendo o empregado formulado pedidos de

\footnotetext{
${ }^{238}$ Ver Anexo 2, Decisão 33 - PROC. No TST-E-RR-700079/2000.8. Grifos ausentes no original
} 
natureza trabalhista, desnecessária é a formulação de pedido de reconhecimento do vínculo:

(...) tendo-se presente que não se faz necessário pedido expresso de reconhecimento de vínculo de emprego, sobretudo quando evidenciado que todas as parcelas pleiteados obviamente só poderiam decorrer da existência de vínculo dessa natureza. Logo, não há falar em violação do disposto nos arts. 128 e 460 do CPC.

(...)

De outro lado, impossível visualizar a ofensa literal e direta aos artigos 128 e 460 do CPC. Isto porque o Reclamante, na qualidade de lavador de veículos de um posto de gasolina, postulou diversas verbas trabalhistas entre elas: verbas rescisórias, horas extras, adicional de insalubridade, adicional noturno, guias de seguro-desemprego, FGTS e a multa respectiva. Assim, sem que houvesse dúvidas acerca da relação de emprego entre as partes, os pedidos foram julgados procedentes. Salientando-se que, pelo fato de não existir nos autos contestação da Reclamada acerca da inexistência dos requisitos do contrato de trabalho, a relação de emprego tornou-se incontroversa. Assim, não se está a falar apenas do pedido, mas também dos fundamentos de fatos narrados pela parte, causa petendi remota. Na realidade, não havendo discussão acerca da natureza jurídica da relação havida entre as partes, desnecessário seria o requerimento expresso na petição inicial de reconhecimento de vínculo de emprego com a Reclamada ${ }^{239}$.

Os 4 acórdãos em que o reconhecimento de vínculo empregatício foi considerado pela parte recorrente como decisão além dos limites da lide têm, basicamente, o seguinte roteiro: o empregado propôs reclamação trabalhista em face da prestadora e da tomadora de serviços e, durante a instrução, foi verificada a fraude pela interposição ilegal de mão de obra ou pela terceirização de atividade-fim, reconhecendo-se o vínculo diretamente com a tomadora de serviços. Em três deles, tal decisão foi mantida, sob fundamentos que serão analisados mais à frente, e em um houve confirmação da reforma da decisão nesse sentido, por ter entendido a SDI-2 pela ofensa aos artigos 128 e 460 do CPC:

\footnotetext{
Ao contrário do afirmado pelo ora Recorrente, o pedido formulado na inicial do processo matriz não foi genérico, mas específico em relação à responsabilização subsidiária do terceiro Reclamado.

(...)

Logo, o pedido é claro, sendo desnecessária qualquer interpretação para se concluir que o pleito foi mesmo de condenação subsidiária do ora Recorrido.

(...)

Neste contexto, correta a decisão recorrida em que reconhecido o julgamento fora dos limites da lide, com violação dos arts. 128 e 460 do CPC $^{240}$.
}

Os outros 3 acórdãos, que entenderam pela legalidade desse tipo de decisão, merecem espaço próprio, uma vez que, embora tenham chegado à mesma conclusão, fizeram-no por caminhos ligeiramente diversos. No caso seguinte, a justificativa da

\footnotetext{
${ }^{239}$ Ver Anexo 2, Decisão 45 - PROC. N ${ }^{\circ}$ TST-ROAR-1.388/2003-000-04-00.5

${ }^{240}$ Ver Anexo 2, Decisão 148 - PROC. No TST-ROAR-35800-25.2007.5.18.0000
} 
manutenção da decisão foi a formulação de pedido amplo pelo empregado, em face de todos os reclamados:

Logo, faz-se necessário conferir se o pedido formulado na petição inicial foi efetivamente deferido fora dos limites fixados na reclamatória.

Verifica-se que, de fato, houve pedido de reconhecimento de vínculo empregatício formulado pelo reclamante, ora recorrente, em face de todos os integrantes do polo passivo daquela demanda.

Outrossim, depreende-se dos autos, à fl. 67, (petição inicial da Reclamação Trabalhista), item II DOS PEDIDOS, que logo na introdução o Reclamante “...PEDE sejam os Reclamados condenados nas parcelas a seguir destacadas ... fazendo-se constar, como primeiro pedido, na alínea "a", a ANOTAÇÃO NA CTPS DO AUTOR ..." (sem destaques no original).

(...)

Dessa forma, a condenação atribuída às partes, em consonância e em atendimento a pedido constante da petição inicial, dentro dos limites postos, não autoriza, por si só, a rescisão do julgado, com base em alegação de julgamento extra ou ultra petita.

$\mathrm{E}$, in casu, a sentença rescindenda não se afastou dos limites da lide, mas, ao contrário, decorreu da interpretação dada pelo julgador aos pedidos veiculados na petição inicial, cotejados com as provas dos autos, não se podendo concluir que tenha havido ofensa direta e frontal aos dispositivos de lei retrocitados, até porque foi requerida a condenação de todos os reclamados nas obrigações de fazer e dar, propostas na exordial ${ }^{241}$.

Não obstante o acerto de tal decisão, que também levou em conta a produção de provas durante o processo e o livre convencimento do juiz, há que se reconhecer que a formulação do pedido do autor fugiu à melhor técnica processual., ou pelo menos, à técnica prevista no CPC, que exige que o pedido seja certo e determinado e que admite apenas a cumulação de pedidos compatíveis entre si: a leitura da decisão revela que havia sido formulado pedido de responsabilização subsidiária da empresa recorrente. A não ser que tal pedido tenha sido feito de modo sucessivo, deve-se admitir que é incompatível com o pleito de reconhecimento de vínculo empregatício, de modo que se pode concluir que, neste caso, a falta de técnica do patrono do autor o favoreceu. Nota-se, ainda, que a justificativa do "pedido amplo" para afastar a nulidade de sentença por violação ao princípio da congruência foi utilizada em mais 3 oportunidades, apesar dos ditames legais acerca da necessidade de certeza e determinação deste elemento da petição inicial.

Em outra oportunidade, o TST manteve a decisão que reconheceu o liame empregatício com fundamento no princípio do livre convencimento do juiz e no princípio da realidade:

Como se vê, tais artigos [128 e 460, CPC] tratam da ocorrência do julgamento "extra petita", o que, "in casu", não ocorreu. Isso porque, mesmo diante do pedido de responsabilização subsidiária do Recorrido, o juiz prolator da decisão

\footnotetext{
${ }^{241}$ Ver Anexo 2, Decisão 143 - PROC. No TST-ROAR-366/2007-000-18-00.5 Grifos no original.
} 
rescindenda, por meio da instrução dos autos, concluiu que o verdadeiro empregador era o $3^{\circ}$ Reclamado.

(...)

Nesse contexto foram observados os limites da "litiscontestatio", e perquirir a razoabilidade da interpretação dos elementos de fato constantes dos autos, que concluiu pela existência do vínculo empregatício com o Recorrido, não induz à rescisão do julgado, nos termos do art. 485 , V, do CPC, em razão do óbice da Súmula 410 do TST, segundo a qual "A ação rescisória calcada em violação de lei não admite reexame de fatos e provas do processo que originou a decisão rescindenda",242.

A última decisão, na esteira da anterior, permitiu o reconhecimento diretamente com o tomador de serviços baseando-se no princípio do livre convencimento do juiz. Contudo, sustentou que o magistrado, ao reconhecer a fraude e aplicar o disposto no inciso I da súmula 331 do TST, não extrapolou os limites da lide, mas apenas "ajustou o pólo passivo" da reclamação!

(...) pois o fato de o autor haver pleiteado o reconhecimento do vínculo com a Cooperativa de Apoio ao Trabalhador do Transporte e a condenação solidária da Goodyear, não inibe o livre convencimento do Magistrado que, mediante a prova dos autos, conclui pela existência de intermediação fraudulenta de mão-de-obra, por meio de cooperativa, conduzindo a um julgamento que, ao contrário do alegado pela Goodyear, não foge dos limites traçados pelo reclamante, mas apenas se ajusta à relação jurídica existente.

A relação obrigacional que caracteriza a solidariedade passiva implica a coresponsabilidade dos devedores, daí porque, de acordo com o artigo 175 do $\mathrm{CCB}$, "O credor tem direito a exigir e receber de um ou de alguns dos devedores, parcial ou totalmente, a dívida comum; se o pagamento tiver sido parcial, todos os demais devedores continuam obrigados solidariamente pelo resto". No entanto, no caso dos autos, conforme já foi exposto, a Cooperativa não passava de mera intermediadora de mão-de-obra, ficando comprovado pela prova produzida que o vínculo empregatício formou-se com a tomadora dos serviços Goodyear. Assim, apesar de o reclamante haver pleiteado a condenação solidária da Goodyear, as provas conduziram o Julgador a quo pela inexistência da solidariedade entre as partes.

Destarte, o que ocorreu na situação específica dos autos foi que o Julgador a quo, nos limites do que foi exposto e postulado na inicial e de tudo que foi devidamente provado, deferiu o pedido do autor, qual seja, reconhecimento do vínculo e o pagamento das verbas decorrentes da relação de emprego, porém, ajustando-se o pólo passivo em face da fraude na intermediação de mão-de-obra, uma vez que demonstrada a existência de vínculo de emprego diretamente com o tomador dos serviços ${ }^{243}$.

Há que se reconhecer que tal decisão é um exemplo perfeito do reconhecimento da ordem pública da norma trabalhista e do interesse público da inibição de condutas fraudulentas.

${ }^{242}$ Ver Anexo 2, Decisão 59 - PROC. No TST-ROAR-359/2007-000-18-00.3
${ }^{243}$ Ver Anexo 2, Decisão 69 - PROC. No TST-E-RR-664.409/2000.9 


\subsubsection{Flexibilização do Princípio da Congruência em Relação ao Pedido e à Causa de Pedir}

Uma vez estudados os temas de Direito Material mais frequentes na pesquisa, aprofundar-se-á a análise dos acórdãos no tocante à argumentação utilizada para justificar o conhecimento, pelo magistrado, de pedido ou causa de pedir não expressos na petição inicial.

\subsubsection{Iura Novit Curia ou Da Mihi Factum, Dabo Tibi Ius}

Os brocardos latinos, já estudados, aparecem expressamente em dezesseis decisões para justificar a manutenção de decisão aparentemente destoante do pleiteado na petição inicial. Ressalta-se, ainda, que o espírito de tais princípios também pode ser encontrado nas duas decisões que utilizaram a expressão "adequação jurídica do pedido".

Identificaram-se três modos de aplicação do Iura Novit Curia e do Da Mihi Factum, Dabo Tibi Ius nas decisões analisadas: (i) deferimento de pedido com fundamento legal não indicado pela parte; (ii) deferimento de pedido não expressamente formulado por força da norma aplicável; e (iii) conhecimento de ação rescisória por fundamento legal diferente do indicado na inicial.

No caso abaixo, o TST manteve decisão que conhecera da pretensão do reclamante com base em fundamento legal diferente do indicado. De outro modo não poderia ser, já que, se nem mesmo o CPC exige tal indicação, não poderia o Processo do Trabalho, dirigido pelo princípio da simplicidade, impor tal ônus às partes.

\footnotetext{
Para tanto, as instâncias ordinárias analisaram os fatos, tais como narrados na petição inicial, e a estes aplicaram o dispositivo legal reputado pertinente (no caso, o art. 118, da Lei $\mathrm{n}^{\circ}$ 8.213/91), reputando impertinente o fundamento jurídico de que se valeu o Reclamante na petição inicial (art. 93, do mesmo diploma legal).

Veja-se, pois, que não houve, em momento algum, extrapolação dos limites da controvérsia, na medida em que o pedido formulado pelo Autor foi devidamente acolhido, ainda que sob fundamento jurídico diverso do sustentado na petição inicial.

Sucede que os arts. 128 e 460, do CPC vedam apenas o julgamento fora do pedido, mas não impedem o acolhimento do pedido com base em distinta causa de pedir, pois, como bem ressaltou a Eg. Turma, ao juiz cabe aplicar aos fatos o direito que considerar disciplinador da matéria, conforme os princípios "iura novit curia" e "da mihi factum, dabo tibi ius" 244.
}

${ }^{244}$ Ver Anexo 2, Decisão 71 - PROC. No TST-E-RR-640.811/00.6 
Em outra decisão, o TST entendeu ser lícita a decisão do magistrado que condenou a empresa à integração na base de cálculo das horas extras de todas as parcelas salariais, embora o reclamante tenha apenas indicado duas parcelas com tal natureza:

\begin{abstract}
O simples fato de o reclamante, após ter pedido a integração de todas as parcelas salariais no cálculo das horas extras, indicar, exemplificativamente, algumas verbas de cunho salarial que entenda deva compor a referida base de cálculo não desnatura o amplo pedido formulado anteriormente e não restringe a atuação do juiz, a quem compete definir, observado o pedido inicial, quais parcelas possuem ou não natureza salarial, em respeito ao princípio iura novit curia ${ }^{245}$.
\end{abstract}

De modo semelhante, foi mantida sentença que condenou a empresa ao depósito das parcelas devidas ao FGTS com base em pedido de "pagamento de FGTS":

\begin{abstract}
O Regional rejeitou a preliminar de julgamento extra petita, sob o fundamento de que "o Juiz apenas adequou o pedido inicial à lei existente segundo o princípio da mihi factum, dabo tibi jus, determinando, segundo o disposto na Lei 8.036/90, o depósito do FGTS" (fl. 163).

Sustenta o recorrente que a decisão afrontou o artigo 460 do CPC, visto que os reclamantes postularam o pagamento das parcelas do FGTS e não os depósitos das mesmas. Por isso, entende que os reclamantes pretendiam obter o pagamento das parcelas já depositadas do FGTS e não a complementação dos depósitos não efetuados.

(...)

Comunga-se com a decisão proferida na instância ordinária, no sentido de que cabia ao julgador subsumir da descrição dos fatos o direito aplicável, segundo a máxima da mihi factum, dabo tibi jus. Acrescente-se, em reforço à referida tese, a incidência do princípio da simplicidade, que informa o Processo do Trabalho. Nesse contexto, a aplicação das normas do processo civil deve ser mitigada ${ }^{246}$.
\end{abstract}

Por fim, tem-se decisão acerca da possibilidade de conhecimento de ação rescisória que indicou erroneamente o seu fundamento legal:

É pertinente esclarecer que apesar de a pretensão rescisória ter sido formulada
com menção tão-somente ao inciso II do artigo 485 do CPC, na petição inicial,
os Autores afirmaram que foram coagidos pela Empresa a propor reclamação
trabalhista, outorgar poderes a advogados indicados pela Empresa e a realizar
acordo judicial.
Considerando os fatos e fundamentos invocados como causa de pedir, verifica-se
que, no presente caso, é possível fazer a adequada qualificação jurídica e
examinar a rescisória à luz do inciso VIII do artigo 485 do CPC, por força do
princípio iura novit curia ${ }^{247}$.

Tal decisão tem especial interesse, pois se coaduna com o entendimento firmado na Súmula 408 do TST:

Não padece de inépcia a petição inicial de ação rescisória apenas porque omite a subsunção do fundamento de rescindibilidade no art. 485 do CPC ou o capitula erroneamente em um de seus incisos. Contanto que não se afaste dos fatos e

\footnotetext{
${ }^{245}$ Ver Anexo 2, Decisão 10 - PROC. No TST-E-RR-804.316/2001.7 Grifos no original.

${ }^{246}$ Ver Anexo 2, Decisão 108 - PROC. N ${ }^{\circ}$ TST-E-RR-795527/2001.0

${ }^{247}$ Ver Anexo 2, Decisão 127 - PROC. No TST-ROAR-99697/2003-900-04-00.0
} 
fundamentos invocados como causa de pedir, ao Tribunal é lícito emprestar-lhes a adequada qualificação jurídica ("iura novit curia"). No entanto, fundando-se a ação rescisória no art. 485, inc. V, do CPC, é indispensável expressa indicação, na petição inicial da ação rescisória, do dispositivo legal violado, por se tratar de causa de pedir da rescisória, não se aplicando, no caso, o princípio "iura novit curia".

A súmula supracitada traz uma interessante observação: à ação rescisória se aplica o genericamente aplicável às petições iniciais, ou seja, a dispensa de fundamentação legal, salvo quando se tratar de alegação de que a decisão rescindenda violou de modo literal disposição de lei (artigo 485, V, do CPC). Na realidade, o que a súmula proíbe é que o magistrado julgue procedente rescisória por violação a dispositivo legal diferente do indicado: neste caso, a indicação do dispositivo legal violado equipara-se à fundamentação fática da rescisória!

\subsubsection{Decorrência Lógica do Pedido}

A ideia de decorrência lógica do pedido está intimamente ligada à dos princípios estudados no item anterior, pois, ao considerar que o reclamante, elaborando determinado pedido x, também deseja y, sendo y a decorrência legal de $\mathrm{x}$, não está o juiz fazendo nada mais do que dar à norma de Direito Material total efetividade. Tal relação fica clara na decisão em que o TST manteve entendimento anterior no sentido de que o pagamento de adicionais é decorrência lógica do pedido de pagamento de horas extras, não sendo necessária sua formulação: "Por outro lado, o deferimento de adicional de horas extras não constitui julgamento ultra petita, porquanto, se houve pedido de horas extras, é consequência natural a adoção de um percentual para que se torne possível o cálculo dessas horas" $" 248$.

$\mathrm{Na}$ decisão anterior tem-se uma relação de acessoriedade entre as horas extras e o adicional, mas a decorrência lógica do pedido pode fazer o caminho inverso. Em outro acórdão, o TST manteve decisão que dispensou a formulação de pedido de reconhecimento de vínculo empregatício ante o pleito de verbas de natureza salarial:

De outro lado, impossível visualizar a ofensa literal e direta aos artigos 128 e 460 do CPC. Isto porque o Reclamante, na qualidade de lavador de veículos de um posto de gasolina, postulou diversas verbas trabalhistas entre elas: verbas rescisórias, horas extras, adicional de insalubridade, adicional noturno, guias de seguro-desemprego, FGTS e a multa respectiva. Assim, sem que houvesse dúvidas acerca da relação de emprego entre as partes, os pedidos foram julgados procedentes. Salientando-se que, pelo fato de não existir nos autos contestação

\footnotetext{
${ }^{248}$ Ver Anexo 2, Decisão 34 - PROC. No TST-E-RR-568.232/1999.6
} 
da Reclamada acerca da inexistência dos requisitos do contrato de trabalho, a relação de emprego tornou-se incontroversa. Assim, não se está a falar apenas do pedido, mas também dos fundamentos de fatos narrados pela parte, causa petendi remota. $\mathrm{Na}$ realidade, não havendo discussão acerca da natureza jurídica da relação havida entre as partes, desnecessário seria o requerimento expresso na petição inicial de reconhecimento de vínculo de emprego com a Reclamada ${ }^{249}$.

No mesmo sentido, tem-se o reconhecimento de dispensa indireta, inobstante o pedido expresso, em decorrência dos pedidos feitos:

A reclamada, em seu recurso de revista, alegou que o Tribunal Regional, ao deferir o pagamento das verbas rescisórias, afastando o reconhecimento da justa causa, incidiu em violação dos artigos 128 e 460 do CPC e $5^{\circ}$, incisos LIV e LV, da Constituição da República. Asseverou que não se descortinava, da inicial da reclamatória, qualquer pedido da reclamante no sentido de se converter a justa causa imposta em rescisão imotivada.

(...)

Da mesma forma, distingue-se, dentre os pedidos formulados na peça de ingresso, o de condenação das reclamadas no pagamento das verbas rescisórias, aviso prévio de 30 dias, férias vencidas e proporcionais, $13^{\circ}$ salário e $13^{\circ}$ proporcional - todas parcelas que só seriam exigíveis mediante a conversão da dispensa por justa causa em dispensa imotivada ${ }^{250}$.

Por fim, destaca-se decisão em que a determinação da decorrência lógica do pedido claramente se baseia em uma interpretação sistemática da petição inicial, posto que o magistrado utilizou-se de elementos constantes apenas da causa de pedir - e ausentes no pedido - para deferir não apenas a liberação dos valores depositados no FGTS, mas também a correção dos depósitos efetuados a menor:

Na inicial da reclamação trabalhista a causa de pedir está relacionada com o nãofornecimento das guias dos Termos de Rescisão de Contrato de Trabalho dos reclamantes, o que impediu o levantamento dos valores relativos aos depósitos do FGTS. Naquela mesma oportunidade, os reclamantes destacaram que tais quantias, apesar de terem sido recolhidas a menor, vinham sendo regularmente recompostas, em face de acordo celebrado pelo Município de Coronel Ezequiel perante a Caixa Econômica Federal - CEF.

Neste passo, no pedido formulado na reclamação trabalhista de liberação dos valores relativos ao FGTS que se encontravam depositados na CEF, conforme disposto no item 2.1 da inicial: "Que se digne Vossa Excelência determinar, através do competente alvará, a liberação para os autores, junto a CEF - Caixa Econômica agência de Santa Cruz/RN dos valores relativos ao FGTS dos mesmos e que lá se encontram depositados" (fls. 12), está compreendida, por corolário lógico, a pretensão acessória de depósitos corretos e integralmente efetuados, de acordo com as disposições legais incidentes.

$\mathrm{O}$ artigo 460 do CPC estabelece que é defeso ao juiz "proferir sentença, a favor do autor, de natureza diversa da pedida, bem como condenar o réu em quantidade superior ou em objeto diverso do que lhe foi demandado". Extrai-se que ao magistrado é vedado afastar-se do pedido e da causa de pedir exposta na inicial. No presente caso, entretanto, foi expressamente informado pelos reclamantes na inicial da reclamação trabalhista que o Município estava regularizando as quantias devidas a título de depósitos do FGTS, por força do pactuado no Termo de Compromisso firmado com a CEF, pelo que, a responsabilidade do

${ }^{249}$ Ver Anexo 2, Decisão 45 - PROC. No TST-ROAR-1.388/2003-000-04-00.5
${ }^{250}$ Ver Anexo 2, Decisão 4 - PROC. No TST-E-RR-644.881/2000.3 
Município, como declarada pela MM. Vara do Trabalho de Currais Novos e confirmada pelo TRT da $21^{\mathrm{a}}$ Região, pela correção dos depósitos, foi decidida dentro dos limites em que a lide foi proposta, o que não demonstra a hipótese de julgamento além da litiscontestatio. Incólume, pois, o disposto nos artigos 459 e 460 do $\mathrm{CPC}^{251}$.

\subsubsection{3 “Quem Pede Mais, Pede Menos"}

Como já abordado quando se tratou da condenação em responsabilidade subsidiária, com base em pedido de responsabilidade solidária, a ideia do "quem pede mais, pede menos" vai ao encontro do entendimento proposto no início do Capítulo 3 acerca do significado da expressão "julgamento nos limites da lide", que não deve ser compreendida como uma limitação do juiz à literalidade do pedido, mas a tudo o que esse pedido pode conter.

Em um dos acórdãos analisados, fica claro o entendimento de que a condenação menos gravosa não implica violação ao princípio da congruência:

REMESSA EX OFFICIO E RECURSO ORDINÁRIO EM AÇÃO RESCISÓRIA. JULGAMENTO EXTRA PETITA. RESPONSABILIDADE SUBSIDIÁRIA DO TOMADOR DE SERVIÇO. ADMINISTRAÇÃO PÚBLICA. VIOLAÇÃO DE LEI (ARTS. 128 E 460 DO CPC). NÃOCONFIGURAÇÃO. Havendo na petição inicial da Reclamação Trabalhista pedido de reconhecimento de vínculo empregatício diretamente com o Autor da presente Rescisória e condenação solidária das Reclamadas, não há como conferir a existência de julgamento fora da litiscontestatio. A responsabilidade solidária, por ser mais ampla, engloba a subsidiária de menor prejuízo ao demandado. Não se trata, portanto, de matéria estranha à lide, não ficando demonstrada a hipótese de que o acórdão rescindendo decidiu fora dos fundamentos da causa de pedir, permanecendo, pois, intactos os arts. 128 e 460 do $\mathrm{CPC}^{252}$.

Em outra decisão, a empresa alegou violação aos artigos 128 e 460 da CLT por ter o magistrado condenado ao pagamento de minutos residuais com base em pagamento em horas extras. Por vezes, é necessário o pronunciamento de uma das mais altas Cortes do país para dizer o óbvio: que os minutos estão compreendidos nas horas...

\footnotetext{
Com efeito, constatada a existência de pleito de pagamento de horas extras na peça inaugural (fls. 02-5), e verificada pelas instâncias ordinárias, à luz da prova produzida, a ocorrência de variações de horário do registro de ponto ensejadoras do pagamento de minutos residuais, não há falar que o respectivo deferimento tenha implicado exorbitância dos limites da lide. Por certo que abarcados, no pedido de pagamento de horas extras, os minutos que antecedem e sucedem a jornada de trabalho ${ }^{253}$.
}

Muito próximo dessa ideia, está a de "pedido implícito", a ser analisada a seguir.

\footnotetext{
${ }^{251}$ Ver Anexo 2, Decisão 142 - PROC. N ${ }^{\circ}$ TST-RXOFROAR-1.485/2002-000-21-00.4

${ }^{252}$ Ver Anexo 2, Decisão 40 - PROC. N ${ }^{\circ}$ TST-RXOFROAR-801086/2001.3

${ }^{253}$ Ver Anexo 2, Decisão 107 - PROC. No TST-E-RR-119/1996-029-15-00.3
} 


\subsubsection{Pedido Implícito}

Embora seja frequente na doutrina a alusão ao "pedido implícito", não foram encontradas muitas referências expressas a esse termo na pesquisa jurisprudencial, sendo certo que a sua similaridade com a noção de "decorrência lógica do pedido" e o "quem pede mais, pede menos", pode ter levado o tribunal a preferir estas justificativas àquela, tendo em vista a já discutida incorreção técnica de tal termo.

Destaca-se acórdão em que houve a aplicação exemplar da súmula 396, justificada pela ideia de pedido implícito:

Com efeito, o pedido de reintegração, assim como bem entendeu a v. decisão recorrida, já traz implícito o pagamento do período de afastamento do empregado. Isto porque, a reintegração refere-se à hipótese em que se dá a continuidade do contrato, inclusive com o pagamento da remuneração por todo o período de afastamento. Logo, a concessão dos salários do período de afastamento, compreendido entre a rescisão e o retorno ao posto de serviço, está contida no próprio conceito de reintegração ${ }^{254}$.

\subsubsection{Livre Convencimento do Juiz}

O livre convencimento do juiz é corolário do Processo Moderno cuja aplicação evita a valoração prévia das provas e deixa a cargo do juiz perceber as sutilezas que são típicas dos relacionamentos humanos. Das oito decisões encontradas, três dizem respeito a horas extras; duas, a responsabilidade de tomador de serviços; uma versa sobre rescisão contratual; uma trata de reintegração no emprego; e, por fim, uma diz respeito a vínculo empregatício. A fim de se evitarem repetições, foram selecionados dois acórdãos em que o uso da prerrogativa do livre convencimento do juiz importou em condenação da empresa em termos diversos do expressamente pedido na inicial.

Assim, neste primeiro caso, foi mantida decisão que reconheceu a jornada de trabalho de 40 horas semanais e condenou a empresa ao pagamento de horas extras além da $40^{\mathrm{a}}$ trabalhada na semana, embora o pedido inicial tenha sido formulado com base em uma jornada de 44 horas semanais:

Ressalte-se ainda que a fixação da jornada de trabalho em quarenta horas semanais levou em conta os horários indicados tanto na inicial como na defesa e as informações obtidas a partir dos testemunhos colhidos em audiência, uma vez que não foi possível precisar de início os efetivos horários de entrada e saída da reclamante, ante as inconsistências encontradas na prova documental (cartões de

\footnotetext{
${ }^{254}$ Ver Anexo 2, Decisão 133 - PROC. No TST-RXOF e ROAR-169.606/2006-900-01-00.3
} 
ponto contendo registros uniformes) em relação à realidade contextualizada nos autos originários, razão de ter sido infirmada pela prova testemunhal (Súmula $n^{\circ}$ 338/TST).

(...)

Ora, nada impede que o julgador, lastreado no conteúdo fático-probatório extraído dos autos, fixe a jornada contratual e daí conceda o pagamento das horas extraordinárias habitualmente prestadas. A decisão rescindenda, em assim entendendo, expressou seu livre convencimento motivado. Em conseqüência, deu a exata subsunção ao conceito contido no art. 131 do CPC, visto que sua conclusão decorreu da aplicação do princípio da persuasão racional. A apreciação e valoração das provas é livre, bastando que o Juiz atenda aos fatos e circunstâncias constantes dos autos e indique os motivos que lhe formaram o convencimento, o que, efetivamente, ocorreu no presente caso ${ }^{255}$.

Em outro acórdão, entendeu-se legal a decisão que, com base nas provas produzidas, decidiu pela existência de dispensa sem justa causa, não obstante o pedido do autor tenha sido o reconhecimento de nulidade de pedido de demissão e dispensa indireta:

Frise-se que, se o juiz ao decidir a causa levou em conta, na sua motivação, que o pedido de demissão não atendeu requisitos previstos em lei que elidia o fundamento alegado pela Reclamada e, enquadrando-o no ordenamento jurídico concluiu que o caso concreto era de demissão sem justa causa, assim o fez com respaldo na lei (CPC, art. 131), ou seja, apreciou livremente a prova, atendendo aos fatos e circunstâncias constantes dos autos, ainda que não alegados pelas partes, declinando os motivos que lhe formaram o convencimento, não havendo como se admitir que foram extrapolados os limites objetivos da lide, permanecendo, pois, intactos os preceitos de lei tidos por violados pela Recorrente.

Assim, se houve pedido de reconhecimento de rescisão indireta, a conclusão de dispensa sem justa causa apenas demonstra que o julgador observou o princípio do livre convencimento motivado (CPC, art. 131), aplicando as normas legais pertinentes ao caso concreto ${ }^{256}$.

Este caso traz, ainda, outra razão para a rejeição da alegação de violação ao princípio da congruência, que é a inexistência de nulidade se não há prejuízo (pas de nullité sans grief):

As verbas rescisórias decorrentes dessa forma de resolução contratual são as mesmas da hipótese de rescisão indireta requerida pela então Reclamante, não havendo prejuízo algum à Empresa-reclamada, o que demonstra perfeitamente que houve decisão dentro dos limites da litiscontestatio delimitados pelas $\operatorname{partes}^{257}$.

\subsubsection{Simplicidade do Processo do Trabalho}

Por vezes esquecida por advogados e magistrados, a simplicidade do Processo do Trabalho não deve ser apenas considerada uma característica histórica, mas sim um

\footnotetext{
${ }^{255}$ Ver Anexo 2, Decisão 53 - PROC. No TST-ROAR-953/2002-000-03-00.1

${ }^{256}$ Ver Anexo 2, Decisão 47 - PROC. No TST-ED-ROAR-310/2006-000-12-00.2

${ }^{257}$ Idem.
} 
elemento axiológico quando da avaliação dos pedidos constantes da petição inicial. Em 5 acórdãos, o TST interpretou a simplicidade do processo de modo favorável ao empregado, mantendo decisões que deferiram pedidos não formulados expressamente.

Deste modo, foi mantida decisão que condenou a empresa ao pagamento dos reflexos salariais devidos em razão do pagamento de adicional de insalubridade, não obstante a inexistência de pedido específico nesse sentido:

Conforme asseverado pela Turma, o reclamante, na petição inicial, pediu a
condenação da reclamada ao pagamento "da insalubridade, integrando as
cominaçôes legais".
Dessarte, está claro que na petição inicial o reclamante pretendeu a condenação
da reclamada ao pagamento do adicional de insalubridade e o reflexo dele no
cálculo das demais parcelas em que a lei determina essa integração.
Logo, não há falar em julgamento extra petita, uma vez que não foi proferida
sentença de natureza diversa da pedida, nem há condenação em quantidade
superior ou em objeto diverso do que foi pleiteado.
Saliente-se que, em face do princípio da simplicidade que informa o processo do
trabalho, os requisitos da petição inicial, previstos no art. 840 da CLT, não
observam o rigorismo e as formalidades das normas de processo civil, que têm a
sua aplicação subsidiária mitigada nessa hipótese ${ }^{258}$.

Em decisão já exposta ${ }^{259}$ quando foram discutidos os acórdãos referentes a salário, também há referência ao princípio da simplicidade, sob a argumentação de que no Processo do Trabalho ainda prevalece o ius postulandi, embora naquele caso não houvesse notícia do uso de tal prerrogativa, cada vez mais raro. Contudo, na pesquisa realizada foi identificada uma preciosidade: a manutenção de uma decisão proferida em um processo iniciado pelo ius postulandi que determinou o desconto das contribuições previdenciárias, apesar de a reclamante não ter formulado tal pedido.

Cumpre ainda registrar que, na hipótese dos autos, a reclamação foi apresentada na forma verbal.

Verifica-se à fl. 13 que a Obreira, ora Recorrida, compareceu pessoalmente perante a Vara do Trabalho de Vilhena, para reclamar direitos trabalhistas em desfavor do Estado de Rondônia. Naquele momento, tal manifestação foi reduzida a termo pela Diretora de Secretaria, na forma do artigo 839, alínea "a", e $840, \S 2^{\circ}$, da CLT.

O pedido foi verbal, fazendo-se formalizar mediante um Termo de Reclamação, que sequer foi redigido pela Obreira, eis que no local da sua assinatura apenas constou a sua impressão digital.

Em face do jus postulandi, que permite os trabalhadores reclamarem pessoalmente perante a justiça do trabalho e acompanhar as suas reclamações até o final (artigo 791 da CLT), a exigência de requisitos mínimos como, por exemplo, o pedido, deve ser visto com certo cautela, sem maiores rigores, haja vista que nos procedimentos trabalhistas prevalece o princípio da simplicidade e do não-formalismo.

Isso, porque o artigo 840 da CLT, por intermédio dos seus parágrafos, quando se refere à reclamação verbal, apenas estabelece que a reclamação verbal "será

${ }^{258}$ Ver Anexo 2, Decisão 20 - PROC. N No TST-E-RR-554.037/1999.0
${ }^{259}$ Ver Anexo 2, Decisão 1- PROC. N ${ }^{\circ}$ TST-E-RR-469.561/98.3 
reduzida a termo, em duas vias datadas e assinadas pelo escrivão ou chefe da Secretaria, observado, no que couber, o disposto no parágrafo anterior" (destaquei). Tal parágrafo fixa os requisitos mínimos a serem observados na reclamação escrita, quais sejam, "designação do presidente da Vara, ou do juiz de Direito, a quem for dirigida, a qualificação do Reclamante e do Reclamado, uma breve exposição dos fatos de que resulte o dissídio, o pedido, a data e a assinatura do reclamante ou de seu representante".

O próprio legislador afirma que a reclamação verbal observará "no que couber" a reclamação escrita. Assim, tratando-se de reclamação verbal, requerida por trabalhador que sequer redigiu o Termo de Reclamação e muito menos esteve assistido por advogado, a rigor, não se há falar em petição inicial e muito menos em julgamento extra petita.

Não havendo fundamento para constatar a existência de julgamento extra petita, nego provimento ao Apelo ${ }^{260}$.

Trata-se de uma verdadeira lição sobre a atuação judicial diante da reclamação trabalhista formulada verbalmente.

\subsubsection{Norma de Ordem Pública}

Embora sempre destacado no estudo doutrinário do Direito Material Trabalhista, seu caráter de norma de ordem pública não foi utilizado pelo TST com a frequência que se poderia esperar para justificar eventuais flexibilizações do princípio da congruência. Foram identificadas 4 decisões que utilizaram tal argumento, sendo que uma dela é justamente a anteriormente citada:

Ainda que assim não fosse [que não tivesse sido identificado obstáculo para apreciação do pedido rescisório com base na súmula 298, TST], tratando-se de matéria de ordem pública, é dever da autoridade judiciária determinar os descontos previdenciários ${ }^{261}$.

Em outra decisão, o TST rejeitou recurso da parte que alegou extrapetição de decisão judicial que determinou o envio de ofício às autoridades competentes para a apuração de irregularidades cometidas, baseando-se na mais pública das normas, qual seja a Constituição Federal:

Não se visualiza a propalada ofensa aos arts. $5^{\circ}$, inciso XXXIX, da Lei Maior, 128 e 460 do CPC, uma vez que os arts. 653, f, e 680, g, da CLT, conferem ao juiz do trabalho atribuições administrativas de interesse da Justiça do Trabalho.

A determinação de expedição de ofício, mesmo não requerida, não conduz à idéia de julgamento extra petita, pois está escorada na autoridade do magistrado como agente político do Estado, cabendo aos órgãos destinatários dos ofícios deliberar sobre as providências cabíveis.

O Estado brasileiro é uno, sendo tripartite a divisão dos poderes soberanos (art. $2^{\circ}$, da Constituição Federal), dos quais o jurisdicional concretizado no EstadoJuiz, é um poder-dever do qual o magistrado não pode eximir-se, tendo desdobramentos tanto na sua esfera jurisdicional como na administrativa, não

\footnotetext{
${ }^{260}$ Ver Anexo 2, Decisão 124 - PROC. N ${ }^{\circ}$ TST-RXOF e ROAR-12676/2003-000-14-00.0 Grifos no original. ${ }^{261}$ Idem.
} 
obstante o mister principal seja traduzido no poder de dizer o direito. É o que entende José Afonso da Silva quando trata do sistema de freios e contrapesos no qual os poderes Legislativo, Executivo e Judiciário, a par de uma função específica, exercem incidentalmente e de forma restrita facetas dos outros poderes da União.

Não pode o Judiciário abster-se de facilitar a apuração de irregularidades administrativas, in casu, expedição de ofícios ao Tribunal de Contas e ao Ministério Público estaduais, órgãos que entende competentes, para fins de apuração de irregularidades, porquanto é o Estado, na sua forma jurisdicional, informando ao Estado, na sua forma executiva, de que tais ilícitos ocorreram.

A competência contida no artigo 114, da Lex Legum, não causa óbice algum ao determinado, porquanto a questão está afeta ao âmbito administrativo ${ }^{262}$.

Trata-se de uma bela decisão, na qual não apenas se reafirmou a amplitude dos poderes do juiz, mas também a responsabilidade do Judiciário no equilíbrio dos três Poderes - especialmente se se considerar que a empresa reclamada neste caso faz parte da administração indireta do Estado de São Paulo. Assim, a decisão judicial no sentido de determinar o envio não apenas não é nula, como também é imperativa, sendo que o silêncio sobre tais irregularidades importa em omissão do magistrado e - por que não? em decisão citra petita.

Em outro acórdão em que se identifica o caráter público da norma discutida, não foi reformada a decisão que condenou a empresa ao pagamento de adicional de insalubridade em percentual superior ao pleiteado:

Ademais, a Constituição a Constituição da República, em seu artigo $7^{\circ}$, inciso
XXVIII, prevê o 'adicional de remuneração para as atividades penosas,
insalubres ou perigosas', como um dos direitos sociais dos trabalhadores urbanos
e rurais.
O supracitado dispositivo constitucional, por visar à proteção da saúde do
trabalhador, é dotado de caráter de ordem pública, o que implica, por
decorrência, a não-configuração do julgamento extra ou ultra petita, com a
concessão de adicional superior ao pretendido na inicial ${ }^{263}$.

A contrario sensu, o TST julgou procedente ação rescisória sobre decisão de tribunal regional que conheceu do tema "horas extras", embora tal matéria não tivesse sido expressamente devolvida ao segundo grau:

Dessa forma, tem-se que o tema relacionado às horas extras, não se tratando de questão de ordem pública, não foi devolvido ao Tribunal Regional do Trabalho da $2^{\text {a }}$ Região, razão pela qual em atenção ao princípio tantum devolutum quantum appellatum, de que trata o artigo 515 do $\mathrm{CPC}$, merece acolhimento a pretensão rescisória calcada no art. $485, \mathrm{~V}$, do $\mathrm{CPC}^{264}$.

Embora se possa discordar do entendimento do caráter público das horas extras, tal decisão deixa claro que, sendo questão de ordem pública, a matéria pode ser conhecida de ofício pelo Judiciário.

\footnotetext{
${ }^{262}$ Ver Anexo 2, Decisão 64 - PROC. No TST-E-RR-713.466/2000.0

${ }^{263}$ Ver Anexo 2, Decisão 130 - PROC. No TST-ROAR-1.925/2004-000-15-00.8

${ }^{264}$ Ver Anexo 2, Decisão 140 - PROC. No TST-ROAR-12814/2006-000-02-00.0
} 


\section{CONCLUSÃO}

Como visto brevemente na introdução histórica, a percepção da legislação trabalhista, por parte dos movimentos operários - não necessariamente por parte dos operários - é a de um instrumento de dominação, limitador do desenvolvimento da consciência de classe e impeditivo da consecução de um projeto revolucionário. Por outro lado, o desenvolvimento histórico dessa legislação - em oposição à ausência de uma mobilização social revolucionária vitoriosa - pode levar à crença que é possível considerar que esta regulamentação das relações de trabalho, com a manutenção do sistema capitalista, é, em grande parte, fruto da conformação dos trabalhadores que, em um exercício de sopesamento de prós e contras, optou pela via reformista.

Independentemente de como as normas laborais são vistas por seus sujeitos, o fato é que, mesmo tendo sido resultado de uma opção, a legislação trabalhista encontra-se, desde o fim do século XX, ameaçada de extinção, sem que surja, como contrapartida à sua abolição, um projeto de sociedade que vise a eliminação das desigualdades sociais. Pelo contrário, o neoliberalismo propõe apenas a revogação dos direitos trabalhistas, deixando que o conteúdo dos contratos individuais e coletivos de trabalho seja negociado entre sindicatos e empresas. Pois bem, como exposto, o enfraquecimento e a crise de representatividade dos sindicatos constituem o calcanhar de Aquiles da organização da classe trabalhadora. Tal enfraquecimento, se tem raízes na estrutura corporativista brasileira, também é resultado das novas formas de produção, em especial o toyotismo. Ademais, mesmo em países em que o sindicalismo tem uma atuação forte, sua capacidade de mobilização também está reduzida. Trata-se, portanto, de uma crise generalizada do movimento sindical, cujos motivos foram brevemente elencados no primeiro capítulo.

Assim, diante deste quadro de enfraquecimento da organização da classe trabalhadora, principal interessada na manutenção e na efetividade a legislação trabalhista, há que se recorrer ao Estado - fiador da efetividade - para que se garanta a ordem legal vigente. Tal socorro justifica-se, ainda, pelo fato de que o Estado Brasileiro reconhece como fundamentais os direitos dos trabalhadores e é baseado no valor social do trabalho. A atuação Estatal pode se dar por diversas frentes, sendo que interessou, para este trabalho, a via judicial, em especial o papel que o incremento dos poderes do juiz pode ter na resolução satisfatória dos conflitos sociais e na efetividade das normas de direito material. 
O princípio da congruência implica verdadeira restrição à atividade dos magistrados, sendo praticamente unânime a opinião de que é aplicável ao processo do trabalho, embora a sua terminologia e conceito não sejam bem definidos nem na doutrina nem na jurisprudência, tanto no campo do processo civil, quanto do processo laboral. Deste modo, buscou-se, em consonância com a teoria da instrumentalidade das formas processuais, definir o conceito de princípio da congruência de modo a aproximá-lo da necessidade de que a decisão judicial contemple toda a matéria trazida aos autos, garantindo a manifestação das partes sobre todas as questões relevantes, afastando-o do entendimento estrito de que a sentença deve ser um exercício de silogismo com o pedido expresso na petição.

A partir desde conceito, optou-se pela terminologia "congruência", mais afeita à semelhança do que à identidade. Não apenas é posição harmônica com os princípios do processo do trabalho, mormente a sua simplicidade e informalidade, mas também entendimento que vai ao encontro das mais recentes tendências do processo civil e a sua preocupação com o processo efetivo e econômico. Ou seja, não obstante as limitações impostas pelos artigos 128 e 460 do CPC, a flexibilização do conceito tradicional do princípio da congruência é perfeitamente compatível com nosso sistema processual. Em países de cultura jurídica similar à nossa, como o México e a Colômbia, a possibilidade de conhecimento de pedidos não expressamente formulados pelas partes está prevista na legislação processual laboral como regra!

A pesquisa doutrinária acerca das exceções ao princípio da congruência revelou, ainda, que embora pontuais, alguns dos casos em que é permitido ao juiz conhecer de pretensões não formuladas pelas partes guardam em comum o caráter público da norma material aplicável. Ademais, a mera leitura da lei indica que, em se tratando de norma de ordem pública, é permitido ao juiz conhecer de matéria não suscitada pela parte: tal é, $a$ contrario sensu, o que dispõe o artigo 128 do CPC. Por que, então, a resistência da doutrina em se afastar a aplicação rígida do princípio da congruência no processo do trabalho, considerando que, em regra, as normas materiais de direito do trabalho são indisponíveis? Para responder a esta pergunta, foi feita pesquisa no sítio eletrônico do TST, de modo a apreender como este tribunal lida com o princípio da congruência.

$\mathrm{O}$ resultado da pesquisa de campo foi surpreendente: em $72 \%$ dos casos, embora tenha havido reconhecimento da inexistência de pedido expresso em relação a determinada verba ou conseqüência jurídica, o TST manteve a decisão que a deferiu, utilizando-se dos mais diversos argumentos, entre eles a simplicidade do processo do trabalho e a 
indisponibilidade dos direitos trabalhistas. Nota-se, portanto, que os estudos teóricos de direito processual do trabalho estão muito distantes da realidade quando, sem pestanejar, pregam pela aplicação automática dos artigos 128 e 460 do CPC ao processo laboral. A jurisprudência, como fonte do direito, não pode ser menosprezada, em especial em casos em que a questão discutida - neste caso, um problema de linguagem entre o que é pedido e o que é concedido - não pode ser exaurida hipoteticamente, sendo imperativa a observância das dificuldades práticas que surgem quando da elaboração da petição inicial e da prolação da sentença.

Conclui-se, portanto, que o princípio da congruência deve ser entendido não como uma regra rígida de vinculação da sentença com os pedidos feitos pelas partes, mas sim como o respeito, pelo magistrado, ao princípio do contraditório, decidindo sempre com base nos elementos trazidos aos autos, não necessariamente no rol dos pedidos, e dando às partes a oportunidade de se manifestar. Trata-se de cuidado que se recomenda ter mesmo em situações relativas a normas de ordem pública, para consagrar-se a democracia no processo. Deste modo, há real aproximação entre o devido processo legal e o processo justo e efetivo.

Contudo, há que se reconhecer que a falta de regulamentação legal acerca da possibilidade de o juiz conhecer de ofício pedidos não formulados expressamente e a pouca atenção que este tema recebe da doutrina constituem uma dificuldade procedimental e geram insegurança jurídica. Assim, sugere-se a elaboração de lei para inserir na CLT, a exemplo do artigo 685 da lei trabalhista mexicana, permissão aos magistrados para que, ao perceberem que a demanda do trabalhador está incompleta, ou quando não compreenda todos os direitos que decorrem da relação empregatícia em juízo, possam advertir as partes, dando-lhes prazo para que se manifestem, e conhecer, de ofício, das questões que envolvam direitos indisponíveis. 


\section{REFERÊNCIAS BIBLIOGRÁFICAS}

ALMEIDA, Isis de. O 'Jus Postulandi' das Partes na Justiça do Trabalho e os Princípios Básicos do Direito do Trabalho. Revista da Academia Nacional de Direito do Trabalho, São Paulo, n. 03, p. 85-89, 1995.

ALMEIDA, José Carlos de Araújo. O pedido no sistema da common law e o princípio da adstrição. Revista de Processo, São Paulo, n. 118, ano 29, nov./dez. 2204, p. 89-109.

ALVES, Giovanni. O novo (e precário) mundo do trabalho: reestruturação produtiva e crise do sindicalismo. São Paulo: Boitempo, 2000.

Trabalho e sindicalismo no Brasil: um balanço crítico da "década neoliberal" (1990-2000). Revista de Sociologia e Política, Curitiba, n. 19, p. 71-94, nov. 2002.

ALVIM, Eduardo Arruda. Manual de direito processual civil. São Paulo: Revista dos Tribunais, 1998.

AMENDOEIRA JÚNIOR, Sidnei. Fungibilidade de Meios. São Paulo: Atlas, 2008.

ANTUNES, Ricardo. Construção e desconstrução da legislação social no Brasil. In: (Org.). Riqueza e miséria do trabalho no Brasil. São Paulo: Boitempo, 2006.

. Os sentidos do trabalho. São Paulo: Boitempo, 2000.

ARAÚJO CINTRA, Antônio Carlos. Comentários ao Código de Processo Civil. Rio de Janeiro, Forense, 2008.

ARRUDA ALVIM, José Manuel de. Dogmática jurídica e o novo código de processo civil. Revista de Processo, São Paulo, v. 1, n. 1, p. 85-133, jan./mar. 1976.

. Manual de direito processual civil. v. 2. São Paulo: Revista dos Tribunais, 2008.

AZEVEDO, Raquel de. A resistência anarquista: uma questão de identidade (1927-1937). São Paulo: Arquivo do Estado; Imprensa Oficial, 2002.

BARBOSA MOREIRA, José Carlos. Reformas processuais e poderes do juiz. In: (Org.). Temas de direito processual. Saraiva, São Paulo: 2004.

. Correlação entre pedido e sentença. Revista de Processo, São Paulo, v. 21, n. 83, p. 207-215, jul./set. 1996.

BARROSO, Luis Roberto. Interpretação e aplicação da Constituição. São Paulo: Saraiva, 2008. 
BEDAQUE, José Roberto dos Santos. Efetividade do Processo e Técnica Processual. São Paulo: Malheiros, 2007.

BEDAQUE, José Roberto dos Santos. Direito e Processo - influência do direito material sobre o processo. São Paulo: Malheiros, 2009.

. Poderes instrutórios do juiz. São Paulo: Revista dos Tribunais, 2009.

et al. Código de Processo Civil interpretado. São Paulo: Atlas, 2005.

BERNARDO, João. Transnacionalização do capital e fragmentação dos trabalhadores: ainda há lugar para os sindicatos? São Paulo: Boitempo, 2000.

BEZERRA LEITE, Carlos Henrique. Curso de direito processual do trabalho. São Paulo: LTr, 2007.

BOBBIO, Norberto. A era dos direitos. Rio de Janeiro: Elsevier, 2004.

BOTELHO DE MESQUITA, José Ignácio. A 'causa petendi' nas ações reivindicatórias. Revista de Direito Processual Civil, São Paulo, ano III, v. 6, p. 183-198, 1962.

BOUCINHAS FILHO, Jorge Cavalcanti. A inversão do ônus da prova no processo do trabalho. Disponível em: <http://jus2.uol.com.br/DOUTRINA/texto.asp?id=10176>. Acesso em: 17 dez. 2010.

BRASIL. Decreto $\mathrm{n}^{\circ} 21.396$ de 12 de maio de 1932. Institui comissões mistas de conciliação e dá outras providências. Coleção das Leis da República dos Estados Unidos do Brasil de 1932. Atos do Governo Provisório. Rio de Janeiro: Imprensa Nacional, 1943. p. 235 e ss. Disponível em: <http://www.camara.gov.br/internet/ InfDoc/novoconteudo/legislacao/republica/Leis1932vII624p/pdf29.pdf>. Acesso em: 17 dez. 2010.

. Lei $\mathrm{n}^{\circ} 108$ de 11 de outubro de 1837. Dando varias providencias sobre os Contractos de locação de serviços dos Colonos. Coleção das Leis do Império do Brasil. Atos do Poder Legislativo (CLIB-APL). Parte Segunda. Rio de Janeiro: Tipografia Nacional, 1861. p. 39 e 40. Disponível em: <http://www.camara.gov.br/ Internet/InfDoc/conteudo/colecoes/Legislacao/Legimp-23/Legimp-23._9.pdf >. Acesso em: 17 dez. 2010.

Lei $\mathrm{n}^{\circ} 11.637$ de 5 de novembro de 1907. Cria sindicatos profissionais $e$ cooperativas. Coleção das Leis de 1907. Atos do Poder Legislativo. Rio de Janeiro: Imprensa Nacional, 1941. p. 38 e 39. Disponível em: <http://www.camara.gov.br/ Internet/InfDoc/novoconteudo/Legislacao/Republica/leisocerizadas/Leis1907vIleg.pdf>. Acesso em: 17 dez. 2010.

CÂMARA DOS DEPUTADOS. Disponível em: <http://www2.camara.gov.br/>. Acesso em: 21 dez. 2010.

CARDOSO, Adalberto Moreira. Sindicatos, trabalhadores e a coqueluche neoliberal: a era Vargas Acabou? São Paulo: Fundação Getúlio Vargas, 1999. 
CARMONA, Carlos Alberto. Em torno da petição inicial. Revista de Processo, São Paulo, v. 30, n. 119, p. 11-34, jan. 2005.

CATHARINO, José Martins. Compêndio de Direito do Trabalho. v. 1. São Paulo: Saraiva, 1981.

CESARINO JUNIOR, Antônio Ferreira. Direito Social. São Paulo: LTr , 1980.

COLÔMBIA. Código Procesal del Trabajo y de la Seguridad Social. Decreto-Ley 2158/1948. Disponível em: <http://www.secretariasenado.gov.co/senado/basedoc/ codigo/codigo_procedimental_laboral.html>. Acesso em: 17 dez. 2010.

COMISSÃO INTERAMERICANA DE DIREITOS HUMANOS. Disponível em: $<$ http://www.cidh.org > Acesso em: 21 dez. 2010.

Relatório Anual 200. Relatório no 54/01, Caso 12.051, Maria da Penha Maia Fernandes. Disponível em: <http://www.cidh.org/annualrep/2000port/12051.htm>. Acesso em: 17 dez. 2010.

COMPARATO, Fábio Konder. Afirmação histórica dos direitos humanos. São Paulo: Saraiva, 2003.

CONSELHO NACIONAL DE JUSTIÇA. Disponível em: <http://www.cnj.jus.br/>. Acesso em: 21 dez. 2010.

COUTURE, Eduardo. Algunas nociones fundamentales del derecho procesal del trabajo. Santa Fé: Instituto de Derecho del Trabajo; Facultad de Ciencia Juridicas y Sociales, 1941.

CRETELLA JUNIOR, José. Curso de Direito Romano. Rio de Janeiro: Forense, 1999.

CRETELLA NETO, José. Fundamentos principiológicos do processo civil. Rio de Janeiro: Forense, 2002.

CRUZ E TUCCI, José Rogério. A 'causa petendi' no processo civil. São Paulo: Revista dos Tribunais, 2001.

CUEVA, Mario de la. El nuevo derecho mexicano del trabalho. México: Porruá, 1977.

D'ARAÚJO, Maria Celina. Estado, classe trabalhadora e políticas sociais. In: FERREIRA, Jorge; DELGADO, Lucilia de Almeida Neves (Org.). O tempo do nacional-estatismo: do início da década de 1930 ao apogeu do Estado Novo. Rio de Janeiro: Civilização Brasileira, 2003.

D’AURIA, Aníbal et al. El anarquismo frente ao derecho. Buenos Aires: Utopia Libertaria, 2007.

DAREHNDORF, Ralf. Las clases sociales e su conflicto em la sociedad industrial. Madrid: Rialp, 1962. 
DECCA, Edgar de. 1930, o silêncio dos vencidos: memória, história e revolução. São Paulo: Brasiliense, 1992.

DECLARAÇÃO UNIVERSAL DOS DIREITOS HUMANOS DA ORGANIZAÇÃO DAS NAÇÕES UNIDAS. Preâmbulo. Versão em português disponível em: $<$ http://www.ohchr.org/EN/UDHR/ Pages/Language.aspx?LangID=por>. Acesso em: 17 dez. 2010.

DELGADO, Maurício Godinho. Capitalismo, trabalho e emprego. São Paulo: LTr, 2008.

DIDIER JUNIOR, Fredie. Curso de direito processual civil. Salvador: JusPodivm, 2008.

DINAMARCO, Cândido Rangel. Instituições de Direito Processual Civil. v. 2. São Paulo: Malheiros, 2001.

. Instituições de Direito Processual Civil. v. 3. São Paulo: Malheiros, 2002.

.; CINTRA, Antônio Carlos de Araújo; GRINOVER, Ada Pelegrini. Teoria Geral do Processo. São Paulo: Malheiros, 2003.

ELEY, Geof. Forjando a democracia: a história da esquerda na Europa, 1850-2000. São Paulo: Fundação Perseu Abramo, 2005.

ELIAS, Carlos Eduardo Stefen. As reformas processuais e o princípio da congruência entre sentença e o pedido. Revista de Processo, São Paulo, v. 33, n. 58, p. 38-64, abr. 2008.

FARIA, Ernesto. Dicionário Escolar Latino-Português. Rio de Janeiro: Campanha Nacional de Material de Ensino, 1956.

FARIA, José Eduardo. Justiça e conflito - os juízes em face dos novos movimentos sociais. São Paulo: Revista dos Tribunais, 1991.

FAUSTO, Boris. Trabalho urbano e conflito social (1890-1920). São Paulo: DIFEL, 1986. História do Brasil. São Paulo: Edusp, 1997.

FERRÃO, Brisa Lopes de Mello; RIBEIRO, Ivan Cesar. Os Juízes Brasileiros Favorecem a Parte Mais Fraca? Revista de Direito Administrativo, Rio de Janeiro, v. 244, p. 5382, 2007. Disponível em: < http://escholarship.org/uc/item/0715991z\#page-7 >. Acesso em: 17 dez. 2010.

FERRAZ JUNIOR, Tercio Sampaio. Introdução ao estudo do direito - técnica, decisão dominação. São Paulo: Atlas, 2001.

FERREIRA, Jorge. O imaginário trabalhista: getulismo, PTB e cultura política popular, 1945-1964. Rio de Janeiro: Civilização Brasileira, 2005.

FRENCH, John D. Afogados em leis: a CLT e a cultura política dos trabalhadores brasileiros. São Paulo: Fundação Perseu Abramo, 2001. 
GIGLIO, Wagner D. (Coord.). Processo do Trabalho na América Latina. São Paulo: LTr , 1992.

.; CORRÊA, Cláudia Giglio Veltri. Direito Processual do Trabalho. São Paulo: Saraiva, 2005.

GODEGHESI, Luis Henrique Simão. A ampliação da competência da justiça do trabalho e seus impactos no 'ius postulandi'. São Paulo, 2009. 112 f. Dissertação (Mestrado em Direito do Trabalho) - Faculdade de Direito da Universidade de São Paulo. Orientação do Professor Ari Possidonio Beltran.

GOMES, Orlando. Curso elementar de Direito do trabalho. São Paulo: Forense, 1963.

GRECO FILHO, Vicente. Direito Processual Brasileiro. v. 2. São Paulo: Saraiva, 2000.

GRINOVER, Ada Pelegrini. O Processo Constitucional em marcha. São Paulo: Max Limonad, 1985.

HARDMAN, Francisco Foot; LEONARDI, Victor. História da indústria e do trabalho no Brasil: das origens aos anos vinte. São Paulo: Global, 1982.

HIRANO, Ana Farias. Acordos Homologados pela Justiça do Trabalho: Transação de Direitos Controvertidos ou Renúncia a Direitos Indisponíveis? São Paulo, 2009. $280 \mathrm{f}$. Dissertação (Mestrado) - Faculdade de Direito da Universidade de São Paulo. Orientação do Professor Jorge Luiz Souto Maior. Disponível em: <http://www.teses.usp.br/teses/disponiveis/2/2138/tde-13082009-092724/>. Acesso em: 21 dez. 2010.

HOUAISS, Antônio; VILLAR, Mauro de Salles. Dicionário Houaiss da Língua Portuguesa. Elaborado pelo Instituto Antônio Houaiss de Lexicografia e Banco de Dados da Língua Portuguesa. Rio de Janeiro: Objetiva, 2009. CD-ROM.

HUBERMAN, Leo. História da riqueza do homem. Rio de Janeiro: Zahar, 1977.

JAUERNIG, Othmar. Direito processual civil. Coimbra: Almedina, 2002.

JORGE, Mario Helton. A garantia de imparcialidade do órgão jurisdicional e as hipóteses de aparente parcialidade. Revista dos Tribunais, São Paulo, v. 95, n. 844, p. 56-68, jan. 2008.

O regime jurídico da fungibilidade das demandas e dos provimentos no CPC. Revista de Processo, São Paulo, v. 30, n. 122, p. 41-62, abr. 2005.

KELSEN, Hans. Teoria pura do Direito. Coimbra: Armênio Amado, 1974.

KHAYAT, Mariane. O julgador diante da inércia do demandante em relação ao pedido. $L T r$ - Suplemento Trabalhista, São Paulo, v. 26, n. 52, p. 273-274, 1990.

LASSALE, Ferdinand. Qué es la Constituición? Santa Fe de Bogotá: Temis, 1997. 
LIEBMAN, Enrico Tulio. O despacho saneador e o julgamento do mérito. Revista dos Tribunais, São Paulo, v. 88, n. 767, p. 737-753, set. 1999.

LINDGREN ALVES, José Augusto. Os Direitos Humanos como Tema Global. São Paulo; Brasília: Perspectiva; Fundação Alexandre Gusmão, 1994.

LOPREATO, Christina Roquette. O espírito da revolta: a greve geral anarquista de 1917. São Paulo: Annablume, 2000.

MACHADO, Antônio Cláudio da Costa. Código de processo civil interpretado e anotado. São Paulo: Manole, 2008.

MARCATO, Antonio Carlos. Procedimentos especiais. São Paulo: Atlas, 2006.

MARTINELLI, Mario Eduardo. A deterioração dos direitos de igualdade material no neoliberalismo. Campinas: Milennium, 2000.

MÉXICO. Ley Federal Del Trabajo. Disponível em: <http://www.cddhcu.gob.mx/ LeyesBiblio/pdf/125.pdf>. Acesso em: 20 jun. 2010.

NASCIMENTO, Amauri Mascaro. Curso de Direito processual do trabalho. São Paulo: Saraiva 1997.

. Direito Sindical. São Paulo: Saraiva, 1991.

NETTO, José Nascimento Araujo. Liberalismo e Justiça do Trabalho: seis décadas de confronto. Rio de Janeiro: Forense, 2006.

NICARAGUA. Código del Trabajo. Ley 185/1996. Disponível em: $<$ http://www.ilo.org/dyn/natlex/docs/WEBTEXT/45784/65050/S96NIC01.htm\#12t1c>. Acesso em: 17 dez. 2010.

OLIVEIRA, Vallisney de Souza. Nulidade da sentença e o princípio da congruência. São Paulo: Saraiva, 2004.

PAUlA, Alexandre de. Código de Processo Civil Anotado. v. 2. São Paulo: Revista dos Tribunais, 1986.

PARAGUAI. Código Procesal del Trabajo. Ley 742/1961. Disponível em: $<$ http://www.senado.gov.py/leyes/?pagina=ley_resultado\&id=3919]>. Acesso em: 17 dez. 2010.

PARSONS, Talcott. Sociedades: perspectivas evolutivas e comparativas. São Paulo: Pioneira, 1969.

PIMENTA BUENO, José Antônio. Apontamentos sobre as formalidades no Processo Civil. Rio de Janeiro: Typographia Nacional, 1858. 
PIMENTA, José Roberto Freire. A conciliação judicial na justiça do trabalho após a emenda constitucional n. 24/99: aspectos de Direito comparado e o novo papel do juiz do trabalho. LTr : legislação do trabalho, São Paulo, v. 65, n. 2, p. 151-162, fev. 2001.

PLÁ RODRIGUES, Américo. Princípios de Direito do Trabalho. São Paulo: LTr , 1978.

. Visión crítica del derecho del trabajo. In: GIGLIO, Wagner D. (Coord.). Processo do Trabalho na América Latina. São Paulo: LTr , 1992.

PONTES DE MIRANDA, Francisco Cavalcanti. Comentários ao Código de Processo Civil. São Paulo: Forense, 1974.

PORTANOVA, Rui. Motivações ideológicas da sentença. Porto Alegre: Livraria do Advogado, 1994.

POPINIGIS, Fabiane. Proletários de casaca: trabalhadores do comércio carioca (18501911). Campinas: Unicamp, 2007.

RIBEIRO, Paulo de Tarso Ramos. Processo e Conflito: a crise de legitimação das decisões judiciais. Revista de Direito Alternativo, São Paulo, n. 1, p. 77-94, 1992.

RIFKIN, Jeremy. The end of work: the decline of the global labor force and the dawn of the post-market era. New York: Jeremy P. Tarcher; Penguin, 2004.

ROLLEMBERG, Denise. Esquerdas revolucionárias e luta armada. In: FERREIRA, Jorge; DELGADO, Lucilia de Almeida Neves (Org.). Brasil Republicano. Rio de Janeiro: Civilização Brasileira, 2003.

SALGADO, Edmar Souza. O princípio da efetividade no processo do trabalho. São Paulo, 2008. 264 f. Dissertação (Mestrado) - Faculdade de Direito da Universidade de São Paulo. Orientação do Professor Jorge Luiz Souto Maior.

SANTOS, Boaventura de Souza. Introdução à sociologia da administração da justiça. In: FARIA, José Eduardo (Org.). Direito e Justiça. São Paulo: Ática, 1989.

SANTOS, Enoque Ribeiro dos. O Direito coletivo do trabalho sob a perspectiva histórica. In: SOUTO MAIOR, Jorge Luiz (Org.). Curso de Direito do trabalho. São Paulo: LTr , 2007.

SARTHOU, Helious. Proposiciones sobre un derecho procesal laboral autônomo. Revista Derecho Laboral, Montevideo, t. XIX, n. 101-104, 1976.

SAVIGNY, Friedrich Carl von. Sistema del diritto romano attuale. Turim: Unione, 1886.

SILVA, Homero Batista Mateus da. Curso de Direito do Trabalho Aplicado: Processo do Trabalho. São Paulo: Elsevier, 2010.

SILVA, Octacílio Paula. Evolução histórica do Direito processual do trabalho. In: BARROS, Alice Monteiro (Coord.). Compêndio de Direito Processual do Trabalho. São Paulo: LTr , 1998. 
SILVA, Walküre Lopes Ribeiro da. Direito do Trabalho Brasileiro: principais aspectos de sua evolução histórica e as propostas de modernização. Revista do Tribunal Superior do Trabalho, Brasília, v. 69, n. 2, p. 120-138, jul./dez. 2006.

SIMÃO, José Fernando. O Acessório Segue a Sorte do Principal no Sistema do Novo Código Civil? Disponível em: <http://www.professorsimao.com.br/artigos_simao_ o_acessorio.htm>. Acesso em: 17 dez. 2010.

SOUSA, Francisco Antônio. Novo dicionário Latino-Português. Porto: Lello \& Irmão, 1984.

SOUTO MAIOR, Jorge Luiz. O Direito do trabalho como instrumento de justiça social. São Paulo: LTr , 2000.

(Org.). Temas de processo do trabalho. LTR: São Paulo, 2000.

. Petição Inicial. São Paulo: LTr, 1996.

.; CORREIA, Marcus Orione Gonçalves. Curso de Direito Trabalho - Direito Coletivo do Trabalho. São Paulo: LTr, 2008.

STAFFORINI, Eduardo. Derecho procesal social. Buenos Aires: TEA, 1955.

SUSSEKIND, Arnaldo. Direito Internacional do Trabalho. São Paulo: LTr , 2000. . et al. Instituições de direito do trabalho. São Paulo: LTr, 2000.

TALAMINI, Eduardo. Tutela relativa aos deveres de fazer e não fazer. São Paulo: Revista dos Tribunais, 2001.

TEIXEIRA, Guilherme Freire de Barros. Teoria do Princípio da Fungibilidade. São Paulo: Revista dos Tribunais, 2008.

TEIXEIRA FILHO, Manoel Antonio. A prova no processo do trabalho. São Paulo: LTr, 1986.

TEIXEIRA FILHO, Manoel Antonio. A sentença no processo do trabalho. São Paulo: LTr, 2004.

THEODORO JUNIOR, Humberto. Curso de direito processual civil. v. I. Rio de Janeiro: Forense, 2002.

TOLEDO FILHO, Manoel Carlos. Fundamentos e perspectivas do processo trabalhista brasileiro. São Paulo, 2005. 307 f. Tese (Doutorado) - Faculdade de Direito da Universidade de São Paulo. Orientação do Professor Marcus Orione Gonçalves Correia.

TRIBUNAL REGIONAL DO TRABALHO DA 2a REGIÃO, disponível em: <http://www.trtsp.jus.br/>. Acesso em: 21 dez. 2010. 
TRIBUNAL SUPERIOR DO TRABALHO. Disponível em: <http://www.tst.jus.br>. Acesso em: 21 dez. 2010.

TRUEBA URBINA, Alberto. Nuevo derecho procesal del trabajo. México: Porruá, 1973.

URUGUAI. Código General del Proceso. Ley 15.982/1988. Disponível em: $<$ http://www.parlamento.gub.uy/leyes/AccesoTextoLey.asp?Ley=15982\&Anchor=>. Acesso em: 17 dez. 2010.

VELHO, Christiane Moura. Da sentença 'extra' e 'ultra petita' e a Justiça do Trabalho. Campinas: 2004. 41 f. Monografia (Curso de Especialização em Direito e Processo do Trabalho) - Pontifícia Universidade Católica de Campinas. Orientação do Professor Manoel Carlos Toledo Filho.

WAMBIER, Teresa Arruda Alvim. O princípio da fungibilidade sob a ótica da função instrumental do processo. In: .; NERY JUNIOR, Nelson (Org.). Aspectos Polêmicos e Atuais dos Recursos Cíveis. v. 8. São Paulo: Revista dos Tribunais, 2005.

WATANABE, Kazuo. Da Cognição no Processo Civil. São Paulo: Revista dos Tribunais, 1987. 
ANEXO 1

MODELO DE FICHAMENTO 
SDI-2 - ULTRA PETITA - 2006

A- ASSUNTO

B- NÃO HÁ PEDIDO EXPRESSO/ PEDIDO IRRELEVANTE

SE B

B1 - DECRETA NULIDADE/ALTERA DECISÃO POR ULTRA PETIÇÃO OU MANTÉM DECISÃO NESSE SENTIDO

B2 - RECONHECE ULTRA PETIÇÃO, MAS NÃO ANULA/MODIFICA OU MANTÉM DECISÃO NESSE SENTIDO

B3 - NÃO RECONHECE ULTRA PETIÇÃO E NÃO ANULA/MODIFICA OU MANTÉM DECISÃO NESSE SENTIDO

SE B1, B2 OU B3 - JUSTIFICATIVA

C - HÁ PEDIDO, MAS NÃO HÁ, SUPOSTAMENTE, o FUNDAMENTO ADOTADO

SE C

C1 - DECRETA NULIDADE/ALTERA DECISÃO POR ULTRA PETIÇÃO OU MANTÉM DECISÃO NESSE SENTIDO

C2 - RECONHECE ULTRA PETIÇÃO, MAS NÃO ANULA/MODIFICA OU MANTÉM DECISÃO NESSE SENTIDO

C3 - NÃO RECONHECE ULTRA PETIÇÃO E NÃO ANULA/MODIFICA OU MANTÉM DECISÃO NESSE SENTIDO

SE C1, C2 OU C3 - JUSTIFICATIVA 
ANEXO 2

LISTA DE PROCESSOS 


\section{Decisões Ultra Petita}

\section{Seção de Dissídios Individuais I do Tribunal Superior do Trabalho}

\section{5}

1. TST-E-RR-469.561/98.3, Banco Bamerindus do Brasil S.A. x Hamilton Mário de Oliveira, Ministro Relator João Oreste Dalazen, 16.05.2005.

2. TST-E-RR-549.127/1999.6, BRB - Banco de Brasília S.A. x Marco Aurélio Motta Ferreira, Ministro Relator Aloysio Corrêa da Veiga, 14.11.2005.

3. TST-E-RR-485.597/98.8, Júlio César Patrício x Administração dos Portos de Paranaguá e Antonina - APPA, Juiz Convocado Relator José Antonio Pancotti, 12.09.2005.

4. TST-E-RR-644.881/2000.3, Caixa Econômica Federal x Elizete dos Santos Dorow, Ministro Relator Lelio Bentes Corrêa, 18.04.2005.

5. TST-E-RR-597.175/1999.5, Hercules Corretora de Seguros LTDA x Elaine Andrade de Oliveira, Ministra Relatora Maria Cristina Irigoyen Peduzzi, 26.09.2005.

6. TST-E-RR-427.233/1998.9, Empresa Ferreira de Prestação de Serviços LTDA x Rodrigo Serpa Inácio, Ministro Relator Aloysio Corrêa da Veiga, 27.06.2005.

7. TST-E-RR-553.807/99.4, Companhia Riograndense de Saneamento CORSAN x Odílio Alves de Almeida, Ministro Relator João Oreste Dalazen, 28.03.2005.

8. TST-E-RR-414.126/1998.3, Petróleo Brasileiro S.A. - Petrobrás x Manoel Do Socorro Da Conceição, Ministro Relator Carlos Alberto Reis de Paula, 21.03.2005.

\section{6}

9. TST-E-AG e ED-RR-1168/2000-002-17-00.0, Marcos David Mariano Simões x Companhia Siderúrgica De Tubarão - CST, Ministro Relator José Luciano de Castilho Pereira, 19.06.2006.

10. TST-E-RR-804.316/2001.7, Brasil Telecom S.A. - TELESC x Vitor Luiz Ramos Batista, Ministro Relator Aloysio Corrêa da Veiga, 28.08.2006.

11. TST-E-RR-519.236/98.3, Viação Aérea Rio Grandense S.A. - VARIG x Luiz Henrique Caldonazi Pereira, Ministro Relator Milton de Moura França, 19.09.2006.

12. TST-E-RR-563.270/1999.5, Unibanco - União De Bancos Brasileiros S.A. $\mathrm{x}$ Everton Evelyn De Araújo Goes, Ministro Relator Lelio Bentes Corrêa, 28.08.2006.

13. TST-E-RR-691.304/2000.8, Credial Empreendimentos e Serviços LTDA x José Aparecido Virgínio Da Silva, Ministra Relatora Maria Cristina Irigoyen Peduzzi, 28.11.2006.

14. TST-E-RR-670.589/2000.2, Banco Martinelli S.A. x Luis Da Conceição Fernandes, Ministra Relatora Maria Cristina Irigoyen Peduzzi, 28.11.2006.

15. TST-E-RR-660.654/2000.9, Banco do Estado do Rio de Janeiro S.A. (Em Liquidação Extrajudicial) x Raimundo Lindolfo Guimarães Oliveira e Banco Itaú S/A, Ministro Relator Lelio Bentes Corrêa, 10.04.2006.

16. TST-E-RR-648103/2000.1, Oxfort Construções S.A. x Letícia Lumi Kayano, Ministro Relator Carlos Alberto Reis de Paula, 25.09.2006.

17. TST-E-RR-531160/1999.0, Klabin Fabricadora de Papel e Celulose S.A. x Carlos Alberto Simões de Mattos, Ministro Relator Carlos Alberto Reis de Paula, 31.10.2006. 
18. TST-E-RR-794.166/2001.6, Brasil Telecom S.A. - TELESC x Lunalva Pereira, Ministro Relator Aloysio Corrêa da Veiga, 21.08.2006.

\section{7}

19. TST-E-ED-RR-2.373/1999-014-15-00.0, Indsteel S.A. Indústria e Comércio $x$ Antônio Pires de Andrade, Ministra Relatora Maria Cristina Irigoyen Peduzzi, 03.12.2007.

20. TST-E-RR-554.037/1999.0, Vale do Rio Doce Navegação S.A. - DOCENAVE x Antônio Oliveira Dias, Ministro Relator João Batista Brito Pereira, 08.10.2007.

21. TST-E-RR-416.267/1998.3, Banco Multiplic S.A. x Jorge Antônio Abreu, Ministro Relator Vantuil Abdala, 27.02.2007.

\section{8}

22. TST-E-RR-753.600/2001.9, S.A. O Estado De São Paulo x Alberto Pereira da Silva, Ministro Relator João Batista Brito Pereira, 18.12.2008.

23. TST-E-RR-759.930/2001.7, Companhia Riograndense de Saneamento CORSAN x STE - Serviços Técnicos de Engenharia S.A. e Ademar Zilio, Ministro Relator Aloysio Corrêa da Veiga, 30.06.2008.

24. TST-E-RR-658609/2000.8, Flávio de Jesus Pires x Companhia Paulista de Trens Metropolitanos - CPTM, Ministra Relatora Maria de Assis Calsing, 20.11.2008.

25. TST-E-ED-RR-708.307/2000.6, Onalvo Ferreira dos Santos x Segurança Tratex S.A., Ministro Relator Horácio Senna Pires, 08.09.2008.

26. TST-E-ED-RR-794886/2001.3, Aço Minas Gerais S.A. - AÇOMINAS x Jurandir Ferreira Pinto, Ministro Relator João Batista Brito Pereira, 07.04.2008.

27. TST-E-RR-638.486/2000.8, Nossa Caixa - Nosso Banco S.A. x Helena Aparecida Bardelotti Maruyama, Ministro Relator João Batista Brito Pereira, 06.10.2008.

28. TST-E-RR-649.965/2000.6, Banco do Estado do Paraná S.A. x Maria de Lourdes Silva, Redator Designado Vantuil Abdala, 27.11.2008.

29. TST-E-ED-RR-2.333/2005-018-09-00.5, Estado do Paraná x Maria Almizi Rodrigues Santos, Ministro Relator Vantuil Abdal, 05.05.2008.

\section{9}

30. TST-E-RR-626991/2000.1, Banco do Brasil S.A. x Paulo Edson de Oliveira, Ministro Relator Lelio Bentes Corrêa, 15.10.2009.

31. TST-E-RR-441162/1998.0, Banco do Brasil S.A. x Anísio Martins, Ministro Relator João Batista Brito Pereira, 24.09.2009.

32. TST-E-ED-RR-2576/2002-431-02-00.1, Confecções Diguinho Ltda. x Alaíde Fernandes Sampaio, Ministro Relator João Batista Brito Pereira, 10.12.2009.

33. TST-E-RR-700079/2000.8, Ailton Geraldo Teixeira e outros x Companhia Siderúrgica Belgo-Mineira, Ministro Relator João Batista Brito Pereira, 24.09.2009.

34. TST-E-RR-568.232/1999.6, Banco do Brasil S.A. x Carlos Magno Agostinho, Ministro Relator João Batista Brito Pereira, 10.09.2009.

\section{0}

35. TST-E-RR-E-RR-565264-27.1999.5.04.5555, Vera Candido Camacho x Caixa Econômica do Estado do Rio Grande do Sul, Ministro Relator João Batista Brito Pereira, 04.02.2010.

36. TST-E-RR-82400-13.2001.5.12.0023, Sonae Distribuição Brasil S.A. x Elemar Cardoso Trajano, Ministro Relator João Batista Brito Pereira,25.02.2010. 


\section{Seção de Dissídios Individuais II do Tribunal Superior do Trabalho}

\section{5}

37. TST-ROAR-41.116/2000-000-05-00.0, Banco do Brasil S.A. x Antônio Marcos Souza Santos, Ministro Relator Emmanoel Pereira, 22.02.2005.

38. TST-ROAR-1.194/2002-000-05-00.3, Banco do Brasil S.A. x Paulo de Tarso Machado de Carvalho, Ministro Relator Emmanoel Pereira, 25.10.2005.

39. TST-ROAR-1260/2003-000-04-00.1, Jorge Luiz Eloy Pereira X Arideu dos Santos Pereira, Ministro Relator José Simpliciano Fontes de F. Fernandes, 25.10.2005.

40. TST-RXOFROAR-801086/2001.3, Centro Federal de Educação Tecnológica do Paraná - Cefet e outra x Henrique da Silva Cardoso, Ministro Relator José Simpliciano Fontes de F. Fernandes, 13.12.2005.

41. TST-ED-ROAR-114.977/2003-900-02-00.5, Eduardo Flosi x Universidade de São Paulo - USP, Ministro Relator Gelson de Azevedo.

\section{6}

42. TST-ROAR-96895/2003-900-04-00.2, Banco Santander Meridional S/A x Paula Daniela Tanure, Ministro Relator José Simpliciano Fontes de F. Fernandes, 14.03.2006.

43. TST-ROAR-1.323/2002-000-05-00.3, Gerdau S.A. - Gerdau Usiba x Joselito dos Santos Barbosa, Ministro Relator Emmanoel Pereira, 07.02.2006.

44. TST-ROAR-1.852/2003-000-03-00.9, Banco do Brasil S.A. x Márcio Roberto Vieira, Ministro Relator Emmanoel Pereira, 16.05.2006.

45. TST-ROAR-1.388/2003-000-04-00.5, Campina Revenda de Óleos Ltda. $\mathrm{x}$ Oscar Julieto Rather, Ministro Relator Emmanoel Pereira, 07.11.2006.

46. TST-RXOF e ROAR-540/2002-000-15-00.1, Hospital das Clínicas da Faculdade de Medicina de Ribeirão Preto da Universidade de São Paulo x Rebeca Del Mônaco Drummond Ferreira, Ministro Relator Ives Gandra Martins Filho, 07.02.2006.

\section{7}

47. TST-ED-ROAR-310/2006-000-12-00.2, Fundação Universitária do Desenvolvimento do Oeste - Fundeste x Lúcia Morosini Frazzon, Ministro Relator José Simpliciano Fontes de F. Fernandes, 04.12.2007.

48. TST-ROAR-6247/2003-909-09-00.2, José Adair Fontoura Oliveira x Yoshiyuki Ban, Ministro Relator José Simpliciano Fontes de F. Fernandes, 08.05.2007.

49. TST-ROAC-414/2005-000-15-00.0, Unidade Radiológica S/C Ltda. e Ronaldo Abdala x Danny Santucci Antunes, Juíza Convocada Relatora Kátia Magalhães Arruda, 23.10.2007.

\section{8}

50. TST-ROAR-327/2007-000-04-00.4, Caixa Econômica Federal - CEF x Maria Aparecida da Silva Vanzetto, Relator Ministro Pedro Paulo Manus, 13.05.2008.

51. TST-ROAR-399/2004-000-12-00.5, A Notícia S.A. - Empresa Jornalística x Gilberto Viegas, Ministro Relator Ives Gandra Martins Filho, 09.09.2008.

52. TST-ROAR-41.008/2001-000-05-00.8, Bompreço Bahia S.A. x Elza Silva Santana, Ministro Relator Renato de Lacerda Paiva, 10.06.2008.

53. TST-ROAR-953/2002-000-03-00.1, Ford Comércio e Serviços Ltda. x Marlúcia Carla Alves Gualberto, Ministro Relator Renato de Lacerda Paiva, 04.11.2008.

54. TST-ROAR-399/2004-000-12-00.5, A Notícia S.A. - Empresa Jornalística x 


\begin{tabular}{|c|}
\hline Gilberto Viegas, Ministro Relator Ives Gandra Martins Filho, 09.09.2008. \\
\hline 2009 \\
\hline $\begin{array}{l}\text { 55. TST-ROAR-635/2008-909-09-00.4, Caixa Econômica Federal - CEF x Zuleika } \\
\text { Marques Doroso, Ministro Relator José Simpliciano Fontes de F. Fernandes, } \\
\text { 18.08.2009. }\end{array}$ \\
\hline $\begin{array}{l}\text { 56. TST-ROAR-317/2004-000-20-00.9, Unilever Bestfoods Brasil Ltda.x Carlos } \\
\text { Ivanir Fróes Serôa de Oliveira, Ministro Relator Renato de Lacerda Paiva, } \\
\text { 06.10.2009. }\end{array}$ \\
\hline $\begin{array}{l}\text { 57. TST-ROAR-627/2001-000-17-00.7, Hospital Metropolitano Ltda. e Fernando } \\
\text { Alberto Cunha Trigo x F. C. Técnicos de Radiologia Ltda., Ministro Relator } \\
\text { José Simpliciano Fontes de F. Fernandes, 05.05.2009. }\end{array}$ \\
\hline $\begin{array}{l}\text { 58. TST-ROAR-400/2003-000-04-00.4, IBS - Indústria de Balanças e Serviços } \\
\text { Ltda e outra x Fábio Henrique da Silva Marçal, Ministro Relator Renato de } \\
\text { Lacerda Paiva, 23.06.2009. }\end{array}$ \\
\hline $\begin{array}{l}\text { 59. TST-ROAR-359/2007-000-18-00.3, Hailton Ribeiro dos Santos x Luiz } \\
\text { Henrique Meireles Vasconcelos e Alles Industrial, Ministro Relator Ives } \\
\text { Gandra Martins Filho, 24.03.2009. }\end{array}$ \\
\hline 2010 \\
\hline $\begin{array}{l}\text { 60. TST-Ag-ROMS-41600-47.2009.5.15.0000, João Batista de Melo e outra x } \\
\text { Waldimir Ferreira Machado e Entreposto Goiano Ltda. e outros, Ministro } \\
\text { Relator Renato de Lacerda Paiva, 23.03.2010. }\end{array}$ \\
\hline $\begin{array}{l}\text { 61. TST-16800-93.2007.5.16.0000, Luciléa Mamede Santos x Unihosp Serviços de } \\
\text { Saúde Ltda. e Long Life - Sistema Internacional De Saúde Ltda., Ministro } \\
\text { Relator Emmanoel Pereira, 02.02.2010. }\end{array}$ \\
\hline $\begin{array}{l}\text { 62. TST-ROAR-167000-42.2007.5.15.0000, Antônio Pompílio da Silva x Zf do } \\
\text { Brasil Ltda., Relator Ministro Barros Levenhagen, 13.04.2010. }\end{array}$ \\
\hline
\end{tabular}

\section{Decisões Extra Petita}

\section{Seção de Dissídios Individuais I do Tribunal Superior do Trabalho} 2005

63. TST-ED-E-RR-98321/2003-900-02-00.0, Geraldo Taumaturgo Dias x Banco do Estado de São Paulo S.A. - Banespa, Ministro Relator Aloysio Corrêa da Veiga, 16.05.2005.

64. TST-E-RR-713.466/2000.0, Companhia de Saneamento Básico do Estado de São Paulo - Sabesp x Ministério Público do Trabalho da $2^{\mathrm{a}}$ Região e Carlos Antônio Fernandes, Relator Carlos Alberto Reis de Paula, 03.10.2005.

65. TST-E-RR-563.143/99.7, Companhia Riograndense De Saneamento - Corsan x Ana Lúcia Scherer e Magna Engenharia Ltda., Ministro Relator João Oreste Dalazen, 23.05.2005.

66. TST-E-RR-291.835/96.8, Pedro de Oliveira Freitas e outros x Companhia Estadual de Energia Elétrica - CEEE, Relator Juiz Convocado José Antonio Pancotti, 26.09.2005.

67. TST-E-RR-539.310/1999.0, Lisiane Gonçalves da Rocha x Banco do Brasil S.A., Ministra Relatora Maria Cristina Irigoyen Peduzzi, 12.09.2005.

68. TST-A-E-RR-384.859/1997.1, Banco do Estado do Paraná S.A. x Luiz Alberto Bonvin, Ministro Relator João Batista Brito Pereira, 05.12.2005.

69. TST-E-RR-664.409/2000.9, Goodyear do Brasil Produtos de Borracha Ltda. x Gilmar Liesel, Ministro Relator Aloysio Corrêa da Veiga, 16.05.2005. 
70. TST-E-RR-478.483/98.5, Companhia Vale do Rio Doce - CVRD x Maria Alice de Jesus Sá Peixoto, Relator Juiz Convocado José Antonio Pancotti, 28.11.2005.

71. TST-E-RR-640.811/00.6, Companhia Siderúrgica de Tubarão - CST x Rui Barbosa Xavier, Ministro Relator João Oreste Dalazen, 20.06.2005.

72. TST-E-ED-RR-747.726/2001.3, Companhia Riograndense de Saneamento Corsan x Iraci Maria Guglielmin Troian, Ministra Relatora Maria Cristina Irigoyen Peduzzi, 22.08.2005.

\section{6}

73. TST-A-E-RR-372.864/1997.8, Maximiliano Gaidzinski S.A. - Indústria de Azulejos Eliane x Valmor Garcia da Silva, Ministro Relator João Batista Brito Pereira, 13.02.2006.

74. TST-E-RR-669.489/00.7, Banco Itaú S/A x Paulo Roberto Antonietto, Ministro Redator Designado João Oreste Dalazen, 19.06.2006.

75. TST-E-RR-728770/2001.6, Aparecida Donizete Tavares $x$ Van Leer Embalagens Industriais do Brasil Ltda., Ministro Relator Carlos Alberto Reis de Paula, 21.08.2006.

76. TST-E-RR-459.147/1998.7, Banco do Estado do Rio Grande do Sul S.A. Banrisul x Aníbal Wunsch, Ministra Relatora Maria Cristina Irigoyen Peduzzi, 13.02.2006.

77. TST-E-RR-172/2000-020-15-00.4, Bandeirante Energia S.A. x Carlos Eduardo Broccanelli Carneiro, Relator Carlos Alberto Reis de Paula, 11.09.2006.

78. TST-E-RR-416.933/98.3, Estado do Ceará - Extinta Companhia Estadual de Desenvolvimento da Aquicultura e da Pesca x Luiz Alexandre da Silva e outros, Relator Milton de Moura França, 19.09.2006.

79. TST-E-ED-RR-610.914/99.3, Mercedez-Benz do Brasil S.A. x Maria Cecília Nogueira de Andrade, Redator Designado Milton de Moura França, 12.12.2006.

80. TST-E-RR-744.959/2001.0, Philip Morris Brasil S.A. x Luiz dos Santos Martins, Ministra Relatora Maria Cristina Irigoyen Peduzzi, 25.09.2006.

81. TST-E-RR-474198/1998.6, Finame - Agência Especial de Financiamento Industrial x José Asdrubal Bezerra de Souza, Ministro Relator Carlos Alberto Reis de Paula, 21.11.2006.

82. TST-E-RR-639.504/2000.6, Companhia Siderúrgica Belgo Mineira x Expedito Vitor da Luz e outros, Ministra Relatora Maria Cristina Irigoyen Peduzzi, 12.12.2006.

\section{7}

83. TST-E-RR-642.103/2000.3, Viação Aérea Rio-Grandense S.A. - Varig x Eduardo Rene Saide, Ministra Relatora Maria Cristina Irigoyen Peduzzi, 17.12.2007.

84. TST-E-RR-578.194/99.2, Banco do Estado do Paraná S.A x Robinson Troleis, Redator Designado Milton de Moura França, 10.09.2007.

85. TST-E-ED-RR-466.152/1998.1, Companhia Riograndense de Saneamento Corsan x Celírio Cardoso de Lima, Ministro Relator Vantuil Abdala, 02.04.2007.

86. TST-A-E-RR-40.271/2002-902-02-00.3, Márcio Antônio Leite da Silveira x Sociedade de Educação Jorge Tibiriçá, Ministra Relatora Maria Cristina Irigoyen Peduzzi, 15.10.2007.

87. TST-E-RR-83582/2003-900-02-00.5, Volkswagen do Brasil S.A. x Fidélio Pereira dos Santos e outros, Ministro Relator Aloysio Corrêa da Veiga, 
29.10.2007.

88. TST-E-RR-493583/1998.3, Companhia Riograndense De Saneamento - Corsan x Maria Marques De Oliveira, Ministro Relator Horácio Senna Pires, 17.12.2007.

89. TST-E-RR-48822/2002-900-03-00.9, Fiat Automóveis S.A. x Clayton de Almeida Teodoro, Ministra Relatora Maria de Assis Calsing, 26.11.2007.

90. TST-E-RR-590.225/1999.3, Lauro César Andreoli x Telecomunicações de São Paulo S.A. - Telesp, Ministra Relatora Maria Cristina Irigoyen Peduzzi, 18.06.2007.

91. TST-E-ED-RR-56637/2002-900-10-00.0, Hospital Anchieta Ltda. x Marlúcia Trindade Barbosa, Redator Designado Carlos Alberto Reis de Paula, 16.04.2007.

92. TST-E-ED-RR-1.307/2004-010-03-00.0, Caixa Econômica Federal - CEF x Ademar Geraldo de Almeida e outros, Relator Lelio Bentes Corrêa, 17.09.2007.

\section{8}

93. TST-E-ED-RR-1.046/1998-029-15-00.9, Monte Sereno Agrícola S.A. x Vicente Hernandes Manoel, Ministro Relator Vantuil Abdala, 18.12.2008.

94. TST-E-ED-RR-732.943/2001.3, Ronaldo Costa x Centrais Geradoras do Sul do Brasil S.A. - Gerasul e Empresa Transmissora de Energia Elétrica do Sul do Brasil S.A. - Eletrosul, Redator Designado Vantuil Abdala, 23.06.2008.

95. TST-E-RR-616073/1999.6, Companhia Riograndense de Saneamento - Corsan x Ricardo Moreira de Souza e Magna Engenharia Ltda., Ministra Relatora Maria de Assis Calsing, 06.11.2008.

96. TST-E-ED-RR-530705/1999.8, Ministério Público do Trabalho da 14. ${ }^{a}$ Região x Sindicato dos Trabalhadores em Educação no Estado de Rondônia - Sintero e Estado de Rondônia, Ministra Relatora Maria de Assis Calsing, 20.11.2008.

97. TST-E-RR-699.503/2000.6, Antônio de Oliveira Campos x Banco Itaú S.A. e outro, Ministra Relatora Maria de Assis Calsing, 29.09.2008.

98. TST-E-RR-702300/2000.2, Banestes S.A. - Banco do Estado do Espírito Santo x Rosana Regina Nunes da Silva, Ministra Relatora Maria de Assis Calsing, 15.09.2008.

99. TST-E-RR-583.256/1999.2, Jessie Navajas de Camargo $x$ Instituto Presbiteriano Mackenzie, Ministro Relator Aloysio Corrêa da Veiga, 19.05.2008.

100. TST-E-ED-RR-635669/2000.1, Sérgio Nesi x Banespa S.A. - Serviços Técnicos e Administrativos, Ministra Relatora Maria de Assis Calsing, 25.08.2008.

101. TST-E-ED-RR-622.783/2000.8, Banco Bradesco S.A. x João Alves dos Santos, Ministra Relatora Maria de Assis Calsing, 06.11.2008.

102. TST-E-RR-759.930/2001.7, Companhia Riograndense de Saneamento Corsan x STE - Serviços Técnicos de Engenharia S.A. e Ademar Zilio, Ministro Relator Aloysio Corrêa da Veiga, 30.06.2008.

\section{9}

103. TST- ED-E-RR-491.083/1998.3, Companhia Riograndense de Telecomunicações - CRT x Sirlei Terezinha dos Reis Farias, Ministro Relator Horácio Senna Pires, 21.05.2009.

104. TST-E-ED-RR-672050/2000.1, Sindicato dos Empregados em Estabelecimentos Bancários do Sul Fluminense x Banco Itaú S.A., Juiz 


\begin{tabular}{|c|}
\hline Convocado Relator Douglas Alencar Rodrigues, 24.09.2009. \\
\hline $\begin{array}{l}\text { 105. TST-E-ED-RR-1231/1999-094-09-00.6, Banco Itaú S.A. x Celso } \\
\text { Carneiro Souto, Juiz Convocado Relator Douglas Alencar Rodrigues, } \\
\text { 22.10.2009. }\end{array}$ \\
\hline $\begin{array}{l}\text { 106. TST-E-ED-ED-ED-RR-81277/2003-900-04-00.8, Fort Dodge Saúde } \\
\text { Animal Ltda. x Glayson de Cerqueira Lima, Ministro Relator João Batista Brito } \\
\text { Pereira, 27.08.2009. }\end{array}$ \\
\hline $\begin{array}{l}\text { 107. TST-E-RR-119/1996-029-15-00.3, Usina São Martinho S.A. x Afonso } \\
\text { Cláudio Balsi, Ministra Relatora Rosa Maria Weber Candiota da Rosa, } \\
\text { 17.09.2009. }\end{array}$ \\
\hline $\begin{array}{l}\text { 108. TST-E-RR-795527/2001.0, Estado de Goiás x Aloysio Cúrcio e outros, } \\
\text { Ministro Relator Lelio Bentes Corrêa, 02.04.2009. }\end{array}$ \\
\hline $\begin{array}{l}\text { 109. TST-E-RR-726.121/2001.1, Telecomunicações de São Paulo S.A. - } \\
\text { Telesp x Geraldo Pedro dos Santos, Ministro Relator Horácio Senna Pires, } \\
\text { 24.09.2009. }\end{array}$ \\
\hline $\begin{array}{l}\text { 110. TST-E-RR-593751/1999.9, Jorlan S.A. - Veículos Automotores } \\
\text { Importação e Comércio x Antônio Olímpio da Natividade, Ministro Relator } \\
\text { Lelio Bentes Corrêa, 10.09.2009. }\end{array}$ \\
\hline $\begin{array}{l}\text { 111. TST-E-RR-723835/2001.0, Companhia Vale do Rio Doce - CVRD x } \\
\text { Luiz Nolasco Crescêncio, Ministro Relator João Batista Brito Pereira, } \\
\text { 24.09.2009. }\end{array}$ \\
\hline $\begin{array}{l}\text { 112. TST-E-ED-RR-620770/2000.0, Souza Cruz S.A. x Vera Lúcia Marques } \\
\text { de Oliveira, Ministro Relator João Batista Brito Pereira, 05.11.2009. }\end{array}$ \\
\hline 2010 \\
\hline $\begin{array}{l}\text { 113. TST-E-RR-22700-91.2005.5.03.0096, União x Hewa Transportes Ltda., } \\
\text { Ministra Relatora Maria Cristina Irigoyen Peduzzi, 25.02.2010. }\end{array}$ \\
\hline $\begin{array}{l}\text { 114. TST-E-ED-RR-688525-54.2000.5.09.5555, Corum Comercial de } \\
\text { Alimentos Ltda. x Marliy Zégio Fiuza de Aquino, Ministro Relator João Batista } \\
\text { Brito Pereira, 04.02.2010. }\end{array}$ \\
\hline $\begin{array}{l}\text { 115. TST-E-RR-21700-48.2005.5.03.0034, Serviço Social da Indústria - } \\
\text { SESI x Elisabete Ferreira Gomes, Ministro Relator Lelio Bentes Corrêa, } \\
\text { 27.05.2010. }\end{array}$ \\
\hline $\begin{array}{l}\text { 116. TST-E-ED-RR-86500-52.2002.5.03.0079, Adalberto Maciel Pereira X } \\
\text { Fundação Comunitária Tricordiana de Educação - Unincor, Ministro Relator } \\
\text { João Batista Brito Pereira, 11.02.2010. }\end{array}$ \\
\hline $\begin{array}{l}\text { 117. TST-E-ED-RR-153400-27.2006.5.12.0014, Denise Soares x Banco do } \\
\text { Estado de Santa Catarina S.A. - BESC, Ministra Relatora Maria Cristina } \\
\text { Irigoyen Peduzzi, 15.04.2010. }\end{array}$ \\
\hline $\begin{array}{l}\text { 118. TST-E-ED-RR-5700-22.2001.5.15.0052, Caldeiraria Rio Grande Ltda.x } \\
\text { Jairo Rodrigues Ferreira, Sopresto - Sociedade Civil de Prestação de Serviços } \\
\text { Quito Ltda. e Fundação de Assistência Social Sinhá Junqueira, Ministra } \\
\text { Relatora Rosa Maria Weber Candiota da Rosa, 27.05.2010. }\end{array}$ \\
\hline $\begin{array}{l}\text { 119. TST-E-ED-RR-706760-37.2000.5.03.5555, Empresa de Transportes e } \\
\text { Trânsito de Belo Horizonte S.A. - BHTRANS x Frederico Augusto Soto, } \\
\text { Ministro Vice-Presidente do TST João Oreste Dalazen, 18.03.2010. }\end{array}$ \\
\hline
\end{tabular}




\section{5}

120. TST-ROAR-1.663/2002-000-03-00.5, Banco do Brasil S.A. x Jorge Brandão Alves Pereira, Allan Kardec Affonso Costa e outros, Ministro Relator Emmanoel Pereira, 19.04.2005.

121. TST-ROAR-636.599/2000.6, Caixa Econômica Federal - CEF x Tânia Valéria dos Santos Mundstock, Ministro Relator Renato de Lacerda Paiva, 09.08.2005.

122. TST-ROAR-55.234/2002-900-06-00.5 e Ação Cautelar no TST-AC60.985/2002-000-00-00.2, A.W. Faber Castell S.A. x José Luciano Tenório, Ministro Relator Renato de Lacerda Paiva, 29.11.2005.

123. TST-ROAR-41.116/2000-000-05-00.0, Banco do Brasil S.A. x Antônio Marcos Souza Santos, Ministro Relator Emmanoel Pereira, 22.02.2005.

124. TST-RXOF e ROAR-12676/2003-000-14-00.0, Estado de Rondônia x Maria Zacarias de Moraes, Ministro Relator José Simpliciano Fontes de F. Fernandes, 17.05.2005.

\section{6}

125. TST-RXOFROAR-109/2002-000-18-00.9, Estado de Goiás x Cezar Zanfranceschi, Ministro Relator José Simpliciano Fontes de F. Fernandes, 13.06.2006.

126. TST-ROAR-550/2005-000-03-00.5, Rosch Administração de Serviços e Informática Ltda x Jane Maria da Silva Queiroz, Ministro Relator Ives Gandra Martins Filho, 24.10.2006.

127. TST-ROAR-99697/2003-900-04-00.0, Expresso Princesa do Sul S/A x Vilmar Nunes de Almeida e outros, Ministro Relator José Simpliciano Fontes de F. Fernandes, 07.02.2006.

128. TST-ROAR-10.008/2004-000-22-00.6, Antônio Feitosa dos Santos Neves x Banco do Estado do Piauí S.A - BEP, Ministro Relator Emmanoel Pereira, 30.05.2006.

129. TST-ROAR-363/2003-000-18-00.8, Banco Beg S.A. x Laurentina Ribeiro Neta Freitas, Ministro Relator Ives Gandra Martins Filho, 07.02.2006.

\section{7}

130. TST-ROAR-1.925/2004-000-15-00.8, Boa Sorte Extratora, Comércio e Transporte de Areia Ltda. x Vicente Mendes de Oliveira, Ministro Relator Renato de Lacerda Paiva, 27.02.2007.

131. TST-ROAR-11772/2002-000-02-00.6, Horácio Ary Trombini x Banco Abn Amro Real S/A e outra, Ministro Relator José Simpliciano Fontes de F. Fernandes, 24.04.2007.

132. TST-ROAR-6.221/2002-909-09-00.3, Márcio Antônio Percicotti x Via

Urbana Empreendimentos Imobiliários S.A. e outros, Ministro Relator Emmanoel Pereira, 06.02.2007.

133. TST-RXOF e ROAR-169.606/2006-900-01-00.3, Universidade Federal do Rio de Janeiro - UFRJ x Artur Schechtma, Ministro Relator Renato de Lacerda Paiva, 12.06.2007.

134. TST-ROAR-4080/2005-000-04-00.3, Lídia Bilous x Porcelana del Porto Ltda., Ministro Relator José Simpliciano Fontes de F. Fernandes, 29.05.2007.

\section{8}

135. TST-ROAR-40.284/2001-000-05-00.9, Sibra $\quad$ Eletrosiderúrgica Brasileira S.A. x Antônio Adilson de Carvalho, Ministro Relator Renato de Lacerda Paiva, 12.08.2008. 
136. TST-ROAR-381/2004-000-10-00.4, Jorge Eustáquio de Abreu $\mathrm{x}$ Companhia Imobiliária de Brasília - Terracap, Ministro Relator Emmanoel Pereira, 08.04.2008.

137. TST-ROAR-3262/2006-000-04-00.8, Viação Belém Novo S.A. x Carlos Augusto Belmonte, Ministro Relator Emmanoel Pereira, 14.10.2008.

138. TST-ROAR-6.223/2002-909-09-00.2, Banco do Brasil S.A. x Edson José de Araújo, Ministro Relator Renato de Lacerda Paiva, 29.04.2008.

139. TST-ROAR-6.146/2005-909-09-00.3, Fospar S.A.- Fertilizantes Fosfatados do Paraná x José Nóbrega de Araújo, Ministro Relator Renato de Lacerda Paiva, 20.05.2008.

\section{9}

140. TST-ROAR-12814/2006-000-02-00.0, Transportadora Trans-Shibata Ltda. x Antônio Carlos Baun, Ministro Relator José Simpliciano Fontes de F. Fernandes, 15.09.2009.

141. TST-ROAR-275/2007-000-04-00.6, Hospital de Clínicas de Porto Alegre x Naidy Aresso Alves, Ministro Relator José Simpliciano Fontes de F. Fernandes, 26.05.2009.

142. TST-RXOFROAR-1.485/2002-000-21-00.4, Município de Coronel Ezequiel x Rita Varela de Medeiros e outros, Ministro Relator Renato de Lacerda Paiva, 09.06.2009.

143. TST-AR-178.394/2007-000-00-00.1, Antônio de Abreu x Pedro Tassinari Filho, Ministro Relator Renato de Lacerda Paiva, 27.10.2009.

144. TST-ROAR-366/2007-000-18-00.5, Denevaldo Ferreira da Hora x Luiz Henrique Meireles Vasconcelos, Ministro Relator Emmanoel Pereira, 26.05.2009.

145. TST-RO-174600-16.2008.5.03.0000, Osmar Camilo do Carmo $\mathrm{x}$ Ministério Público do Trabalho da $3^{\mathrm{a}}$ Região, José Luiz Cavalaro, Fazenda Bela Vista e Cemat - Agro Avícola Iglesias Ltda., Ministro Relator Pedro Paulo Manus, 15.06.2010.

146. TST-RO-491100-57.2008.5.04.0000, Salomão Bursztejn x Patrícia Juliana Pavão Garcia e Taschetto \& Tondolo Ltda., Ministro Relator Pedro Paulo Manus, 01.06.2010.

147. TST-ROAR-69100-45.2006.5.06.0000, Luzia Maria Martins Araújo x Companhia de Desenvolvimento dos Vales do São Francisco e do Parnaíba CODEVASF, Relator Ministro Barros Levenhagen, 13.04.2010.

148. TST-ROAR-115200-92.2008.5.09.0909, Fundo de Pensão Multipatrocinado - Funbep e outros x Adenilson Alexandre da Silva, Relator Ministro Barros Levenhagen, 18.05.2010.

149. TST-ROAR-35800-25.2007.5.18.0000, João Batista Reis $x$ Luiz Henrique Meireles Vasconcelos, Ministro Relator Alberto Luiz Bresciani de Fontan Pereira, 01.06.2010. 